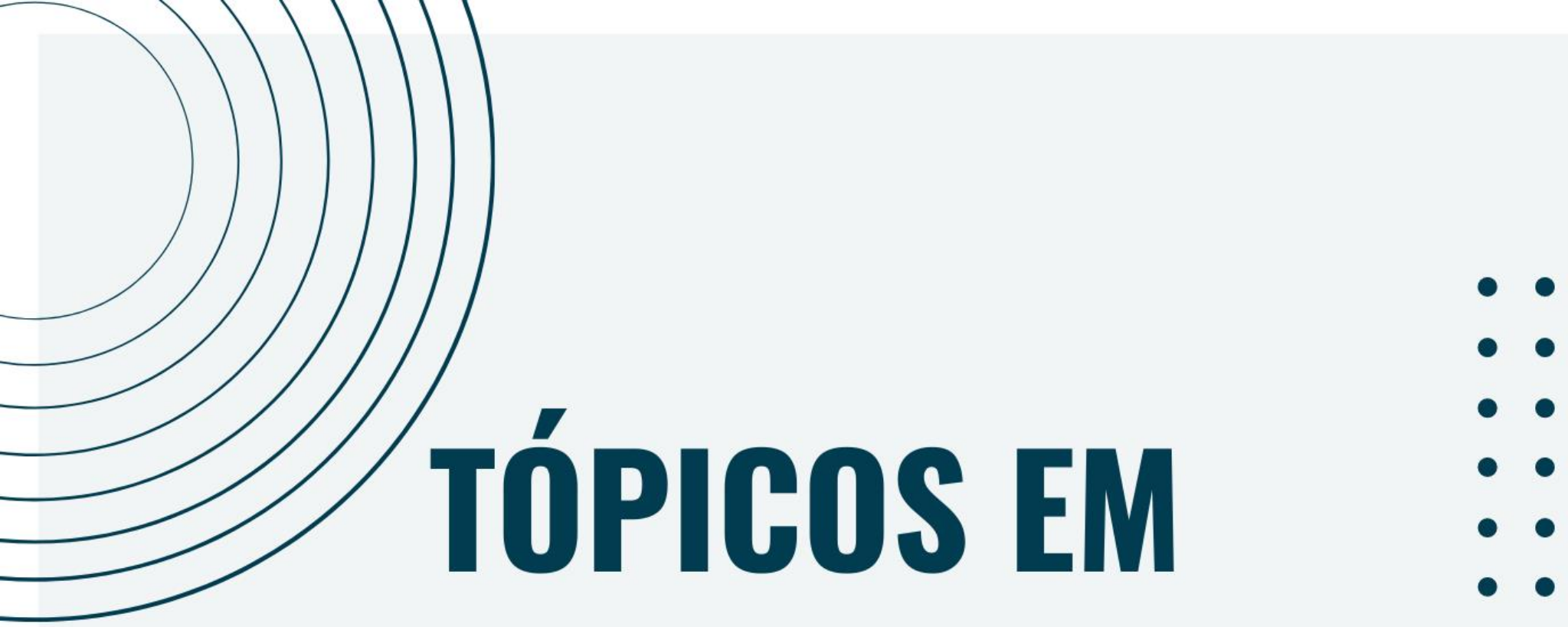

\title{
CIÊNCIAS AGRÁRIAS
}

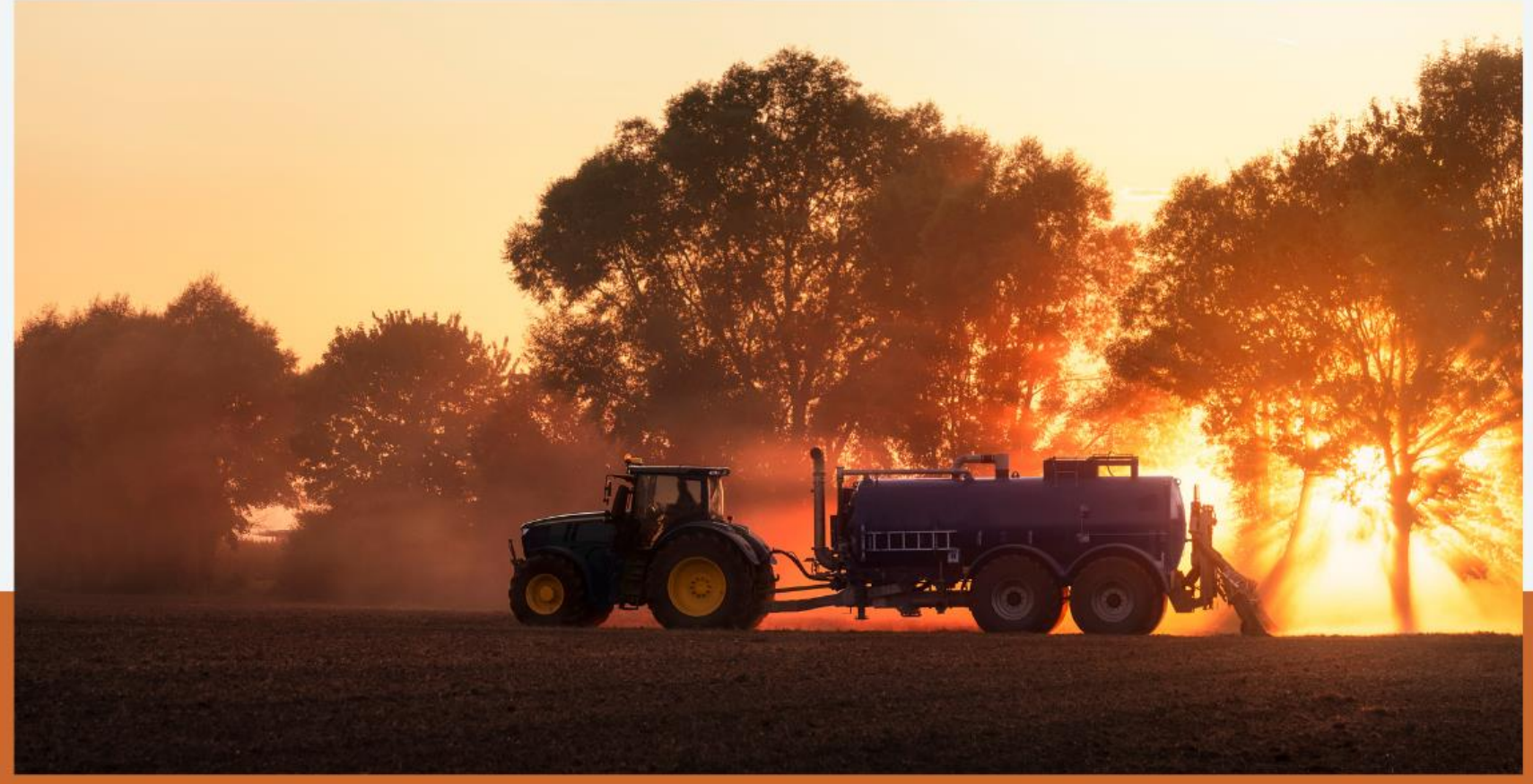

Organizador

Ezequiel Redin
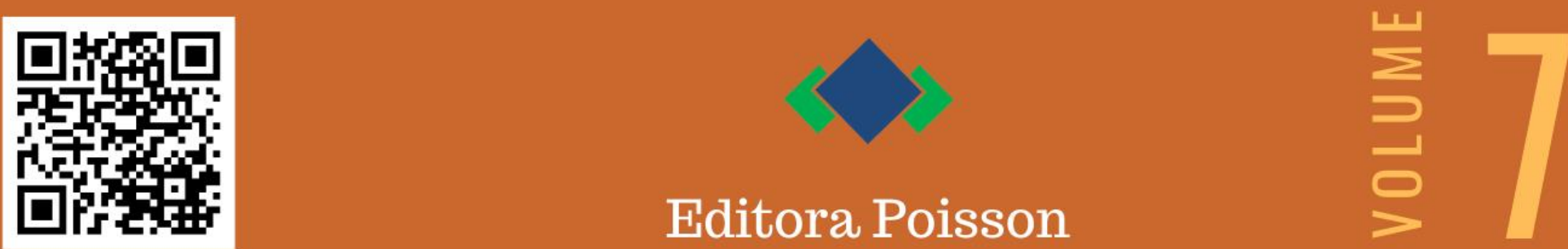
Ezequiel Redin

(Organizador)

\section{Tópicos em Ciências Agrárias Volume 7}

1a Edição

Belo Horizonte

Poisson

2020 
Editor Chefe: Dr. Darly Fernando Andrade

\section{Conselho Editorial}

Dr. Antônio Artur de Souza - Universidade Federal de Minas Gerais

Msc. Davilson Eduardo Andrade

Dra. Elizângela de Jesus Oliveira - Universidade Federal do Amazonas

Msc. Fabiane dos Santos

Dr. José Eduardo Ferreira Lopes - Universidade Federal de Uberlândia

Dr. Otaviano Francisco Neves - Pontifícia Universidade Católica de Minas Gerais

Dr. Luiz Cláudio de Lima - Universidade FUMEC

Dr. Nelson Ferreira Filho - Faculdades Kennedy

Ms. Valdiney Alves de Oliveira - Universidade Federal de Uberlândia

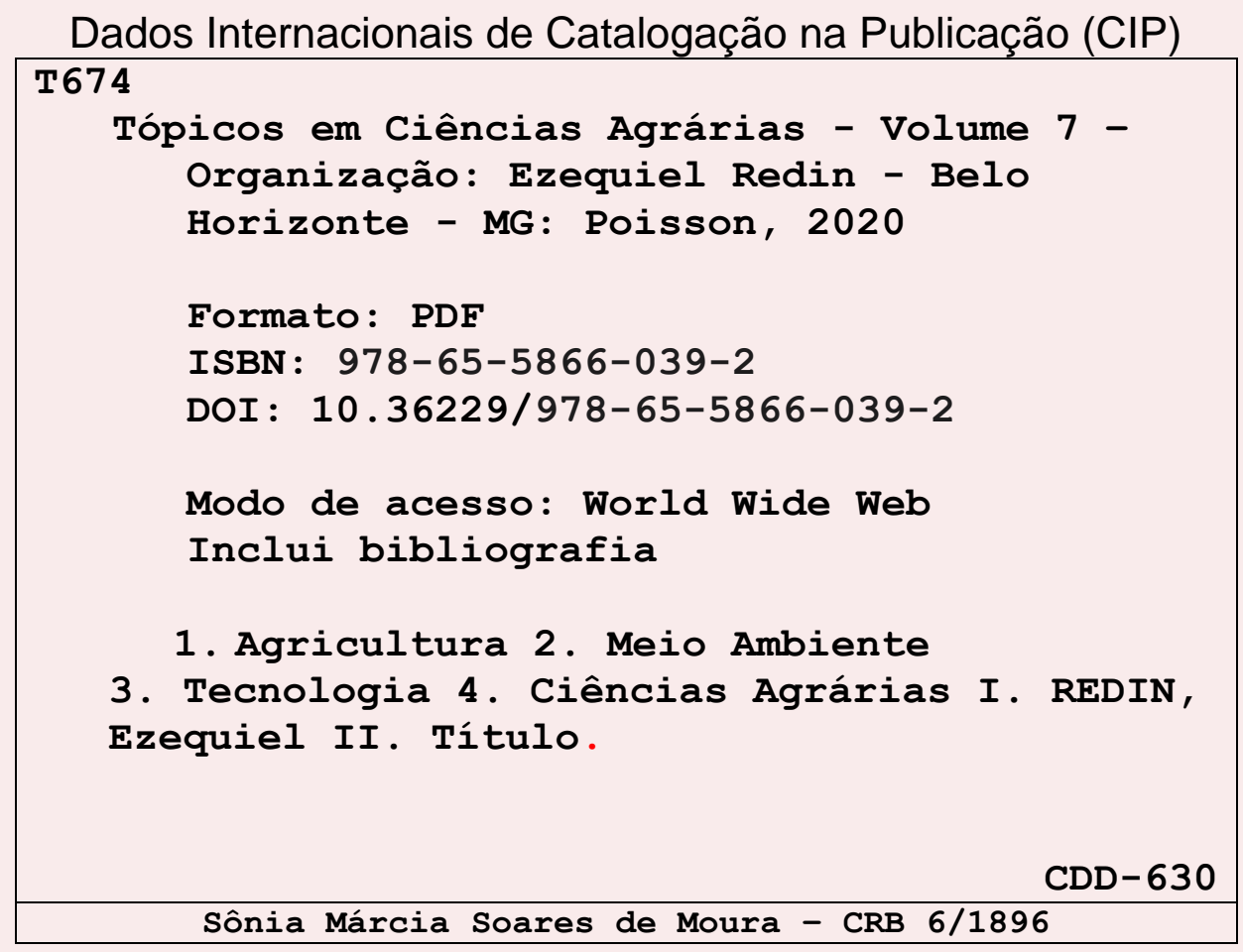

O conteúdo dos artigos e seus dados em sua forma, correção e confiabilidade são de responsabilidade exclusiva dos seus respectivos autores

$\underline{\text { www.poisson.com.br }}$

contato@poisson.com.br 


\section{SUMÁRIO}

Capítulo 1: Matéria seca, produtividade e uso da água pelo milho em diferentes densidades de plantio

Ricardo Barbosa Gomes de Morais, Lekson Rodrigues Santos, Jeferson Miguel Dias Santos, Marcelo Augusto da Silva Soares, Cicero Teixeira Silva Costa, Allan Hemerson de Moura

DOI: 10.36229/978-65-5866-039-2.CAP.01

Capítulo 2: Efeito de bactérias promotoras de crescimento vegetal sobre a produção de tomate (Solanum Lycopersicum) na presença de Fusarium oxysporum f.sp. lycopersici

Jose Jahir Morales Murillo, Alejandro Echeverry Toro, Luisa Vásquez Ramírez, Yacenia Morillo Coronado, Nelson Ceballos Aguirre

DOI: 10.36229/978-65-5866-039-2.CAP.02

Capítulo 3: Alterações do pH e acidez trocável em solos naturais e antropizados da cidade de Cajapió-MA 20

Jonas Juliermerson Silva Otaviano, Naama Aguiar Moreira, Rennan da Silva de Sousa Moreira, Ana Paula Brito de Sousa, Jorge Diniz de Oliveira

DOI: $10.36229 / 978-65-5866-039-2 . C A P .03$

Capítulo 4: Diagnose visual de deficiências nutricionais em Physalis peruviana L...... 25

Filipe Bittencourt Machado de Souza, Ana Izabella Freire, Ariana Mota Pereira, Renata Ranielly Pedroza Cruz, Ivan de Paiva Barbosa, Viviane Amaral Toledo Coelho

DOI: $10.36229 / 978-65-5866-039-2 . C A P .04$

Capítulo 5: Trocas gasosas em capim mombaça (Panicum maximum Jaq. cv Mombaça) cultivado sob diferentes níveis de depleção de água no solo 31

Diego Brandão, Sergio Nascimento Duarte, Pedro Ramualyson Fernandes Sampaio, Timóteo Herculino da Silva Barros, Osvaldo Nogueira de Sousa Neto, Alan Bernard Oliveira de Sousa

DOI: $10.36229 / 978-65-5866-039-2 . C A P .05$

Capítulo 6: Avaliação in vitro de extrato de própolis no controle de biofilmes microbianos. 36

Antonio André Cavalcante Nunes, Johnathan Erick Fernandes Gameleira, Marcelino Gevilbergue Viana, Michelle de Oliveira Guimarães Brasil

DOI: $10.36229 / 978-65-5866-039-2 . C A P .06$ 


\section{SUMÁRIO}

Capítulo 7: Características físico-químicas de frutos de Noni 46

Rita de Cássia Santos Nunes, Fabrício Vieira Dutra, Mariana Costa Rampazzo, Gabriela Leite Silva, Adriana Dias Cardoso, Alcebíades Rebouças São José

DOI: 10.36229/978-65-5866-039-2.CAP.07

Capítulo 8: Estudo da capacidade antirradicalar do extrato etanólico do eucalipto .. 51

Amanda Lima Cunha, Monizy da Costa Silva, Aldenir Feitosa dos Santos, João Victor Laurindo dos Santos, Ingrid Sofia Vieira de Melo, Karla T. M. Gollner-Reis

DOI: 10.36229/978-65-5866-039-2.CAP.08

Capítulo 9: Atividade fungitóxica de extratos vegetais de plantas nativas do bioma Caatinga sobre colletotrichum musae, agente causal da antracnose em banana 56

Ranoel José de Sousa Gonçalves, Maria Zilderlania Alves, Maria Lúcia da Silva Cordeiro, Isabella da Rocha Silva, Eudocia Carla de Araújo, Lucas Rodolfo Inácio da Silva, José Renato Guimarães

DOI: 10.36229/978-65-5866-039-2.CAP.09

Capítulo 10: Otimização do teor de lignina de resíduos de baru para a produção de biocarvão 61

Yara Karla de Salles Nemet, Magale Karine Diel Rambo, Fábio Eduardo Nemet, Érica Priulli, Polyana Morais de Melo, Patricia Oliveira Vellano

DOI: 10.36229/978-65-5866-039-2.CAP.10

Capítulo 11: Potencial bioeconômico de Euterpe oleracea Mart.: Respostas térmicas do caule do açaizeiro testado por espectroscopia infravermelho 69

Cezar Dias Cardoso Junior, Bruno Monteiro Balboni, Alessandra Silva Batista, Rafael de Aguiar Rodrigues, Diego Lima Aguiar, Lucieta Guerreiro Martorano

DOI: 10.36229/978-65-5866-039-2.CAP.11

Capítulo 12: Uso de wetland com a macrófita aquática Salvinia sp no tratamento do efluente de parboilização de arroz

Edmilson Cesar Bortoletto, Felipe de Souza Silva, João Vitor Costa de Almeida

DoI: 10.36229/978-65-5866-039-2.CAP.12

Capítulo 13: Respuesta física y fisiológica del cultivo de morera (Morus alba) a dos condiciones de altitud en la cuenca del Rio Guacha en mediaciones del municipio de Belén (Boyacá) y el Encino (Santander) en Colombia.

Henry Alexander Reyes Martinez, Fabio Emilio Forero Ulloa, Marcelo Marinho Viana

DOI: $10.36229 / 978-65-5866-039-2 . C A P .13$ 


\section{SUMÁRIO}

Capítulo 14: Tolerância à salinidade, crescimento e produção de manjericão sobre cultivo hidropônico.

Luana Nascimento da Silva, Odeane Viriato Maia, Luana da Silva Guedes, Luiz Paulo Campos Patrício DOI: 10.36229/978-65-5866-039-2.CAP.14

Autores. 


\title{
Capítulo 1
}

\section{Matéria seca, produtividade e uso da água pelo milho em diferentes densidades de plantio}

\author{
Ricardo Barbosa Gomes de Morais \\ Lekson Rodrigues Santos \\ Jeferson Miguel Dias Santos \\ Marcelo Augusto da Silva Soares \\ Cicero Teixeira Silva Costa \\ Allan Hemerson de Moura
}

Resumo: 0 milho (Zea mays L.) é o cereal mais produzido no mundo, sendo utilizado, principalmente, na alimentação humana e animal. No Nordeste brasileiro a má distribuição das chuvas é o fator que mais influencia no rendimento das culturas agrícolas, o que faz necessário aumentar a eficiência no uso da água (EUA) pelas plantas. Juntamente, a densidade de plantio adequada é relevante para a elevação do rendimento da cultura, uma vez que para reduzir o risco das plantas sofrerem estresse hídrico os produtores usam densidades com menor número de plantas por área. Objetivou-se avaliar a densidade de cultivo que proporcione a melhor produção de matéria seca e de grãos por área, com a maior EUA pelas plantas. 0 trabalho foi conduzido na região de Rio Largo - AL, com quatro densidades de plantio (D1 125.000 plantas ha-1, D2 - 87.500 plantas ha-1, D3 - 50.000 plantas ha-1 e D4 - 37.500 plantas ha-1). As variáveis agrometeorológicas foram obtidas numa estação automática de aquisição de dados localizada ao lado do experimento. A precipitação pluvial total foi de $679 \mathrm{~mm}$, dividida em $199 \mathrm{~mm}$ na fase inicial, 149 $\mathrm{mm}$ na fase de crescimento, $86 \mathrm{~mm}$ na fase intermediária e $245 \mathrm{~mm}$ na fase final de desenvolvimento da cultura. A ETr durante o cultivo acumulou $429 \mathrm{~mm}$, que variaram de 0,8 a 6,0 mm, tendo seu valor máximo durante a fase intermediária. A produtividade de matéria seca total foi $20,65 \mathrm{t}$ ha $-1,19,71 \mathrm{t}$ ha $-1,13,07 \mathrm{t}$ ha-1 e 11,58 t ha -1, em D1, D2, D3 e D4, respectivamente. 0 rendimento agrícola da cultura, variou devido as densidades de plantio, resultando em 4,69, 5,98, 6,41 e 5,89 t ha-1, em D1, D2, D3 e D4, respectivamente. A eficiência no uso da água pela cultura para a produção de matéria seca variou de 2,70 kg m-3 e 4,81 kg m-3, em D4 e D1, respectivamente. Para a produção de grãos os resultados obtidos foram de 1,09 kg m-3 (D1) a 1,49 kg m-3 (D3). As densidades de 125.000 (D1) e 87.000 (D2) plantas ha-1 obtiveram as maiores produtividades de matéria seca (20,65 e 19,71 t ha-1) e eficiência no uso da água (4,81 e 4,59 kg m-3), respectivamente. Para a produtividade de grãos os tratamentos mais eficientes no uso da água foram D3 e D2, que obtiveram, simultaneamente, rendimento agrícola de 6,41 e 5,98 t ha-1.

Palavras-chave: disponibilidade hídrica, evapotranspiração real, chuva 


\section{INTRODUÇ̃̃O}

Devido a sua grande importância socioeconômica, o milho (Zea mays L.) é o cereal mais produzido no mundo. É utilizado, principalmente, na alimentação humana e animal, onde será consumido na forma de grãos, silagem ou transformado em ração (DEMARCHI, 2011). 0 11ํo levantamento da CONAB (2015), aponta que na safra 2014/2015 o Brasil apresenta uma produção total de 84,3 milhões de toneladas e produtividade média de 5,37 t ha-1, em que a Região Nordeste brasileira produziu 6,5 milhões de toneladas do grão, com 2,41 t ha-1 de produtividade média. No Nordeste, o Estado de Alagoas encontrasse em sétimo colocado na produção do grão (27,8 mil toneladas), alcançando uma produtividade média de 1,0 t ha-1 .

As condições edafoclimáticas são determinantes para o rendimento das culturas agrícolas. No semiárido Nordestino, a maioria dos cultivos são feitos sob regime de sequeiro, com isso, a precipitação pluvial é o fator que mais afeta a produção (KUNZ et al., 2007), sobretudo, por causa da irregularidade na distribuição das chuvas durante o ciclo agrícola da cultura, levando ao mal desenvolvimento das plantas e o déficit produtivo (SOUZA, 1991). Tornando necessário aumentar a eficiência no uso da água (EUA) pela cultura. A EUA é um índice de grande importância para a administração do crescimento e produtividade de culturas agrícolas (TEODORO, 2011), determinado através da relação entre o rendimento ou acumulo de matéria seca da cultura e a quantidade de água consumida para produzi-la (SANDER et al., 2004).

SCHWEITZER (2010) menciona que outro fator relevante para a elevação do rendimento da cultura é a utilização da densidades de plantio adequadas. Para reduzir o risco das plantas sofrerem estresse hídrico, é muito comum que produtores artesanais usem densidades abaixo de 50.000 plantas por hectare, o que, de acordo com SANGOI, et al., 2010, promove o aumento da produção de grãos por indivíduo e reduz a produção por área.

O presente trabalho objetivou determinar a densidade de cultivo que proporcione a melhor produção de matéria seca e de grãos por área, com a maior EUA pelas plantas.

\section{METODOLOGIA}

O estudo foi conduzido no campo experimental do Centro de Ciências Agrárias da Universidade Federal de Alagoas (CECA/UFAL), localizado no município de Rio Largo - AL (09²8’ 02” S; 3549’ 43” W; 127m). 0 clima classificasse como quente e úmido $\left(B_{1}\right)$ megatérmico $\left(A^{\prime}\right)$, com deficiência de água moderada no verão (s) e grande excesso de água no inverno $\left(w_{2}\right)$ (THORNTHWAITE \& MATHER, 1995). O solo é classificado em Latossolo Amarelo coeso argissólico, de textura média/argilosa e declividade inferior a $2 \%$ (CARVALHO, 2003).

O delineamento experimental foi o de blocos casualizados, com quatro repetições. 0 plantio foi realizado através de cultivo mínimo, no dia 08 de Julho de 2013, com espaçamento de 0,8 m de entrelinhas. Os tratamentos constaram de quatro densidades de plantio, 125.000 plantas ha-1 $\left(\mathrm{D}_{1}\right), 87.500$ plantas ha-1 $^{-1}$ $\left(D_{2}\right), 50.000$ plantas ha-1 $\left(D_{3}\right)$ e 37.500 plantas ha-1 $\left(D_{4}\right)$. Na adubação de fundação foi aplicado 30, 60 e 80 kg ha-1 de $\mathrm{N}, \mathrm{P}_{2} \mathrm{O}_{5}$ e $\mathrm{K}_{2} \mathrm{O}$, respectivamente, e na adubação de cobertura utilizou-se $150 \mathrm{Kg}$ de $\mathrm{N}^{-1}$, na forma de uréia. No dia 19 de setembro de 2013, iniciou-se o manejo da irrigação, com base na $\mathrm{ET}_{0}$ diária. Utilizou-se sistema de gotejamento com fitas de $16 \mathrm{~mm}$, espaçadas a $0,8 \mathrm{~m}$ e gotejadores a cada $0,2 \mathrm{~m}$, vazão nominal de 1,6 l h-1, aplicando lâminas de $20 \mathrm{~mm}$ com turno de rega de dois dias.

As variáveis meteorológicas utilizadas, como: precipitação pluvial, e $\mathrm{ET}_{0}$ foram cedidas pelo Laboratório de Agrometeorologia e Radiometria Solar da Universidade Federal de Alagoas (LARAS - UFAL). A ET 0 foi determinada pelo método de Penman Monteith (ALLEN et al., 2005) e a evapotranspiração real da cultura $\left(E_{r}\right.$ ) foi obtida através do cálculo do balanço hídrico de THORNTWAITE \& MATHER (1957). A partir de quando as plantas atingiram o estádio fenológico $\mathrm{V}_{4}$ até a maturidade fisiológica, foram coletadas, semanalmente, as amostragens de material, que foi secado em estufa de ventilação forçada, a $60 \stackrel{\circ}{\circ}$ por 72 horas. A produtividade foi apurada pelo rendimento de grãos em $9 \mathrm{~m}$ lineares, quando as plantas atingiram a maturidade fisiológica. 


\section{RESULTADOS E DISCUSSÃO}

A precipitação pluvial total foi de $679 \mathrm{~mm}$, em que $199 \mathrm{~mm}$ ocorreu na fase inicial, $149 \mathrm{~mm}$ na fase de crescimento, $86 \mathrm{~mm}$ na fase intermediária e $245 \mathrm{~mm}$ na fase final de desenvolvimento da cultura. 0 total acumulado esteve acima de $500 \mathrm{~mm}$, quantidade mínima para a obtenção da produtividade máxima da cultura, mencionada por DOOREMBOS \& KASSAN (1979). Devido à má distribuição hídrica das chuvas tornou-se necessário fazer uso da irrigação entre 19 de setembro e 06 de novembro de 2013, evitando a deficiência hídrica durante e após o embonecamento, fase de maior exigência hídrica da cultura, na qual o estresse pode reduzir de 40 a 50\% a produtividade, de acordo com ANDRADE et al. (2006).

$\mathrm{A} \mathrm{ET}_{\mathrm{r}}$ durante o cultivo acumulou $429 \mathrm{~mm}$, que variaram de 0,8 a 6,0 mm, tendo seu valor máximo durante a fase intermediária. Na fase de crescimento a redução da $\mathrm{ET}_{\mathrm{r}}$ foi ocasionada pelo estresse hídrico (ALLEN et al., 1998) (Figura 1).

Figura 1. Precipitação pluvial, irrigação e evapotranspiração real (ET $\mathrm{r}$ ) da cultura, em cada fase do ciclo de desenvolvimento de milho, em relação aos dias após o plantio (DAP).

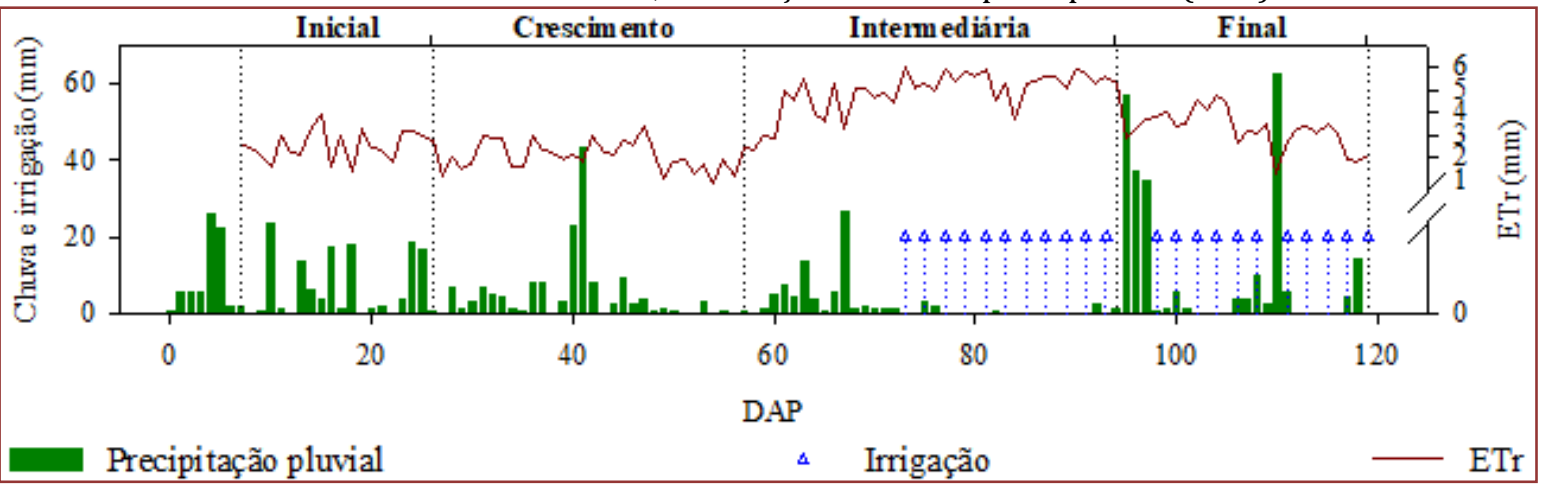

A matéria seca total acumulada foi 20,65 $\mathrm{t} \mathrm{ha}^{-1}, 19,71 \mathrm{t}$ ha ${ }^{-1}, 13,07 \mathrm{t} \mathrm{ha}^{-1}$ e 11,58 $\mathrm{t}$ ha ${ }^{-1}$, em $\mathrm{D}_{1}, \mathrm{D}_{2}, \mathrm{D}_{3}$ e $\mathrm{D}_{4}$, respectivamente, variando 44\% entre a MS máxima e mínima observada. Em torno de 60 DAE, com 423 mm de precipitação pluvial acumulada, a partição de MS alcançou os valores máximos nas folhas, que variou de $1,95 \mathrm{t} \mathrm{ha}^{-1}\left(\mathrm{D}_{4}\right)$ a $4,18 \mathrm{t} \mathrm{ha}^{-1}\left(\mathrm{D}_{1}\right), 53 \%$ de diferença máxima entre os tratamentos, e no colmo, variando entre 3,19 t ha-1 $\left(D_{4}\right)$ e 7,64 t ha-1 $\left(D_{1}\right)$, 58\% de diferença máxima. A partir daí a MS de folhas e colmo iniciou a reduzir, devido a partição dos fotoassimilados ser dirigida, principalmente à formação das espigas (ACEVEDO et al., 1971). A MS máxima das espigas foi obtida no final do ciclo da cultura, aos 102 DAE, devido a maturação fisiológica das plantas, com resultados entre 8,03 t ha-1 $\left(D_{4}\right)$ e $12,43 t$ ha-1 $^{-1}\left(D_{1}\right)$, diferença de 54\% entre os valores máximos e mínimos observados (Figura 2).

Figura 2. Partição de matéria seca média (MS, t ha-1) para folhas, colmo e espiga, em função dos dias após a emergência (DAE), nos tratamentos D1, D2, D3 e D4.

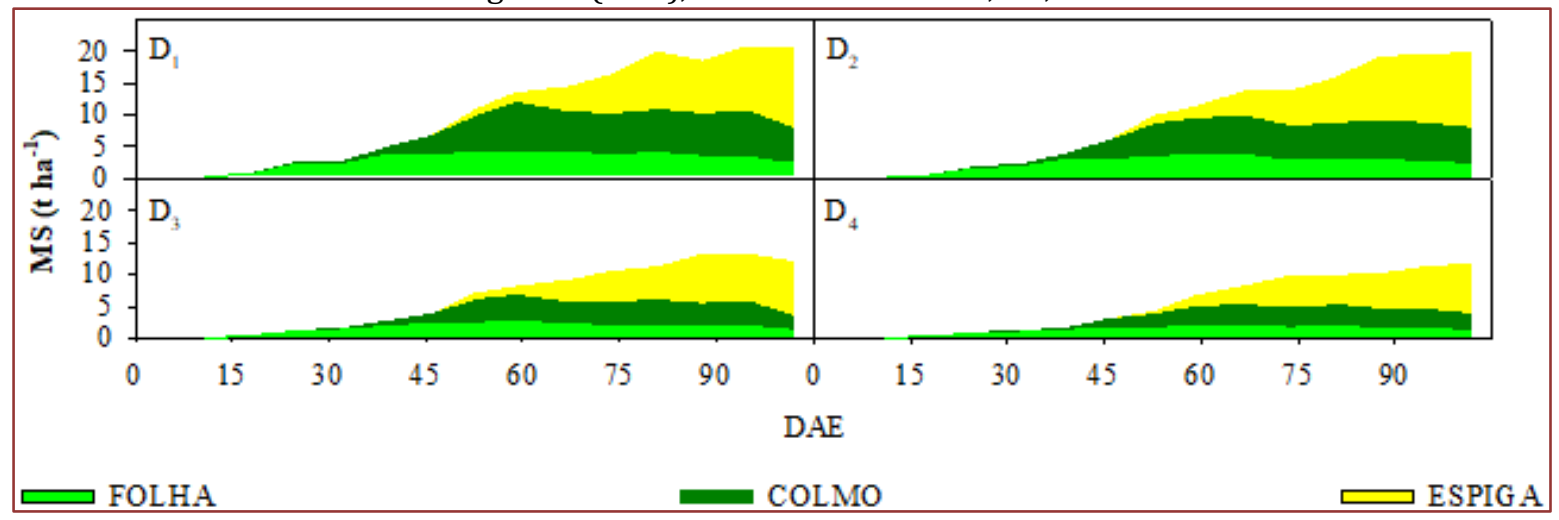


A produtividade de grãos apresentou diferença máxima de $27 \%$ entre as densidades, o tratamento $\mathrm{D}_{1}$ obteve 4,69 t ha-1, devido a forte competição intraespecífica na área, ocasionada pelo super-adensamento da população, prejudicando a produção (SANGOI, L., 2000). Em $\mathrm{D}_{2}$ a produtividade aumentou 27,5\% em relação a $\mathrm{D}_{1}$, graças a redução da competição entre as plantas, gerando o maior número de grãos por área (CALONEGO, et al., 2011) atingindo 5,98 t ha-1. A maior produtividade foi alcançada por $\mathrm{D}_{3}\left(6,41 \mathrm{t} \mathrm{ha}^{-1}\right)$, que superou $\mathrm{D}_{4}\left(5,89 \mathrm{t} \mathrm{ha}^{-1}\right)$ com $8 \%$ de diferença, por causa do melhor aproveitamento de área e melhor eficiência de polinização das flores.

A EUA no rendimento agrícola da cultura diferiu no máximo de $27 \%$ entre os tratamentos, variando de $1,09 \mathrm{~kg} \mathrm{~m}^{-3}\left(D_{1}\right)$ a $1,49 \mathrm{~kg} \mathrm{~m}^{-3}\left(D_{3}\right)$. Valores superiores aos encontrados por Silva (2007), que foi de 0,63 kg $\mathrm{m}^{-3}$ a 1,31 $\mathrm{kg} \mathrm{m}^{-3}$. Na MS total houve diferença de até $34 \%\left(2,70 \mathrm{~kg} \mathrm{~m}^{-3}\right.$ e $4,81 \mathrm{~kg} \mathrm{~m}^{-3}$, em $\mathrm{D}_{4}$ e $\mathrm{D}_{1}$, respectivamente), em que os tratamentos mais adensados apresentaram maior EUA (Figura 3). MEDEIROS (2009) encontrou valores próximos aos observados, avaliando quatro épocas de plantio, obtendo EUA para matéria seca total entre $3,92 \mathrm{~kg} \mathrm{~m}^{-3}$ e 4,50 $\mathrm{kg} \mathrm{m}^{-3}$.

Figura 3: Produtividades de matéria seca total (MS, tha-1) e de grãos (PRD t ha-1), e eficiência no uso da água para matéria seca total $\left(\mathrm{EUA}_{\mathrm{MS}}, \mathrm{kg} \mathrm{m}^{-3}\right.$ ) e rendimento de grãos (EUAPRD, $\mathrm{kg} \mathrm{m}^{-3}$ ), nas quatro densidades de plantio.

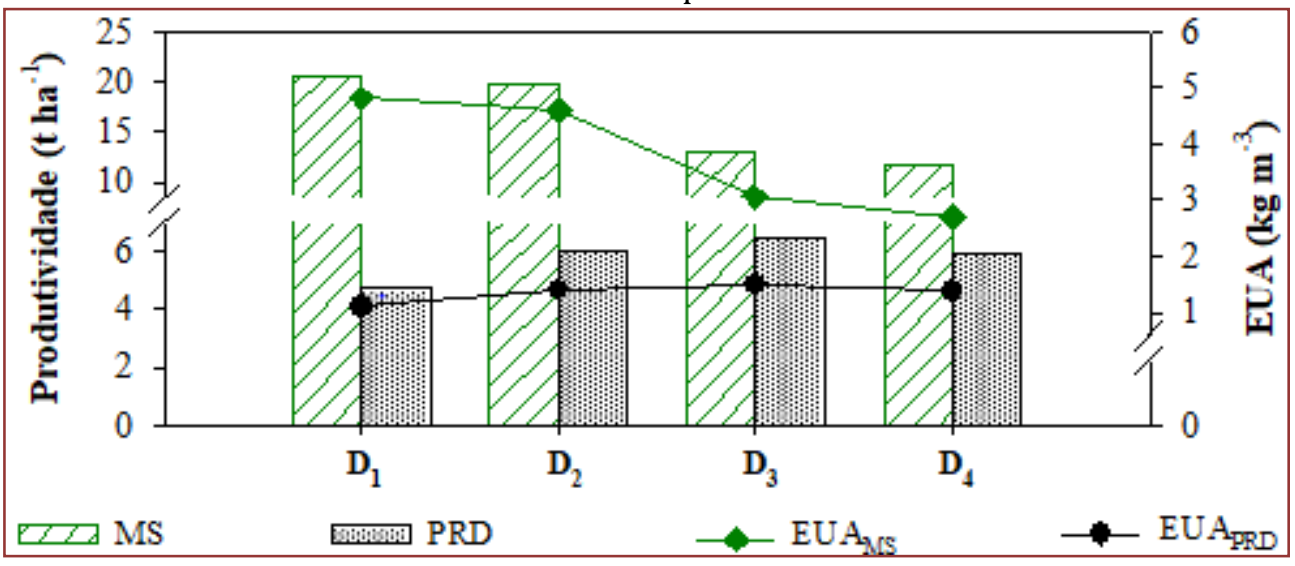

Devido ao adensamento, os tratamentos $\mathrm{D}_{1}$ e $\mathrm{D}_{2}$ foram beneficiados proporcionando o maior acumulo de matéria seca por área, gerando aumento da EUA, com isso, ao relacionar à produtividade agrícola, o tratamento $\mathrm{D}_{2}$ apresenta uma boa eficiência tanto na produção de matéria seca por área, quanto em grãos, em função da quantidade de água consumida.

\section{CONCLUSÃO}

As maiores produtividades de matéria seca $(20,65$ e 19,71 t ha-1) e eficiência no uso da água $(4,81$ e 4,59 $\left.\mathrm{kg} \mathrm{m}^{-3}\right)$ foram observadas nas densidades de $125.000\left(\mathrm{D}_{1}\right)$ e $87.000\left(\mathrm{D}_{2}\right)$ plantas ha-1, respectivamente. Para a produtividade de grãos os tratamentos mais eficientes no uso da água foram $\mathrm{D}_{3}$ e $\mathrm{D}_{2}$, que obtiveram, simultaneamente, rendimento agrícola de 6,41 e 5,98 t ha-1.

\section{REFERÊNCIAS}

[1] ACEVEDO, E.; HSIAO, T. S.; HEDERSON, D. W. Immediate and subsequent growth responses of maize leaves to change in water status. Plant Physiology, Rockville, v. 48, p. 631-636, 1971.

[2] ANDRADE, C. L. T.; ALBUQUERQUE, P. E. P.; BRITO, R. A. L.; RESENDE, M. Viabilidade e Manejo da Irrigação da Cultura do Milho. Sete Lagoas - MG: EMBRAPA-CNPMS, 2006. 12 p. (EMBRAPA-CNPMS. Circular Técnica, 85).

[3] ALLEN, R. G.; PEREIRA, L. S.; SMITH, M.; RAES, D.; WRIGHT, J. L. FAO-56 Dual Crop Coefficient Method for Estimating Evaporation from Soil and Application Extensions. Journal of Irrigation and Drainage Engineering, v.131, n.1, p.1-13, 2005. 
[4] ALLEN, R. G.; PEREIRA, L. S.; RAES, D.; SMITH, M. Crop evapotranspiration: Guidelines for computing crop water requirements. Rome: FAO, 1998. 300 p. (FAO. Irrigation and Drainage Paper, 56).

[5] CALONEGO, J. C.; POLETO, L. C.; DOMINGUES, F. N.; TIRITAN, C. S. Produtividade e crescimento de milho em diferentes arranjos de plantas. Dourados, Revista Agrarian; v.4, n.12, p.84-90, 2011.

[6] CARVALHO, O.M.; Classificação e caracterização físico-hídrica de solos de Rio Largo, cultivados com cana-deaçúcar. 2003. P.74 (Dissertação mestrado em agronomia- Rio Largo: Universidade Federal de Alagoas, 2003.

[7] CONAB - COMPANHIA NACIONAL DE ABASTECIMENTO 2015. Acompanhamento da Safra Brasileira de Grãos. v. 2 - Safra 2014/15, n. 11 - Décimo primeiro levantamento, Brasília, p. 1-101, agosto 2015. Disponível em: http://www.conab.gov.br/OlalaCMS/uploads/arquivos/15_08_18_10_30_18_boletim_graos_agosto_2015.pdf. Acessado em: 20 de ago. de 2015.

[8] DEMARCHI, M. Análise da conjuntura agropecuária - Safra 2011/12 milho. Secretaria da Agricultura e do Abastecimento Departamento de Economia Rural, Paraná, 2011. Disponível em: http://www.agricultura.pr.gov.br/ar. Acesso em 5 jul. 2015.

[9] DOORENBOS, J.; KASSAM, A. H. Yield response to water. FAO Irrigation and Drainage Paper 33. Rome: Food and Agriculture Organization of United Nations, 1979. 193p.

[10] KUNZ, J. H.; BERGONCI, J. I.; BERGAMASCHI, H.; DALMAGO, G. A.; HECKLER, B. M. M.; COMIRAN, F. Uso da radiação solar pelo milho sob diferentes preparos do solo, espaçamento e disponibilidade hídrica. Pesquisa Agropecuária Brasileira, v.42, p.1511-1520, 2007.

[11] MEDEIROS, R. P. Radiação solar e água em quatro épocas de cultivo de milho de sequeiro (Zea Mays L.), na região agreste de alagoas. Dissertação; (Mestrado em Agronomia) - Universidade Federal de Alagoas, 2009.

[12] SANDER, J. Z., BASTIANSSEN, W. G. M. Review of measured crop water productivity values for irrigated wheat, rice, cotton and maize. Agric. Water Manage. 69 (2), 115-133. 2004.

[13] SANGOI, L.; SILVA, P. R. F.; ARGENTA, G. Estratégias de manejo do arranjo de plantas para aumentar o rendimento de grãos do milho. Lages: Graphel, 2010.67 p.

[14] SANGOI, L. Understanding plant density effects on maize growth and development: an importante issue to maximize grain yield. Ciência Rural, v.31, n.1, p.159-168. 2000.

[15] SOUZA, J. L., PACE, E. L.; Relação hídrica e fenológica de cultura em Rio Largo - AL. Congresso Brasileiro de Meteorologia Meteorologia, Salvador - BA I Novembro de 1990. Aceito para publicação em 29 de abril de 1991.

[16] TEODORO, I. Respostas técnico-econômicas da cana-deaçúcar a níveis de irrigação e adubação nitrogenada. 2011. 82p. Tese (Doutorado em Engenharia Agrícola) Universidade Federal de Campina Grande- PB, 2011.

[17] THORNTHWAITE, C. W. \& MATHER, J. R. The water balance. Centerton, Drexel Institute of Technology, Laboratory of Climatology. 104p. 1995.

[18] THORNTWAITE, C.W. MATHER, J.R. Instructions and tables for computing potencial evapotranspiration and the water balance. Ceterton, NJ: rexel institute of technology-Laboratory, 1957. 311p. (Publications in Climatogy, vol. 10, n.3). 


\section{Capítulo 2}

Efeito de bactérias promotoras de crescimento vegetal sobre a produção de tomate (Solanum Lycopersicum) na presença de Fusarium Oxysporum f.sp. lycopersici

Jose Jahir Morales Murillo

Alejandro Echeverry Toro

Luisa Vásquez Ramírez.

Yacenia Morillo Coronado

Nelson Ceballos Aguirre

Resumo: As bactérias promotoras de crescimento de plantas (PCBs) foram relatadas com um alto potencial para antagonizar doenças de importância econômica na agricultura. Fusarium oxysporum f. sp. Lycopersici em tomate (Solanum lycopersicum L.) é considerado um dos patógenos mais limitantes na produção agricola causando perdas de $60 \%$ no rendimento da cultura. 0 objetivo da pesquisa foi determinar 0 rendimento de tomate sob os efeitos de (PCBs) na presença de Fusarium oxysporum $\mathrm{f}$. sp. Lycopersici. 0 experimento foi realizado na fazenda Montelindo da Universidade de Caldas (Colômbia) localizado em Santagueda no município de Palestina. 0 delineamento experimental utilizado foi o de blocos casualizados em parcelas subdivididas, com arranjo fatorial $9 \mathrm{X} 4 \mathrm{com} 4$ repetições. Os tratamentos consistiram na inoculação de cinco bactérias (GIBI 139, GIBI419, GIBI014, GIB031, GIBI137), dois produtos comerciais (Prophytex ${ }^{\circledR}$ e Benomil ${ }^{\circledR}$ ) e duas testemunhas (plantas com e sem Fusarium oxysporum f. sp. Lycopersici) em quatro genótipos de tomate (IAC 426, IAC 391, Santa Clara e carguero). A unidade experimental consistia em seis plantas por tratamento. No total 120 sementes foram semeadas para cada variedade. As plantas foram estabelecidas em condições semicontroladas e o transplante foi realizado em sacos como solo estéril. Os componentes de rendimento como número de fruto colhido e peso de fruto foram avaliados. A análise estatística dos dados foi feita por meio do pacote estatístico INFOSTAT2016 e SIGMAPLOT 12.5. As cepas bacterianas apresentaram resultados semelhantes aos produtos comerciais. 0 genótipo com o maior número de frutos colhidos foi a IAC426 com o tratamento Benomil.

Palavras chaves: tomate, inoculação, componentes de rendimento. 


\section{INTRODUÇÃO}

0 tomate (Solanum lycopersicum L.) constitui $30 \%$ da produção hortícola do mundo, com aproximadamente 4,4 milhões de hectares plantados e 145.751 .507 toneladas de frutos colhidos até 2010 (Cardona et al, 2016). Segundo FAOSTAT, a produção mundial de tomate em 2017 atingiu 182.301 .395 toneladas com produtividade de $37.600 \mathrm{~kg} \mathrm{ha}^{-1}$ e área colhida de 4.848 .384 ha.

O cultivo do tomate tem uma relação ampla com o uso excessivo de agroquímicos, mas a tendência dos consumidores é preferir alimentos isentos de agrotóxicos, seguros e com alto valor nutricional (De la cruz et al., 2009). Atualmente, a doença mais prejudicial nas plantações intensivas de tomate é a murcha vascular causada por Fusarium oxysporum. f. sp. lycopersici que afeta a zona radicular do tomateiro e progride sistematicamente (Salazar et al., 2011). Esta doença é altamente prejudicial em climas quentes, onde as temperaturas do solo e do ar são altas, favorecendo o desenvolvimento do patógeno. Ocasionalmente, campos inteiros de tomate morrem ou são afetados por graves danos antes da colheita. Portanto, o uso de biofertilizantes é uma estratégia essencial para melhorar a qualidade do solo, aumentar a produtividade e a qualidade dos produtos agrícolas (Johansen et al., 2013). Alguns agentes de biocontrole incluem gêneros de Trichoderma, Penicillium, Gliocladium, Burkholderia, Bacillus, Serratia e muitos outros (Dihazi et al., 2012).

O uso de indutores de resistência, biorreguladores e produtos de origem botânica tem sido estudado para encontrar estratégias eficazes de manejo. Outros métodos utilizados para seu controle são as bactérias promotoras de crescimento de plantas (PCBs) e o uso de variedades resistentes (Gonzales, 2012) que podem durar no mercado sendo tolerantes às diferentes raças de Fusarium oxysporum. f. sp. Lycopersici. As bactérias promotoras do crescimento das plantas são microorganismos amplamente utilizados para esse fim, que interagem com as plantas através de diferentes mecanismos de ação, que incluem a produção de fitohormônios, a fixação biológica de nitrogênio e o biocontrole de patógenos. 0 sucesso de controle desses organismos pelas PCBs é atribuído à atividade sinérgica de diferentes mecanismos de ação, promovendo diretamente o crescimento das plantas e indiretamente a prevenção de doenças (Harman et al., 2004).

O objetivo dessa pesquisa foi avaliar o efeito das bactérias promotoras de crescimento de plantas nos componentes da produção de tomate na presença de Fusarium oxysporum f. sp. lycopersici.

\section{METODOLOGIA}

\subsection{LOCALIZAÇÃO}

O estudo foi realizado na fazenda Montelindo, localizada em Santágueda, município da Palestina (Colômbia) com temperatura média de $22,8^{\circ} \mathrm{C}$, altitude de $1.010 \mathrm{msnm}$, precipitação anual de $2.200 \mathrm{~mm}$ e umidade relativa média de 76\%. A cultura foi semeada em condições semi-controladas.

\subsection{MATERIAL VEGETAL}

Os genótipos IAC426, IAC39, Santa Clara (suscetível a Fusarium oxysporum f. Sp. Lycopersici) e Carguero (resistente) receberam os tratamentos e tiveram os rendimentos avaliados.

\subsubsection{GERMINAÇÃO E PROPAGAÇÃO DE MATERIAL VEGETAL}

No total, 120 sementes foram semeadas para cada variedade em bandejas de 72 células com profundidade de $5 \mathrm{~cm}$. As bandejas foram desinfetadas por imersão em iodo agrícola a 0,5\% (Agrodyne®). A turfa Sphagnum grau 3 foi usada como substrato. As bandejas foram mantidas a $25 \pm 2{ }^{\circ} \mathrm{C}$ e receberam fertirrigação duas vezes por semana. 0 transplante foi realizado 30 dias após a semeadura. As mudas foram transplantadas para sacos com solo estéril e tiveram um período de aclimatação de 14 dias, durante o qual as mudas foram medidas. 


\subsection{PRÁTICAS AGRONÔMICAS}

0 lote foi estabelecido com espaçamento de $1,5 \times 0,5 \mathrm{~m}$. Sacos de $10 \mathrm{~cm}$ de diâmetro x $25 \mathrm{~cm}$ de altura foram usados no cultivo para evitar a contaminação do solo com o fungo. Uma cobertura plástica foi estendida sob os sacos para evitar que Fusarium sp. atingisse o solo por meio da água que escorresse dos sacos. Podas, tutoramento, capinas e irrigação foram feitos durante o cultivo.

\subsection{TRATAMENTOS}

' $\quad$ tto137: GIBI137 Serratia marcescens

- $\quad$ tto31: GIBI031 Gluconacetobacter sacchari

- $\quad$ to419: GIBI419 Burkholderia tropica

- $\quad$ tto14: GIBI014 Gluconacetobacter sacchari

- $\quad$ tto139: GIBI139 Serratia grimesii

" $\quad$ Prophytex®:

Produto comercial que possui uma concentração de (1 X 1012 ufc / litro) da bactéria Bacillus subtilis, a qual é relatada como favorável ao manejo e controle de Fusarium sp. além de induzir o crescimento e aumentar a colheita

- Benomil@: Fungicida sistêmico com ação curativa e preventiva, cujo ingrediente ativo Benomil foi relatado para o manejo de fungos como Fusarium oxysporum f. sp. Lycopersici (Vasquez e Castaño, 2017).

- Testemunha com fusarium oxysporum f. sp. lycopersici

- Testemunha sem fusarium oxysporum f. sp. Lycopersici

Os isolados de bactérias promotoras de crescimento de plantas foram fornecidos pela Coleção de Microorganismos da Universidade Católica de Manizales (CMUCM) (Colômbia), onde foram selecionados de acordo com seu desempenho como inibidores de crescimento (porcentagem de inibição de crescimento - PIC) e a germinação de micro e macro conídios de Fusarium oxysporum f. sp. lycopersici, como produtores de ácido indolacético (AIA), como produtores de acetileno (RA) e como solubilizadores de fosfato (SF).

\subsection{INOCULAÇÃO DE PCBS}

A inoculação foi realizada 15, 45, 60, 75, 90 dias após a semeadura usando $100 \mathrm{ml}$ de uma suspensão de $10^{9} \mathrm{UFC} \mathrm{ml} \mathrm{ml}^{-1}$ de cada PCB. Do total de isolados avaliados nesta fase, os cinco melhores foram selecionados por seu desempenho no índice de eficiência inibitória (> 70\%) contra Fusarium oxysporum f.sp. lycopersici.

\subsubsection{INOCULAÇÃO DE FUSARIUM}

Os esporos de Fusarium oxysporum f. sp. lycopersici foram concedidos pela Coleção de Microorganismos da Universidade de Caldas (Colômbia). Para reativar o isolamento, Fusarium oxysporum f.sp. lycopersici foi cultivado em meio Agar de Dextrose de Batata (PDA) suplementado com raízes de tomate da variedade Sweet obtidas in vitro. Os esporos do fungo foram diluídos até atingir uma concentração de $1 \times 10^{6}$ conídios/mililitro de água destilada estéril. A concentração é ajustada usando um hemocitômetro (Castaño-Zapata, 1998).

\subsection{VARIÁVEIS AVALIADAS}

O Número de frutos colhidos (NFC) e Peso do fruto colhido (PFRC) foram avaliados durante todo período produtivo e quantificados ao final. 


\section{ANALISES ESTATÍSTICA}

Os dados foram submetidos à análise de variância. A comparação das médias foi realizada pelo teste de Tukey, com nível de significância de 0,05. A análise dos dados foi realizada com o programa INFOSTAT2016 e os gráficos realizados no programa SIGMAPLOT 12.5 .

\section{RESULTADOS E DISCUSSÃO}

Os resultados mostraram que as bactérias e os produtos comerciais tiveram efeito significativo quando as plantas foram inoculadas com o fungo Fusarium oxysporum f.sp. lycopersici inibindo seu crescimento e favorecendo o desenvolvimento da cultura.

A análise estatística mostrou diferença significativa no número de frutos (NFC) e peso dos frutos colhidos (PFRC) entre os tratamentos e genótipos de tomate tipo cereja. A interação genótipo x tratamento foi significativa para o PFRC $(\mathrm{p}<0,05)$ (Tabela 1$)$.

Tabela 1. Anova para genótipos de tomate tipo cereja.

\begin{tabular}{|l|c|c|c|}
\hline \multirow{2}{*}{$\begin{array}{c}\text { Genotipo } \\
\text { Nariables }\end{array}$} & \multicolumn{3}{|c|}{ IAC426 vs IAC391 } \\
\cline { 2 - 4 } & GENOTIPO & TRATAMIENTO & INTERACCIÓN \\
\hline NFC & $<0,001$ & $<0,0019$ & 0,1712 \\
\hline PFRC & $<0,002$ & $<0,0001$ & $<0,0002$ \\
\hline
\end{tabular}

Os produtos comerciais utilizados como fungicida Benomil® e o produto à base da cepa bacteriana Bacillus subtilis (Prophytex®) apresentam resultados semelhantes aos resultados das bactérias avaliadas quanto à inibição do crescimento micelial do fungo. Um estudo de Sultana e Ghaffar (2013) relata que o Benomil® utilizado no meio de agar dextrose de batata (PDA) limita o desenvolvimento de Fusarium oxysporum sp. como mostrado neste estudo de campo. A eficácia do Benomil® e de outros fungicidas também foi relatada contra fungos fitopatogênicos (Sultana et al., 2013).

Consequentemente, as bactérias pertencentes ao gênero Bacillus, conforme relatado por Ramyabharathi et al. (2013), que utilizaram a cepa bacteriana Bacillus subtilis EPC016 na formulação líquida, permitiram a indução de proteínas e enzimas de defesa como fenilalanina, catalase e compostos fenólicos no tomate.

Amini e Sidovich (2010) mostraram como o Benomil e vários fungicidas tiveram efeitos curativos na murcha do tomate. Os mais eficazes foram Prochloraz $\AA$ e Bromuconazol $\AA$ in vitro e in vitro vivo, seguido por Benomil® e Carbendazim $®$. 0 tratamento tto419 (Burkholderia tropica) mostrou similaridade na inibição, crescimento e esporulação de Fusarium oxysporum f.sp. lycopersici. Segundo Dihazi (2012) no trabalho realizado sobre o uso de duas bactérias para controle biológico contra Fusarium oxysporum em mudas de palmeira, os gêneros Burkholderia e Bacillus apresentaram atividade antifúngica significativa ( $\mathrm{p}$ $<0,05$ ) inibindo seu crescimento e esporulação no meio PDA.

A bacteria tto014 (Gluconacetobacter sachari) apresentou valores semelhantes aos produtos comerciais (Figura 1). Em testes realizados com bactérias do mesmo gênero, como Gluconacetobacter diazotrophicus PAL5 e Burkholderia tropica MTo-293, observou-se que ambos os microorganismos têm capacidade para colonizar plantas de trigo, sorgo e tomate, sendo bactérias endofíticas não simbióticas e fixadoras de nitrogênio, aumentando a produção de frutos de primeira qualidade (Vidal et al., 2017). 
Figura 1. Número de frutos colhidos (NFC) em tomateiro inoculados com os diferentes produtos comerciais e linhagens de bactérias. Os dados são médias \pm erro padrão. Barras com letras diferentes mostram diferenças estatísticas significativas $(\mathrm{P} \leq 0,05)$.

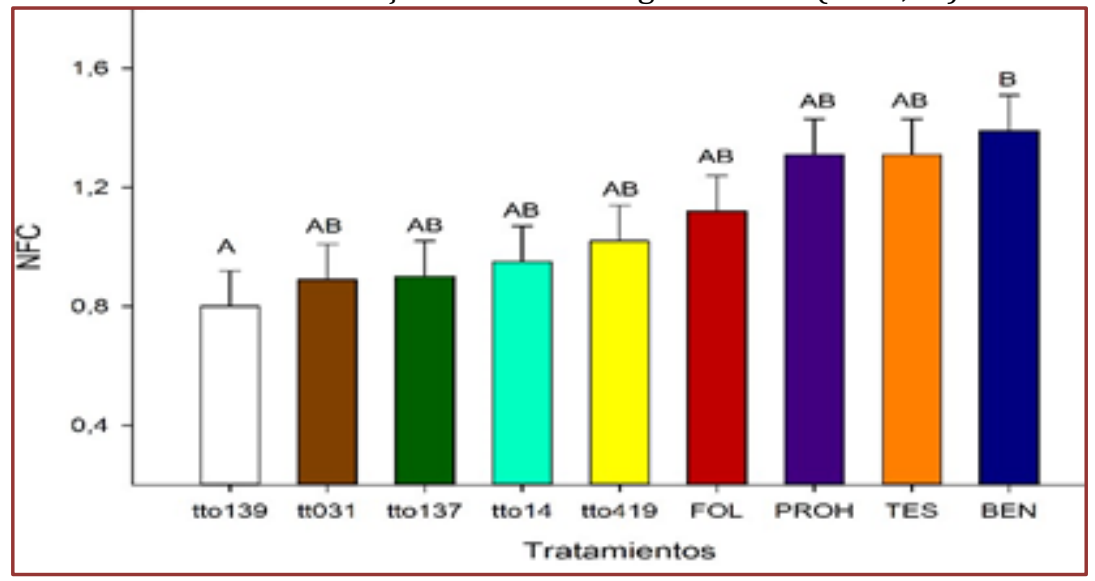

Em relação aos genótipos, houve diferença estatística significante no número de frutos colhidos NFC (p $<0,05)$. 0 genótipo que apresentou os maiores valores da variável mencionada foi o IAC426 (Figura 2). Como no presente estudo, a adesão à IAC426 em um trabalho realizado por Ceballos et al. (2012) mostrou uma relação direta entre frutos de primeira qualidade e quantidade total de frutos colhidos por planta.

Figura 2. Número de frutos colhidos e valores correspondentes a cada genótipo avaliado. Media \pm erro padrão. Barras com letras diferentes mostram diferença estatística significativa $(\mathrm{p} \leq 0,05)$.

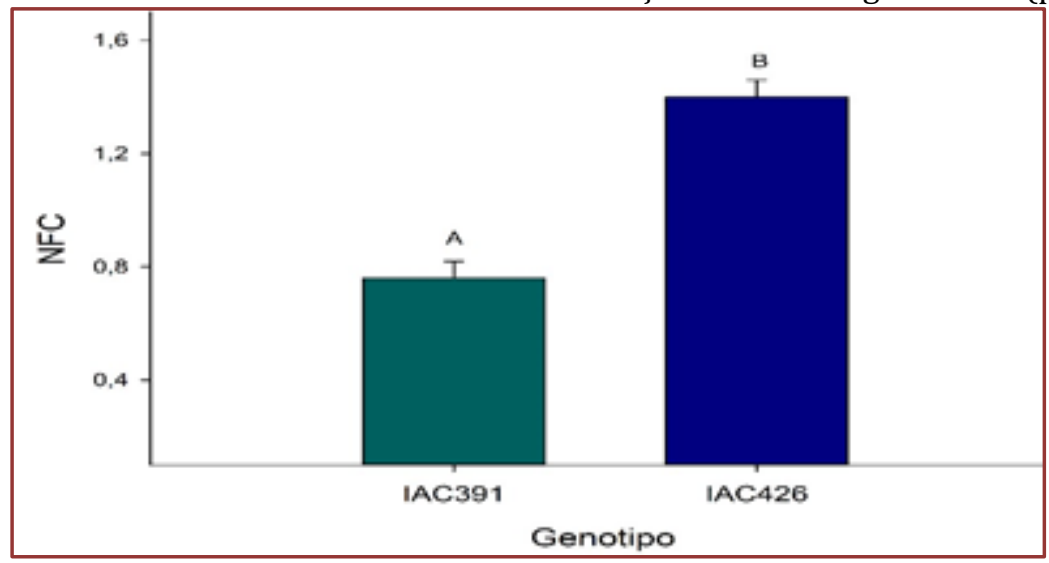

O tratamento que apresentou o maior PFRC foi o Benomil囚, com média de 12,60g (Figura 3.). Nesse caso, não há evidências de um efeito na variável PFRC pelos tratamentos que contêm os isolados das bactérias avaliadas. 0 produto comercial à base de Bacillus subtilis (Prophytex $\AA$ ) tem uma média semelhante de 12,51 g, como demonstrado por Ramyabharathi et al. (2013) em trabalho realizado sobre a indução de proteínas e enzimas de defesa por Bacillus subtilis, onde foi testada a indução de resistência sistêmica contra a murcha vascular. Xu e Sheng (2013), em uma análise filogenética e de sequência gênica indicaram que 22 isolados representativos pertencem a cinco espécies do gênero Bacillus, mostrando promoção de crescimento com $24 \%$ da produção de sideróforos e $85 \%$ da fixação potencial de nitrogênio entre outras propriedades benéficas. 
Figura 3. Peso variável da fruta para cada tratamento. Média \pm erro padrão. Barras com letras diferentes mostram diferença estatística significativa $(p<0,05)$.

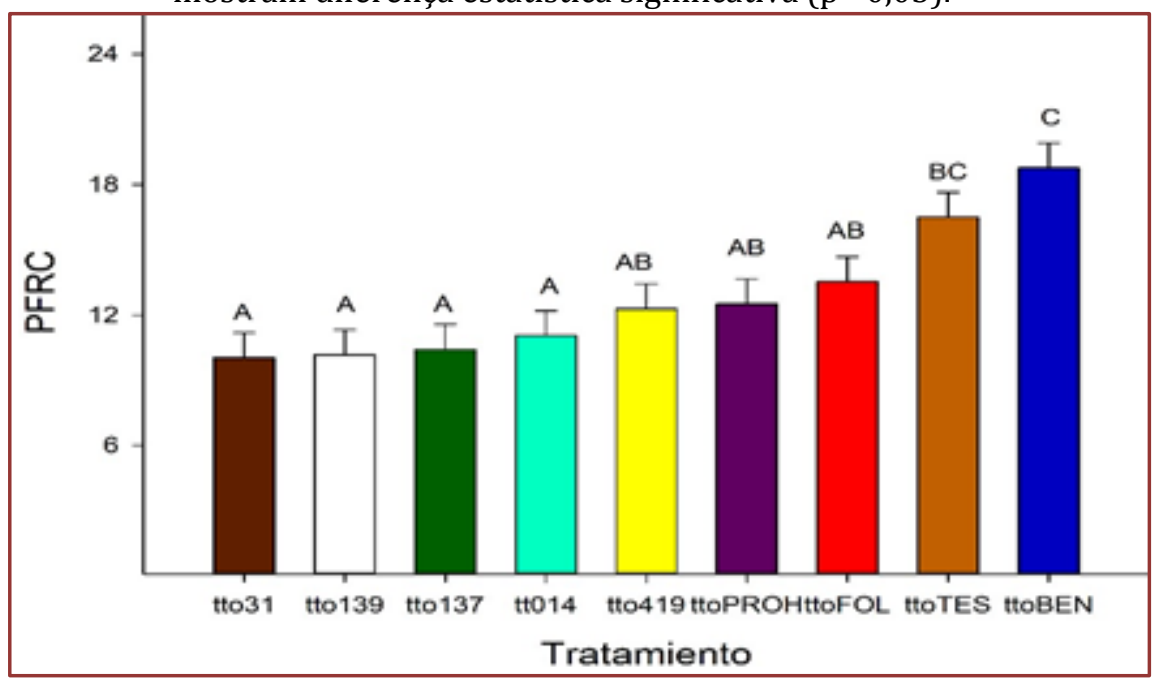

O genótipo IAC426 apresentou os maiores valores de PFRC, enquanto Ceballos et al. (2012) relataram que os genótipos mais promissores nas variáveis de peso e qualidade média dos frutos foram IAC1624, IAC3652 e IAC391 (Gráfico 4).

Gráfico 4. Peso variável do fruto e porcentagens para cada adesão. Média \pm erro padrão. Barras com letras diferentes mostram diferença estatística significativa $(\mathrm{p} \leq 0,05)$.

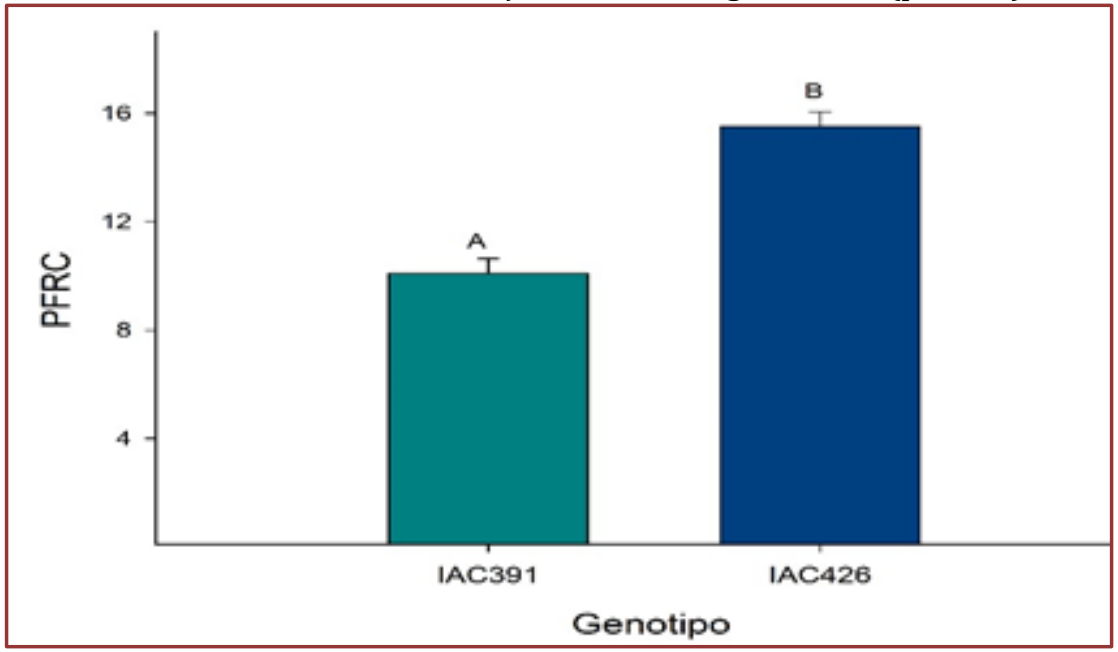

Para a interação do tratamento genótipo x tratamento, o genótipo IAC426 e Benomil® apresentaram os maiores valores de PFRC com uma média de 24,19 g em comparação com o genótipo IAC391 e sua interação com a bactéria tto031, que apresentou os valores mais baixos da análise com uma média de 675 g.

Houve diferença estatística significativa no número de frutos colhidos (NFC) entre os genótipos e tratamentos $(\mathrm{P} \leq 0,05)$ (Tabela 2$)$. 
Tabela 2. Anova para genótipos de tomate do tipo Chonto.

\begin{tabular}{|l|c|c|c|}
\hline \multirow{2}{*}{$\begin{array}{c}\text { Genotipo } \\
\text { Variables }\end{array}$} & \multicolumn{3}{|c|}{ SANTA CLARA vs CARGUERO } \\
\cline { 2 - 4 } & GENOTIPO & TRATAMIENTO & INTERACCIÓN \\
\hline NFC & $<0,001$ & 0,0029 & 0,0704 \\
\hline PFRC & 0,1552 & 0,4969 & 0,4829 \\
\hline
\end{tabular}

Os tratamentos que obtiveram os maiores NFCs foram tto139, tto14 e Prophytex (Figura 5).

Figura 5. Número de frutos colhidos (CNF) e significância dos tratamentos avaliados em campo. Média \pm erro padrão. Barras com letras diferentes mostram diferença estatística significativa $(\mathrm{p}<0,05)$.

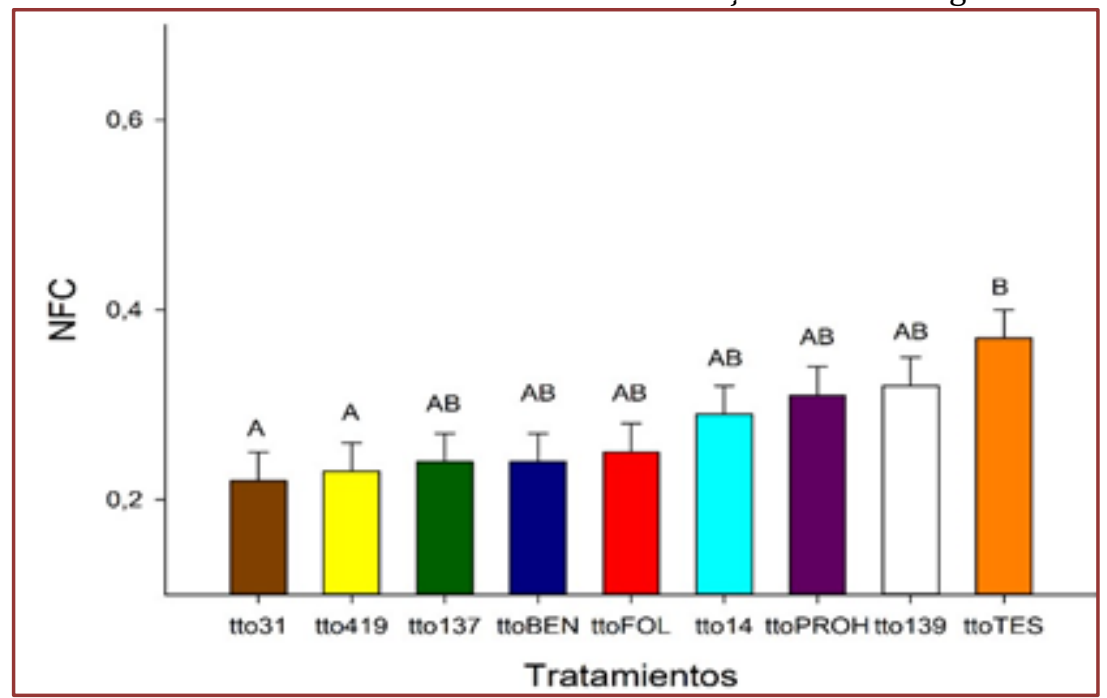

Na variável NFC, ficou evidente que Carguero foi o melhor genótipo, apresentando diferença estatística significante em relação ao genótipo Santa Clara, apresentando um rendimento médio de 0,33 frutos colhidos por planta. 0 genótipo Santa Clara teve média de 0,23 frutos colhidos (Figura 6).

Gráfico 6. Número variável de frutos colhidos para cada genótipo de tomate do tipo Chonto. Média \pm erro padrão. Barras com letras diferentes mostram diferença estatística significativa $(\mathrm{p}<0,05)$.

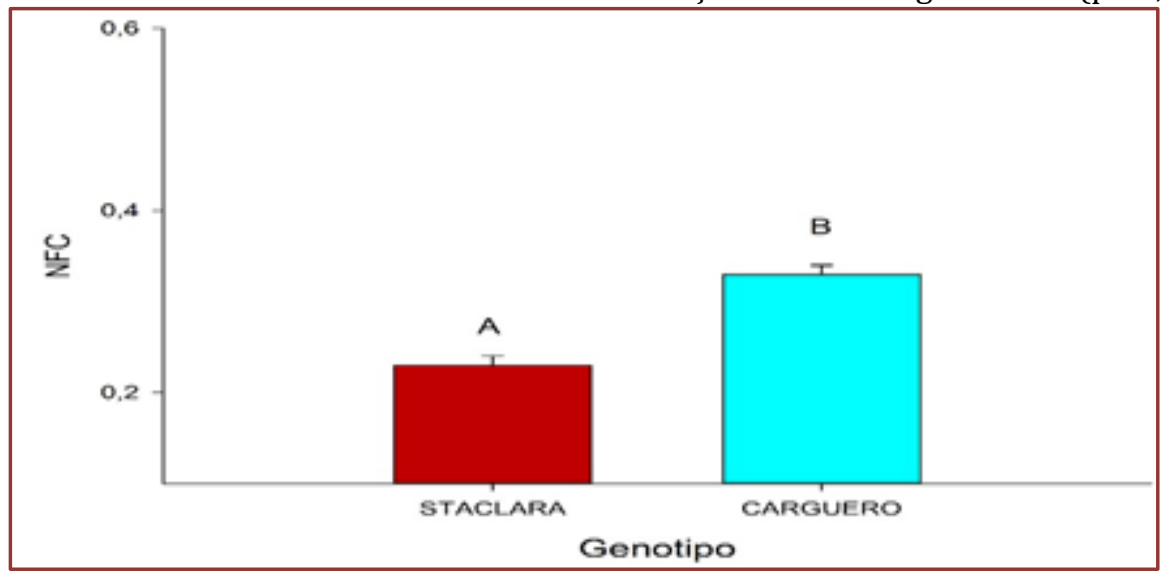


Vallejo-Cabrera (1999) relatou que o genótipo Santa Clara tem resistência à raça 1 de Fusarium oxysporum f. sp. lycopersici, no entanto, Horinouchi et al., (2011) afirmam que o surgimento de novas raças do fungo e de novos biótipos nas raças supera sua resistência, levando à busca de novas estratégias.

\section{CONCLUSÕES}

A bactéria GIBI419 Burkholderia tropica apresentou boa resposta quanto aos componentes de desempenho quando inoculada em tomateiro, mostrando controle sobre os efeitos da murcha vascular causada por Fusarium oxysporum f. sp. Lycopersici.

O genótipo carguero teve bom desempenho na presença da doença, confirmando suas características de resistência e apresentando altos valores em todas as variáveis de desempenho.

\section{REFERÊNCIA}

[1] AMINI, Jahanshir; SIDOVICH, Dzhalilov. The effects of fungicides on Fusarium oxysporum f. sp. lycopersici associated with Fusarium wilt of tomato. Journal of plant protection research, 2010.

[2] CEBALLOS AGUIRRE, Nelson; VALLEJO CABRERA, Franco Alirio. Evaluating the fruit production and quality of cherry tomato (Solanum lycopersicum var. cerasiforme). Revista Facultad Nacional de Agronomía Medellín, v. 65, n. 2, p. 6593-6604, 2012.

[3] CARDONA-PIEDRAHITA, Luisa Fernanda; CASTAÑO-ZAPATA, Jairo; AGUIRRE, Nelson Ceballos. Respuesta de quince introducciones de tomate cherry (Solanum lycopersicum L.) al nemátodo Nodulador (Meloidogyne spp. GOELDI) e identificación de las especies. Revista de la Academia Colombiana de Ciencias Exactas, Físicas y Naturales, v. 40, n. 156, p. 450-460, 2016.

[4] CASTAÑO ZAPATA, Jairo. Prácticas de laboratorio de fitopatología. Universidad de Caldas, Manizales (Colombia). Facultad de Ciencias Agropecuarias. Dept. de Fitotecnia Escuela Agrícola Panamericana, El Zamorano (Honduras). Dept. de Protección Vegetal, 1998.

[5] DE LA CRUZ-LÁZARO, E. et al. Producción de tomate en invernadero con composta y vermicomposta como sustrato. Universidad y ciencia, v. 25, n. 1, p. 59-67, 2009.

[6] DIHAZI, Abdelhi et al. Use of two bacteria for biological control of bayoud disease caused by Fusarium oxysporum in date palm (Phoenix dactylifera L) seedlings. Plant Physiology and Biochemistry, v. 55, p. 7-15, 2012.

[7] FAOSTAT, F. A. O. Available online: http://www. fao. org/faostat/en/\# data. QC (accessed on January 2018), 2017.

[8] GONZÁLEZ, Ivonne; YAILÉN, Arias; PETEIRA, Belkis. Aspectos generales de la interacción Fusarium oxysporum f. sp. lycopersici-tomate. Revista de Protección Vegetal, v. 27, n. 1, p. 1-7, 2012.

[9] HARMAN, Gary E. et al. Trichoderma species—opportunistic, avirulent plant symbionts. Nature reviews microbiology, v. 2, n. 1, p. 43-56, 2004.

[10] HORINOUCHI, Hayato et al. Biological control of Fusarium wilt of tomato with Fusarium equiseti GF191 in both rock wool and soil systems. BioControl, v. 56, n. 6, p. 915-923, 2011.

[11] JOHANSEN, Anders et al. Effects of digestate from anaerobically digested cattle slurry and plant materials on soil microbial community and emission of CO2 and N2O. Applied Soil Ecology, v. 63, p. 36-44, 2013.

[12] RAMYABHARATHI, S.; MEENA, B.; RAGUCHANDER, T. Induction of defense enzymes and proteins in tomato plants by Bacillus subtilis EPC016 against Fusarium oxysporum f. sp. lycopersici. Madras Agric J, v. 100, p. 126-130, 2013.

[13] RESTREPO, G. Obtención y evaluación de un preparado líquido como promotor del crecimiento de cultivos de tomate (Solanum lycopersicum L.) empleando la bacteria Gluconacetobacter diazotrophicus (tesis doctoral). Manizales, Colombia: Doctorado en Ciencias Agrarias, Facultad de Ciencias Agropecuarias, Universidad de Caldas, 2014.

[14] SALAZAR, Edgar Fabián Restrepo; CABRERA, Franco Alirio Vallejo. Diversidad genética del tomate cultivado tipo "chonto", Lycopersicon esculentum Mill, en las zonas productoras de Colombia. Acta Agronómica, v. 52, n. 1, p. 11-17, 2003.

[15] SULTANA, Nasreen; GHAFFAR, Abdul. Effect of fungicides, microbial antagonists and oil cakes in the control of Fusarium oxysporum, the cause of seed rot and root infection of bottle gourd and cucumber. Pak. J. Bot, v. 45, n. 6, p. 2149-2156, 2013.

[16] VALLEJO CABRERA, Franco Alirio et al. Mejoramiento genético y producción de tomate en Colombia. Universidad Nacional de Colombia, 1999.

[17] VIDAL, Valentín et al. Promoción del crecimiento de plantas de tomate inoculadas con Gluconacetobacter diazotrophicus y Burkholderia tropica. Agrotecnia, n. 25, p. 47, 2017.

[18] XU, Mingshuang et al. Bacterial community compositions of tomato (Lycopersicum esculentum Mill.) seeds and plant growth promoting activity of ACC deaminase producing Bacillus subtilis (HYT-12-1) on tomato seedlings. World Journal of Microbiology and Biotechnology, v. 30, n. 3, p. 835-845, 2014. 


\section{Capítulo 3}

\section{Alterações do pH e acidez trocável em solos naturais e antropizados da cidade de Cajapió-MA}

\section{Jonas Juliermerson Silva Otaviano}

Naama Aguiar Moreira

Rennan da Silva de Sousa Moreira

Ana Paula Brito de Sousa

Jorge Diniz de Oliveira

Resumo: 0 estudo dos parâmetros físico-químicos em solos contribuem para obtenção da melhor avaliação dos impactos no ambiente. A deposição inadequada de efluentes domésticos, lixo, supressão vegetal e descarte de materiais tóxicos são exemplos de atividades que atuam na contaminação de grande parte dos biomas brasileiros. 0 presente trabalho busca avaliar alterações nas condições físico-químicas através das análises de $\mathrm{pH}$ e acidez trocável nos ambientes naturais e antropizados em solos da Baixada Maranhense. Foram coletadas amostras de solo da cidade de Cajapió, tendo como universo amostral três ambientes com bom estado de conservação e três ambientes com visíveis impactos antrópicos. Foram realizadas análise de $\mathrm{pH}$ em $\mathrm{H}_{2} \mathrm{O}$ e $\mathrm{KCl}$, e determinação de acidez trocável. Foi identificado no solo investigado forte acidez tanto em ambiente natural quanto antropizado. Soma-se a isso, que em ambientes naturais, os solos estudados apresentaram capacidade de retenção de íons $\mathrm{H}^{+}$e $\mathrm{Al}^{3+}$.

Palavras-chave: Parâmetros físico-químicos; Baixada Maranhense; Ambiente natural; Ambiente antropizado 


\section{INTRODUÇÃO}

O estudo das propriedades físico-químicas, em áreas naturais e antropizadas de solos da Baixada Maranhense, permite avaliar os impactos ocorridos neste ecossistema, os efeitos provocados por atividades antrópicas e a formulação de estratégias que possam conduzir a minimização de danos ocorridos na flora, fauna e saúde humana. 0 desenvolvimento de técnicas relacionadas a correção de acidez causou importante impacto na agricultura, o que antes era visto como espaço inacessível para cultivos, atualmente, tornou-se propício através da aplicação de fertilizantes e variadas tecnologias (DE RESENDE et al., 2016)

Costa Neto (2005) afirma que os campos naturais da Baixada Maranhense servem como áreas de pastagem para o gado bovino e bubalino durante os meses de julho a dezembro, período em que não diminui a ocorrência de chuvas no estado. Nos meses de janeiro a junho, os campos tornam-se totalmente inundados, favorecendo uma elevada biodiversidade, sobretudo de peixes, principal base alimentar e econômica da região. Cavalcante e Lima (2007) afirmam que os solos estudados na Baixada Maranhense mostraram uma grande suscetibilidade à acidez a partir do cálculo da carga crítica parcial (CCP), que para o lago de Viana no pico da chuva mostrou um valor considerado alto $(30,5)$ para a Carga Critica Parcial (CPC).

0 pH é uma importante propriedade química do solo, tanto em relação à disponibilidade de nutrientes que auxiliam na agricultura quanto à presença de elementos tóxicos no ambiente. Para Pes e Arenhardt (2015), o pH expressa a concentração de íons de hidrogênio existente em solução, e nesse contexto, como a concentração é muito baixa, o valor em análise sofre uma transformação logarítmica com escala que varia entre 0 e 14, com neutralidade 7, como a maioria dos solos estão na faixa abaixo de 5, dependendo do cultivo ou objetivo de estudo, é importante elevar o pH para 5,5 e 6,5. 0 processo de acidez do solo pode ocorrer naturalmente, pois há variados fenômenos que induzem a formação de reações ácidas no solo, a ação da água da chuva é um exemplo, ao reagir com $\mathrm{CO}_{2}$ na atmosfera, libera hidrogênio, o que possibilita o processo de acidificação. $0 \mathrm{Al}^{+3}$ contribui para a acidez trocável, pois a quantidade de $\mathrm{H}^{+}$ trocável em solos parece ser relativamente menor, quando em pH abaixo de 5,5. Acima de pH 5,5 não existe mais $\mathrm{Al}^{3}+$ trocável. A acidez trocável está relacionada aos íons $\mathrm{H}^{+}$e $\mathrm{Al}^{3+}$ que estão retidos na superfície dos colóides do solo influenciados por forças eletrostáticas (TEIXEIRA et al, 2017).

Tendo em vista a importância de avaliar os parâmetros físico-químicos e compreender os fenômenos recorrentes nesse ecossistema, esse trabalho objetiva avaliar as alterações do pH e acidez trocável em áreas naturais e antropizadas em solos coletados no município de Cajapió, localizado na zona fitogeográfica da Baixada Maranhense.

\section{METODOLOGIA}

As amostras de solos foram coletadas em áreas naturais e antropizadas da Baixada Maranhense. 0 estudo teve como universo amostral 6 áreas de ambientes de campos alagados no município de Cajapió (Figura 1), sendo 3 áreas com visíveis impactos antrópicos e 3 áreas naturais. As áreas apresentam distância de 2 $\mathrm{km}$. 
Figura 1. Localização geográfica do município e pontos amostrais.

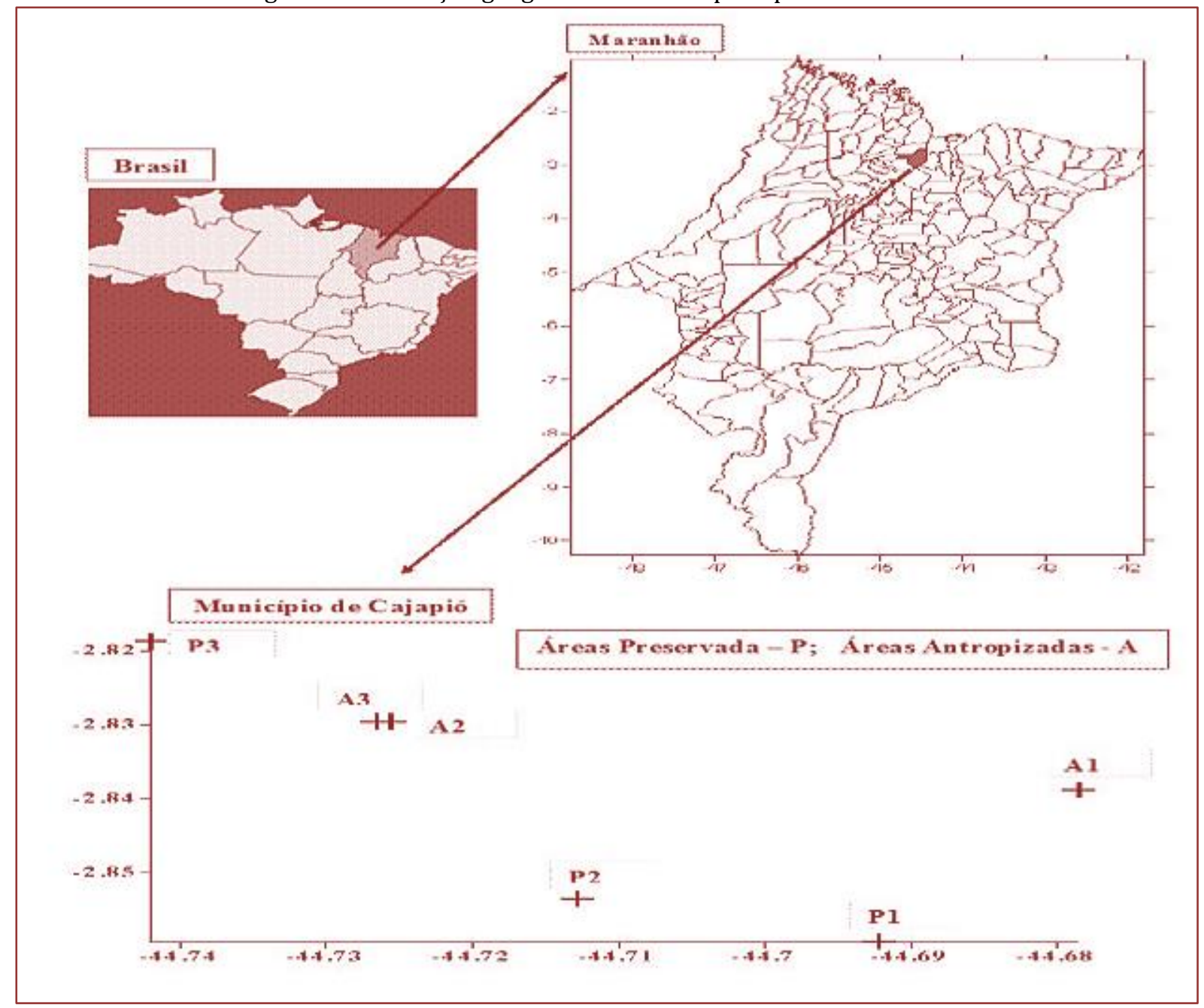

(Fonte: GQA)

A escolha das áreas antropizadas foi baseada na presença de impactos antrópicos decorrentes de desmatamento para plantação de pastagem e pela presença de gados e bubalinos. A coleta e preservação das amostras foram feitas segundo método proposto pela EMBRAPA (2011).

\section{DETERMINAÇÃO DE $\mathrm{pH}$ EM $\mathrm{H}_{2} \mathrm{O}$ E KCL}

As amostras dos solos foram secas ao ar, e passadas em peneira de 0,35 $\mathrm{mm}$ homogeneizadas, e em seguida, submetidas à análise de $\mathrm{pH}$ em água e $\mathrm{KCl} 1 \mathrm{~mol} \mathrm{~L}^{-1}$ foram determinados potenciometricamente em suspensão, empregando 10,0 gramas de cada amostra serão acrescentados $25 \mathrm{~mL}$ de água e solo: $\mathrm{KCl} 1$ mol L-1 e solo (relação 1:2,5) e agitando-se por $40 \mathrm{mim}$. Seguido o intervalo de agitação, o material foi conservado em repouso por $1 \mathrm{~h}$. Em seguida foram feitas as medições do $\mathrm{pH}$ nas amostras segundo Raij et al., (2001). As análises foram feitas em triplicata.

\section{DETERMINAÇÃO DE ACIDEZ TROCÁVEL}

Para análise da acidez trocável do solo foi pesado aproximadamente $5 \mathrm{~g}$ das amostras secas e peneiradas a $2 \mathrm{~mm}$ em um erlenmeyer de $125 \mathrm{~mL}$ em seguida, adicionado $25 \mathrm{~mL}$ de água destilada, utilizando uma proveta, com a posterior adição de $25 \mathrm{~mL}$ de solução de cloreto de sódio $1,0 \mathrm{~mol} \mathrm{~L}^{-1}$ ao erlenmeyer, contendo a suspensão sólida, permaneceu sob agitação durante 20 minutos a $200 \mathrm{rpm}$. Em seguida, a suspensão foi filtrada em papel de filtro qualitativo, os filtrados foram recolhidos em outro erlenmeyer de $125 \mathrm{~mL}$. Os sólidos retidos foram lavados com duas porções de $10 \mathrm{~mL}$ de cloreto de sódio $1,0 \mathrm{~mol} \mathrm{~L}^{-1} \mathrm{e}$ feita a adição de cerca de 4 gotas de fenolftaleína ao filtrado. Logo após, o extrato foi titulado com solução 
de hidróxido de sódio $0,01 \mathrm{~mol} \mathrm{~L}^{-1}$, até mudança de coloração do extrato para a cor rosa. A acidez trocável da amostra foi calculada de acordo com o volume gasto na titulação. A expressão de acidez trocável se dá em mol kg-1 (EMBRAPA, 2011). As análises foram feitas em triplicata.

\section{ANÁLISE ESTATÍSTICA}

Todas as análises foram feitas em triplicata. As médias obtidas foram comparadas pelo teste de Tukey a 5\% de probabilidade utilizando software versão 7.7 Beta (2015).

\section{RESULTADOS E DISCUSSÕES}

De acordo com as análises em campo e laboratório, os solos apresentaram forte acidez, cores pálidas com variação entre vermelhas e amarelas. 0 resultado das análises comprovaram que o solo estudado possui aspectos característicos de plintossolos, sendo a metodologia de identificação e classificação baseada em estudos da Embrapa Solos (2006).

Os procedimentos técnicos na análise de $\mathrm{pH}$ e acidez trocável foram baseados na metodologia de Raij et al (2001). Os valores obtidos para o pH (Tabela 1) na área natural indicam um solo de forte acidez no ponto $A_{1}(\mathrm{pH}<5)$, no ponto $A_{2}$ de acidez fraca $\left(\mathrm{pH} \mathrm{6,2} \mathrm{-} \mathrm{6,3)} \mathrm{e} \mathrm{o} \mathrm{ponto} A_{3}\right.$ com característica ácida $(\mathrm{pH} 5,0-5,6)$. $\mathrm{Na}$ área antropizada os pontos $\mathrm{A}_{1}$ e $\mathrm{A}_{2}$ apresentaram acidez forte, ponto $\mathrm{A}_{3}$ classificada como acidez muito forte, segundo classificação proposta por Pauletti (2004). A partir da análise estatística do pH do solo estudado (Tabela 1) observa-se que os solos revelaram uma alta variação de pH entre as áreas naturais e antropizadas (5\% de coeficiente de variação).

Tabela 1. Comparação estatística entre as médias do pH em ambiente natural e antropizado

\begin{tabular}{|c|c|c|c|}
\hline \multicolumn{1}{|c}{ Ambiente $\mathrm{A} 1$} & \multicolumn{1}{c}{$\mathrm{A} 2$} & $\mathrm{~A} 3$ \\
\hline Área natural & $4,20 \mathrm{bC}$ & $6,39 \mathrm{aA}$ & $5,00 \mathrm{aB}$ \\
\hline Área antropizada & $5,60 \mathrm{aA}$ & $5,08 \mathrm{bB}$ & $4,93 \mathrm{bC}$ \\
\hline
\end{tabular}

As médias seguidas pelas mesmas letras minúscula na coluna e letra maiúscula na linha não diferem estatisticamente entre si. Foi aplicado o Teste de Tukey ao nível de $5 \%$ de probabilidade.

Nas análises descritas na tabela 2 relacionadas ao índice de acidez trocável no ambiente natural e antropizado, ocorreram diferenças significativas entre as áreas de ambiente natural, sendo a área 1 o maior valor, mostrando que a mesma apresenta maior capacidade de retenção do $\mathrm{H}^{+}$e $\mathrm{Al}^{3+}$. Já para ambiente de solo antropizado, resultados mostraram que não há diferenças significativas entre as áreas e consequentemente, evidencia menor capacidade de retenção do $\mathrm{H}^{+}$e $\mathrm{Al}^{3+}$. A comparação da acidez trocável em solos de ambiente natural e antropizado indicaram diferenças significativas entre todas as áreas, tendo como indicativo, que os solos provenientes das áreas sem interferência antrópica tiveram maior capacidade de retenção dos íons $\mathrm{H}^{+}$e $\mathrm{Al}^{3+}$. Embora se tenha observado uma moderada variabilidade para a acidez trocável nas áreas $A_{1}$ e $A_{3}$ para a área natural e $A_{1}$ e $A_{2}$ na área antropizada. A análise estatística indicou variações significativas tanto espacialmente no ambiente como entre as áreas em ambiente natural e antropizado.

Tabela 2. Comparação estatística entre as médias da acidez trocável em ambiente natural e antropizado

\begin{tabular}{|c|c|c|c|}
\hline Ambiente & $\mathrm{A} 1$ & $\mathrm{~A} 2$ & $\mathrm{~A} 3$ \\
\hline Área natural & $14,78 \mathrm{aA}$ & $13,97 \mathrm{aC}$ & $14,35 \mathrm{aB}$ \\
\hline Área antropizada & $10,19 \mathrm{bB}$ & $10,23 \mathrm{bA}$ & $8,43 \mathrm{bC}$ \\
\hline
\end{tabular}

As médias seguidas pelas mesmas letras minúsculas na coluna e letra maiúscula na linha não diferem estatisticamente entre si. Foi aplicado o Teste de Tukey ao nível de $5 \%$ de probabilidade.

Com base nos valores supracitados nas tabelas 1 e 2, depreende-se que os solos investigados nas condições de alta interferência antrópica e ambientes naturais da Baixada Maranhense, evidenciam aspectos de solo com baixa fertilidade, acidez forte que pode dificultar o desenvolvimento de cultivos agrícolas, além de indícios de alto grau de intemperismo. Essas limitações são justificadas pelas condições 
do clima característico desse bioma, além de regiões que em determinada época do ano sofrem com alternância de inundações e períodos de estiagem, essas observações também foram verificadas por Freire e colaboradores (2014).

\section{CONCLUSÕES}

Os resultados obtidos mostraram que os valores de $\mathrm{pH}$ e acidez trocável foram influenciados por processos de interferências antrópicas. 0 solo obteve fortes níveis de acidez com pH que variaram entre 4,20 e 6,39 tanto em ambientes naturais e 4,93 e 5,60 em áreas antropizadas. Com relação aos valores de acidez trocável, os solos provenientes de ambientes naturais apresentaram maior capacidade de retenção dos íons $\mathrm{H}^{+}$e $\mathrm{Al}^{3+}$.

Mesmo apresentando condições desfavoráveis ao desenvolvimento de cultivos agrícolas, a Baixada Maranhense mostra grande potencial para diversas atividades que estão além da pecuária, desde que sejam reconhecidas as necessidade de recuperação de ambientes que foram degradados, áreas que podem ter solos que sejam corrigidos com calagem e adubação para que se tornem cultiváveis.

\section{REFERÊNCIAS}

[1] BRANDÃO, S. L.; LIMA, S. do C. pH e condutividade elétrica em solução do solo, em áreas de Pinus e cerrado na chapada, em Uberlândia (MG). Caminhos de Geografia, v. 3, n. 6, p. 46-56, junho 2002.

[2] CAVALCANTE, P. R. S.; LIMA, R. R. Caracterização físico-química e carga crítica parcial (CCP) para o solo de duas fitofisionomias da baixada maranhense: Campos inundáveis e matas secundárias. Anais do VIII Congresso de Ecologia do Brasil, Setembro de 2007, Caxambu - MG.

[3] DE RESENDE, A. V. et al. Solos de fertilidade construída: características, funcionamento e manejo. Embrapa Milho e Sorgo, 2016.

[4] EMPRESA BARSILEIRA DE PESQUISA AGROPECUÁRIA. Manual de análises químicas de solos, plantas e fertilizantes. 2ª ed. rev. ampl. - Brasília: Embrapa informação Tecnológica, 2009. 627p.

[5] EMPRESA BARSILEIRA DE PESQUISA AGROPECUÁRIA. Sistema Brasileiro de Classificação de Solos. 2 ed. Rio de Janeiro: EMBRAPA; 2006. 306.

[6] EMPRESA BRASILEIRA DE PESQUISA AGROPECUÁRIA-EMBRAPA - Centro Nacional de Pesquisa de Solos. Manual de métodos de análise de solo. 2. Ed. Rio de Janeiro, RJ. 2011, 212 p.

[7] FREIRE, A. T. G.; MENDES, J. J.; BRITO, F. S.; SILVA JUNIOR, C. H. L.; NETO, R. N. L. O ambiente geológicopedológico das planícies inundáveis do maranhão e sua fragilidade às ações antrópicas. XIV Safety, Health and Environment World Congress. July 20 - 23, 2014, Cubatão, Brasil. DOI 10.14684/SHEWC.14.2014.113-117

[8] LOPES, M. C. S.; GUILHERME, L. R. G., Acidez do solo e calagem. Boletim técnico, (Boletim Técnico, 1), São Paulo, 3a ed. Ver ANDA, 1991.

[9] NETO, C. C. Biodisponibilidade de metais pesados em solos do Rio Grande do Sul. 110f. Tese (Doutorado) Programa de Pós- Graduação em Ciência do Solo, Faculdade de Agronomia, Universidade Federal do Rio Grande do Sul, Porto Alegre, 2005.

[10] PAULLETI, V. Nutrientes: Teores e Interpretações. 2ª Edição. Fundação ABC para Assistência e Divulgação Técnica Agropecuária. Castro. Paraná. p. 86, 2004.

[11] Pes, L. Z.; Arenhardt, M. H. Solos. Colégio Politécnico, UFSM - Santa Maria, Colégio Politécnico: Rede e-Tec Brasil, 2015. 90 p.: il.; $28 \mathrm{~cm}$ ISBN 978-85-63573-78-0.

[12] RAIJ, B. V.; ANDRADE, J. C.; CANTARELLA, H.; QUAGGIO, J. A. Analise química para avaliação da fertilidade de solos tropicais. Campinas: Instituto Agronômico, 2001. 285 p.

[13] SILVA, S. A. Distribuição e incerteza da acidez de um Latossolo vermelho amarelo húmico sob Cultivo de café. Revista Brasileira de Ciências do Solo, Ed. 33:1053-1060, 2009.

[14] TEIXEIRA, P. C.; DONAGEMMA, G. K.; FONTANA, A.; TEIXEIRA, W. G. Manual de Métodos de Análise de Solo. 3. Ed. Brasília: Embrapa, 2017. 


\title{
Capítulo 4
}

\section{Diagnose visual de deficiências nutricionais em Physalis peruviana L.}

\author{
Filipe Bittencourt Machado de Souza \\ Ana Izabella Freire \\ Ariana Mota Pereira \\ Renata Ranielly Pedroza Cruz \\ Ivan de Paiva Barbosa \\ Viviane Amaral Toledo Coelho
}

Resumo: 0 cultivo de Physalis peruviana L., popularmente conhecido como fisális, apresenta grande potencial econômico e está sendo aos poucos incorporado aos plantios do grupo de pequenas frutas no Brasil. Entretanto, ainda há necessidade de se aprimorar o manejo cultural, principalmente em questões relativas às necessidades nutricionais, bem o estabelecimento de parâmetros de diagnose visual de deficiência nutricional. Objetivou-se com este trabalho descrever os sintomas visuais de deficiências nutricionais, bem como avaliar o efeito da omissão de nutrientes no crescimento e nutrição mineral de fisális. 0 experimento foi conduzido em casa de vegetação do Departamento de Ciências do Solo da Universidade Federal de Lavras, Lavras, Minas Gerais, Brasil. 0 delineamento experimental utilizado foi o inteiramente casualizado com três repetições e oito tratamentos, em solução nutritiva baseada em solução de Hoagland e Arnon com os seguintes tratamentos: omissões individuais de $\mathrm{Ca}, \mathrm{Mg}, \mathrm{B}, \mathrm{Zn}$, Mn, Fe e múltiplas de CaB e MgMn. Avaliou-se a diagnose visual. As deficiências dos nutrientes nas mudas de fisális se traduziram por sintomas típicos, com exceção da omissão do Zn que não manifestou nenhum sintoma de carência. As omissões de Fe e $\mathrm{CaB}$ foram as mais limitantes para o crescimento vegetativo dessa espécie.

Palavras-chave: Pequenos frutos; Solução nutritiva; Fisális. 


\section{INTRODUÇÃO}

As espécies do gênero Physalis spp., pertencentes à família Solanaceae, constituem um grupo de plantas anuais e perenes que são cultivadas para obtenção de frutos e para decoração. Os frutos de algumas espécies de fisális são comestíveis, têm tamanho similar ao tomate-cereja e são revestidos por um cálice concrescido. Physalis peruviana L., popularmente conhecido como fisális, é um cultivo de grande importância devido ao alto valor nutricional, sabor e potenciais benefícios para a saúde humana. Os frutos podem ser consumidos frescos ou utilizados para produção de geléias (EL-TOHAMY et al. 2009).

No Brasil, o fisális é comercializado como fruta exótica, sendo praticamente inexistente a produção em grande escala. Porém, os frutos de fisális tem grande aceitação pelos consumidores, apresentando um consumo equivalente ou até superior às demais culturas do segmento de pequenas frutas. Entretanto, sua popularidade é restrita ao centro-sul do Brasil. Nas demais regiões, a fruta é relativamente desconhecida. Apresenta valores interessantes do ponto de vista econômico, no entanto, os gastos com o cultivo são elevados, como por exemplo, elevada demanda por mão-de-obra, tempo investido, impostos, embalagem e rotulagem, logística e transporte (MUNIZ; MOLINA; MUNIZ, 2015).

No Brasil, os aspectos técnicos para recomendação de adubação no cultivo do fisális são escassos. Recomendações estas, são realizadas com base emresultados de pesquisa de outras regiões ou, através das indicações para o cultivo do tomateiro (IANCKIEVICZL et al. 2013). Desta forma, os aspectos nutricionais desta planta devem ser mais bem estudados, quantificando assim suas exigências e consequentemente seu crescimento, tornando-se viável determinar o momento mais adequado para iniciar o cultivo, a adubação e os tratos culturais, obtendo-se melhores colheitas de frutos.

Uma ferramenta relevante para o manejo adequado das culturas é avaliação do estado nutricional das plantas. Dentre as formas de avaliação do estado nutricional destaca-se a diagnose visual. Essa diagnose consiste em comparar o aspecto da amostra com o aspecto apresentado por um padrão predeterminado (MALAVOLTA; VITTI; OLIVEIRA, 1997).

A diagnose visual baseia-se em sinais característicos apresentados pelas plantas, sinais estes normalmente observados nas folhas, denominados sintomas. Os sintomas podem caracterizar deficiência ou excesso de determinado nutriente, sintomas estes que diferem dependendo da espécie. Desta maneira, a descrição visual utilizando-se fotografias coloridas, é uma ferramenta de diagnose relevante (CARVALHO, 2001).

Este estudo objetivou caracterizar os sintomas de deficiência nutricional e foliar de fisális cultivadas em solução sob omissão de nutrientes.

\section{MATERIAL E MÉTODOS}

0 experimento foi conduzido em casa de vegetação do Departamento de Ciências do Solos da Universidade Federal de Lavras, em Lavras- MG, entre fevereiro e agosto de 2013. Segundo a classificação de Köppen, o clima da região é do tipo Cwb, mesotérmico ou tropical de altitude, com inverno seco e verão chuvoso, conforme descrito por Souza et al. (2013).

As plantas de fisális utilizadas, foram propagadas via sementes e a germinação ocorreu em bandeja de polietileno expandido de 128 células preenchidas com vermiculita, em condições de telado com sombrite de $50 \%$ por um período de 15 dias. Após a germinação e terem atingido tamanho de aproximadamente 10 cm, as mudas foram transferidas para a solução nutritiva completa de Hoagland e Arnon (1950), com 10\% da sua força iônica para aclimatização por 14 dias. Posteriormente, aumentou-se para $100 \%$ durante a condução do experimento, as quais permaneceram com aeração constante até o final do período de condução experimental (45 dias).

Após o período de adaptação, ocorreu a individualização das plantas em vasos de cinco litros, aplicando-se os tratamentos sob a técnica do elemento faltante. 0 delineamento experimental utilizado foi o inteiramente casualizado (DIC), com três repetições, compostas por três vasos com uma planta cada e oito tratamentos: solução de Hoagland e Arnon completa (controle) e com omissões individuais de Cálcio (-Ca), Magnésio (-Mg), Boro (-B), Ferro (-Fe), Manganês (-Mn) e Zinco (-Zn) e, com omissões múltiplas de Cálcio e Boro (-CaB) e Magnésio e Manganês (-MgMn).

As soluções estoque dos nutrientes foram preparadas com água destilada e reagentes puros (P.A.) e as soluções nutritivas foram preparadas com água deionizada, onde foi completado o volume dos vasos, quando necessário, com a mesma água deionizada. No decorrer do experimento, foram realizadas avaliações visuais para diagnosticar a deficiência de nutrientes. 
Os dados obtidos foram submetidos à análise de variância e as médias comparadas pelo teste Scott \& Knott $(\mathrm{p} \leq 0,05)$. As análises estatísticas foram realizadas com o software Sisvar (FERREIRA, 2011).

\section{RESULTADOS E DISCUSSÃO}

As plantas de fisális sob omissão de B apresentaram folhas novas verde-intenso, reduzidas com deformações e engrossamento do limbo foliar e morte da gema apical (Figura 1). Os resultados corroboram com Souza et al. (2015), que observou na omissão de B brotações laterais e morte prematura do meristema apical, além de clorose em folhas novas e seu encarquilhamento, na parte superior da folha, em amoreira-preta (Rubus spp.). Em relação ao $\mathrm{B}$, sua principal função está relacionada às estruturas primárias da parede celular, mais especificamente na síntese de pectina, celulose e lignina (MORAES et al. 2002). Malavolta; Vitti; Oliveira (1997) relataram que a deficiência de boro afeta negativamente a ação e o transporte dos reguladores de crescimento, além de causar distúrbios no desenvolvimento da planta.

A omissão de Ca provocou irregularidades nítidas nas folhas mais novas. Apresentando encurvamento para baixo, com clorose seguida por necrose nas pontas das folhas. As plantas com deficiência de Ca também apresentaram raízes menos desenvolvidas e mais espessas, com poucas raízes laterais e de coloração escura. A carência de cálcio caracteriza-se pelo baixo crescimento de tecidos meristemáticos, observando-se primeiro nas extremidades em crescimento e em folhas jovens. Características de sintomas de deficiência de cálcio podem incluir a necrose de meristemas jovens, como ponta de raízes ou folhas jovens, onde a divisão celular é mais rápida (MACHADO et al., 2014). As regiões da planta de maior expansão celular foram as mais afetadas pela deficiência de cálcio devido à baixa translocação deste nutriente na planta, de maneira que o aparecimento dos sintomas ocorreu em zonas de crescimento (FAQUIN, 2005).

Ao contrário do que ocorre com o Ca e semelhante ao $\mathrm{K}$, o Mg é móvel no floema, por isso, os sintomas manifestam-se primeiro nas folhas mais velhas. Os sintomas observados foram semelhantes aos descritos por Martinez et al. (2009) estudando sintomas de deficiência de macronutrientes em fisális. A função mais conhecida do Mg é compor a molécula de clorofila (VITTI; LIMA; CICARONE, 2006).

Assim, a deficiência de Mg reduz a taxa fotossintética, provocando clorose, seguida do bronzeamento das folhas velhas. Segundo Taiz e Zeiger (2009), esse padrão de clorose ocorre porque a clorofila nos feixes vasculares mantém- se inalterada por períodos mais longos do que a clorofila nas células entre os feixes, e se a deficiência é intensa, as folhas podem tornar-se amareladas ou brancas, seguidas de necrose.

Figura 1 Sintomatologia das deficiências nutricionais em parte aérea e sistema radicular (raízes) de plantas de fisális mantidas em solução nutritivas completas e com omissões de B, Ca, Mg, Fe, Mn, Zn, CaB e MgMn.

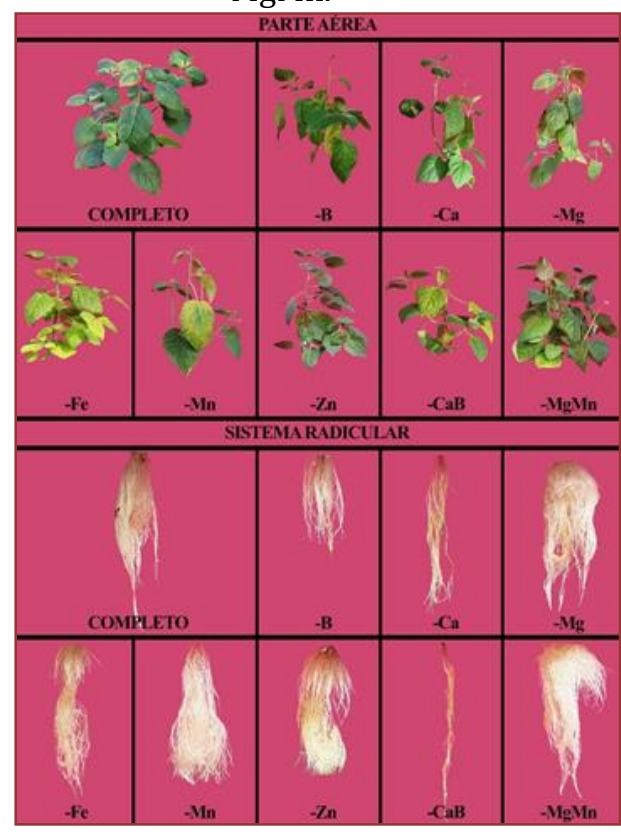


A omissão de Fe nas plantas apresentaram redução do porte vegetal tanto da parte aérea quanto do sistema radicular em relação ao tratamento controle e duração drástica no número de folhas. Em um primeiro momento, verifica-se sobre a superfície das folhas mais novas um tom amarelado, ainda sim a coloração verde manteve- se nas nervuras, estes sintomas são parecidos aos observados por Lange et al. (2005). De acordo com Raij (1991), na planta em desenvolvimento e na adulta, entretanto, não ocorre redistribuição do $\mathrm{Fe}$, causando um amarelecimento da lâmina foliar, enquanto podem manter-se verdes as nervuras por algum tempo, destacando-se como um reticulado muito fino. Em casos extremos, as folhas podem apresentar coloração próxima ao branco.

As folhas mais novas do tratamento com omissão de Mn apresentaram necrose nas pontas das folhas e clorose internerval com aparência de reticulado grosso, ou seja, as nervuras e áreas adjacentes tornaramse verde-escuras, enquanto o restante do limbo foliar apresentava-se amarelado, estes sintomas são semelhantes aos apresentandos por Lange et al. (2005), em mamoneiro cultivar 'Iris'. Um distúrbio na estrutura do cloroplasto, é uma possível causa de sintomas de clorose, como consequência da inibição na síntese de lipídios (ROMHELD, 2001). Hocking e colaboradores (1977), concluem que o sintoma típico de deficiência é a clorose internerval em folhas jovens, pois o manganês é pouco móvel na planta. Rosolem e Bastos (1997) notaram clorose marginal em folhas jovens de algodoeiro, que apresentavam aparência enrugada e limbo com bordas voltadas para baixo.

Na deficiência de MgMn ocorreu clorose internerval com aparência de retículo grosso, clorose seguida de bronzeamento das folhas velhas e o sistema radicular pouco afetado. Os resultados corroboram com Pinho (2007), em plantas de bananeira ornamental em solução nutritiva sob omissão conjunta de MgMn, inicialmente observaram sintomas visuais típicos da carência de $\mathrm{Mg}$ e o crescimento também não foi afetado devido a omissão conjunta desses nutrientes.

A omissão de $\mathrm{CaB}$ as folhas novas apresentaram cor verde-pálidas e recurvadas para baixo, reduzidas com deformações. Além disso, as raízes mostraram-se menos desenvolvidas e mais espessas, com poucas raízes laterais e de coloração escura. De acordo com Petrazzini et al. (2014), a falta simultânea de Ca e B em alface também mostrou crescimento mais lento em relação ao controle, juntamente com várias anormalidades morfológicas nas folhas. Na primeira, as folhas mais jovens mostraram clorose nas fronteiras (típicos de deficiência Ca), que evoluiu para necrose com o progresso da escassez. Deficiência B levou à morte precoce de gemas apicais, espessamento das folhas e as pontas de raízes necróticas levando, portanto, a interrupção do crescimento radicular.

Sob omissões de Zn não manifestaram sintomas característicos de deficiência, o que pode ser explicado pelo fato de que no período de adaptação (em que são fornecidos todos os nutrientes) as plantas podem ter adquirido concentrações adequadas para o seu pleno desenvolvimento, visto que esses micronutrientes são necessários em pequenas quantidades. Outra explicação é a de que as plantas de fisális podem apresentar menor exigência desse nutriente, sendo que, as concentrações mais baixas podem ser suficientes para o desenvolvimento da planta.

Em relação ao número de folhas, os maiores valores foram obtidos para as plantas com deficiência de Zn, sendo superior ao tratamento completo, enquanto que os menores valores foram verificados nas plantas com deficiência de $\mathrm{Fe}, \mathrm{CaB}$ e $\mathrm{Mn}$, sendo inferiores em 54, 36 e 24\%, respectivamente, ao controle. Verificou-se que os nutrientes que mais limitaram o crescimento do fisális foram as omissões de $\mathrm{Fe}$ e $\mathrm{CaB}$, portanto este fato ressalta a importância da prática do uso destes nutrientes durante a adubação, pois, na ausência de um desses nutrientes podem comprometer o desenvolvimento da planta de fisális.

A ausência de cálcio prejudica o crescimento e desenvolvimento das plantas, pois este elemento encontrase no processo fotossintético, na divisão celular, nos movimentos citoplasmáticos e no aumento do volume celular (MALAVOLTA; VITTI; OLIVEIRA, 1997).

\section{CONCLUSÃO}

As deficiências dos nutrientes nas mudas de fisális se traduziram por sintomas típicos, com exceção da omissão do Zn que não manifestou nenhum sintoma de carência.

As omissões de Fe e CaB foram as mais limitantes para o crescimento vegetativo dessa espécie. 


\section{AGRADECIMENTOS}

Os autores agradecem à Fundação de Amparo à Pesquisa do estado de Minas Gerais (FAPEMIG) e ao Conselho Nacional de Desenvolvimento Científico e Tecnológico (CNPq) o apoio financeiro para a conduçãodessa pesquisa.

\section{REFERÊNCIAS}

[1] BRIAT, J. F.; DUBOS, C.; GAYMARD, F. Iron nutrition, biomass production, and plant product quality. Trends in Plant Science, v. 20, n. 1, p. 33-40, 2015.

[2] CARVALHO, G. C. et al. Diagnose da fertilidade do solo e do estado nutricional das plantas. Lavras: UFLA/FAEPE, 2001. 95 p.

[3] DE SOUZA, R. R., et al. Doses de boro no desenvolvimento de copo-de-leite em solução nutritiva. Ciênc. Agrotecnol. v.34, n. 6, p. 1396-1403, 2010.

[4] EL-TOHAMY W. A et al. Response of Cape gooseberry (Physalis peruviana L.) to nitrogen application under sandy soil conditions. Gesunde Pflanzen, v. 61, p. 123-127, 2009.

[5] FAQUIN, V. Nutrição Mineral de Plantas. Lavras: UFLA/ FAEPE, 2005. 183p.

[6] FERREIRA, D.F. SISVAR software: versão 5.1. Lavras: DEX/UFLA, 2011. Software.

[7] HOCKING, P.J. et al. Mn nutrition of Lupins spp. especially in relation to delevoping seeds. Annals of Botany, v. 41, n. 4, p.677-688, 1977.

[8] IANCKIEVICZL, A. et al. Produção e desenvolvimento da cultura de Physalis L. submetida a diferentes níveis de condutividade elétrica da solução nutritiva. Ciência Rural, v. 43, n. 3, p. 438-444, 2013.

[9] JEONG, J.; CONNOLLY, E. L. Iron uptake mechanisms in plants: Functions of the FRO family of ferric reductases. Plant Science, v. 176, p. 709-714, 2009.

[10] LANGE, A. et al. Efeito de deficiência de micronutrientes no estado nutricional da mamoneira cultivar Íris. Pesquisa Agropecuária Brasileira, v. 40, n. 1, p. 61- 67, 2005.

[11] LOCATELLI, M.; MACÊDO, R.S.; VIEIRA, A.H. Avaliação de altura e diâmetro de mudas de Cedro Rosa (Cedrela odorata L.) submetidas a diferentes deficiências nutricionais. Revista Brasileira de Biociências, v. 5, p. 645-647, 2007.

[12] MACHADO, M. P. et al. Influence of calcium content of tissue on hyperhydricity and shoot- tip necrosis of in vitro regenerated shoots of Lavandula angustifolia Mill. Brazilian Archives of Biology and Technology, v. 57, n. 5, p. 636-643, 2014.

[13] MALAVOLTA, E.; VITTI, G.C.; OLIVEIRA, S.A. Avaliação do estado nutricional das plantas: princípios e aplicações. 2ª Ed. Piracicaba: POTAFOS, 1997.319p.

[14] MARTINEZ, E.M. et. al. Síntomas de deficiencia de Macronutrientes y boro em plantas de uchuva (Physalis peruviana L.). Agronomía Colombiana, v. 27, n. 2, p. 169-178, 2009.

[15] MORAES, L. A. C. et al. Relação entre flexibilidade do caule de seringueira e a carência de boro. Pesquisa Agropecuária Brasileira, v. 37, n. 10, p. 1431-1436, 2002.

[16] MORETTI, B. S. et al. Crescimento e nutrição mineral de mudas de cedro australiano (Toona ciliata) sob omissão de nutrientes. Cerne, v.17, n. 4, p. 453-463, 2011.

[17] MUNIZ, J.; MOLINA A. R.; MUNIZ, J. Physalis: Panorama produtivo e econômico no Brasil. Horticultura Brasileira, v. 33, n.2, capa, 2015.

[18] PETRAZZINI, L. L et al. Nutritional deficiency in crisphead lettuce grown in hydroponics. Horticultura Brasileira, v. 32, n. 3, p. 310-313, 2014

[19] PINHO, P.J. de. Deficiências nutricionais em bananeira ornamental (Musa velutina H. Wendl. \& Drude): alterações químicas e morfológicas e caracterização de sintomas visuais. 2007. 147p. Tese (Doutorado em Solos e Nutrição de Plantas) - Universidade Federal de Lavras, Lavras, 2007.

[20] RAIJ, B. V. Fertilidade do solo e adubação. Piracicaba: Ceres Potafos, 1991. 343 p.

[21] ROMHELD, V. Aspectos fisiológicos dos sintomas de deficiência e toxidade de micronutrientes e elementos tóxicos em plantas superiores. In: FERREIRA, M. E. et al. Micronutrientes e elementos tóxicos na agricultura. Jaboticabal: CNPq/FAPESP/ POTAFOS, 2001. p. 71-85.

[22] ROSOLEM, C. A.; BASTOS, G. B. Deficiências minerais no cultivar de algodão IAC- 22. Bragantia, v. 56, n. 2, p. 377-387, 1997. 
[23] Souza, F. B. M. et al. Produção e qualidade dos frutos de cultivares e seleções de pessegueiro na Serra da Mantiqueira. Bragantia, v.72, n.2, 133-139, 2013.

[24] SOUZA, F. B. M. et al. Sintomas visuais de deficiência de macronutrientes, boro e ferro e composição mineral de amoreira-preta. Pesquisa Agropecuária Tropical, v. 45, p. 241-248, 2015.

[25] TAIZ, L.; ZEIGER, E. Fisiologia vegetal. 6aㅡ Ed. Porto Alegre: Artmed, 2017. 719 p.

[26] VITTI, G. C.; LIMA, E.; CICARONE, F. Cálcio, magnésio e enxofre. In: FERNANDES, M. S. (Ed.). Nutrição Mineral de Plantas. Viçosa, MG: Sociedade Brasileira de Ciência do Solo, 2006. p. 299-325. 


\section{Capítulo 5}

Trocas gasosas em capim mombaça (Panicum maximum jaq. cv Mombaça) cultivado sob diferentes níveis de depleção de água no solo

\section{Diego Brandão}

Sergio Nascimento Duarte

Pedro Ramualyson Fernandes Sampaio

Timóteo Herculino da Silva Barros

Osvaldo Nogueira de Sousa Neto

Alan Bernard Oliveira de Sousa

Resumo: A principal forma de alimentação do rebanho bovino brasileiro é através das pastagens. São escassas as informações na literatura sobre as respostas das espécies forrageiras ao manejo da irrigação. Objetivou-se neste trabalho verificar a influência de quatro níveis de depleção de água no solo (15, 30, 45 e 60\%), na taxa fotossintética, na condutância estomática, na transpiração foliar e na eficiência do uso da água do capim mombaça (Panicum maximum Jaq. cv Mombaça), cultivado em vasos, em casa de vegetação, utilizando-se Nitossolo Vermelho (série "Luiz de Queiroz"). 0 delineamento experimental adotado foi o de blocos ao acaso com quatro repetições. As medidas de taxa fotossintética e transpiração foliar foram afetadas pela condição hídrica do solo, apresentando valores máximos respectivos de 21,64 $\mu \mathrm{mol} \mathrm{CO}_{2} \mathrm{~m}^{-2} \mathrm{~s}^{-1} \mathrm{e} 1,246 \mathrm{~mol} \mathrm{H}_{2} \mathrm{O} \mathrm{m}$ ${ }^{2} \mathrm{~S}^{-1}$ para o tratamento com 15\% de depleção de água no solo; decrescendo em 36 e 19\% para o tratamento com $60 \%$ de depleção de água no solo. 0 ajuste fisiológico das plantas em condições de estresse hídrico foi observado com a redução na taxa fotossintética, na condutância estomática, na transpiração foliar e no aumento da eficiência do uso da água para os tratamentos com maiores níveis de estresse.

Palavras Chave: estresse hídrico, irrigação, pastagem. 


\section{INTRODUÇÃO}

As pastagens constituem-se a forma mais prática e econômica para alimentação do rebanho bovino brasileiro. Dentre as espécies forrageiras cultivadas, destacam-se as cultivares de Panicum maximum, por serem altamentes produtivas em matéria seca e de elevado valor nutritivo. No entanto, como toda forrageira tropical, o P. maximum cv. Mombaça está sujeito à estacionalidade de produção. A estacionalidade de produção é a produção desigual de forragem ao longo do ano, comum em regiões onde ocorrem longos períodos de deficiência hídrica no verão (veranicos) ou em invernos secos (RIBEIRO et al., 2009).

A irrigação em pastagens surge como alternativa para reduzir a estacionalidade de produção da espécie forrageira, evitar gastos com alimentos concentrados e mão-de-obra na alimentação dos animais na estação seca. São escassas as informações na literatura sobre as pastagens irrigadas. Quando a irrigação das pastagens não é feita de maneira adequada, leva, geralmente, à aplicação excessiva de água, o que resulta em prejuízos ao ambiente, consumo desnecessário de energia elétrica e de água, lixiviação de nutrientes e maior compactação do solo, repercutindo na diminuição da produção e da vida útil da pastagem (ALENCAR et al., 2009).

A seca é um dos principais fatores de estresse do ambiente, alterando diversos processos fisiológicos das plantas, os quais comprometem o seu crescimento e desenvolvimento e, consequentemente, levam à redução da produtividade. 0 crescimento das plantas está condicionado primordialmente à obtenção de energia proveniente da radiação solar, através da interceptação e utilização no processo de fotossíntese. A fotossíntese líquida do dossel reflete na produção de biomassa, a qual poderá ser influenciada por fatores como: luz, temperatura, umidade, fertilidade do solo, e também pelo manejo adotado (intensidade e frequência de corte ou pastejo), sendo, portanto, importantes condicionadores da arquitetura do dossel.

0 estresse causado pelo deficit hídrico afeta a planta toda, dos pelos radiculares aos estômatos; causa alterações morfológicas como a redução da área foliar, do crescimento das raízes e interfere no fechamento estomático. Respostas fisiológicas ao estresse hídrico variam de acordo com o genótipo das plantas, mas em geral ocorrem devido ao baixo potencial de água no solo, causando baixo potencial nas folhas, incremento na produção de osmoprotetores como açúcares de prolina, redução no conteúdo de água nas folhas, decréscimo na condutância estomática e na taxa fotossintética (GRAÇA et al., 2010).

Os objetivos deste trabalho foram determinar a influência da água disponível no solo na fotossíntese, na condutância estomática, na transpiração foliar e na eficiência no uso da água do capim-mombaça, cultivado em Nitossolo Vermelho (série "Luiz de Queiroz"), em vasos em casa de vegetação.

\section{MATERIAL E MÉTODOS}

A pesquisa foi conduzida em uma casa de vegetação pertencente ao Departamento de Engenharia de Biossistemas da Escola Superior de Agricultura "Luiz de Queiroz", ESALQ/USP, no município de Piracicaba-SP, situado às coordenadas geográficas de $22^{\circ} 42^{\prime}$ de latitude sul e $47^{\circ} 38^{\prime}$ de longitude oeste, com uma altitude de cerca de 540 m, no período de setembro de 2014 a fevereiro de 2015.

Instalou-se um experimento fatorial $4 \times 1 \mathrm{em}$ um delineamento de blocos ao acaso, correspondente a quatro níveis de depleção de água no solo (15, 30, 45 e 60\%) e um solo, Nitossolo Vermelho (série "Luiz de Queiroz") de textura franco-argilosa, com quatro repetições, totalizando-se 16 unidades experimentais constituídas por vasos de $14,3 \mathrm{~kg}$.

O material de solo foi coletado da camada de 0-20 cm do campus da ESALQ/USP, sendo seco ao ar e passado em peneira de malha de $10 \mathrm{~mm}$ para o preenchimento dos vasos e coleta de amostras para análises química e granulométrica. As curvas de retenção de água no solo foram obtidas no Laboratório de Solos do Departamento de Engenharia de Biossistemas da ESALQ/USP, utilizando-se dos métodos da Mesa de Tensão e da Câmara de Richards (1965). Para isso, um vaso de cada classe de solo foi colocado em uma caixa, contendo água ao nível de $2 / 3$ da altura do vaso, para ascensão da água via capilariadade, até a saturação completa. Após a saturação, foram retirados três anéis de Kopeck de cada vaso, os quais foram enviados ao referido laboratório para aplicação das tensões.

o Nitossolo apresentou umidade na capacidade de campo ( $\Theta \mathrm{cc}$ ) de $34 \%$ e umidade no ponto de murcha permantente ( $\Theta \mathrm{pmp}$ ) de $23 \%$, o que resultou em a uma CAD de $11 \%$. A densidade do solo foi obtida retirando-se um anel de Hoghland dos vasos saturados, obtendo-se $1,12 \mathrm{Mg} \mathrm{m}^{-3}$. Com base na análise química os vasos receberam adubo e calcário conforme recomendação de RAIJ et al (1996). 
Foram semeadas $3 \mathrm{~g}$ de sementes por vaso; ocorrida a germinação foram deixadas duas plantas por vaso que foram mantidas com umidade próxima a da capacidade de campo durante 30 dias. Após os 30 dias foi realizado o corte de nivelamento e deu-se início a aplicação dos tratamentos. A irrigação foi feita manualmente com o uso de proveta.

0 monitoramento da umidade era realizado pesando-se quatro vasos (um bloco) diariamente em balança de $30 \mathrm{~kg}$ de capacidade máxima, com precisão de $10 \mathrm{~g}$; a quantidade de água a ser adicionada era aquela suficiente para elevar o solo à capacidade de campo. Considerando-se a profundidade do vaso de 0,30 m, o diâmetro médio do vaso de $0,07 \mathrm{~m}$ e a capacidade de água disponível do solo de $0,11 \mathrm{~cm}^{3} \mathrm{~cm}^{-3}$, calcularamse as lâminas e os volumes que cada tratamento deveria propiciar no momento da irrigação.

As medidas de fotossíntese (A), transpiração foliar (E) e condutância estomática (gs), foram realizadas 30 dias após o corte de nivelamento com o equipamento IRGA (Infra Red Gas Analyser) entre as 8 e 11 horas da manhã, em folhas completamente expandidas de uma mesma planta. A eficiência no uso da água foi obtida pela razão $\mathrm{A} / \mathrm{E}$.

\section{RESULTADOS E DISCUSSÃO}

As medidas obtidas foram submetidas à análise de variância (Tabela 1) e de regressão (Figura 1).

Tabela 1. Resultados da análise de variância.

\begin{tabular}{|c|c|c|c|c|c|}
\multicolumn{2}{|c|}{ FL } & \multicolumn{4}{|c|}{ Quadrado Médio } \\
& & A & E & gs & EUA \\
\hline Depleção & 3 & $201,42^{* *}$ & $0,84^{* *}$ & $0,0003^{* *}$ & $445,06^{* *}$ \\
\hline E. Linear & 1 & $473,15^{* *}$ & $2,50^{* *}$ & $0,0009^{\text {ns }}$ & $572,74^{* *}$ \\
\hline E. Quadrática & 1 & $130,25^{* *}$ & 0,03 & $0,0000^{\text {ns }}$ & $631,01^{* *}$ \\
\hline Erro & 16 & 1,55 & 0,0007 & 0,0000 & 0,63 \\
\hline C.V. & & 2,56 & 3,93 & 0,0000 & 3,98 \\
\hline
\end{tabular}

ns: não significativo $(\mathrm{P}>0,05) ;{ }^{*}$ : significativo $(\mathrm{P}<0,05){ }^{* *}$ : significativo $(\mathrm{P}<0,01)$; C.V.: coeficiente de variação.

FIGURA 1. (a) Taxa fotossintética, (b) condutância estomática, (c) transpiração foliar, (d) eficiência no uso da água.

(a)

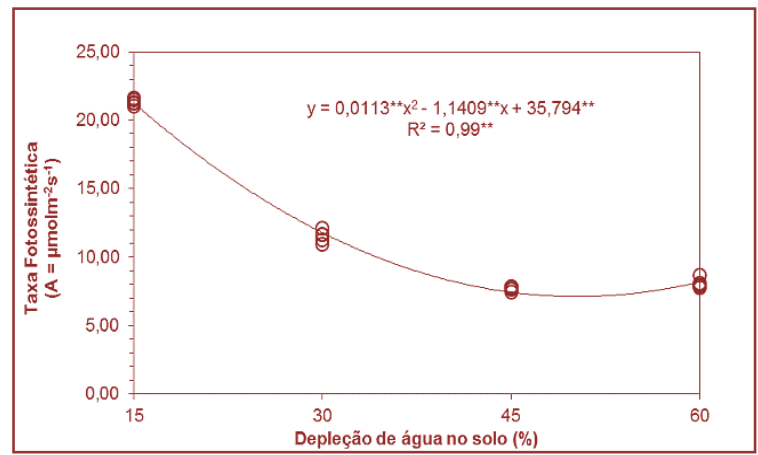

(c)

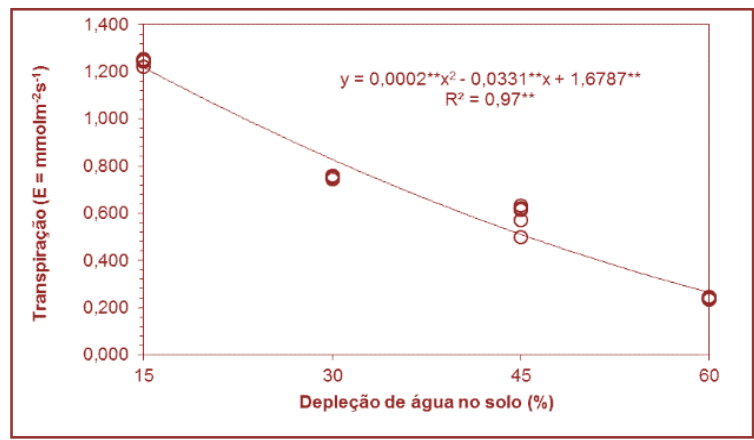

(b)

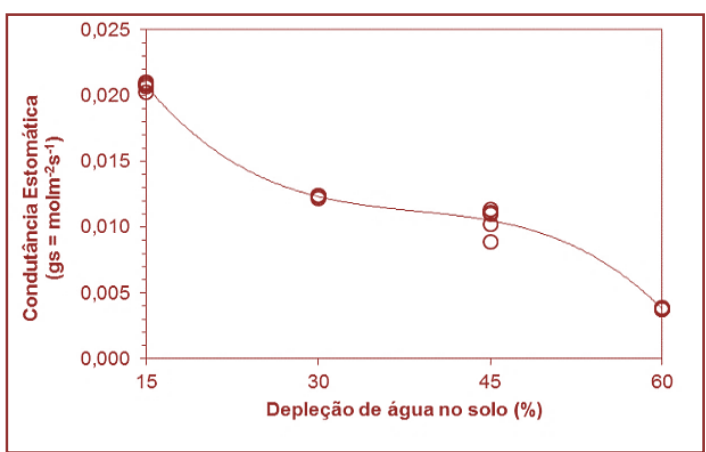

(d)

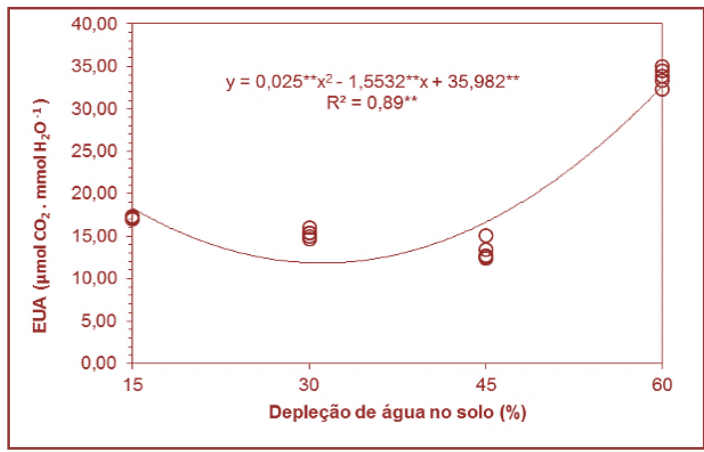


Houve redução na taxa fotossintética, na transpiração foliar e na condutância estomática do capimmombaça conforme houve redução na disponibilidade de água no solo. 0 mesmo foi observado por ARAÚJO et al. (2010), que analisaram três genótipos de capim-elefante em regime irrigado e não irrigado. 0 estresse hídrico causou o fechamento estomático, o que reduziu a perda de água pela planta (CHAVES, 1991; LAWLOR, 1995). Como consequência, a difusão do $\mathrm{CO}_{2}$ no mesófilo foliar foi restringida (FARQUHAR e SHARKEY, 1982). Segundo CORNIC (2000), a diminuição da concentração interna desse gás no sítio de carboxilação da enzima rubisco resulta na limitação da fotossíntese. A eficiência no uso da água variou entre $17,02 \mu \mathrm{mol} \mathrm{CO} 2 \cdot \mathrm{mmol} \mathrm{H}_{2} \mathrm{O}^{-1}$ para as plantas menos estressadas e $34,99 \mu \mathrm{mol} \mathrm{CO}_{2} \cdot \mathrm{mmol} \mathrm{H}_{2} \mathrm{O}^{-1}$ para as plantas mais estressadas, indicando uma aclimatação fisiológica do capim em condição de estresse hídrico. SCALON et al (2011) avaliaram o crescimento inicial das mudas de Guazuma ulmifolia (Mutambo) sob diferentes regimes hídricos: $100 \%, 50 \%, 25 \%$ e 12,5\% da capacidade de campo (CC). A condutância estomática, fotossíntese e transpiração foram menores sob 12,5\% da CC, porém a eficiência no uso da água não variou entre as diferentes condições. GONÇALVES et al (2010) avaliaram o comportamento de quatro variedades de cana-de-açúcar submetidas ao déficit hídrico durante a fase inicial de crescimento, sendo os tratamentos denominados: controle (80 a 100\% da CAD), estresse hídrico moderado (40 a 60\% da CAD) e estresse hídrico severo ( 0 a $20 \%$ da CAD). A deficiência hídrica provocou reduções significativas na condutância estomática (gs), transpiração foliar (E), fotosíntese líquida (A) e na eficiênca de uso da água de produção (EUAp), independente da variedade. Os resultados mostram que sob estresse das primeiras respostas das plantas pode ser o fechamento estomático, de forma a minimizar a perda de água (LARCHER, 2004; TAIZ e ZEIGER, 2004). A tendência de redução nas taxas transpiratórias coincidiu com as reduções observadas na condutância estomática. Esta relação direta entre transpiração e condutância estomática é esperada, tendo em vista a diminuição do fluxo de vapor d'água para a atmosfera e, consequentemente, da transpiração, à medida em que se fecham os estômatos.

\section{CONCLUSÕES}

A fotossíntese foi afetada pela condição de água disponível no solo e decresceu com redução da disponibilidade água, demonstrando que a taxa de assimilação líquida de $\mathrm{CO}_{2}$ foi fortemente afetada pela deficiência hídrica;

A condutância estomática exerce controle sobre a fotossíntese;

Plantas sob níveis de estresse hídrico mais elevado apresentaram maior eficiência no uso da água.

\section{REFERÊNCIAS}

[1] ALENCAR, C. A. B. DE; CUNHA, F. F. DA; MARTINS, C. E; CÓSER, A. C.; ROCHA, W. S. D. DA; ARAÚJO, R. A. S. Irrigação de pastagem: atualidade e recomendações para uso e manejo. R. Bras. Zootec., v.38, p.98-108, 2009.

[2] ARAÚJO, S. A. DO C.; VASQUEZ, H. M.; CAMPOSTRINI, E.; NETTO, A. T.; DEMINICIS, B. B.; LIMA É. da S. Características fotossintéticas de genótipos de capim-elefante anão (Pennisetum purpureum Schum.), em estresse hídrico. Acta Scientiarum. Animal Sciences. Maringá, v. 32, n. 1, p. 1-7, 2010.

[3] CHAVES, M. M. Effects of water deficits on carbon assimilation. Journal of Experimental Botany, v. 42, n. 234, p.1-16, 1991.

[4] CORNIC, G. Drought stress inhibits photosynthesis by decreasing stomatal aperture - not by affecting ATP synthesis. Trends in Plant Science, v. 5, n. 5, p. 187-188, 2000.

[5] GONÇALVES, E. R.; FERREIRA, V. M.; SILVA J. V.; ENDRES, L.; BARBOSA, T. P.; DUARTE, W. de G. Trocas gasosas e fluorescência da clorofila a em variedades de cana-de-açúcar submetidas à deficiência hídrica. R. Bras. Eng. Agríc. Ambiental, v.14, n.4, p.378-386, 2010.

[6] FARQUHAR, G. D.; SHARKEY, T. D. Stomatal conductance and photosynthesis. Annual Review of Plant Physiology, v. 33, p. 317-45, 1982.

[7] GRAÇA, J. P. DA; RODRIGUES, F. A.; FARIAS, J. R. B.; OLIVEIRA, M. C. N. DE; HOFFMANN-CAMPO, C. B.; ZINGARETTI, S. M. Physiological parameters in sugarcane cultivars submitted to water deficit. Brazilian Journal of Plant Physiology, 2010.

[8] LARCHER, W. Ecofisiologia vegetal. São Carlos: RiMa, 2004. 531p

[9] LAWLOR, D. W. Photosynthesis, productivity and environment. Journal of Experimental Botany, v. 46, n. 10, p. 1449-1461, 1995. 
[10] RIBEIRO, E. G.; CARloS FONTES, A. DE A.; PALIERAQUI, J. G. B.; CÓSER, A. C.; MARTINS, C. E.; SILVA, R. C. DA. Influência da irrigação, nas épocas seca e chuvosa, na produção e composição química dos capins napier e mombaça em sistema de lotação intermitente. R. Bras. Zootec., v.38, n.8, p.1432-1442, 2009.

[11] RICHARDS, L. A. Physical conditions of water in soil. In: Black, C. A. (ed.) Methods of soil analysis. Madison: American Society of Agronomy, 1965. p.128-152. Agronomy 9, Part 1.

[12] SCALON, S. DE P. Q.; MUSSURY, R. M.; EUZÉBIO, V. L. DE M.; KODAMA, F. M.; KISSMANN, C. Estresse hídrico no metabolismo e crescimento inicial de mudas de Mutambo (Guazuma ulmifolia Lam.). Ciência Florestal, Santa Maria, v. 21, n. 4, p. 655-662, out.-dez., 2011

[13] TAIZ, L.; ZEIGER, E. Fisiologia vegetal. 3 ed. Porto Alegre: ART-MED, 2004. 719p. 


\title{
Capítulo 6
}

\section{Avaliação in vitro de extrato de própolis no controle de biofilmes microbianos}

\author{
Antonio André Cavalcante Nunes \\ Johnathan Erick Fernandes Gameleira \\ Marcelino Gevilbergue Viana \\ Michelle de Oliveira Guimarães Brasil
}

Resumo: 0 emprego de substâncias naturais no controle de microrganismos nocivos à saúde, como a própolis, mistura resinosa vegetal coletada pelas abelhas, apresenta-se notoriamente viável. 0 trabalho propositou avaliar, in vitro, o efeito do extrato metanólico de própolis sobre biofilmes bacterianos. As amostras de própolis bruta foram extraídas pelo método da tela plástica. 0 extrato foi obtido por meio do aparelho de Soxhlet, sendo calculado seu rendimento. As cepas ATCC utilizadas foram: Staphylococcus aureus, Pseudomonas aeruginosa e Bacillus cereus. Os biofilmes foram obtidos utilizando dentes humanos submergidos em meio de cultura líquido juntos da cepa bacteriana contidos em Erlenmeyers com agitação constante em shaker a 80 rpm/mim por 13 dias. Os antibiogramas foram confeccionados usando quatro tratamentos de extrato. Como controle foi empregado DMSO. Os resultados de taxa de inibição do crescimento microbiano foram obtidos através da análise espectrofotométrica da densidade óptica e dá técnica pour plate. Os resultados mostraram que $P$. aeruginosa foi mais sensível ao extrato metanólico e que a região de coleta e o tempo de armazenamento da própolis bruta podem estar ligados ao seu potencial antimicrobiano.

Palavras-Chave: Extrato de Própolis, Biofilme, Análise, Cepa Bacteriana. 


\section{INTRODUÇÃO}

O termo "biofilme" é predominantemente empregado para descrever uma forma de vida microbiana estruturada, funcional e séssil, caracterizada pela adesão de microrganismos a suportes sólidos (HENRIQUES et al., 2013), com formação dependente da procedência de um fluxo de sais e nutrientes suficientes (RIBEIRO, 2015; LARSEN \& FIEHN, 2017). Os biofilmes, também denominados de "filmes microbianos", podem se desenvolver através da aderência em superfícies abióticas, como plásticos e metais, ou, até mesmo, em superfícies bióticas, como dentes, células, tecidos animais ou vegetais (WRIGHT et al., 2015; TRENTIN et al., 2013).

Essas complexas comunidades apresentam uma típica composição que engloba, basicamente, em grande parcela, água, microrganismos e substâncias poliméricas extracelulares (EPS, "Extracellular Polymeric Substances") produzidas pelos microrganismos que o compõem (HALAN et al., 2012), bem como resíduos do ambiente colonizado, constituindo assim, uma rede com textura gelatinosa que envolve, imobiliza e protege as células da resposta imune, e apresenta um nível elevado de resistência a agentes antimicrobianos (DUTRA, 2016). Dentre os mais variados tipos de microrganismos os mais presentes em biofilmes são as bactérias (ROLIM, 2014).

Algumas espécies bacterianas podem se desenvolver em superfície biótica, como na boca por exemplo, e promover infecções oportunistas e até mesmo sistêmicas, que atualmente são consideradas um problema de saúde pública. Dentre as principais podemos destacar: Staphylococcus aureus, bactéria Gram positiva que possui aptidão de produzir toxinas, estando prevalentemente envolvida em diferentes surtos de intoxicação alimentar (ANDRE, 2015); Bacillus cereus, bactéria Gram positiva, comumente classificada como fator etiológico determinante de duas doenças de origem alimentar, a Síndrome diarreica e Síndrome emética (GRIFFITHS \& SCHRAFT, 2017); e Pseudomonas aeruginosa, bacilo Gram negativa que exibe alta resistência a antibióticos, tido como o principal causador de numerosas infecções hospitalares, especificamente, infecções crônicas pulmonares em pacientes com Fibrose Cística (FC) (WINSTANLEY et al., 2016).

Diferentes produtos são utilizados na prevenção e tratamento da cárie e de outras patologias da boca, oportunistas ou não (MORATA et al., 2015). Todavia, o incremento de novas substâncias como opções é sempre almejado e requerido, principalmente em decorrência da resistência microbiana. À vista disso, o uso de substâncias naturais apresenta-se como método viável, alternativo e ecologicamente correto diante dos baixos impactos ambientais gerados. Dentre esses produtos derivados da natureza, nas últimas décadas, a própolis vem ganhado grande destaque devido a suas inúmeras propriedades biológicas e farmacológicas. (PEREIRA et al., 2015).

A própolis pode ser definida como um complexo agregado de substâncias de origem botânica que possui consistência resinosa, coletada por abelhas Apis mellifera a partir de botões florais, brotos, exsudados de plantas, etc. Para a obtenção do produto final, as abelhas ainda adicionam secreções salivares (contendo enzimas), pólen e cera (MACHADO DE-MELO et al., 2014). Na colmeia, a própolis é usada para tornar o ambiente asséptico e livre de microrganismos patogênicos, além de servir para vedar possíveis frestas e aberturas, contribuindo para o controle da temperatura interna, e para a defesa de inimigos naturais (DE SOUZA et al., 2014; DA SILVA et al., 2015).

Suas propriedades farmacológicas e biológicas estão atribuídas à sua rica composição química, que é variável e dependente da variedade genética da abelha que a produziu e da biodiversidade da região visitada pelas abelhas (DOS SANTOS et al., 2017). Os compostos fenólicos são um complexo agregado de estruturas químicas que compõem a própolis, sendo os flavonoides consolidados como os compostos primordiais, e encontram-se, ainda, alguns ácidos fenólicos e seus ésteres, aldeídos fenólicos, álcoois e cetonas (KAMEYAMA et al., 2015).

Dentre os vários efeitos atrativos da própolis, pode-se destacar sua atividade antibacteriana, antioxidante, antiviral, antifúngica, cicatrizante, antimicrobiana (JUG et al., 2014; NUNES et al., 2018). Vale ressaltar, em meio ao contexto da pandemia do vírus SARS-CoV-2, a importância de estudos com o uso de biocidas naturais que possuem alto potencial terapêutico como tratamento alternativo para doenças infecciosas de origem patogênica, como é o caso da própolis, que devido a sua composição, pode ser indicada para uso profilático em grupos de risco para a covid-19 (BACHEVSKI et al., 2020; BERRETTA et al., 2020; DA SILVA ANTONIO et al., 2020).

Nesse contexto, levando em consideração o alto potencial terapêutico da própolis, o objetivo geral desse trabalho foi avaliar, in vitro, o efeito do extrato metanólico de própolis sobre biofilmes bacterianos formados em superfície dentária. 


\section{MATERIAL E MÉTODOS}

\subsection{LOCALIZAÇÃO E CARACTERIZAÇÃO DA ÁREA DE PESQUISA}

As amostras de própolis bruta foram obtidas no apiário didático pertencente ao Campus do IFRN (Figura 1) localizado no município de Pau dos Ferros (606’ 33" S; 38 12' 16" W. Altitude de 193 m).

Figura 1. Vista aérea da localização do Apiário didático do IFRN - Campus Pau dos Ferros

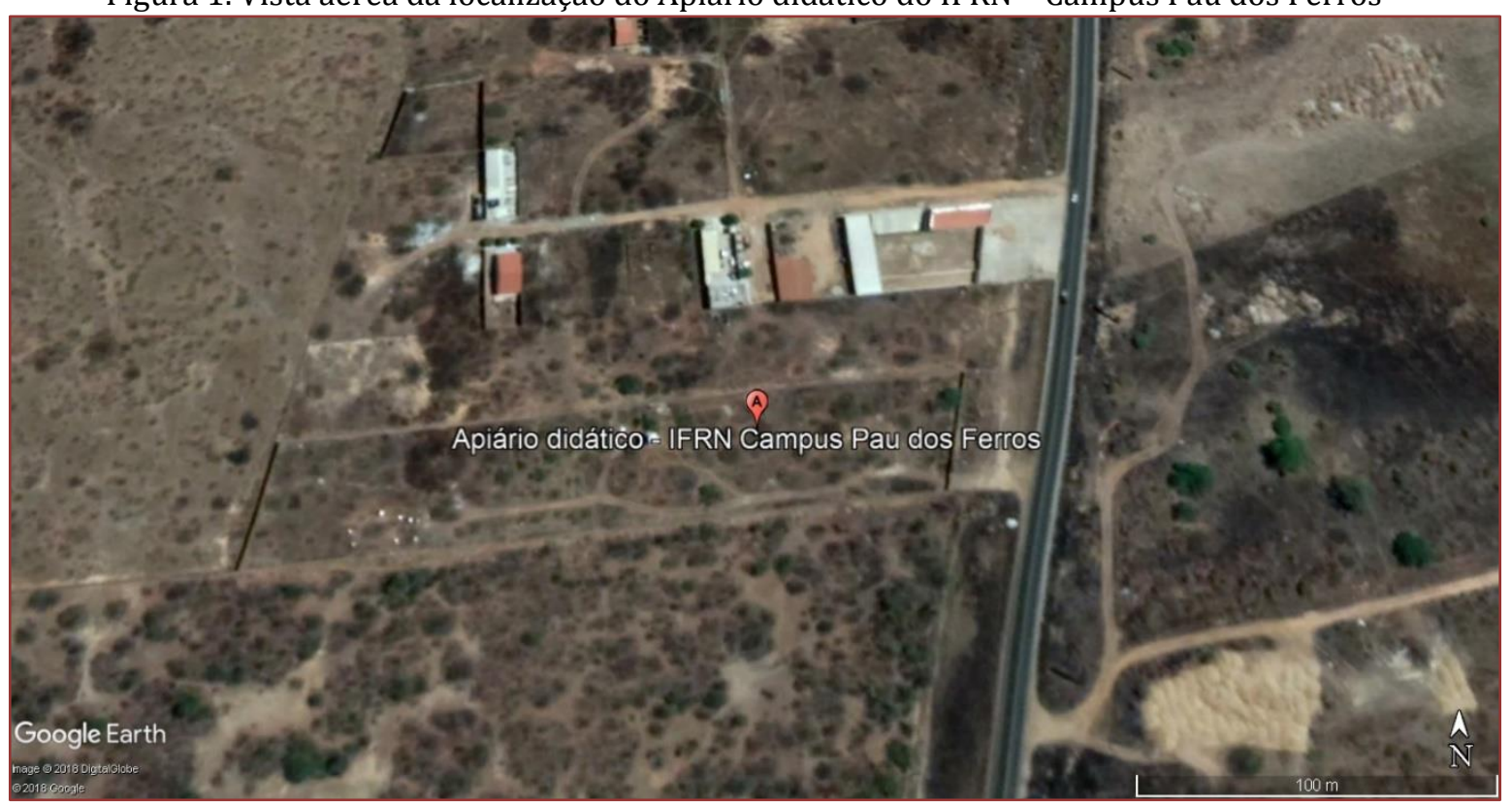

Fonte: Google Earth.

O município de Pau dos Ferros está situado na mesorregião do Alto Oeste Potiguar, interior do estado do Rio Grande do Norte, encontrando-se dentro do clima Semiárido (Bsh), segundo a classificação de Koppen. Apresenta a vegetação da caatinga hiperxerófila, caracterizada pela abundância de cactáceas e plantas de porte mais baixo. Possui uma umidade relativa média anual de 66\%, com uma temperatura média anual de $28^{\circ} \mathrm{C}$. Sua pluviosidade média anual histórica é de $721,3 \mathrm{~mm}$, com chuvas distribuídas entre os meses de fevereiro e junho (IDEMA, 2008; EMPARN, 2011).

\subsection{OBTENÇÃO DA PRÓPOLIS BRUTA}

Para a obtenção da própolis bruta, foram utilizadas quatro colônias de Apis mellifera, alojadas em colmeias padrão Langstroth, todas padronizadas quanto a homogeneidade da prole.

Para a produção das amostras de própolis bruta foi utilizado o métode de produção de inserção de telas plásticas entre a tampa e o ninho da colmeia, na qual permaneceram por um período de um mês, quando foram coletadas. A coleta foi realizada em novembro de 2016, com as amostras permanecendo armazenadas durante onze meses, até a fabricação do extrato.

Logo após a coleta, as amostras foram levadas ao laboratório de Processamento de Pólen e Própolis do IFRN - Campus Pau dos ferros, onde foram embrulhadas em papel filme atóxico e resistente e em papel alumínio, devidamente identificadas quanto a data e o tipo de coleta e submetidas em freezer, em temperatura de $0,5^{\circ} \mathrm{C}$. 0 método de produção utilizado bem como as técnicas de acondicionamento segue a revisão de Breyer et al. (2016).

\subsection{OBTENÇÃO DE EXTRATO POR MEIO DO APARELHO SOXHLET}

O extrato foi preparado no laboratório do IFRN - Campus Apodi (5³7'35.2" S; 3748'28.6" W). Confeccionou-se apenas um único tipo de extrato de própolis, caracterizado de acordo com o tempo de armazenagem e o tipo de coleta, sendo denominado de E1 - Extrato de própolis armazenada pelo método da tela plástica. 
Inicialmente pesaram-se $10 \mathrm{~g}$ de própolis bruta, que em seguida foram arranjados em cartucho preparado com papel filtro. Esse cartucho foi posto no extrator, e este, por sua vez, encaixado em um balão de fundo chato contendo $300 \mathrm{~mL}$ de álcool metílico, a uma temperatura de aquecimento de $75^{\circ} \mathrm{C}$. Esse sistema foi mantido em refluxo por aproximadamente $8 \mathrm{~h}$. Após o resfriamento, o extrato foi vertido em uma proveta de $300 \mathrm{~mL}$. 0 volume final do extrato obtido foi medido e submetido em recipiente vedado e livre de incidência direta de luz. A técnica de obtenção de extrato é semelhante a utilizada por Silva et al. (2013).

\subsection{ANTIBIOGRAMAS}

Os antibiogramas foram preparados utilizando-se meio de cultura sólido TSA para todas as cepas bacterianas avaliadas e serviram como uma verificação da atividade antimicrobiana do extrato. Utilizou-se o método de difusão em ágar, com a técnica de perfuração, consistindo na remoção do meio para a formação de poços onde foi aplicado o extrato a ser analisada. Nos poços, aplicou-se o extrato metanólico de própolis $(0,100,150$ e $200 \mu \mathrm{g} / \mathrm{mL}$, denominados respectivamente "C", "T1", "T2" e "T3"). No poço "C" empregou-se $200 \mu \mathrm{g} / \mathrm{mL}$ de Dimetilsulfóxido (DMSO) como controle, uma vez que a mesma foi usada na diluição do extrato. A atividade antimicrobiana foi avaliada pela obtenção da média do diâmetro do halo de inibição, calculado com o auxílio de uma régua.

Esse ensaio teve como objetivo obter-se a concentração mínima inibitória (CMI) para posteriormente se avaliar sobre os biofilmes. Na ocasião, também se verificou a contaminação do extrato, colocando-o em uma placa com ágar nutriente e posto em estufa bacteriológica ajustada a $35^{\circ} \mathrm{C}$ por $24 \mathrm{~h}$. 0 método de confecção dos antibiogramas é semelhante ao realizado por Ostrosky et al. (2008).

\subsection{OBTENÇÃO DOS BIOFILMES MICROBIANOS}

Para a obtenção dos biofilmes microbianos foram ajustados os inóculos bacterianos a $10^{9}$ células $/ \mathrm{mL}$ na escala McFarand e depositados em Erlenmyers contendo meio de cultura TS líquido. Foram submergidos dentes humanos estéreis no meio de cultura TS contendo o inóculo para a formação dos biofilmes. Os dentes foram doados por consultórios odontológicos da própria região. Em seguida, os Erlenmeyers foram submetidos em agitação em shaker a $80 \mathrm{rpm} / \mathrm{min}$, com temperatura variando entre 35 e $37^{\circ} \mathrm{C}$, sendo mantidos por 13 dias para a formação plena dos biofilmes. Foram utilizadas três cepas bacterianas ATCC de Staphylococcus aureus (ATCC6538), Pseudomonas areuginosa (ATCC27853) e Bacillus cereus (ATCC1140). As cepas foram fornecidas pelo Departamento de Farmácia da Universidade Federal do Rio Grande do Norte - UFRN, sendo as duas primeiras isoladas de pacientes internados, e a última, isolada do solo. A técnica de obtenção de biofilmes utilizada aqui é semelhante a empregada por Viana (2017).

\subsection{AVALIAÇÃO DA ATIVIDADE ANTIMICROBIANA DO EXTRATO METANÓLICO SOBRE BIOFILMES}

Os Erlenmyers contendo os dentes com biofilmes em plena formação foram retirados do shaker, separados e identificados quanto aos diferentes tratamentos de extratos, que em seguida foram aplicados $(0,100$, 150 e $200 \mu \mathrm{g} / \mathrm{mL}$ ). Posterior a colocação do extrato, os biofilmes foram novamente levados ao shaker para serem avaliados por um período de uma hora de contato. Após o período de contato, os dentes foram retirados dos recipientes e decapados para a retirada do biofilme aderido à sua parede, e depois foram mantidos em placas de Petri.

Do biofilme contido nas placas, pipetaram-se $50 \mu \mathrm{g} / \mathrm{mL}$ dos biofilmes de cada tratamento e os estriaram em meio ágar nutriente. As placas foram incubadas à $35^{\circ} \mathrm{C}$ por $24 \mathrm{~h}$, e logo após foi realizada a contagem de unidades formadoras de colônias (UFC). Do restante do biofilme, foram pipetados outros $50 \mu \mathrm{g} / \mathrm{mL}$ e colocados em uma cubeta, junto de água destilada para preencher o volume. Esse material foi submetido em um espectrofotômetro ajustado com um comprimento de onda de $600 \mathrm{~nm}$, para realizar a quantificação bacteriana, estabelecendo a relação de absorbância de $\mathrm{OD}_{600}$. Os métodos de avaliação empregados são semelhantes aos utilizados por Viana (2017) e Domingues et al. (2007).

\subsection{ANÁLISE E TABULAÇÃO DE DADOS}

As taxas de inibição foram obtidas segundo o método proposto por Gudiña et al. (2010), através da fórmula: 
(\%)Taxa de inibição $=\left[1-\left(\frac{A_{c}}{A_{0}}\right)\right] \times 100$

Em que: $A_{c}$ - Absorbância do meio com a concentração c de extrato

$\mathrm{A}_{0}$ - Absorbância do meio sem extrato

As estatísticas e os gráficos foram construídos com auxílio do software Origin, desenvolvido pela OriginLab. Os dados foram analisados estatisticamente pelos métodos ANOVA e teste de Tukey a 5\% $(\mathrm{p}<0,05)$.

\section{RESULTADOS E DISCUSSÃO}

Os extratos foram produzidos segundo o método descrito no item 2.3, tendo o extrato analisado um rendimento final de $300 \mathrm{~mL}$ para cada $10 \mathrm{~g}$ de própolis bruta.

Os resultados do antibiograma constam a baixo na Tabela 1 :

Tabela 1. Atividade antimicrobiana do extrato metanólico E1 de própolis expressa pela média do halo de inibição (\%).

Tabela 1. Atividade antimicrobiana do extrato metanólico E1 de própolis expressa pela média do halo de inibição (\%)

\begin{tabular}{|c|c|c|c|c|}
\hline \multirow[b]{2}{*}{ Microrganismos } & \multicolumn{4}{|c|}{ Média do halo de inibição (\%) } \\
\hline & $\begin{array}{c}\mathrm{T} 1 \\
(100 \mu \mathrm{g} / \mathrm{mL})\end{array}$ & $\begin{array}{c}\text { T2 } \\
(150 \mu \mathrm{g} / \mathrm{mL})\end{array}$ & $\begin{array}{c}\text { T3 } \\
(200 \mu \mathrm{g} / \mathrm{mL})\end{array}$ & $\begin{array}{c}\mathrm{C} \\
\text { (DMSO) }\end{array}$ \\
\hline P. aeruginosa & 50 & 58 & 63 & 70 \\
\hline S. aureus & $\mathrm{n} / \mathrm{o}^{*}$ & $\mathrm{n} / \mathrm{o}$ & $\mathrm{n} / \mathrm{o}$ & 43 \\
\hline B. cereus & $\mathrm{n} / \mathrm{o}$ & $\mathrm{n} / \mathrm{o}$ & $\mathrm{n} / \mathrm{o}$ & 83 \\
\hline
\end{tabular}

Observando os resultados obtidos é possível perceber uma clara sensibilidade da $P$. aeruginosa frente ao extrato analisado. Um resultado semelhante foi observado por Fernandes-Júnnior et al. (2006), que em seu trabalho analisaram in vitro a atividade antimicrobiana de extratos alcóolicos de própolis (EAP) obtidas de três regiões brasileiras diferentes, frente a diferentes linhagens microbianas. A própolis obtida do município de Mossoró - RN (05 11'15" S; $37^{\circ} 20^{\prime} 39^{\prime \prime}$ W) foi a mais eficiente com a P. aeruginosa e não tão eficiente com $S$. aureus, corroborando com os resultados aqui obtidos e justificando que as características biológicas da própolis são variáveis com a região de coleta e as condições sazonais da mesma, uma vez que o município de Mossoró - RN está inserido em uma região com flora e condições climáticas semelhantes aos da localidade em que as amostras de própolis bruta do presente trabalho foram produzidas. A sensibilidade da P. aeruginosa também foi observado por Vargas et al. (2004), que em sua análise considerou esta como a bactéria Gram-negativa mais sensível quando em contato com o extrato alcóolico de própolis.

Ainda com esses resultados é possível notar uma certa diferença destes quando comparados aos encontrados na literatura, onde os extratos de própolis apresentaram em análises, quase em sua completude, atividade antimicrobiana frente a cepas de Staphylococcus aureus e Bacillus cereus (MARCUCCI, 1996; SAEKI et al., 2011). A diferença aqui observada remete a uma provável influência do tempo de armazenamento da amostra de própolis bruta utilizada na produção do extrato.

A composição da própolis bem como sua atividade antimicrobiana, está diretamente associada com a flora e as condições sazonais da região em que as abelhas coletam a resina, além do tempo da colheita e armazenamento, e seus contaminantes (MARCUCCI, 1996; MALASPINA\& PALMA, 2000; PARK et al., 2002; DOS SANTOS et al., 2003). Levando esses fatos em consideração, a não inibição do extrato analisado in vitro em contato com cepas bacterianas de $S$. aureus e B. cereus pode ser justificada pelo tempo de coleta 
da própolis, tendo sido realizada justamente numa época de colheita, onde as condições sazonais e de flora poderiam não ser propícias para resultarem em uma própolis mais ativa biologicamente com relação a essas espécies bacterianas, denotando uma necessidade de estudos de análises com os extratos de amostras coletadas em outras épocas do ano.

Os resultados da atividade antibiofilmes obtidos pela análise espectrofotométrica da densidade óptica e pela contagem de pour plate encontram-se na Figura 2 e 3, respectivamente:

Figura 2. Taxa de inibição de (a) P. aeruginosa, (b) S. aureus e (c) B. cereus após contato com diferentes concentrações do extrato metanólico de própolis obtida pela relação $\mathrm{OD}_{600}$, com teste de Tukey aplicado a $5 \%$.

A)

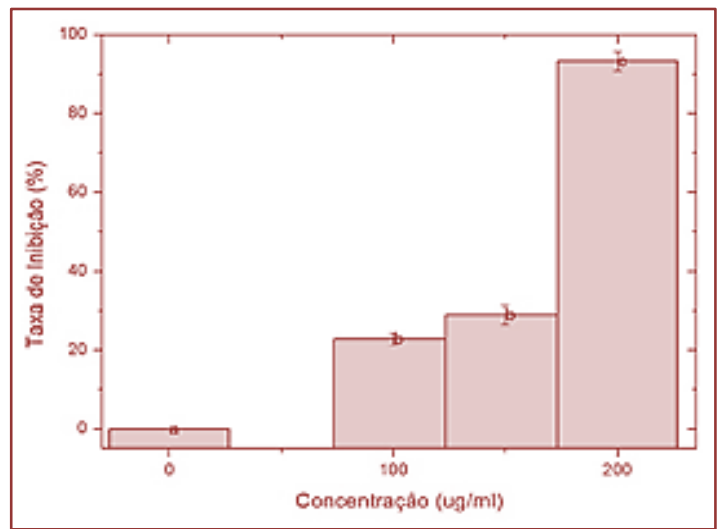

B)

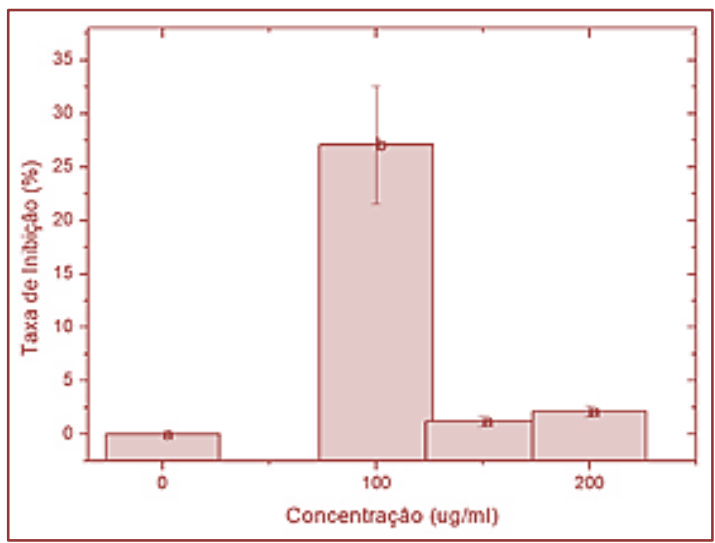

C)

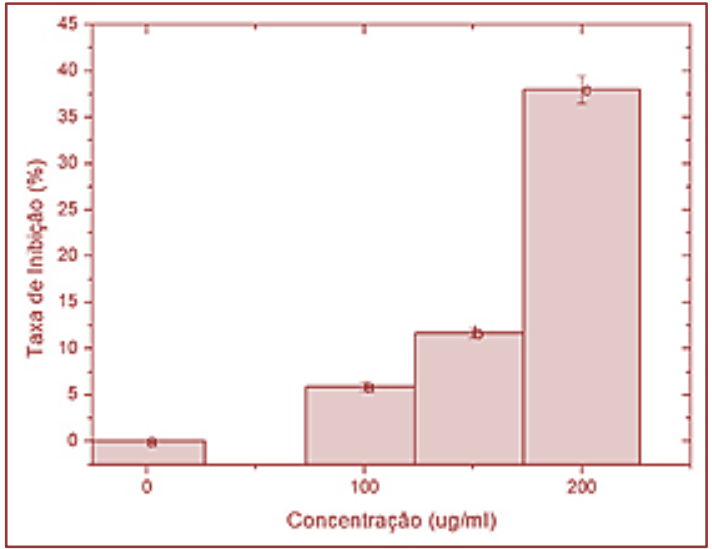


Figura 3: Taxa de Unidades Formadoras de Colônias (UFC) de (a) P. aeruginosa, (b) S. aureus e (c) B. cereus após uma hora de contato com diferentes concentrações do extrato metanólico de própolis, com teste de Tukey aplicado a 5\%.

A)

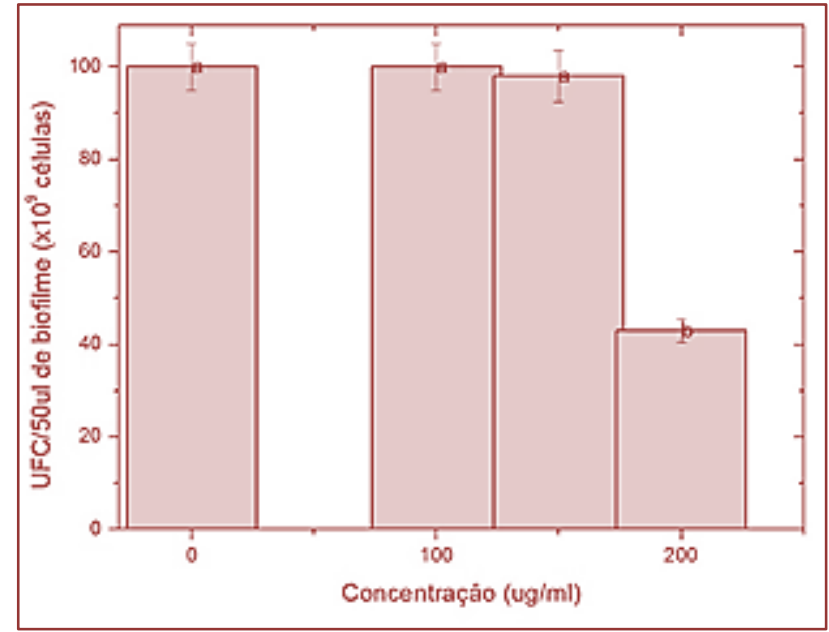

B)

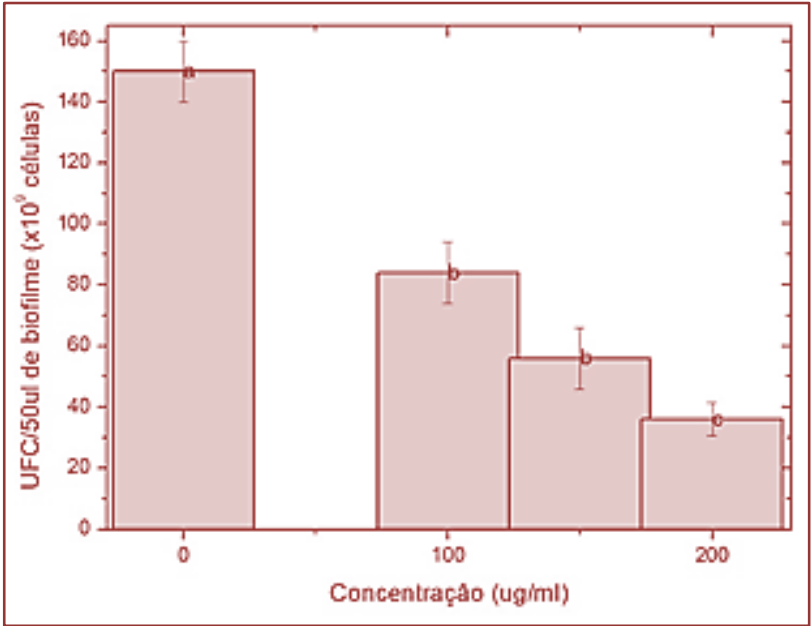

C)

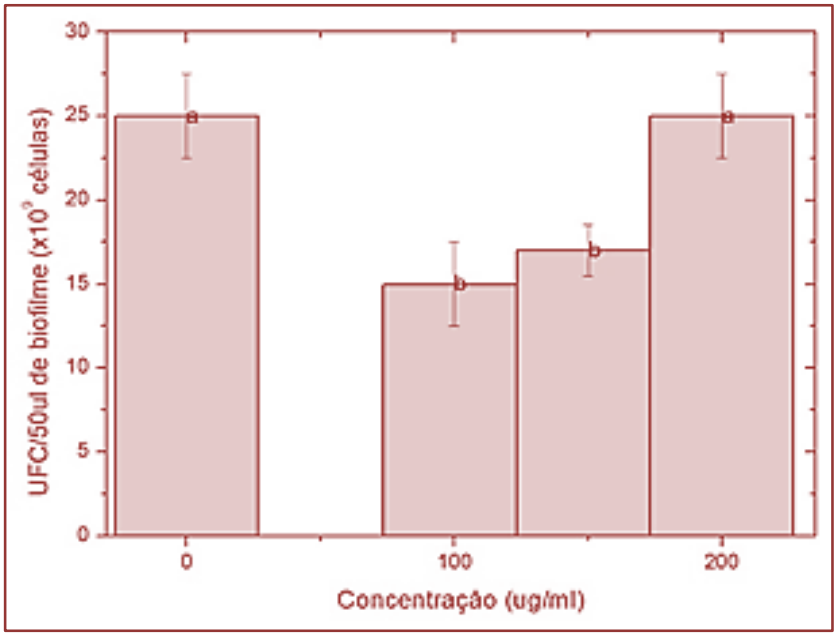

A partir desses dados nota-se uma considerável não corroboração entre os resultados das duas técnicas distintas para as cepas de $S$. aureus e B. cereus, onde para a primeira o tratamento T1 mostrou-se com maior inibição na relação de absorbância, contrariando a metodologia pour plate que mostrou o mesmo tratamento com a maior taxa de crescimento de colônias. Acontece o semelhante para a B. cereus com a T3 
na primeira técnica inibindo mais o crescimento e na segunda técnica, a mesma foi onde o crescimento de colônias foi maior.

Mediante a escassez de estudos sobre os pontos negativos dessas técnicas, infere-se que essa disparidade acontece em decorrência de uma possível ineficiência do método da análise de absorbância pelo espectrofotômetro. Esse procedimento, apesar de essencial para as análises clínicas em geral, pode ter sofrido uma alteração no resultado ao quantificar a absorbância de materiais orgânicos indesejados contidos na cubeta além do extrato, uma vez que o método consiste na verificação da quantidade de luz absorvida por uma solução quando exposta a um feixe de luz monocromático (PORTELA et al., 2017). Nesse caso, a metodologia pour plate torna-se um método de análise mais confiável, onde a $S$. aureus mostrou maior inibição de seu crescimento com a maior concentração testada $(200 \mu \mathrm{g} / \mathrm{mL}$, inibindo cerca de $62 \%$ do crescimento) e a B. cereus, com a menor (100 $\mu \mathrm{g} / \mathrm{mL}$ inibindo cerca de $85 \%$ do crescimento).

A menor resistência da $B$. cereus frente a uma concentração reduzida é observada também por Myers (2008) em sua obra, onde na determinação da Concentração Mínima Inibitória de algumas linhagens bacterianas, a eficácia das substâncias analisadas se mostra maior nas menores concentrações testadas, corroborando assim, com os resultados aqui encontrados e mostrando a necessidade dos testes com concentrações menores do extrato metanólico. Infere-se ainda uma possível má formação de colônias nos biofilmes de $B$. cereus, demarcando essa sensibilidade observada.

Os mesmos testes realizados em biofilmes obtidos a partir da P. aeruginosa ratificaram sua sensibilidade mostrada nas análises in vitro.

\section{CONCLUSÃO}

Diante do exposto concluiu-se que P. aeruginosa foi mais sensível frente ao extrato metanólico de própolis nos ensaios em antibiograma e $B$. cereus em biofilme. A pesquisa mostrou também que o tempo de armazenamento, bem como a sazonalidade, a flora e as condições climáticas da região de coleta são fatores imprescindíveis para as propriedades antimicrobianas da própolis.

Denota-se ainda a necessidade de estudos utilizando extratos de própolis com variados períodos de armazenamento e coletadas em diferentes épocas do ano.

\section{REFERÊNCIAS}

[1] ANDRE, Cleriane et al. Adesão, formação e composição de biofilme por Staphylococcus aureus em poliestireno na presença de nisina. 2015.

[2] BACHEVSKI, Dimitri et al. Back to the basics: Propolis and COVID-19. Dermatologic Therapy, p. e13780$\mathrm{e} 13780,2020$.

[3] BERRETTA, Andresa Aparecida et al. Propolis and its potential against SARS-CoV-2 infection mechanisms and COVID-19 disease. Biomedicine \& Pharmacotherapy, p. 110622, 2020.

[4] BREYER, H.F.E.; BREYER, E.D.H.; CELLA, I. Produção e beneficiamento da propolis. 2016.

[5] DA SILVA ANTONIO, Ananda; WIEDEMANN, Larissa Silveira Moreira; VEIGA-JUNIOR, Valdir Florêncio. Natural products' role against COVID-19. RSC Advances, v. 10, n. 39, p. 23379-23393, 2020.

[6] DA SILVA, Luciana Pellegrini; BOSSO, Adriana Aparecida; CARDOSO, Sibele Camilo. Avaliação da Citotoxicidade da Própolis em Células Meristemáticas de Allium cepa. UNOPAR Científica Ciências Exatas e Tecnológicas, v. 9, n. 1, 2015.

[7] DE SOUZA, Flávia Barbosa; SOUZA, Darclet Teresinha Malerbo. PRODUÇ̃̃o DE PRÓPOLIS DAS ABELHAS AFRICANIZADAS, NO CAMPUS DO CENTRO UNIVERSITÁRIO MOURA LACERDA, NO DECORRER DO ANO DE 20131. PRIMEIROS PASSOS, p. 59, 2014.

[8] DOMINGUES, Vanessa Oliveira et al. Contagem de bactérias heterotróficas na água para consumo humano: comparação entre duas metodologias. Saúde (Santa Maria), v. 33, n. 1, p. 15-19, 2007.

[9] DOS SANTOS, C. R. et al. Otimização do processo de extração de própolis através da verificação da atividade antimicrobiana. Revista Brasileira de Farmacognosia, v. 13, p. 71-74, 2003.

[10] DOS SANTOS, D.; DAVID, Jorge Mauricio; DAVID, Juceni Pereira. Composição química, atividade citotóxica e antioxidante de um tipo de própolis da Bahia. Quim Nova, v. 40, p. 171175, 2017.

[11] DUTRA, Tatiane Viana. Avaliação da formação de biofilmes de Escherichia coli e Staphylococcus aureus em superfície de aço inoxidável. Trabalho de Conclusão de Curso. Universidade Tecnológica Federal do Paraná. 2016. 
[12] EMPARN. Empresa de Pesquisa Agropecuária do Rio Grande do Norte. ANÁLISE PLUVIOMÉTRICA DO RIO GRANDE DO NORTE. PERÍODO: 1963 - 2009. Natal/RN, 2011. Disponível em:

http://adcon.rn.gov.br/ACERVO/EMPARN/DOC/DOC000000000000609.PDF. Acesso em: 04 dez. 2018.

[13] FERNANDES JÚNIOR, Ary et al. Atividade antimicrobiana de própolis de Apis mellifera obtidas em três regiões do Brasil. Ciência Rural, p. 294-297, 2006.

[14] GRIFFITHS, M. W.; SCHRAFT, H. Bacillus cereus food poisoning. In: Foodborne Diseases (Third Edition). p. 395-405. 2017.

[15] GUDIÑA, Eduardo J. et al. Antimicrobial and antiadhesive properties of a biosurfactant isolated from Lactobacillus paracasei ssp. paracasei A20. Letters in applied microbiology, v. 50, n. 4, p. 419-424, 2010.

[16] HALAN, B., BUEHLER, K., SCHMID, A. Biofilms as living catalysts in continuous chemical syntheses. Trends in Biotechnology, vol. 30, p.453-465, 2012.

[17] HENRIQUES, Ana; VASCONCELOS, Carlos; CERCA, Nuno. A importância dos biofilmes nas infeções nosocomiais: 0 estado da arte. Arquivos de Medicina, v. 27, n. 1, p. 27-36, 2013.

[18] IDEMA. Instituto de Desenvolvimento Sustentável e Meio Ambiente do Rio Grande do Norte. Perfil do seu município: Pau dos Ferros. Natal/RN, 2008. Disponível em: http://adcon.rn.gov.br/ACERVO/idema/DOC/DOC000000000013919.PDF. Acesso em: 04 dez. 2018.

[19] JUG, Mario; KONČIĆ, Marijana Zovko; KOSALEC, Ivan. Modulation of antioxidant, chelating and antimicrobial activity of poplar chemo-type propolis by extraction procures. LWT-Food Science and Technology, v. 57, n. 2, p. 530$537,2014$.

[20] KAMEYAMA, Oswaldo et al. Extrato de própolis na sanitização e conservação de cenoura minimamente processada. Ceres, v. 55, n. 3, 2015.

[21] LARSEN, Tove; FIEHN, Nils-Erik. Dental biofilm infections-an update. Apmis, v. 125, n. 4, p. 376-384, 2017.

[22] MACHADO DE-MELO, Adriane Alexandre et al. Capacidade antioxidante da própolis. Pesquisa Agropecuária Tropical, v. 44, n. 3, 2014.

[23] MALASPINA, Osmar; PALMA, Mario Sergio. Propolis brasileira: controle de qualidade e legislação. In: Congreso Internacional de Propóleos, Buenos Aires-Argentina. 2000.

[24] MARCUCCI, Maria Cristina et al. Propriedades biológicas e terapêuticas dos constituintes químicos da própolis. Química Nova, v. 19, n. 5, p. 529-536, 1996.

[25] MORATA, L.; MENSA, J.; SORIANO, A. New antibiotics against gram-positives: present and future indications. Current Opinion in Pharmacology, n. 24, p. 45-51, 2015.

[26] MYERS, F. Biocidal agents: modes of action and correlation with antibiotic resistance. BIOMEDICAL SCIENTIST, v. 52, n. 3, p. 227, 2008.

[27] NUNES, Elaine Oliveira Rocha; MACHADO, Elisângela Lúcia; PAULA, Gislene Baptista Santos de. O USO DA PRÓPOLIS COMO ANTIBIÓTICO NATURAL. 2018.

[28] OSTROSKY, Elissa A. et al. Métodos para avaliação da atividade antimicrobiana e determinação da concentração mínima inibitória (CMI) de plantas medicinais. Revista Brasileira de Farmacognosia, v. 18, n. 2 , p. 301 $307,2008$.

[29] PARK, Yong Kun et al. Própolis produzida no sul do Brasil, Argentina e Uruguai: Evidências fitoquímicas de sua origem vegetal. Ciência rural, 2002.

[30] PEREIRA, Daniel Santiago et al. Histórico e principais usos da própolis apícola. Embrapa Amazônia OrientalArtigo em periódico indexado (ALICE), 2015.

[31] PORTELA, Benedito et al. ESPECTROFOTOMETRIA, ESSENCIAL PARA ANÁLISES CLÍNICAS. Mostra Científica em Biomedicina, v. 1, n. 1, 2017.

[32] RIBEIRO, Maria Cecília Enes et al. Adesão e formação de biofilme por Bacillus cereus em aço inoxidável. 2015.

[33] ROLIM, Marta Ferreira. Contribuição para o estudo da caracterização de biofilmes de diferentes idades. Tese de Doutorado. 2014.

[34] SAEKI, Erika Kushikawa et al. Mastite bovina por Staphylococcus aureus: sensibilidade às drogas antimicrobianas e ao extrato alcoólico de própolis. Acta Veterinaria Brasilica, v. 5, n. 3, p. 284-290, 2011.

[35] SILVA, Ellen C. C. da; MUNIZ, Magno P.; NUNOMURA, Rita de C. S.; NUNOMURA, Sergio M.; ZILSE, Gislene A. C. Constituintes fenólicos e atividade antioxidante da geoprópolis de duas espécies de abelhas sem ferrão amazônicas. Revista Química Nova, v.36, n. 5, p. 628-633. 2013. 
[36] TRENTIN, D. da S.; GIORDANI, R. B.; MACEDO, A. J. Biofilmes bacterianos patogênicos: aspectos gerais, importância clínica e estratégias de combate. Revista Liberato, v. 14, n. 22, p. 113-238, 2013.

[37] VARGAS, Agueda Castagna et al. Atividade antimicrobiana "in vitro" de extrato alcóolico de própolis. Ciência Rural, v. 34, n. 1, p. 159-163, 2004.

[38] VIANA, M. G. Isolamento de microrganismos endofíticos de Lippia gracilis Schauer (Verbenaceae), avaliação do óleo essencial da planta e dos metabólitos dos endofíticos sobre a corrosão microbiologicamente induzida (CMI) em aço carbono AISI 1020. 2017. 216 f. Tese (Doutorado em Biotecnologia) - Universidade Federal do Rio Grande do Norte, Natal-RN, 2017.

[39] WINSTANLEY, Craig; O’BRIEN, Siobhan; BROCKHURST, Michael A. Pseudomonas aeruginosa evolutionary adaptation and diversification in cystic fibrosis chronic lung infections. Trends in microbiology, v. 24, n. 5, p. 327-337, 2016.

[40] WRIGHT, G. Antibiotics: An irresistible newcomer. Nature, v. 517, p. 442-444, 2015. 


\section{Capítulo 7}

Características físico-químicas de frutos de Noni

Rita de Cássia Santos Nunes

Fabricio Vieira Dutra

Mariana Costa Rampazzo

Gabriela Leite Silva

Adriana Dias Cardoso

Alcebíades Rebouças São José

Resumo: Objetivou-se nesse estudo, determinar as características físicas e físicoquímicas de frutos de noni in natura cultivados no Planalto de Vitória da Conquista. 


\section{INTRODUÇÃO}

O noni (Morinda citrifolia L.) é uma espécie e originária do Sudeste da Ásia e da Austrália, onde vem sendo utilizada há muitos séculos, e que tem sido ser cultivada em várias partes do mundo (TOMBOLATO; BARBOSA; HIROCE, 2005). Apesar da grande utilização e demanda internacional pelos produtos oriundos desta espécie, principalmente o suco dos frutos, é bastante recente a tentativa de cultivo do noni no Brasil, que é realizado empiricamente por pessoas que trouxeram sementes do Caribe ou da Polinésia (SOUSA et al., 2010).

Ainda que o noni seja pouco conhecido, seus benefícios nutricionais e fitoterápicos têm sido divulgados 0 fruto é considerado um poderoso antioxidante natural e o seu consumo diário, na forma de suco, auxiliam o sistema imunológico e aumenta a capacidade das células na absorção de nutrientes.(TOMBOLATO; BARBOSA; HIROCE, 2005).

O processamento da polpa de frutos para produção de sucos e outros produtos pode ser maximizada a partir do conhecimento de sua composição físico-química. Em virtude da escassez de informações acerca da qualidade dos frutos cultivados em diferentes regiões do território brasileiro, objetivou-se determinar as características físicas e físico-químicas de frutos de noni in natura cultivados no Planalto de Vitória da Conquista.

\section{2 .FUNDAMENTAÇÃO TEÓRICA}

0 fruto do noni foi introduzido recentemente como matéria-prima de forte apelo comercial devido às características benéficas a ele atribuídas e os benefícios relacionados o seu consumo (SILVA et al., 2012).

É possível encontrar frutos em diferentes estágios de maturação na mesma planta, ao mesmo tempo. A polpa, creme, carnosa e suculenta, apresenta sabor e aroma não muito agradáveis,próximo ao sabor de um queijo maturado. As sementes, mais de 100 por fruto grande, são triangulares a alongadas, marrons e medem entre 3 e 10 mm de comprimento (BELTRÃO; SOUZA; SILVA, 2014).

Os caracteres físicos dos frutos referentes à aparência externa, tamanho, forma e cor da casca e as características físico-químicas relacionadas ao sabor, odor, textura e valor nutritivo constituem atributos de qualidade à comercialização e utilização da polpa na elaboração de produtos industrializados (CHITARRA e CHITARRA, 2005).

0 amadurecimento é a fase mais estudada na pós-colheita de frutos, principalmente por ser nessa fase que as mudanças na composição dos frutos ocorrem com mais intensidade (SILVA, et al., 2013) .

As principais alterações sensoriais que ocorrem em frutas durante o amadurecimento e que são finalizadas durante a senescência estão relacionadas à textura, aparência e sabor. Essas alterações podem ser percebidas por análises físicas, químicas, bioquímicas ou sensoriais (CAVALINI, 2008).

No controle de qualidade de frutos, os parâmetros como acidez titulável, sólidos solúveis e pH são importantes para a padronização do produto e análise de alterações ocorridas durante processamento e armazenamento (DANTAS et al., 2010).

\section{MATERIAL E MÉTODOS}

Os frutos de noni utilizados no experimento foram provenientes de plantas no município de Vitória da Conquista-BA, localizada a 1451'58” de Latitude Sul e 4050'22" de Longitude Oeste, em altitude média de $941 \mathrm{~m}$ e clima conforme classificação de Köppen do tipo Cwa (tropical de altitude). A temperatura média anual da região é de $20,2^{\circ} \mathrm{C}$ e a precipitação anual de 733,9 mm (INMET, 2017).

Os frutos em diferentes estádios de maturação foram colhidos diretamente na copa da planta e classificado de acordo o tamanho e a coloração em estágios semi-maduro e maduro, formando 10 amostras composta, constituída de 20 frutos de noni em cada amostra. Posteriormente, foram conduzidos ao Laboratório de Melhoramento e Produção Vegetal, da Universidade Estadual do Sudoeste da Bahia, UESB, onde foram realizadas as análises. 
Para as avaliações físico-químicas, foi realizado o despolpamento dos frutos em um processador. Em seguida, a polpa foi homogeneizada em gral pistilo e, a partir desta, procederam-se as análises. As características avaliadas foram: a) sólidos solúveis (SS),determinado utilizando-se refratômetro portátil Atto WYT4, de acordo com o método da AOAC (1982); b) acidez titulável (AT), obtida por titulação com solução de NAOH 0,1 N e indicador fenolftaleína, segundo a metodologia do Instituto Adolfo Lutz (1985), calculada em \% de ácido cítrico $100 \mathrm{~g}^{-1}$ de polpa; c) pH determinado pelo método da AOAC (1982), utilizando-se medidor de pH, modelo MB10, Marte.

Os dados obtidos foram tabulados e calculados, obtendo-se as respectivas médias, mediana, variância, desvio padrão e coeficiente de variação utilizando-se planilha eletrônica, do Microsoft Office - Excel 2010.

\section{RESULTADOS E DISCUSSÕES}

As médias aritméticas do comprimento, largura, espessura e massa fresca dos frutos de noni, com seus respectivos erro padrão e coeficiente de variação estão apresentados na Tabela 1.

Pode-se observar nessa tabela grande variação para massa fresca e comprimento dos frutos. Além disso, verifica-se também, com base nos coeficientes de variação, alto padrão de variação fenotípica, superior a $20 \%$ para essas duas características, quando comparados com o trabalho de Silva, et al. (2012). Por outro lado, as características de largura e comprimento do fruto apresentaram pequena variação, com valores semelhantes, de 10,08 e 10,11\%, respectivamente.

Tabela 1. Características morfológicas de frutos de noni cultivados em Vitória da Conquista, BA, 2018

\begin{tabular}{|c|c|c|c|c|}
\hline Características & $\begin{array}{l}\text { Comprimento do } \\
\text { fruto (mm) }\end{array}$ & $\begin{array}{l}\text { Largura do } \\
\text { fruto ( } \mathrm{mm})\end{array}$ & $\begin{array}{l}\text { Espessura do } \\
\text { fruto (mm) }\end{array}$ & Massa do fruto ( $\mathrm{g}$ ) \\
\hline Mínimo & 25,90 & 42,05 & 38,06 & 37,60 \\
\hline Máximo & 97,14 & 60,16 & 57,72 & 175,52 \\
\hline Média & 71,42 & 50,13 & 46,64 & 108,44 \\
\hline Mediana & 80,18 & 49,47 & 47,18 & 113,92 \\
\hline Variância & 472,07 & 25,52 & 22,30 & 2058,23 \\
\hline Desvio Padrão & 21,73 & 5,05 & 4,72 & 45,37 \\
\hline $\mathrm{CV}(\%)$ & 30,43 & 10,08 & 10,11 & 41,84 \\
\hline
\end{tabular}

No presente trabalho, a média de massa fresca encontrada para os frutos foi de 108,44, conforme Tabela 1. Esse valor se aproxima daqueles encontrados por Sátiro et al. (2017), ao avaliarem frutos verdes, com média de 119,8g e maduros, com média de 82,4g, na Paraíba. Entretanto, Silva et al. (2013), trabalhando com frutos no Trairi-CE verificaram variação entre 195,60 g a 258,80 g, com média geral de 221,50 g.

As características químicas (firmeza, pH, sólidos solúveis, acidez titulável e colorimetria) dos frutos de noni são apresentados na Tabela 2 .

A média obtida para firmeza do fruto de noni no presente trabalho foi de 119,63, com coeficiente de variação elevado 32,44. Essa variação é indicativa da diferença de maturidade dos frutos avaliados. Segundo Chitarra e Chitarra, (2005), a manutenção da firmeza está relacionada à integridade dos polímeros da parede celular, que durante a maturação sofrem transformações, levando à perda de estrutura e, em consequência, ao amaciamento da textura do fruto.

O valor médio encontrado para $\mathrm{pH}$ foi de 4,17, muito próximo ao relatado por Canuto et al. (2010),os quais verificaram valores de 4,1.Outros trabalhos (SILVA et al., 2013; BELTRÃO; SOUZA; SILVA, 2014; SÁTIRO et al., 2017) apresentam mais larga variação, entre 4,32 a 5,23, em frutos com diferentes estágios de maturação(verde e maduro). 
Tabela 2. Características químicas de frutos de noni cultivados em Vitória da Conquista, BA, 2018.

\begin{tabular}{|c|c|c|c|c|c|c|c|}
\hline Características & $\begin{array}{c}\text { Firmeza } \\
(\mathrm{N})\end{array}$ & $\mathrm{pH}$ & SS ( ${ }^{\circ}$ Brix) & $\mathrm{AT}^{1}$ & Cor L* & Cor a* & Cor b* \\
\hline Mínimo & 22,00 & 3,78 & 5,20 & 1,20 & 59,56 & $-7,13$ & 12,19 \\
\hline Máximo & 151,13 & 4,50 & 7,10 & 3,50 & 77,35 & 0,78 & 43,35 \\
\hline Média & 119,63 & 4,17 & 6,07 & 2,31 & 70,84 & $-2,98$ & 24,61 \\
\hline Mediana & 139,05 & 4,14 & 5,83 & 2,20 & 72,65 & $-2,93$ & 23,69 \\
\hline Variância & 1506,06 & 0,05 & 0,43 & 0,43 & 27,28 & 4,04 & 72,13 \\
\hline Desvio Padrão & 38,81 & 0,22 & 0,65 & 0,65 & 5,22 & 2,01 & 8,49 \\
\hline $\mathrm{CV}(\%)$ & 32,44 & 5,30 & 10,74 & 28,31 & 7,32 & $-67,45$ & 34,51 \\
\hline
\end{tabular}

O teor de sólidos solúveis é um índice de qualidade e sua composição, principalmente, de açúcares e ácidos determinam o sabor do fruto. Na avaliação dos frutos, foi encontrada média de 6,07 para sólidos solúveis, abaixo de outros encontrados na literatura (BELTRÃO; SOUZA; SILVA, 2014; SÁTIRO et al., 2017). Uma vez que o teor de sólidos solúveis se eleva com o avanço da maturidade, esses valores podem evidenciar que a maior parte dos frutos não apresentava maturação muito acentuada.

A acidez titulável representada pelo teor de ácido cítrico, também influencia o sabor do fruto, sendo a média obtida neste trabalho de 2,31.Silva et al. (2012) encontraram média variando entre 0,30 a 0,39 para frutos "de vez" e "maduros", respectivamente, enquanto Canuto et al. (2010) encontraram teor de acidez de 3,2\%, enquanto Maciel (2011) encontrou 6,31\%. Esses resultados evidenciam que, embora Silva et al. (2012) tenham afirmado que o fruto de noni apresenta baixa acidez quando comparado com outros frutos como o abacaxi, umbu-cajá e jabuticaba, a variação observada entre diversos trabalhos tem sido muito grande, o que requer mais estudos sobre esse fruto.

A coloração da casca do fruto está relacionada com a maturação e com as condições climáticas durante o período de produção. A luminosidade ( $\left.L^{*}\right)$ média dos frutos avaliados foi elevada $(70,84)$ quando comparada com os valores encontrados por Beltrão, Souza e Silva (2014), em frutos com estágios de maturação semi-maduro $(26,98)$ e maduro $(31,30)$. Os valores negativos obtidos para $a^{*}$, indica a tendência da cor na maioria dos frutos para a intensidade verde. Os baixos valores de a* e elevados valores b*, em relação à casca, caracterizam a tendência para a cor amarela.

\section{CONCLUSÃO}

Os aspectos físico-químicos dos frutos indicam potencial do fruto para o consumo in natura e industrialização.

\section{REFERÊNCIAS}

[1] BELTRÃO, F.A.S; SOUZA, K.P.; SILVA, J.M.Caracterização de noni (Morinda citrifolia L.) Revista de Engenharia Ambiental, Espírito Santo do Pinhal, v. 11, n. 1, p. 38-44, 2014.

[2] CANUTO, G. A. B; XAVIER, A. A. O; NEVES, L. C; BENASSI, M. T; Caracterização físico-química de polpas de frutos da Amazônia e sua correlação com a atividade anti-radical livre. Revista Brasileira de Fruticultura, Jaboticabal,v.32, n.4, 2010.

[3] CAVALINI, F.C. Fisiologia do amadurecimento, senescência e comportamento repiratório de goiabas 'Kumagai' e 'Pedro Sato'. 2008. 90f. Tese (Doutorado em Fisiologia e Bioquímica de plantas), Universidade de São Paulo, Piracicaba, 2008.

[4] CHITARRA MIF, CHITARRA AB. Pós-colheita de frutos e hortaliças: fisiologia e manuseio. 2. ed. Lavras: UFLA; 2005. p. 785.

[5] CORREIA, A. A. S. Maceração enzimática da polpa do noni (Morinda citrifolia L.). 2010. 105f. Dissertação (Mestrado em Tecnologia de Alimentos) - Universidade Federal do Ceará, Fortaleza, 2010.

[6] DANTAS, R. L.; ROCHA, A. P. T.; ARAÚJO, A. S.; RODRIGUES, M. S. A.; MARANHÃO, T. L. Perfil da qualidade de polpas de frutas comercializadas na cidade de Campina Grande/PB. Revista Verde de Agroecologia e Desenvolvimento Sustentável, v.5, n.5, p. 61 - 66, 2010.

[7] INMET. INSTITUTO NACIONAL DE METEOROLOGIA. Disponível em:. Acesso em: 05 de outubro de 2018. 
[8] MACIEL, F. P. Análise físico-química da polpa do fruto de noni (Morinda citrifolia l.) do município de Monte Negro/RO. Ariquemes, 2011. Monografia

[9] SÁTIRO, L. S.;COSTA, F. B.; LIMA, E. Q.; NASCIMENTO, A. M.;SANTIAGO, M. M.; SANTOS, K. P.Características físicas e químicas de frutos de Noni colhidos em dois estádios de maturação. Disponível em: https://www.researchgate.net/publication/320177274_Caracteristicas_fisicas_e_quimicas_de_frutos_de_Noni_colhido s_em_dois_estadios_de_maturacao [acessado em Oct 01 2018].

[10] SILVA, L. R..; MEDEIROS, P. V. Q. D.; ,EITE, G. A.; SILVA, K. J. P.; MENDONÇA, V.; SOUSA, J. A. D.; SILVA, M. S. Caracterização do fruto de Morinda citrifolia L. (noni).Revista Cubana Plantas Medicinais,v.17, n.1, p.93-100, 2012.

[11] SILVA, L. R., PONTES, C. A., AGUIAR, A. L. L. de, CISNE, M. F., SILVA, E. O.Qualidade de frutos de noni (Morinda citrifolia L.) cultivados em Trairi-CE. Revista Cubana de Plantas Medicinais, v.18, n.1, p.100-108, 2013.

[12] SOUSA, J.A.; AQUINO, A.R.L.; FREIRE, F.C.O.; SILVA NETO, P.A.F. Produção de mudas de noni (Morinda citrifolia L.).Fortaleza, CE:Embrapa Agroindústria Tropical, 2010. (Comunicado Técnico online 157). ISSN 1679-6535

[13] TOMBOLATO, F.C.A; BARBOSA, W.; HIROCE, R..Noni: frutífera medicinal em introdução e aclimatação no Brasil. Informações técnicas: O agronômico, Campinas. 2005;57(1):20-1. 


\title{
Capítulo 8
}

\section{Estudo da capacidade antirradicalar do extrato etanólico do eucalipto}

\author{
Amanda Lima Cunha \\ Monizy da Costa Silva \\ Aldenir Feitosa dos Santos \\ João Victor Laurindo dos Santos \\ Ingrid Sofia Vieira de Melo \\ Karla T. M. Gollner-Reis
}

Resumo: Desde a antiguidade o uso de produtos naturais como fonte de medicamento é bastante utilizado, destacando assim a importância do estudo do poder terapêutico de fontes vegetais como o eucalipto. Deste modo, o presente trabalho tem como objetivo avaliar por testes quantitativos e qualitativos a capacidade antioxidante e identificação de compostos bioativos do extrato etanólico das folhas do eucalipto. Para obtenção dos resultados foram realizado os seguintes ensaios laboratoriais: captura do radical livre DPPH, triagem fitoquímica, tiocianato férrico e quantificação de teor de fenóis totais. Por meio do teste de DPPH foi identificado que a amostra na concentração de $200 \mu \mathrm{g} / \mathrm{ml}$ alcançou-se 94,96\% de atividade antioxidante. Quanto ao teste de inibição do peróxido de hidrogênio, percebeu-se que o extrato vegetal apresentou similaridade com o antioxidante sintético BHA. Identificou-se metabólitos secundários como taninos flabotênicos, esteróides e saponinas e ainda obteve-se quantitativamente o teor de fenóis totais equivalentes a 0,121 mg EAG/g de extrato seco. Deste modo, evidencia-se a importância do estudo do extrato etanólico do eucalipto.

Palavras-chave: Amostra vegetal, antioxidantes, radicais livres, antioxidante. 


\section{INTRODUÇÃO}

Nos últimos anos, vários setores da sociedade, principalmente os de saúde pública, estão dando maior ênfase a questões relacionadas com as espécies reativas eseu envolvimento com algumas fisiopatologias, uma vez que afirmam que o estresse oxidativo está associado com diversas doenças, como vários tipos de câncer, doenças cardiovasculares e inflamatórias (SILVA; FREITAS; RODRIGUES, 2019).

Segundo Mosca; Sanches e Comune (2017), os radicais livres são átomos ou moléculas altamente reativos, que possuem número ímpar de elétron e são produzidos naturalmente no organismo. Estes são gerados através do próprio mecanismo do corpo ou de fatores ambientais. Para adquirir sua estabilidade os oxidantes atacam as moléculas vizinhas influenciando na oxidação das mesmas.

Para os seres vivos manterem o metabolismo e funcionamento da célula inalterado é necessário que ocorra um balanceamento entre as defesas antioxidante e os efeitos tóxicos causados pelas espécies oxidantes. No entanto, se esse efeito for comprometido pelo excesso da quantidade de espécies reativas ou a falta de antioxidantes, ou ainda ambas as condições, ocasiona o estresse oxidativo (CAMPOS \& LEME, 2018).

Os antioxidantes são compostos capazes de retardar ou neutralizar a velocidade das reações oxidativas que ocorrem no organismo, inibindo a ação das espécies oxidantes, prevenindo o aparecimento de doenças e contribuindo com uma maior longevidade (SILVA et al., 2017).

Nos últimos anos, o alvo das pesquisas em todo o mundo está sendo os antioxidantes naturais encontrados em alimentos ricos em gorduras saturadas, uma vez que estes compostos bioativos possuem uma enorme variedade de nutrientes, vitaminas e compostos químicos que são formados a partir do metabolismo secundário dos vegetais, estando presentes em maior quantidade nas frutas e hortaliças (AGUIAR, 2017).

Antioxidantes naturais são pequenas moléculas que se encontram presentes nos nutrientes em quantidade relativamente pequena, e estas por sua vez, possuem a capacidade de reduzir a velocidade das reações oxidativas dos compostos lipídicos que estão presentes em alguns produtos, inibindo a ação das espécies reativas (ROMANI; MARTINS \& SOARES, 2017).

A presente pesquisa tem por objetivo avaliar a atividade antioxidante do extrato etanólico da folha do Eucalyptus spp., utilizando os métodos de captura do DPPH (2,2-difenil-1-picril hidrazil) quantitativo, Tiocianato férrico (FTC), Compostos Fenólicos e Triagem Fitoquímica.

\section{MATERIAL E MÉTODOS}

\subsection{PREPARO DO EXTRATO}

As folhas da espécie Eucalyptus spp. foi triturada e em seguida realizou o processo de maceração, onde as folhas foram emergidas em etanol $99 \%$, havendo o processo de troca do solvente a cada 48 horas, durante 7 dias. Logo após, o solvente filtrado foi levado ao rotoevaporador e obtido o extrato seco (SANTOS et al., 2019).

\subsection{ANÁLISE FITOQUÍMICA}

Para a realização da etapa de triagem fitoquímica tomou-se como base a metodologia proposta por Cunha et al. (2020), a fim de realizar prospecção dos seguintes aleloquimicos: fenóis, taninos pirógalicos, taninos flobafênicos, antocianina e antocianidina, flavonas, flavonóis, xantonas, chalconas, auronas, flavononois, leucoantocianidinas, catequinas, flavononas, flavonois, xantonas, esteróides, triterpenóides e saponinas; tais constituintes forma idenficados a partir da adição reagentes como hidróxido de sódio, ácido clorídrico, ácido sulfúrio, anidrido acético e cloreto férrico. A triagem fitoquímica toma como base para identificação dos metabólitos secundários a mudança de coloração e/ou formação precipitado.

\subsection{TESTE QUANTITATIVO DPPH}

0 teste de captura do radical DPPH tem por objetivo avaliar o potencial antioxidante, por meio da captura do radical livre por uma espécie vegetal. A reação entre uma espécie antioxidante e o radical DPPH é perceptível pela mudança de coloração do púrpura ao amarelo (CUNHA et al., 2020). 
A metodologia seguida foi de acordo com a descrita por Cunha et al. (2020). Para realização do teste foram pesados 0,0020 g do extrato etanólico e diluído em $20 \mathrm{ml}$ de etanol 99\%. Após a diluição foram realizadas soluções testes nas concentrações de 50,100, 150, 200 e $250 \mu \mathrm{g} / \mathrm{ml}$. Para cada solução teste foram realizadas, em triplicata, soluções contendo $2,5 \mathrm{ml}$ das soluções testes e $1 \mathrm{ml}$ da solução de DPPH. Para cada concentração também foi realizado o branco (em triplicata) contendo 2,5 ml da solução teste e $1 \mathrm{ml}$ de etanol 99\%. Além do negativo (em triplicata) contendo 2,5 ml de etanol 99\% e $1 \mathrm{ml}$ da solução de DPPH.

As soluções foram incubadas, em ambiente escuro, durante minutos. Decorrido o tempo foi realizada a leitura das soluções em espectrofotômetro UV-VIS 2000 a 518nm. As absorbâncias obtidas foram convertidas em atividade antioxidante.

0 percentual antioxidante foi calculado por meio da equação: AA0\%= (100-(Absorbância A - Absorbância B)x100))/Absorbância C.

\subsection{TIOCIANATO FÉRRICO (FTC)}

A análise tomou como base a metodologia descrita por Santos et al. (2019). 0 teste tem por objetivo analisar a capacidade de extratos vegetais em inibir a peroxidação lipídica. 0 teste foi realizado durante 5 dias, onde a cada 24 horas era realizada a leitura da solução estoque, a qual ficou em estufa a $50^{\circ} \mathrm{C}$ durante os 5 dias.

A solução teste continha amostra vegetal (extrato etanólico da folha do eucalipto), água destilada, solução de tampão fosfato e ácido linoleico. A solução para leitura foi realizada em triplicata, contendo 0,1 ml da solução estoque, $0,1 \mathrm{ml}$ da solução de cloreto férrico, $0,1 \mathrm{ml}$ da solução de tiocianato de amônia e 9,75 ml de etanol 75\%.

Após o preparo das soluções realizou-se a leitura em espectrofotômetro UV-VIS 2000 a 500nm. Com a obtenção das absorbâncias, essas foram convertidas em percentual de inibição.

Vale ressaltar que para o teste foi realizado o preparo do controle positivo que continha o BHA. Para o controle positivo foi realizado o mesmo procedimento realizado com o extrato vegetal.

\subsection{COMPOSTOS FENÓLICOS - FOLIN}

Para quantificação do teor de fenóis totais foi construída uma curva de calibração de ácido gálico, com a seguinte equação e coeficiente de reprodutibilidade, respectivamente, $Y=1,2892 x+0,0591$ e $R^{2}=0,99$, na qual seus valores foram interpolados com as absorbâncias do extrato vegetal. Para a realização do teste foi utilizado o reagente folin-ciocalteau. Os valores foram expressos em miligramas equivalentes de ácido gálico (mg EAG/ g do extrato seco), para realização dos teste seguiu a metodologia descrita por Barros et al. (2018).

\section{RESULTADOS E DISCUSSÃO}

Dentre os efeitos biológicos, dos metabólitos secundários, há redução de doenças cardiovasculares, inibição do desenvolvimento de alguns tipos de tumores malignos, reposição hormonal, estimulação do sistema imunológico, ação cicatrizante, antisséptica e antioxidante (PEREIRA e CARDOSO, 2012).

Através do teste qualitativo de prospecção preliminar, identificou-se os seguintes metabólitos secundários: taninos flobatênicos, esteróides e saponinas (Figura 1). Tais metabólitos possuem propriedades biológicas que confirmam o uso terapêutico do eucalipto. Enquanto Lourido et al. (2018) ao avaliarem o extrato etanólico de Aniba parviflora identificaram a presença de terpenóides e flavonóides. A diferença de concentração de compostos bioativos podem variar de espécie para espécie, como também pela variação de fatores abióticos que influênciam diretamente na concentração e na produção de diferentes classes de metabólitos (GOBBO-NETO e LOPES, 2007). 
Figura 1 - Resultado da prospecção preliminar realizada com o extrato etanólico das folhas do eucalipto

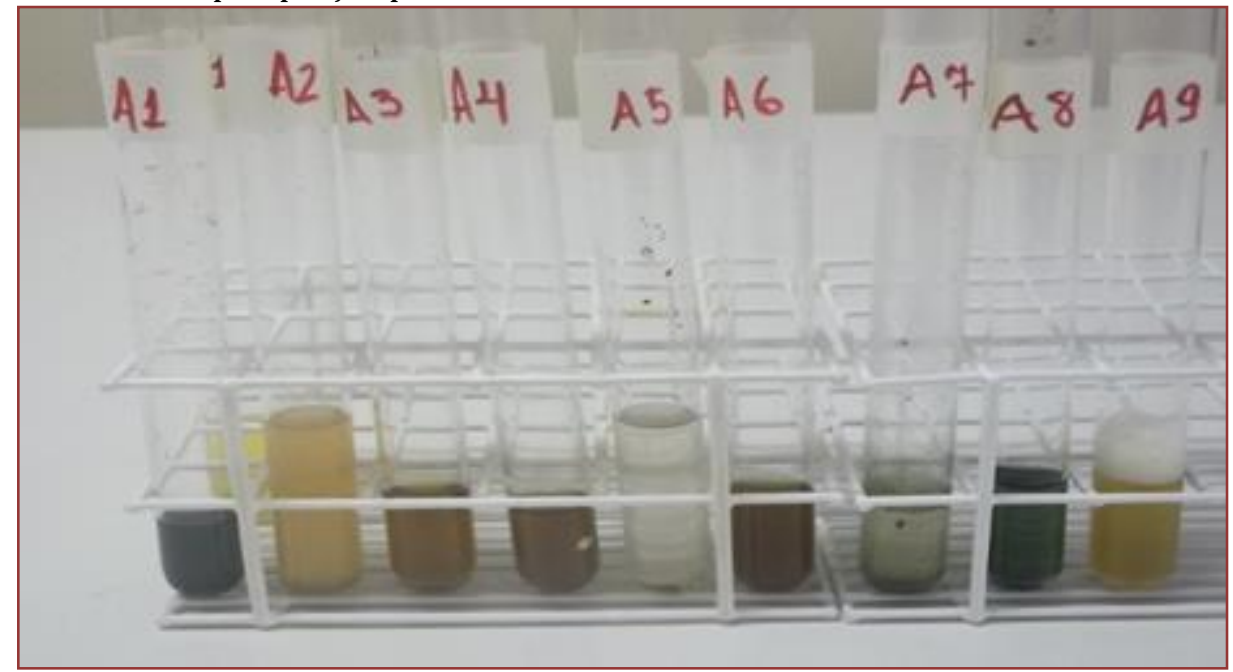

Fonte: (Dados da pesquisa).

Por meio do teste quantitativo de DPPH foi testado o extrato etanólico da folha do Eucalyptus ssp. nas concentrações de 250, 200, 150,100,50 $\mathrm{g} / \mathrm{mL}$ na presença de DPPH para avaliar a capacidade de inibição deste radical. Os resultados obtidos constam no gráfico 1.

Os dados do gráfico 1 foi submetido a análise estatística para a obtenção da equação da reta e do seu coeficiente de determinação $\left(R^{2}\right)$. Foi observado que o resultado do valor de $R^{2}$ foi próximo de 1,0 , o que indica que a equação de reta gerada reproduz com eficiência o comportamento antioxidante da amostra avaliada.

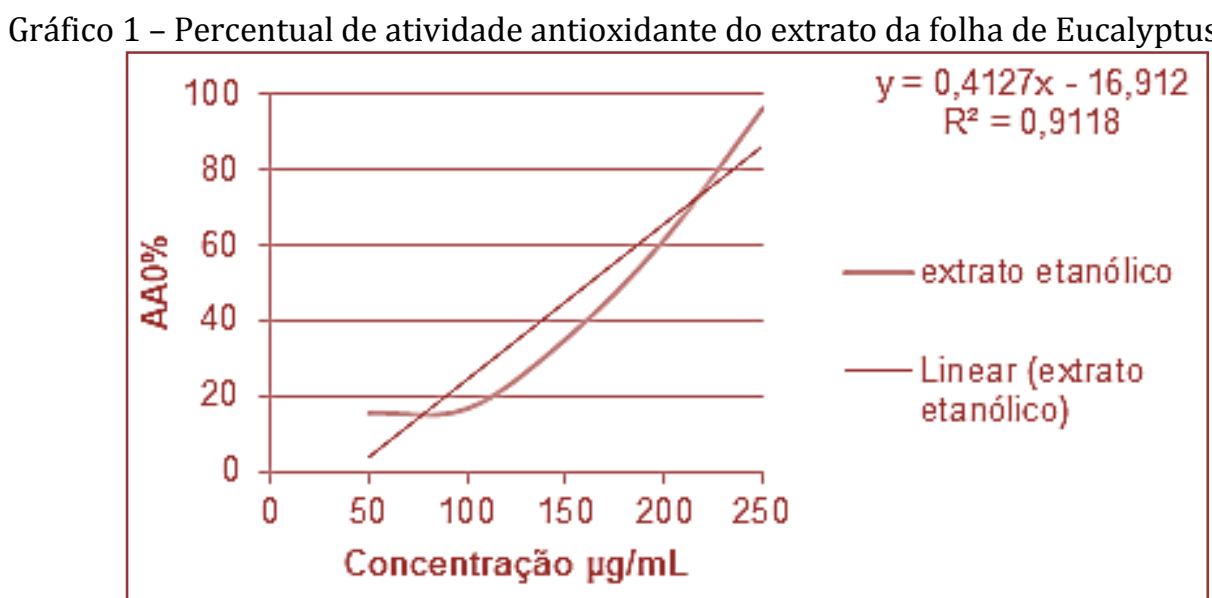

Fonte: (Dados da pesquisa).

Fonsêca (2019), ao estudar as folhas de Myrcia hirtiflora DC. Por meio do teste de captura do DPPH, verificou que a espécie alcanou $50 \%$ de percentual antioxidante na concentração de $250 \mu \mathrm{g} / \mathrm{mL}$. Enquanto a espécie avaliada, nesta pesquisa, na concentração de $200 \mu \mathrm{g} / \mathrm{mL}$ atinge um percentual de $94,97 \%$, demonstra que por meio do teste quantitativo de DPPH possui maior eficiência que outras espécies já citadas na literatura. 
0 alto potencial antioxidante da amostra valiada, pode também ser explicado pela sua alta concentração compostos fenólicos totais. Segundo Silva et al. (2010), os compostos fenólicos conferem atividade antioxidante as espécies vegetais. Por meio do teste de folin-ciocalteau, o extrato etanólico das folhas de Eucalyptus ssp. apresentou um teor de 182,61 mgEAG/g de extrato, valor superior apresentados na literatura por amostra de mesma espécies. Cidres (2018) ao avaliar as folhas do eucalipto identificou um teor de 135,50 mgEAG/g de extrato.

Por meio da análise de percentual de inibição do peróxido de hidrogênio, o extrato etanólico das folhas de eucalipto, apresentou um percentual entre 76 a 144,11\%, valor superior a citadas na literatura, onde Fonsêca (2019), afirma que as folhas de Myrcia hirtiflora DC. Atingiu valores entre 25 a $70 \%$ de inibição da peroxidação lipídica.

\section{CONCLUSÃO}

Portanto, através dos dados colhidos nessa pesquisa, percebeu-se a importância da continuidade sobre estudos mais aprofundados sobre a espécie citada, visando confirmar os compostos fenólicos presentes no extrato etanólico e sua utilização, possibilitando com isso, sua utilização nos diversos setores industriais, principalmente no setor farmacêutico, na produção de novos produtos que possam inibir ou retardar as reações oxidativas, aumentando o grau de prevenção de patologias e consequentemente preservando a saúde humana.

\section{REFERÊNCIAS}

[1] AGUIAR, J. M. V. Determinação de compostos bioativos em frutas e vegetais consumidos na Região Autónoma da Madeira. Dissertação - UNIVERSIDAE DA Madeira, Funchal - Portugal. 2017.

[2] CAMPOS, M. T. G.; LEME, F. O. P. Estresse oxidativo e diagnóstico laboratorial. Revista PUBVET, vol. 12, n. 1, p. 1-8, 2018.

[3] CIDRES, E. S. S. A. Óleo essencial das folhas e fruto do eucalipto: avaliação da atividade antimicrobiana e da atividade antioxidante. Dissertação - Escola Superior de Tecnologia e Gestão. Braga, 2018.

[4] CUNHA, A. L.; et al. Chemical characterization of the species Raphanus sativus L. under different conditions of fertilization and water stress conditions. Acta Brasiliensis, [S.l.], v. 4, n. 1, p. 53-59, jan. 2020.

[5] FONSÊCA, M.M. L. B. Avaliação da atividade antioxidante da Myrcia hirtiflora DC. em ensaios in vitro e in vivo. Monografia Faculdade Pernabucana de Saúde. Recife - PE, 2019.

[6] GOBBO-NETO, L.; LOPES, N. P.. Plantas medicinais: fatores de influência no conteúdo de metabólitos secundários. Revista Química Nova, v. 30, n.2, p. 374-381, 2007. Disponível: http://quimicanova.sbq.org.br/imagebank/pdf/Vol30No2_374_25RV05289.pdf. Acesso em: 19 de jun. de 2020.

[7] LOURIDO, K. A.; et al. Análise fitoquímica e atividade antifúngica do extrato etanólico do resíduo de folhas e madeira de macacaporanga. Revista Agroecossistemas, vol. 10, n. 2, p. 177-186, 2018.

[8] MOSCA, S. S.; SANCHES, R. A.; COMUNE, A. C. A importância dos antioxidantes na neutralização dos radicais livres: uma revisão. Revista Saúde em Foco, n.9, 2017. Disponível em: < http://portal.unisepe.com.br/unifia/wpcontent/uploads/sites/10001/2018/06/063_radicaislivres.pdf>. Acessado em 19 de jun. de 2020.

[9] PEREIRA, R. J.; CARDOSO, M. G. Metabólitos secundários vegetais e benefícios antioxidantes. Journal of Biotechnology and Biodiversity. v.3, n. 4, p. 146-152. 2012. ISSN-2179-4804, 2012. Disponível em: https://www.todafruta.com.br/wpcontent/uploads/2016/09/Metab\%C3\%B3litos-secund\%C3\%A1rios-ARTIGO.pdf. Acesso em: 19 de jun. 2020.

[10] ROMANI, V. P.; MARTINS, V. G.; SOARES, L. A. S. Oxidação lipídica e compostos fenólicos como antioxidantes em embalagens para alimentos. Revista Vetor, vol.27, n. 1, p.38-56, 2017.

[11] BARROS, R. P.; et al. Bioactivity and phenolic composition of extracts of noni (Morinda citrifolia L., Rubiaceae) in tomato moth (Tuta absoluta Meyrick, 1917) (Lepidoptera: Gelechiidae). African Journal of Agricultural Research, vol. 13, p. 2063-2069, 2018.

[12] SANTOS, A. F.; et al. Análise do potencial antioxidante de três espécies vegetais da família Fabaceae. In: Alan Mario Zuffo. (Org.). As Regiões Semeáridas e suas Especificidades. 1ed.: Antonella Carvalho de Olivera, 2019, p. 70-84.

[13] SILVA, C. B.; et a al. A importância da ação antioxidante de óleos essenciais em benefício da saúde. Diversitas Journal, vol. 2, n. 1 , p. $52-55,2017$.

[14] SILVA, C.; FREITAS, A. R.; RODRIGUES. Espécies reativas e a ação dos antioxidantes. Revista Saúde em Foco, n.11, 2019. Disponível em: < http://portal.unisepe.com.br/unifia/wp-content/uploads/sites/10001/2019/12/ESP\%C3\%89CIES-REATIVAS-EA-A\%C3\%87\%C3\%830-DOS-ANTIOXIDANTES.pdf>. Acessado em 19 de jun. de 2020. 


\section{Capítulo 9}

Atividade fungitóxica de extratos vegetais de plantas nativas do bioma Caatinga sobre colletotrichum musae, agente causal da antracnose em banana

Ranoel José de Sousa Gonçalves

Maria Zilderlania Alves

Maria Lúcia da Silva Cordeiro

Isabella da Rocha Silva

Eudocia Carla de Araújo

Lucas Rodolfo Inácio da Silva

José Renato Guimarães

Resumo: 0 presente trabalho objetivou avaliar in vitro o efeito fungitóxico de diferentes concentrações de extratos vegetais de plantas nativas do bioma Caatinga sobre o crescimento micelial do fungo Colletotricum musae agente causal da antracnose em banana. Os extratos vegetais hidroetanólicos foram obtidos a partir da parte aérea das plantas aroeira (Astronium urundeuva [Fr. All.] Engl.), angico (Anadenanthera colubrina var. cebil), alecrim-do-campo (Lippia microphylla Cham), e catingueira [Poincianella pyramidalis (Tul.) L. P. Queiroz]. Após a incorporação dos extratos em meio BDA (batata, dextrose e agar), nas concentrações de 25\%,50\%, 75\% e 100\% , contendo a testemunha apenas o meio de cultivo, avaliou-se a inibição do crescimento micelial pela média de duas medidas, diariamente opostas do diâmetro das colônias, às 48, 72, 96 e 120 horas após a instalação do experimento. Os resultados obtidos para os testes in vitro demonstraram que o extrato de alecrim-do-campo, em todas as concentrações testadas foi o mais efetivo, inibindo o crescimento do patógeno em 100\%. Em relação aos demais extratos, de modo geral, reduções significativas sobre o diâmetro das colônias fúngicas foram constatadas apenas quando se empregou a maior concentração em estudo.

Palavras-chave: fungos; controle alternativo; pós-colheita; patógeno. 


\section{INTRODUÇÃO}

A banana (Musa sp.),é explorada na maioria dos países tropicais, estando entre os frutos mais produção e consumidos do mundo. O Brasil, quinto maior produtor mundial da fruta, destaca-se com uma produção de 7.303.967 toneladas de frutos ao ano, possuindo a maior área plantada do total mundial (IBGE, 2013).

Embora esteja entre os maiores produtores mundiais de banana, a participação do Brasil no mercado internacional ainda é pouco expressiva, parte disso devido à ocorrência de doenças pós-colheita, responsáveis por consideráveis danos na produção, sendo os fungos causadores da maioria das doenças que afetam a fruta.

Entre as doenças fúngicas pós-colheita as quais a banana está sujeita, a antracnose, causada pelo fungo Colletotrichum musae, destaca-se como uma das principais. Esta doença compromete a qualidade dos frutos, uma vez que o estabelecimento do patógeno causador provoca o escurecimento e necrose do tecido, tornando-os imprestáveis para o consumo (CORDEIRO et al., 2005).

Para o controle da antracnose o método mais utilizado é o químico, realizado por meio da aplicação de fungicidas aos frutos. Entretanto, sabe-se que o uso intensivo desses agentes tem causado graves impactos ao ambiente e à saúde humana. Assim, a pesquisa fitopatológica tem se intensificado buscando utilizar compostos obtidos a partir de plantas como uma alternativa sustentável, viável e acessível para o tratamento da antracnose.

Portanto, o presente trabalho objetivou avaliar in vitro o efeito fungitóxico de diferentes concentrações de extratos vegetais de plantas nativas do bioma Caatinga sobre o crescimento micelial do fungo Colletotricum musae, agente causal da antracnose em banana.

\section{MATERIAL E MÉTODOS}

\subsection{ISOLAMENTO E CULTIVO DO PATÓGENO}

O isolado fúngico de Colletotrichum musae foi obtido pela utilização do método de isolamento indireto a partir de bananas "cv. Prata", com sintomas característicos da antracnose. Após o isolamento e identificação do patógeno, foram obtidas culturas puras em placas de Petri contendo meio de cultura BDA (batata dextrose ágar) e incubados em condições ambiente por sete dias, sob fotoperíodo de 12 horas (25 $\pm 2{ }^{\circ} \mathrm{C}$ e UR de $65 \pm 1 \%$ ). Após a obtenção da cultura pura, a mesma foi conservada em câmara climatizada BOD a $4 \stackrel{\circ}{\circ}$ para posterior utilização.

\subsection{OBTENÇÃO DOS EXTRATOS HIDROETANÓLICOS DE ESPÉCIES VEGETAIS DA CAATINGA}

Foram utilizadas quatro espécies de plantas da Caatinga para os testes com os extratos hidroetanólicos, sendo estas: aroeira (Astronium urundeuva [Fr. All.] Engl.), angico (Anadenanthera colubrina var. cebil), alecrim-do-campo (Lippia microphylla Cham), e catingueira [Poincianella pyramidalis (Tul.) LP Queiroz]. Na preparação dos extratos foram utilizados $100 \mathrm{~g}$ do material vegetal (folhas e ramos). 0 material foi lavado em água corrente, desinfetado com hipoclorito de sódio a 1\% durante 15 minutos e em seguida lavado com água destilada. As folhas e os ramos foram triturados em liquidificador, contendo $250 \mathrm{~mL}$ de água destilada esterilizada (ADE) e $250 \mathrm{~mL}$ de álcool etanólico, colocados em um recipiente de vidro fechado e submetidos por um período de 96 horas, para a extração dos princípios ativos. Posteriormente, os extratos foram filtrados em camada dupla de gaze, e os líquidos resultantes filtrados através de papel de filtro esterilizado e mantidos em recipiente aberto, durante 72 horas. Após esse período, o material foi submetido à radiação ultravioleta por 30 minutos em câmara de fluxo laminar, acondicionado em frascos de vidro tipo âmbar previamente esterilizados e armazenados em refrigerador a $4{ }^{\circ} \mathrm{C}$.

\subsection{TESTE “IN VITRO” DOS EXTRATOS DE PLANTAS NATIVAS DA CAATINGA AO C. MUSAE}

Para este ensaio, alíquotas dos extratos das diferentes espécies vegetais foram adicionadas ao meio de cultura BDA, fundente $\left(45^{\circ} \mathrm{C}\right)$ nas concentrações de 25, 50, 75 e 100\%. Em seguida os meios com as diferentes concentrações obtidas foram transferidos para placas de Petri de $9 \mathrm{~cm}$ de diâmetro. Após a solidificação, com auxílio de um furador, discos de $5 \mathrm{~mm}$ de diâmetro do fungo foram retirados de colônias do fungo após sete dias de crescimento e transferidos individualmente no centro de cada uma das placas componentes de cada concentração, as quais foram vedadas com filme plástico e mantidas em 
temperatura ambiente sob fotoperíodo de 12 horas durante 5 dias. A testemunha consistiu do disco de 5 $\mathrm{mm}$ de diâmetro do fungo, cultivado em meio BDA em placas de Petri de $9 \mathrm{~cm}$ de diâmetro. 0 efeito das diferentes concentrações dos extratos vegetais sobre o crescimento micelial foi avaliado às 48, 72, $96 \mathrm{e}$ 120 horas após a inoculação, por meio de medições do diâmetro da colônia fúngica, em dois eixos ortogonais (media de duas medidas diametricamente opostas), com o auxílio de um escalimetro, e comparando com o controle que não recebeu extrato, sendo posteriormente calculada a média dos resultados obtidos.

O delineamento experimental utilizado foi o inteiramente casualizado com quatro repetições por tratamento. Os tratamentos foram arranjados em um esquema fatorial $4 \mathrm{x} 4+1$ (quatro extratos vegetais $\mathrm{x}$ quatro concentrações + testemunha) e os dados obtidos nesse estudo foram submetidos a analise de variância, sendo as médias comparadas pelo teste de Scott-Knott ao nível de 5\% de probabilidade, com o auxílio do programa estatístico SISVAR versão 4.0 (FERREIRA, 2000).

\section{RESULTADOS E DISCUSSÃO}

Os resultados da avaliação in vitro dos extratos vegetais sobre crescimento micelial de $C$. musae revelaram que alecrim-do-campo (Lippia microphylla Cham.) foi o produto mais efetivo, inibindo em $100 \%$ o crescimento micelial do patógeno em todas as concentrações testadas $(25,50,75$ e $100 \%)$ para todas as variáveis respostas, o que evidencia o elevado potencial fungitóxico desta espécie.

A redução do crescimento micelial de patógenos, utilizando extratos de alecrim-do-campo foi evidenciada anteriormente em estudos realizados por Pinheiro (2011), que relata a inibição total in vitro do crescimento micelial do fungo Moniliophtora perniciosa pelo extrato das folhas de alecrim-do-campo (Lippia microphylla) em concentrações abaixo de $4000 \mu \mathrm{g} / \mathrm{mL}$. Recentemente, Barros et al. (2012) ao avaliarem o efeito de diferentes concentrações do extrato etanólico desta espécie contra fitopatógenos de diferentes classes, Pythium sp., Colletotrichum sp., Moniliophthora perniciosa, Cercosporidium sp., Curvularia sp. e Sclerotium sp. demonstraram a total inibição de todos os micro-organismos quando utilizada a concentração de 4000 ppm, dados estes que confirmam a eficiência do extrato.

0 efeito do extrato de angico (Anadenanthera colubrina var. cebil) sobre Colletotrichum musae, não foi observado quando este foi submetido na concentração $25 \%$, não diferindo estatisticamente da testemunha. No entanto, nas concentrações 50, 75 e 100\%, este extrato demonstrou desempenho superior ao da testemunha e aos extratos de aroeira e catingueira para todas as variáveis respostas. Efeitos mais significativos de inibição do crescimento de Colletotrichum musae foram obtidos quando o fungo foi exposto ao extrato de angico na concentração 100\%, visto que para esta concentração, este não diferiu do extrato de melhor desempenho, o alecrim-do-campo em todos os momentos de avaliação, exceto às 120 horas.

0 efeito do extrato de angico observado neste ensaio é superior ao relatado por Lima et al. (2010) que ao testarem o efeito do extrato etanólico das folhas de angico (Anadenanthera colubrina) sobre o fungo Lasiodiplodia theobromae, obtiveram um controle do crescimento de apenas 9,12\%. No entanto, o extrato etanólico do angico (Anadenanthera colubrina) é citado ainda por Costa et al. (2013) como tendo atividade contra a bactéria Enterococcus faecalis.

Quando o Colletotrichum musae foi exposto ao extrato de aroeira (Astronium urundeuva), foi observado para todas as variáveis respostas um crescimento micelial do fungo significativamente superior ao da testemunha, nos tratamentos contendo o extrato na concentração de $25 \%$, pressupondo que possam existir substâncias nas folhas e talos da planta que estimulam ou favoreçam o crescimento do fungo. Este favorecimento no crescimento de fitopatógenos também é relatado por Venturoso (2009), que destaca o estímulo ao crescimento de Penicillium sp. pelos extratos de cavalinha (Equisetum sp.) e jabuticaba (Myrcia cauliflora). De acordo com o autor, o extrato de cavalinha (Equisetum sp.) proporcionou maior crescimento do fungo até o sexto dia de incubação. 
Desconsiderando a concentração de $25 \%$, para o extrato de aroeira, o fungo teve seu crescimento proporcionalmente inibido conforme o aumento da concentração de extrato testada, contudo, o mesmo inibiu apenas parcialmente o crescimento de $C$. musae, alcançando em todos os dias de avaliação diâmetros da colônia consideráveis, demonstrando a baixa eficiência desse extrato quando comparado ao obtido do alecrim-do-campo, que inibiu em 100\% o crescimento do fungo, em meio BDA, já na concentração de $25 \%$.

Embora reduções consideráveis do diâmetro das colônias de $C$. musae não tenham sido determinadas na presente pesquisa para o extrato da aroeira, os resultados encontrados corroboram outros que encontraram atividade antimicrobiana em diferentes concentrações do extrato hidroalcólico das folhas de aroeira (Astronium urundeuva) contra bactérias e fungos (ALVES et al, 2009; PINHO et al, 2012).

Observou-se para o extrato da catingueira (Poincianella pyramidalis), que este esteve presente no mesmo grupo do extrato da aroeira na concentração de $25 \%$, não diferindo estatisticamente deste, estimulando o crescimento do patógeno para todas as variáveis respostas. Este extrato apresentou efeito inibitório sobre o crescimento do Colletotrichum musae, apenas quando empregado na concentração de $100 \%$ quando foi constatado um lento desenvolvimento do Colletotrichum musae.

Pode-se afirmar que para este estudo, o extrato de catingueira foi o extrato que apresentou menor efeito inibitório sobre o crescimento micelial do C. musae. Entretanto, estudos anteriores constataram o potencial desta espécie no controle de diversos micro-organismos, como evidenciado por Saraiva et al. (2012), ao relatarem a atividade dos extratos metanólicos da folha, casca do caule e flor da catingueira (Poincianella pyramidalis) contra Escherichia coli, Enterococcus faecalis, Klebsiella pneumoniae, Salmonela sp., Staphylococcus aureus e Pseudômonas aeruginosa.

Com base no diâmetro médio da colônia fúngica verificou-se o efeito positivo dos extratos utilizados, uma vez que eles inibiram em menor ou maior grau o crescimento micelial do Colletotrichum musae. Foi também observada uma redução significativa do crescimento do fungo com o aumento das concentrações dos extratos das espécies vegetais testadas, visto que menores diâmetros da colônia foram obtidos, com exceção do alecrim-do-campo, apenas quando empregadas maiores concentrações.

Resultados semelhantes aos relatados nesse estudo foram observados anteriormente por Celoto (2005) que avaliando o efeito do extrato de melão-de-São-Caetano (Momordica charantia L.) observou uma redução do crescimento micelial deste mesmo fungo com o aumento das concentrações testadas. De acordo com Thangavelu et al. (2004), o grau de inibição in vitro está diretamente correlacionado com a concentração de extratos em meio de BDA.

\section{CONCLUSÃO}

O controle total ou parcial observado com o uso dos extratos provenientes do bioma Caatinga, sobre o crescimento micelial de Colletotrichum musae demonstrou a existência de compostos com atividade fungitóxica. Com exceção do alecrim-do-campo que mostrou elevada eficiência, inibindo totalmente o crescimento micelial do Colletotrichum musae em todas as concentrações testadas, a eficiência na redução do crescimento micelial deste patógeno foi diretamente proporcional ao aumento das concentrações de extratos, sendo desta forma a concentração de $100 \%$ a de maior potencial de controle sobre o fungo, nas condições analisadas.

\section{REFERÊNCIAS}

[1] ALVES, P.M., QUEIRÓZ, L.M.G., PEREIRA, J.V., PEREIRA, M.S.V. Atividade antimicrobiana, antiaderente, antifúngica in vitro de plantas medicinais brasileiras sobre microorganismos do biofilme dental e cepas do gênero Cândida. Ver. Soc. Bras. Med. Trop, v.42, n. 2, p. 222-224. 2009.

[2] BARROS, P. N.; MONTEIRO, J. H. A.; COSTA, D. L.; SANTANA, A. E. G.; LIMA, G. S. A.; LEAL JUNIOR, G. A. Efeito de Extratos Vegetais, de Plantas da Caatinga, no Controle de Fitopatógenos. In: 45o Congresso Brasileiro de Fitopatologia, 2012, Manaus. Tropical Plant Pathology 38 (Suplemento). Viçosa-MG: Tec Art Editora Ltda, 2012. v. 38. p. 168-168. 
[3] CELOTO, M. I. B. Atividade antifúngica de extratos de melão-de-São-Caetano (Momordica charantia L.) sobre Colletotrichum musae (Berk e Curtis) Arx..2005. 74 f. Dissertação (Mestrado em Agronomia) - Faculdade de Engenharia de Ilha Solteira. Universidade Estadual Paulista, 2005.

[4] CORDEIRO, Z. J. M.; MATOS, A. P.; KIMATI, H. Doenças da bananeira. In: KIMATI, H.; AMORIM, L.; BERGAMIN FILHO, A.; CAMARGO, L. E. A. REZENDE, J. A. M. (Ed.). Manual de fitopatologia: doenças das plantas cultivadas. 4 ed. São Paulo: Agronômica Ceres, 2005. p.99-117.

[5] COSTA, E. M.M. de B. et al. In vitro antimicrobial activity of plant extracts of semi-arid region of Paraíba, PB, Brazil. Rev Odonto Cienc, v. 28, n. 4, p.101-104. 2013.

[6] IBGE - Instituto Brasileiro de Geografia e Estatística. Levant. Sistem. Prod. Agríc. Rio de Janeiro v.26 n.1 p.180 janeiro. 2013.

[7] LIMA, J. S.; PEREZ J. 0.; BARROS, P. N.; AZEVEDO, L. C.; MENDES, R. B.; PESSOA, R. A. Ação fungitóxica de extratos vegetais de plantas da caatinga sobre o crescimento micelial de Lasiodiplodia theobromae (Pat.) Griffon\& Maubl. em Vitis vinifera L. In: CONGRESSO NORTE-NORDESTE DE PESQUISA E INOVAÇÃO, 5, 2010, Maceió. Anais ... Maceió: CONNEPI, 2010. p. 23-26.

[8] PINHEIRO, A. A. F. Estudos de Inibição E Modelagem por Homologia da Enzima Beta (1,3)-D-Glicano Sintase de Moniliophthora Perniciosa. 2011.108f. Tese (Mestrado em Biotecnologia)- Universidade Estadual de Feira de Santana, Feira de Santana, BA, 2011.

[9] PINHO, L.; SOUZA, P. N. S.; SOBRINHO, E. M.; Almeida, A. C.; Martins, E. R. Atividade antimicrobiana de extratos hidroalcoolicos das folhas de alecrim- pimenta, aroeira, barbatimão, erva baleeira e do farelo da casca de pequi. Cienc. Rural, v. 42, n. 2, p. 326-331, 2012.

[10] SARAIVA, A. M. et al. Avaliação da Atividade Antimicrobiana e Perfil Fitoquímico de Caesalpinia Pyramidalis TULL. (FABACEAE). ISSN 1983-4209, v. 7, n. 2, p. 52-60. 2012.

[11] VENTUOSO, L. dos R. Extratos vegetais no controle de fungos fitopatogênicos à soja. 2009. 99f. Dissertação (Mestrado)- Universidade Federal da Grande Dourados, Mato Grosso do Sul. 2009. 


\title{
Capitulo 10
}

\section{Otimização do teor de lignina de resíduos de baru para a produção de biocarvão}

\author{
Yara Karla de Salles Nemet \\ Magale Karine Diel Rambo \\ Fábio Eduardo Nemet \\ Érica Priulli \\ Polyana Morais de Melo \\ Patricia Oliveira Vellano
}

Resumo: Analistas afirmam que a produção agrícola brasileira crescerá nesta década mais rápido do que em qualquer outra nação no mundo ( $40 \%$ até 2019), fato que gerará grande quantidade de resíduos de biomassa. Essa enorme quantidade de resíduos torna o biocarvão uma solução óbvia para um problema urgente: um modo rápido, barato e oportuno para estocar carbono e melhorar a qualidade do solo. 0 objetivo deste trabalho foi investigar o uso de biomassa de baru (mesocarpo e endocarpo) e quantificar o teor de lignina solúvel em ácido (ASL) e insolúvel (KL) para produzir bioprodutos otimizados através do conceito de biorrefinaria. Assim, RSM e DoE foram utilizados para melhorar o desempenho ou os experimentos. Para a otimização da lignina foram realizadas hidrólise ácida do mesocarpo e endocarpo de baru com três variáveis independentes; a primeira hidrolise foi realizada em banho-maria em diferentes intervalos de tempo $\left(\mathbf{X}_{1}\right)$ e temperatura $\left(\mathbf{X}_{3}\right)$, a segunda hidrólise foi realizada em autoclave a $120^{\circ} \mathrm{C}$ por diferentes intervalos de tempo $\left(\mathbf{X}_{2}\right)$. Os resultados estatísticos das análises realizadas mostraram características intrínsecas de lignina nos dois materiais produzidos (mesocarpo e endocarpo) o que comprova a eficiência da hidrólise ácida realizada ao obter lignina de baru. 0 RSM foi empregado para identificar os efeitos do tempo de hidrólise primário, secundário e a temperatura na hidrólise primária para a produção de lignina de Klason (KL) e lignina solúvel em ácido (ASL). 0 uso de RSM para otimizar procedimentos analíticos foi muito útil por causa de suas vantagens para a variáveis do processo, onde uma otimização de tempo e temperatura, como a geração de grandes quantidades de informações a partir de um pequeno número de experimentos e a possibilidade de avaliar o efeito de interação entre variáveis na resposta. Uma das modificações aplicadas aos métodos NREL foi muito útil para a biomassa em questão, alterando o tempo de hidrólise primário e secundário e temperatura primária para melhorar a recuperação do teor de lignina. 0 trabalho fornece o estudo das melhores condições para maior isolamento e conversão de lignina para produtos químicos de interesse industrial em biorrefinarias.

Palavras-Chave: Biomassa, Superfície de resposta, Conteúdo de lignina. 


\section{INTRODUÇÃO}

A produção agrícola brasileira vem crescendo a cada dia, diante disto teremos cada vez mais resíduos com potencial renovável. Entre os diferentes métodos de utilização de biomassa, este estudo concentra-se no biocarvão. Essa grande quantidade de biomassa torna o biocarvão uma solução óbvia para um problema urgente: um modo rápido, barato e oportuno para estocar carbono e aplicabilidade na melhoraria e qualidade do solo. 0 biocarvão é definido como a biomassa carbonizada sob atmosfera pobre em oxigênio cuja finalidade é o uso agrícola, visando à captura de carbono no solo e a melhoria de suas propriedades físico-químicas (ZUBIOLO et al., 2015).

Basicamente qualquer fonte de biomassa se presta à produção de biocarvão, porém devidas às diferenças existentes na composição química (teores de lignina, extrativos, celuloses e hemiceluloses) e na morfologia desses materiais, assim como nas condições de hidrólise e pirólise, o produto obtido apresenta características físicas e químicas particulares (RAMBO et al, 2015a).

O procedimento padrão NREL (2011a) recomenda o uso da hidrólise ácida para composição de biomassa lignocelulósica tem duas etapas: hidrólise primária em ácido sulfúrico a $72 \%$ a $30^{\circ} \mathrm{C}$ por $1 \mathrm{~h}$ seguida por hidrólise secundária da suspensão em $4 \%$ em peso de ácido autoclavadas a $121^{\circ} \mathrm{C}$ por $1 \mathrm{~h}$.

Para a otimização da lignina foram realizadas hidrólise ácida do mesocarpo e endocarpo de baru com três variáveis independentes; a primeira hidrolise foi realizada em banho-maria em diferentes intervalos de tempo $\left(\mathbf{X}_{1}\right)$ e temperatura $\left(\mathbf{X}_{3}\right)$, a segunda hidrólise foi realizada em autoclave a $120^{\circ} \mathrm{C}$ por diferentes intervalos de tempo $\left(\mathbf{X}_{2}\right)$.

O objetivo deste trabalho foi investigar o uso de biomassa de baru (mesocarpo e endocarpo) e quantificar o teor de lignina solúvel em ácido (ASL) e insolúvel (KL) em resíduos do fruto de baru (mesocarpo e endocarpo) para produzir bioprodutos otimizados através do conceito de biorrefinaria. Assim, RSM e DoE foram utilizados para melhorar o desempenho ou os experimentos.

\section{FUNDAMENTAÇÃO TEÓRICA}

O aproveitamento total do fruto é fundamental para a sustentabilidade da cadeia produtiva do mesmo. 0 baru (Dipteryx alata Vogel, Fabaceae) é considerado uma amêndoa que tem uma casca forte e dentro dela uma semente. Seus frutos têm polpa e amêndoas usadas para consumo humano, mas a semente é a parte mais comestível do baru, assim o mesocarpo e mesocarpo torna-se resíduos (FETTER et al., 2018; RESENDE et al., 2018; PINELLI et al., 2015).

As biomassas residuais lignocelulósica, são fonte de energia renováveis paraconversão em líquidos, gases, combustíveis, produtos químicos e biomateriais (RAMBO et al., 2015b). A biomassa residual do baru, destaca-se por suas propriedades físicas e químicas favoráveis, com característica que diferencia o carvão do baru daquele obtido por madeira é o teor de cinzas, que se apresenta elevado (VALE \& OLSEN, 2013).

Neste contexto, os materiais lignocelulósicos, como resíduos agrícolas, resíduos florestais e culturas energéticas, são tipicamente compostos de celulose, hemiceluloses e lignina como constituintes primários. Entre os compostos derivados da biomassa, a lignina é um componente subutilizado com potencial de conversão para produtos industrialmente necessários em biorrefinaria, como o biocarvão (INKROD et al., 2018).

O biocarvão é o produto sólido obtido a partir da pirólise, com valor agregado, que pode ser usado para muitos propósitos. É altamente carbonoso e, portanto, contém um alto conteúdo energético, comparável a carvões de alta classificação 0 biocarvão também possui uma grande superfície microscópica devido aos micrósporos desenvolvidos durante a pirólise, e pode ser usado para a filtração e adsorção de poluentes. Tal característica do biocarvão pode ser ainda melhorada pela ativação física ou química, da qual o produto final é referido como carbono ativado (LEE et al., 2013).

A hidrólise ácida é a tecnologia mais promissora utilizada para converter esses polímeros em produtos de interesse. Consiste em catalisar a clivagem da ligação química via reação de substituição nucleofílica em meio aquoso. Os hidratos de carbono poliméricos são hidrolisados nas suas formas monoméricas durante a hidrólise, estas formas são solúveis na hidrólise líquida. Este procedimento tem dois passos principais: 1) hidrólise de ácido sulfúrico forte a temperatura ambiente com a finalidade de separar completamente os polissacarídeos da lignina, em seguida 2) hidrólise secundária com a temperatura mais elevada após diluição da suspensão de hidrólise primária, com a finalidade de despolimerizar os oligômeros de açúcar para monômeros (BHAGIA et al., 2016) . 
No estágio de hidrólise primária sugere-se que a lignina e os polissacarídeos são completamente separados (BHAGIA et al., 2016). A lignina extraída é dividida em materiais insolúvel e solúveis em ácido. 0 material insolúvel em ácido também pode incluir proteína cinzenta, que deve ser considerada durante a análise gravimétrica. Por outro lado, a lignina solúvel é hidrolisada e deve ser considerada no ultravioletavisível (UV / Viv) espectrofotometria (RAMBO et al., 2015b).

No entanto, assim, o procedimento de hidrólise é uma convenção geral para a biomassa lignocelulósica e não para uma matéria-prima específica. Isso pode afetar o desempenho de procedimentos de hidrólise. Portanto, utilizamos o design de experimentos (DoE) e RSM para otimizar as melhores condições (BOX et al., 1978; BARROS et al., 2002) e maximizar o rendimento dos processos de hidrólise das biomassas brasileiras, como os resíduos de baru. Ambos os métodos estão entre as mais relevantes técnicas multivariadas utilizadas na otimização analítica (BEZERRA et al., 2008), podem ser bem aplicados quando uma resposta de interesse é influenciada por diversas variáveis, como o desta pesquisa.

\section{METODOLOGIA}

\subsection{MATÉRIA-PRIMA}

Os frutos de Baru (Dipteryx alata Vog.) utilizados neste trabalho foram coletados em Porangatu, estado de Goiás, Brasil, em outubro de 2017, onde foram armazenados em embalagem de sacos plásticos. As amêndoas do baru foram retiradas manualmente com um auxílio de uma faca. Os frutos foram secos em estufa com circulação de ar (SolidSteel SSD 110L) a $105{ }^{\circ} \mathrm{C}$ por $12 \mathrm{~h}$, e separados manualmente o mesocarpo e o endocarpo lenhoso. Após a separação ambas amostras, foram trituradas em moinho (moinho de tipo willye, modelo star FT 50, marca Fortenox) em sequência foram peneiradas até o tamanho de partículas de 48 mesh e armazenadas em frascos de vidros herméticos.

\subsection{HIDRÓLISE ÁCIDA}

A amostra bruta (1g) foi submetida a um processo de hidrólise ácida usando o procedimento de acordo com a metodologia descrita pelo Laboratório Nacional de Energia Renovável (NREL, 2011a). No primeiro passo, a amostra e o ácido sulfúrico a $72 \%(8 \mathrm{~mL})$ foram transferidos para um banho-maria, mantidos a temperatura e tempo de acordo com a tabela 1 ( $\mathbf{X}_{\mathbf{1}}$ e $\mathbf{X}_{\mathbf{3}}$ ). Na segunda etapa, foram adicionados água destilada (284 mL) e a amostra foi transferida para autoclave (autoclave vertical, Phoenix) a $120^{\circ} \mathrm{C}$ e o tempo de acordo com a variável $\left(\mathbf{X}_{2}\right)$. Os tubos de pressão foram filtrados em cadinhos de porosidade média (10 a $15 \mu \mathrm{m}$ ) utilizando uma bomba de vácuo compressor (LT 65, Limatec, acoplado). 0 resíduo insolúvel em ácido (RA) retidos nos cadinhos continha a lignina insolúvel, definido como lignina de Klason (KL) do qual foi lavada com água destilada até a completa remoção do ácido, e logo depois levados a um forno a $105^{\circ} \mathrm{C}$ por $12 \mathrm{~h}$.

\subsection{QUANTIFICAÇÃO TEOR DE LIGNINA}

A lignina de Klason (KL) e a lignina solúvel em ácido (ASL) foram determinadas de acordo com Laboratório Nacional de Energia Renovável (NREL, 2011a). Para ASL determinou em espectrofotômetro UV-Vis (HACH/Germany, DR5000) com comprimento de onda de $294 \mathrm{~nm}$ com de H2SO4 a 4\% (m/v) solução do branco. 0 total de lignina (TL) é a soma da KL+ ASL.

\subsection{ANÁLISE ESTATÍSTICA E DESIGN EXPERIMENTAL}

Os experimentos foram realizados de acordo com os métodos de metodologia de superfície de resposta (RSM) e do delineamento composto central (DCC) com adição de ponto central, com auxílio do programa Protimiza Experimental Design (http://experimental- design.protimiza.com.br/), com três repetições em níveis centrais para encontrar o erro experimental estimado. A metodologia consistiu em um erro fatorial ou experimental completo 
A metodologia consistiu em um planejamento fatorial de pontos adicionais a uma distância $\alpha$ de seu centro.

Tabela 1: Fatores e níveis de projeto do DoE.

\begin{tabular}{|c|c|c|c|c|}
\hline \multirow{2}{*}{ Variáveis } & \multirow{2}{*}{ Código } & \multicolumn{3}{|c|}{ Níveis } \\
\hline & & -1 & 0 & +1 \\
\hline 1을 Temo de hidrólise(horas) & $\mathbf{X}_{1}$ & 1 & 2 & 3 \\
\hline $2^{\mathrm{a}}$ Tempo de hidrolise (horas) & $\mathbf{X}_{2}$ & 1 & 1,5 & 2,0 \\
\hline $1^{\mathrm{O}}$ Temperatura de hidrólise $(\stackrel{\circ}{ } \mathrm{C})$ & $\mathbf{X}_{3}$ & 30 & 60 & 90 \\
\hline
\end{tabular}

Fonte: Própria

\subsection{CARACTERIZAÇÃO DA LIGNINA DE KLASON (KL) ATRAVÉS DA ESPECTROSCOPIA POR INFRAVERMELHO}

Para a análise estrutural do material sólido após a hidrólise ácida, foram realizados através da espectroscopia FT-NIR. Os espectros das amostras do resíduo ácido do baru (mesocarpo e endocarpo) foram obtidos em duplicata e o espectro médio foi utilizado. Os espectros na região do infravermelho próximo foram obtidos em um espectrômetro Agilent Technologies (CARY 630 FTIR) de feixe único, no modo de reflectância difusa, na faixa de 650 a $4000 \mathrm{~cm}^{-1}$ (variação total) com incrementos de 0,5 nm e foram calculados a média de 32 varreduras. Os espectros de infravermelho por reflectância difusa serão transformados para absorbância (A) usando $A=\log 10(1 / \mathrm{R})$.

\section{RESULTADOS E DISCUSSÕES}

Os resultados estatísticos das análises realizadas mostraram características intrínsecas de lignina nos dois materiais produzidos (mesocarpo e endocarpo) o que comprova a eficiência da hidrólise ácida realizada ao obter lignina de baru.

As Tabelas 2 e 3 mostram os resultados de KL e ASL do endocarpo e mesocarpo, respectivamente, com base no CCD. Os pontos centrais (em ambas as tabelas) apresentaram pequena variação (desvio padrão inferior a $0,50 \%$ ) e boa repetitividade do processo.

Tabela 2: Fatores e níveis de projeto do DoE do teor de KL ( $\left.\mathrm{Y}_{1}\right)$ e ASL ( $\left.\mathrm{Y}_{2}\right)$ endocarpo do baru.

\begin{tabular}{|c|c|c|c|c|c|}
\hline Variáveis & -1 & 0 & 1 & & \\
\hline$\left(\mathrm{X}_{1}\right) 1^{\circ}$ Tempo de hidrólise(horas) & 1 & 2 & 3 & & \\
\hline$\left(\mathrm{X}_{2}\right) 2^{\circ}$ Tempo de hidrolise (horas) & 1 & 1,5 & 2 & & \\
\hline$\left(\mathrm{X}_{3}\right) 1^{\circ}$ Temperatura de hidrólise $\left({ }^{\circ} \mathrm{C}\right)$ & 30 & 60 & 90 & & \\
\hline Experiments & $\mathrm{X}_{1}$ & $\mathrm{X}_{2}$ & $\mathrm{X}_{3}$ & $\mathrm{Y}_{1}(\mathrm{KL})$ & $\mathrm{Y}_{2}$ (ASL \\
\hline 1 & -1 & -1 & -1 & 37,03 & 1,45 \\
\hline 2 & 1 & -1 & -1 & 38,15 & 1,97 \\
\hline 3 & -1 & 1 & -1 & 29,47 & 5,02 \\
\hline 4 & 1 & 1 & -1 & 30,11 & 2,07 \\
\hline 5 & -1 & -1 & 1 & 60,50 & 0,26 \\
\hline 6 & 1 & -1 & 1 & 57,24 & 0,16 \\
\hline 7 & -1 & 1 & 1 & 52,87 & 3,21 \\
\hline 8 & 1 & 1 & 1 & 57,56 & 0,26 \\
\hline 9 & 0 & 0 & 0 & 61,16 & 1,34 \\
\hline 10 & 0 & 0 & 0 & 52,31 & 1,01 \\
\hline 11 & 0 & 0 & 0 & 63,72 & 1,09 \\
\hline
\end{tabular}

*DoE: Designer of Experimentos (Designer de Experimentos)

Fonte: Própria 
Tabela 3: Fatores e níveis de projeto do DoE do teor de KL (Y1) e ASL (Y2) mesocarpo do baru.

\begin{tabular}{|c|c|c|c|c|c|}
\hline Variáveis & -1 & 0 & 1 & & \\
\hline$\left(\mathrm{X}_{1}\right) 1^{\circ}$ Tempo de hidrólise(horas) & 1 & 2 & 3 & & \\
\hline$\left(\mathrm{X}_{2}\right) 2^{\circ}$ Tempo de hidrolise (horas) & 1 & 1,5 & 2 & & \\
\hline$\left(\mathrm{X}_{3}\right) 1^{\mathrm{a}}$ Temperatura de hidrólise $\left({ }^{\circ} \mathrm{C}\right)$ & 30 & 60 & 90 & & \\
\hline Experimentos & $\mathrm{X}_{1}$ & $\mathrm{X}_{2}$ & $\mathrm{X}_{3}$ & $\mathrm{Y}_{1}(\mathrm{KL})$ & $\mathrm{Y}_{2}$ (ASL) \\
\hline 1 & -1 & -1 & -1 & 40,44 & 1,12 \\
\hline 2 & 1 & -1 & -1 & 44,07 & 1,11 \\
\hline 3 & -1 & 1 & -1 & 23,47 & 4,38 \\
\hline 4 & 1 & 1 & -1 & 31,72 & 1,36 \\
\hline 5 & -1 & -1 & 1 & 54,74 & 0,20 \\
\hline 6 & 1 & -1 & 1 & 54,34 & 0,17 \\
\hline 7 & -1 & 1 & 1 & 44,90 & 3,02 \\
\hline 8 & 1 & 1 & 1 & 51,03 & 0,14 \\
\hline 9 & 0 & 0 & 0 & 56,63 & 0,63 \\
\hline 10 & 0 & 0 & 0 & 54,98 & 0,62 \\
\hline 11 & 0 & 0 & 0 & 52,13 & 0,44 \\
\hline
\end{tabular}

*DoE: Designer of Experimentos (Designer de Experimentos)

Fonte: Própria

A inspeção visual dos gráficos residuais levou a informações valiosas sobre a adequação do modelo. A Figura 1 mostra o gráfico dos valores previstos em comparação com os resultados experimentais correspondentes.

Figura 1: Gráficos obtidos para a biomassa de mesocarpo no KL(A) e ASL (B). Gráficos para a biomassa de endocarpo no KL (C) e ASL (D) onde o eixo X é o valor experimentais e no eixo Y os valores previstos.

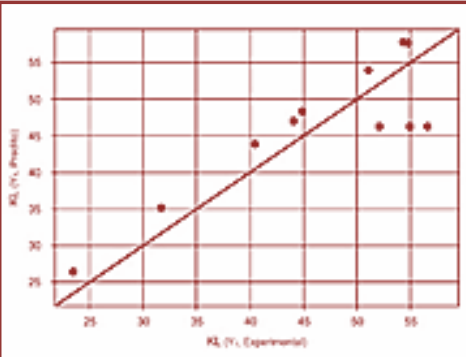

(A)

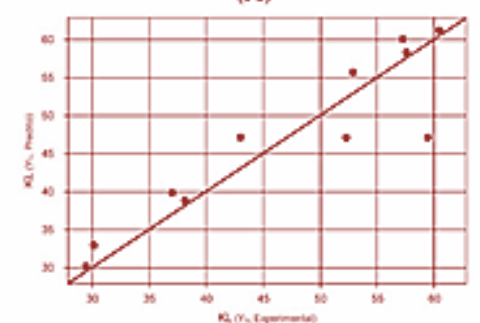

(C)

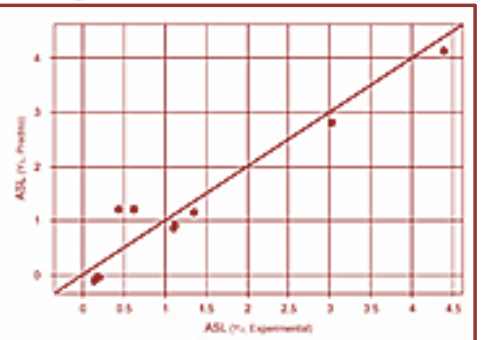

(B)

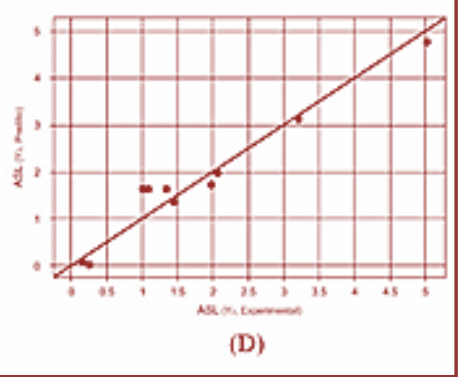

(D)

Fonte: Própria

Os pontos foram distribuídos aleatoriamente próximo da linha e apresentaram excelente consistência, o modelo não apresentou escassez significativa de ajuste. Os valores de predição e erro experimental foram inferiores a 0,40\% nos modelos da Figura 2(A e C) para ASL, e que o modelo matemático se ajustou bem ao gráfico do modelo de resíduos sugeriu distribuição normal (BRUNS et al., 2006). Já para os modelos de regressão das Figuras 2(B e D) para KL, o erro experimental foram altos $(<74 \%)$. 
As Figuras 2 (A) e (B) mostram os efeitos dos tempos de hidrólise $\left(1^{\mathrm{a}}\right)$ e $\left(2^{\mathrm{a}}\right)$ no rendimento de KL e ASL no mesocarpo, enquanto as Figuras 2 (C) e (D) mostram os efeitos dos tempos de hidrólise no endocarpo. Para o rendimento de KL e ASL, observamos uma produção maximizada de aproximadamente 52,3\% e 3,5\% fixando a hidrólise primária à 1h (Figuras 2 (A) e (B)) e para tempos de hidrólise secundária 30 e 60 min em KL e ASL, respectivamente.

Figura 2: (A) Gráficos da superfície de resposta para a biomassa de mesocarpo no KL e (B) para ASL (B).

(C) Gráficos da superfície de resposta para a biomassa de endocarpo no KL e (D) ASL (D).

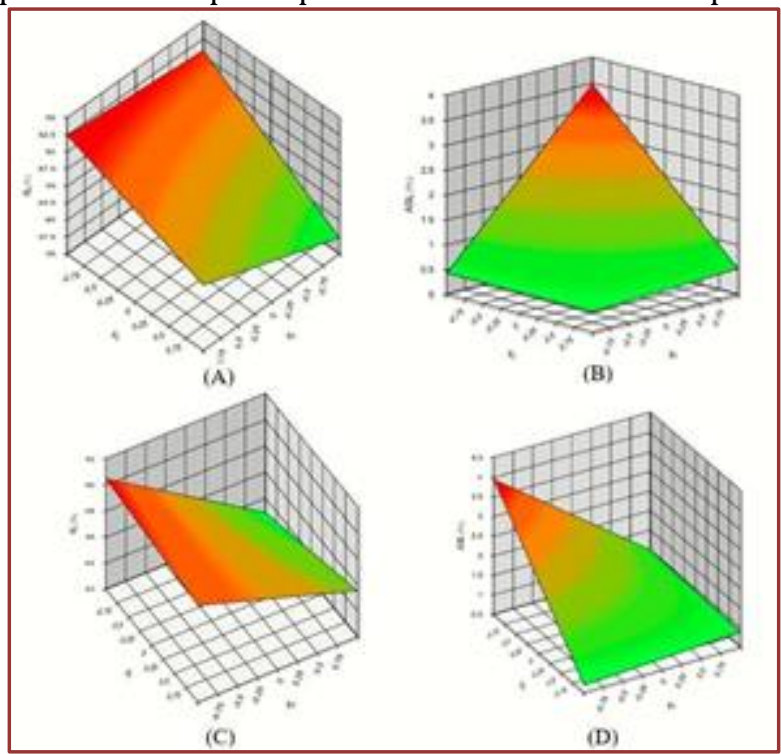

Fonte: Própria

As Figuras 2 (C) e (D) têm efeitos opostos sobre KL e ASL, enquanto o tempo mínimo de KL na hidrólise primária, associado ao tempo máximo de hidrólise secundária, favorece maior produção de ASL. 0 tempo mínimo na hidrólise primária associada o tempo mínimo em hidrólise secundária fornece níveis máximos de lignina de Klason (>50,0\%).

A análise dos números, mais uma vez, enfatizou o fato de que as metodologias NREL precisam ser adaptadas para cada tipo de biomassa. Portanto, a hidrólise secundária é pelo menos 30 min menos longa que o tempo de reação padrão, o que levou a melhores resultados meníngeos em ambos os resíduos do baru. 0 aumento de 1 hora no procedimento padrão levou ao rendimento máximo do processo no endocarpo, por exemplo.

As equações usando os coeficientes de regressão e os resultados estatísticos de todos os modelos do endocarpo e mesocarpo são descritos na Tabela 4.

A interação entre variáveis foi significativa em todos os modelos envolvendo o ASL em ambos os resíduos do baru. 0 modelo não foi satisfatório para o KL no mesocarpo e endocarpo. Ou seja, os Fcalculados foram maiores que os tabulados de F somente para o ASL e evidenciaram a significância estatística da regressão. Indica-se que os modelos matemáticos se ajustam bem aos dados experimentais (BARROS et al., 2002).

Tabela 4: Equações de regressão e parâmetros estatísticos dos modelos ao nível de significância de 5\% (p $<0,05)$.

\begin{tabular}{|l|c|c|}
\multicolumn{1}{c|}{ Equações } & $F_{\text {cal. }}$ & $R^{2}$ \\
\hline MesoKL: $46,22+2,20 x_{1}-5,31 x_{2}+8,16 x_{3}+1,39 x_{1} x_{2}-0,77 x_{1} x_{3}+2,02 x_{2} x_{3}$ & 1,9 & 0,74 \\
\hline MesoASL $=1,20-0,74 x_{1}+0,79 x_{2}-0,56 x_{3}-0,73 x_{1} x_{2}+0,01 x_{1} x_{3}-0,09 x_{2} x_{3}$ & 6,4 & 0,90 \\
\hline EndoKL= 47,22+0,40 $x_{1}-2,86 x_{2}+11,68 x_{3}+0,93 x_{1} x_{2}-0,04 x_{1} x_{3}+1,04 x_{2} x_{3}$ & 2,8 & 0,81 \\
\hline EndoASL $=1,62-0,68 x_{1}+0,84 x_{2}-0,83 x_{3}-0,79 x_{1} x_{2}-0,08 x_{1} x_{3}-0,08 x_{2} x_{3}$ & 12,8 & 0,95 \\
\hline
\end{tabular}

Legenda: MesoKL: rendimento do KL no mesocarpo; MesoASL: rendimento de ASL no mesocarpo; EndoKL: rendimento do KL no endocarpo; EndoASL: rendimento de ASL no endocarpo. 
0 modelo que se ajusta às respostas observadas foi obtido através da determinação de $\mathrm{R}^{2}$, indicando que mais de $80 \%$ da variação total foi explicada pelos modelos de regressão, exceto os modelos encontrados para o KL do mesocarpo.

Sugere que os modelos para o ASL são adequados para avaliar o comportamento da temperatura e tempo de reação da hidrólise frente a obtenção do teor de lignina em resíduos do baru.

\subsection{CARACTERIZAÇÃo QUÍMICA DA LIGNINA DE KLASON (KL) RECUPERADA APÓS HIDRóLISE ÁCIDA}

Na análise química após as hidrólises, espectros da região do infravermelho foram obtidos. As figuras 3(a) e (b) revelaram que os grupos funcionais eram semelhantes. Bandas características na aproximadamente na região de $830 \mathrm{~cm}^{-1}$ atribuídas a vibração $\mathrm{C}$-H fora do plano, provavelmente de estruturas de $\mathrm{R} 2 \mathrm{C}=\mathrm{CHR}$ da molécula de lignina. Observa-se esse comportamento no endocarpo para ambas os experimentos e essa banda é mais proeminente em condições de hidrólise secundária alta, enquanto que nos espectros para o experimento 3, a intensidade é reduzida, o que significa que parte da lignina foi eficientemente recuperada em condições de hidrólise primária e secundária intermediários do padrão, o mesmo ocorreu para o mesocarpo.

Figura 3: Espectros de infravermelho dos resíduos sólidos após hidrólise ácida do endocarpo (a) e mesocarpo do baru, em quatro diferentes condições de hidrólise ácida.

(a)

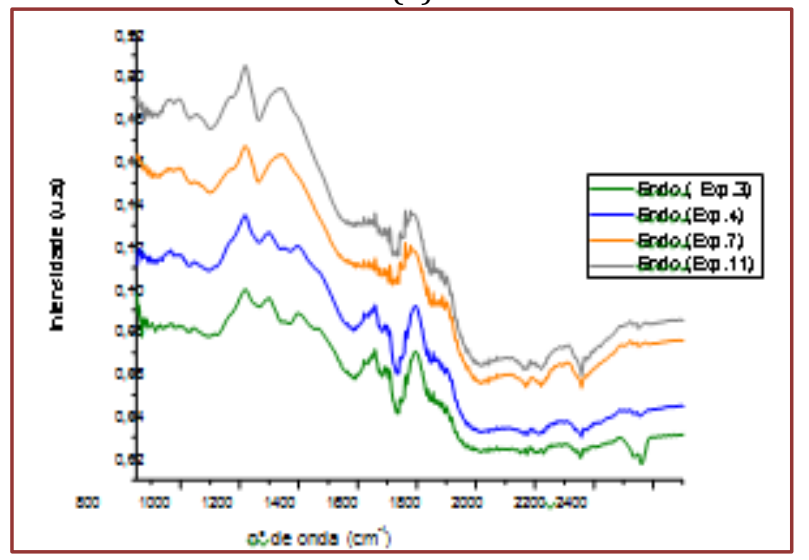

(b)

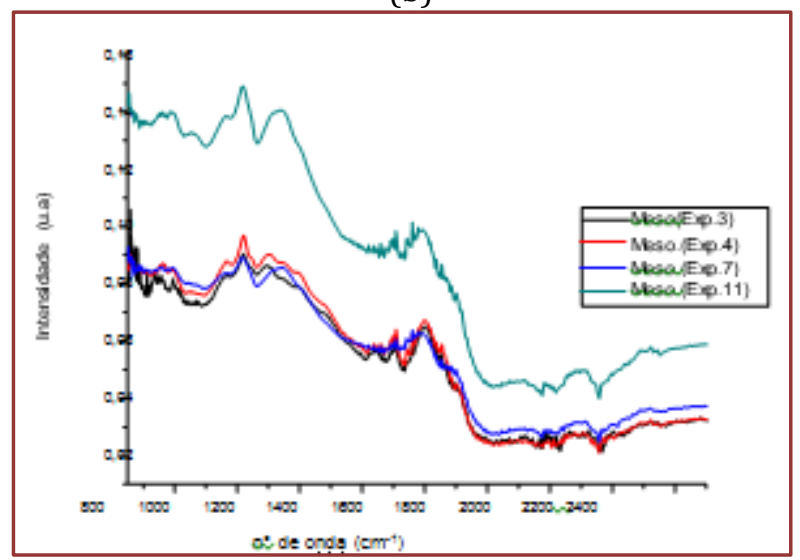

Fonte: Própria

Composto aromático H-C na deformação plana na banda de $1031-1037 \mathrm{~cm}^{-1}$ podem ser observados em todas as amostras de lignina, endocarpo (a) e mesocarpo (b) com diferentes intensidades. No mesocarpo esse comportamento para ambas os experimentos são observados, mas somente par ao experimento 11 a intensidade foi maior. Foi observado também para ambas as biomassas, presença de grupo $0=$ alongamento do grupo carboxila que mostrou picos em $1693-1713 \mathrm{~cm}^{-1}$.

\section{CONCLUSÕES}

As biomassas brasileiras, como os resíduos de baru, são potenciais materia -prima para a produção de combustíveis líquidos e sólidos. A composição química é favorável sob altos níveis de carboidratos e lignina.

O RSM foi empregado para identificar os efeitos do tempo de hidrólise primário, secundário e a temperatura na hidrólise primária para a produção de lignina de Klason (KL) e lignina solúvel em ácido (ASL). O uso de RSM para otimizar procedimentos analíticos foi muito útil por causa de suas vantagens para a variáveis do processo, onde uma otimização de tempo e temperatura, como a geração de grandes quantidades de informações a partir de um pequeno número de experimentos e a possibilidade de avaliar o efeito de interação entre variáveis na resposta. 
As condições experimentais (1h e $30 \mathrm{~min}$ ) aplicadas ao endocarpo e ao mesocarpo proporcionaram os melhores teores de KL. Portanto, encontramos baixos custos energéticos em ambas as biomassas em um processo de biorrefinarias utilizando tempo otimizado entre $1 \mathrm{~h}$ e $2 \mathrm{~h}$. A eficiência no isolamento de lignina dependeu fortemente dos tipos de biomassa (endocarpo e mesocarpo), como mostrado nas características do KL recuperado. Em relação ao desempenho dos produtos de interesse quando se trata de custo, o melhor processo diz a respeito ao teor de ASL.

A qualidade dos modelos de encaixe e sua precisão para predizer os dados experimentais obtidos foram satisfatórios, exceto para o teor de KL no mesocarpo. Para os demais, o alto valor do coeficiente de determinação ajustado nos modelos (maior que $\mathrm{R}^{2}=0,80$ ) e a diferença não significativa entre os valores preditos e experimentais demonstraram a validade dos modelos de otimização aqui propostos em termos estatísticos.

Uma das modificações aplicadas aos métodos NREL foi muito útil para a biomassa em questão, alterando o tempo de hidrólise primário e secundário e temperatura primária para melhorar a recuperação do teor de lignina. 0 trabalho fornece o estudo das melhores condições para maior isolamento e conversão de lignina para produtos químicos de interesse industrial em biorrefinarias.

\section{REFERÊNCIAS}

[1] BARROS, B. N.; SCARMINIO, I. S.; BRUNS, R. E. Como fazer experimentos: pesquisa e desenvolvimento na ciência e na indústria.2.ed.Campinas: Unicamp, 2002.

[2] BEZERRA, M. A. et al. Response surface methodology (RSM) as a tool for optimization in analytical chemistry. Talanta, v.76, p. 965-977, 2008.

[3] BHAGIA, S.; Nunez, A.; Wyman, C. E.; Kumar, R. Robustez of two-step acid hydrolysis procedure for composition analysis of poplar. Bioresource Technology, v. 216, p. 1077-1082, 2016.

[4] BOX, G.E.P.; HUNTER, H.G.; HUNTER, J.S. Statistics for experiments.2th ed. New York: John Wiley Co., 1978.

[5] BRUNS, ROE.; SCARMINIO, I. S.; NETO, B.B. Statistical Design: chemometrics. 2nd ed. Amsterdam: Elsevier, 2006.

[6] FETTER, D. L.; CRUZ, P.N.; HAMASAKI, F.; CRAZE, M. L. Extraction of bare (Dietary balata Vogel) seed oil using compressed solvents technology. The Journal of Supercritical Fluids, v. 137, p. 23-33, 2018.

[7] INK ROD, C.; RAITA, M.; CHAMPED, V.; LAOSIRIPOJANA, N. Characteristics of Lignin Extracted from Different Lignocellulosic Materials via Organosolv Fractionation. BioEnergy Research, v. 11, p. 277-290,2018.

[8] LEE, Y; Parque, J; Ryu, C; Gang, K.S.; YANG, W.; PARQUE, Y-K.; JUNG, J.; HYUN, S. Comparison of biochar properties from biomass residues produced by slow pyrolysis at $500^{\circ} \mathrm{C}$. Bioresource Technology, v.148, p.196-201,2013.

[9] NREL/ NREL/TOP-510-42618: Determination of structural carbohydrates and lignin in biomass. Biomass Analysis Technology Team Laboratory Analytical Procedure, National Renewable Energ Lab, 2011a.

[10] NREL/TP-510-42619: Determination of Extractives in Biomass. Biomass Analysis Technology Team Laboratory Analytical Procedure, National Renewable Energy Lab, 2011b.

[11] PINELI, L.; OLIVEIRA, G.; MENDONÇA, M; BORGO, L.; FREIRE, E.; CELESTINO, S;

[12] CHIARELLO, M., BOTELHO , R. Tracing chemical and sensory characteristics of baru oil during storage under nitrogen. LWT - Food Science and Technology, v. 62, p. 976- 982,2015.

[13] RAMBO, M. K. D.; ALEXANDRE, G. P.; 1, RAMBO, M. C. D.; ALVES, A. R.; GARCIA,

[14] W. T., BARUQUE, E. Characterization of biomasses from the north and northeast regions of Brazil for processes in biorefineries.Food Science and Technology, v.35, n.4,p.605-611, 2015a.

[15] RAMBO, M. K .D.; SCHMIDT, F. L.; FERREIRA; M.M.C. Analysis of the lignocellulosic componentes of biomass residues for biorefinery opportunities. Talanta, v. 144, p.696-703, 2015b.

[16] RESENDE, O.; OLIVEIRA, D. E. C., COSTA, L. M., JÚNIOR, W. N. F. Drying inetics of baru fruits (Dipteryx alata Vogel). Engenharia Agrícola, Jaboticabal, v.38, n.1, p.103-109, jan./feb., 2018.

[17] VALE, A. T.; OLSEN, L. B. Produção de carvão vegetal de casca de baru (Dipteryx alata) utilizando células de carbonização. Floresta, v. 43, n. 1, p. 117-124, 2013.

[18] ZUBIOLO, C; PEREIRA, L. L; FREITAS, L.S; RUZENE, D. S; SILVA, D. P. Desenvolvimento e produção de bio-óleo a partir de resíduos lignocelulósicos. VII SIMPROD - Simpósio de Engenharia de Produção de Sergipe, São Cristovão-SE, 2015. 


\section{Capítulo 11}

Potencial bioeconômico de Euterpe oleracea Mart:: Respostas térmicas do caule do açaizeiro testado por espectroscopia infravermelho

\section{Cezar Dias Cardoso Junior \\ Bruno Monteiro Balboni \\ Alessandra Silva Batista \\ Rafael de Aguiar Rodrigues \\ Diego Lima Aguiar \\ Lucieta Guerreiro Martorano}

Resumo: 0 poliestireno expandido (EPS) tem sido amplamente utilizado como isolante térmico, mas sua reduzida biodegradabilidade tem limitado busca-se por produtos de fonte natural que apresentem propriedades isolantes. 0 caule do açaizeiro possui características como biodegradabilidade e baixa densidade, podendo ser testado como alternativa para substituir o EPS. Neste trabalho o objetivo foi avaliar o potencial bioeconômico do interior do caule do açaizeiro como usos múltiplos comparando-o com o EPS e três espécies de madeiras amazônicas de diferentes densidades. Nos corpos de provas expostos ao sol foram realizados termogramas usando um termógrafo no infravermelho próximo. Os resultados demonstram que apesar de apresentar baixa densidade aparente, 0,28 g.cm-3, o caule do açaizeiro apresentou temperatura duas vezes superior ao EPS, bem como superior às outras espécies madeireiras de densidade até 3 vezes maior, não sendo apropriado, portanto, para isolamento térmico, sob condição de plena exposição aos raios solares.

Palavras-Chave: infravermelho próximo, sílica, estegmata, densidade. 


\section{INTRODUÇÃO}

O poliestireno expandido pertence ao grupo das resinas termoplásticas com origem no petróleo e tornouse um produto cada vez mais utilizado pelo mercado como isolante térmico, por se tratar de um material leve, com baixa condutividade térmica e de baixo custo (CALLES-ARRIAGA et al., 2016; CARVALHO e MOTTA, 2019). Entretanto, seu uso demanda atenção, podendo ser prejudicial à natureza por ser um material sintético e não biodegradável, levando em média 150 anos para se decompor. Seu descarte pode gerar danos ambientais, como impedir absorção de água pelo solo e, os fragmentos do isopor podem ser ingeridos por vidas marinhas como peixes e crustáceos, prejudicando o extrato digestivo deles (MENDES, 2002 e AMBIENTE BRASIL, 2011).

Da porção central do caule do açaizeiro pode-se obter um material com características passíveis de uso como estratégia de substituição de isolantes térmicos convencionais, por ser um resíduo biodegradável e possuir baixa densidade. 0 açaizeiro (Euterpe oleracea Mart.) é uma espécie de palmeira nativa da região Amazônica, gera o fruto muito apreciado "açaí" e outra forte de alimento que é o palmito, os quais possuem importância na alimentação e na economia das comunidades tradicionais (OLIVEIRA et al., 2002). E. oleracea nativo ocorre em áreas com alta oferta hídrica no solo, cresce na forma de touceira, onde o número excessivo de perfilhos (caules da touceira) podem resultar na redução do desenvolvimento da planta-mãe (NETO et al., 2012). A alternativa para aumento da produtividade de frutos consiste no desbaste seletivo, trato silvicultural em que se objetiva diminuir o número de perfilhos, de forma que cada touceira apresente, no máximo, cinco caules (OLIVEIRA et al., 2000).

Os caules resultantes do manejo do açaizeiro, apesar de apresentarem condições de uso em construções rústicas, geralmente se acumulam no chão das áreas de produção, mas poderiam ser destinados à manufatura de bioprodutos que agregassem valor e renda ao resíduo. Foi demonstrado o potencial de uso para a zona periférica do caule do açaizeiro, da mesma forma que as baixas propriedades mecânicas da porção central do caule (BALBONI et al., 2018). Devido à sua baixa densidade, uma possível aplicação desta porção central seria justamente o isolamento térmico. A espectroscopia no infravermelho próximo pode subsidiar análises quanto ao potencial deste material como isolante térmico por ser considerada um método eficiente, rápido, simples, não destrutivo e não invasivo (OLIVEIRA et al., 2015; SAMISTRARO, 2009).

Desta forma, no presente trabalho, o objetivo foi avaliar o potencial da porção central do caule do açaizeiro como isolante térmico, comparando-o com o isolante mais utilizado, o Poliestireno Expandido (EPS), e três espécies de madeira amazônicas de diferentes densidades.

\section{MATERIAIS E MÉTODOS}

Seis caules de açaizeiro (Euterpe oleracea Mart.) foram coletados na comunidade de São Brás. Distante 8 $\mathrm{km}$ da área urbana da cidade de Santarém-PA. Cada caule foi extraído do centro de seis diferentes touceiras, por serem caules de maior idade dentro dos indivíduos. Três espécies madeireiras da região Amazônica foram selecionadas para representar materiais ligno celulósicos de diferentes densidades. A madeira de Breu (Protium apiculatuum), Cedro (Cedrela fissilis) e Massaranduba (Manilkara huberi) são provenientes da Floresta Nacional do Tapajós e foram doadas pelo Laboratório de Tecnologia da Madeira da Universidade Federal do Oeste do Pará. Já o Poliestireno Expandido (EPS) foi adquirido no comércio no município de Santarém, Pará. Cada um dos cinco materiais, denominados tratamentos, foi representado por seis repetições.

Os corpos de prova foram confeccionados nas dimensões $25 \mathrm{~mm}$ x $50 \mathrm{~mm}$ x $150 \mathrm{~mm}$ (espessura x largura x comprimento) em serra circular de bancada. No caso do açaizeiro, cada indivíduo coletado gerou um corpo de prova, sendo que o desdobro ocorreu com o material ainda na umidade verde. Logo após o preparo, as amostras foram acondicionadas em sala de aclimatação com temperatura média de $20^{\circ} \mathrm{C}( \pm$ $2^{\circ} \mathrm{C}$ ) e umidade relativa do ar de $60 \%( \pm 5 \%)$ de umidade, visando atingir a umidade de equilíbrio de $12 \%$. Após atingirem massa constante, esta foi aferida em balança semi-analítica (precisão de 0,01 g) e o volume pelo método de deslocamento em água (VITAL, 1984), para posterior cálculo da densidade aparente a $12 \%$ de umidade (massa/volume). Na sequência, as amostras retornaram à sala de aclimatação para que sua umidade se mantivesse em $12 \%$ para as próximas etapas.

Uma bancada de madeira, distando $1 \mathrm{~m}$ do solo, foi utilizada como apoio para as amostras, deixando-as expostas ao sol em dia com total ausência de nuvens. Para evitar a influência do calor refletido pela bancada, esta era vazada e os corpos de prova foram apoiados em fios de nylon previamente tensionados. 
As amostras foram dispostas em linhas (blocos), de forma que cada bloco possuísse um representante de cada tratamento e as amostras distassem $50 \mathrm{~mm}$ uma da outra. Foram realizados diagnósticos termográficos no infravermelho próximo, usando câmera FLIR T658sc, com captura de imagens no período das 10h:00 min às 14h:00 min. As imagens termográficas (12 por bloco), necessariamente, continham um bloco completo, ou seja, um representante de cada tratamento. Posteriormente, as imagens foram tratadas por meio do software FLIR tools Versão 5.13 (18031.2002), sendo os pontos térmicos escolhidos por padrões de cores estratificados a partir da seleção da paleta RAIN.PAL, onde foram obtidos dados de temperatura média, mínima e máxima em três zonas da superfície exposta ao sol: centro, bordadura e caixa (Figura 1).

Amostras do centro do caule do açaizeiro foram colocadas em solução de água e glicerina na proporção 2:1 (24h) e posteriormente emblocadas em Polietilenoglicol1500 (GERLACH, 1984) para confecção de lâminas histológicas permanentes. Foram obtidos cortes longitudinais com micrótomo de deslize, em espessura de 15 - $20 \mu \mathrm{m}$, desidratados e corados com Safranina e Azul de astra (Safrablau) (KRAUS e ARDUIN, 1997). Imagens das lâminas histológicas foram tomadas através de microscopia óptica e de luz polarizada por meio do microscópio Leica DM750 P.

Os testes de Shapiro-Wilk e Bartlett $(\alpha=0,05)$ foram aplicados para verificar a normalidade do resíduo e homogeneidade de variância dos dados. Devido os dados violarem os pressupostos teóricos dos modelos paramétrico, foi aplicado o teste não paramétrico de Kruskal Wallis $(\alpha=0,05)$. As análises estatísticas e elaboração dos gráficos foram realizadas no software R (R DEVELOPMENT CORE TEAM, 2020).

Figura 1. Zonas da superfície exposta à radiação solar para a avaliação termográfica nos corpos de prova

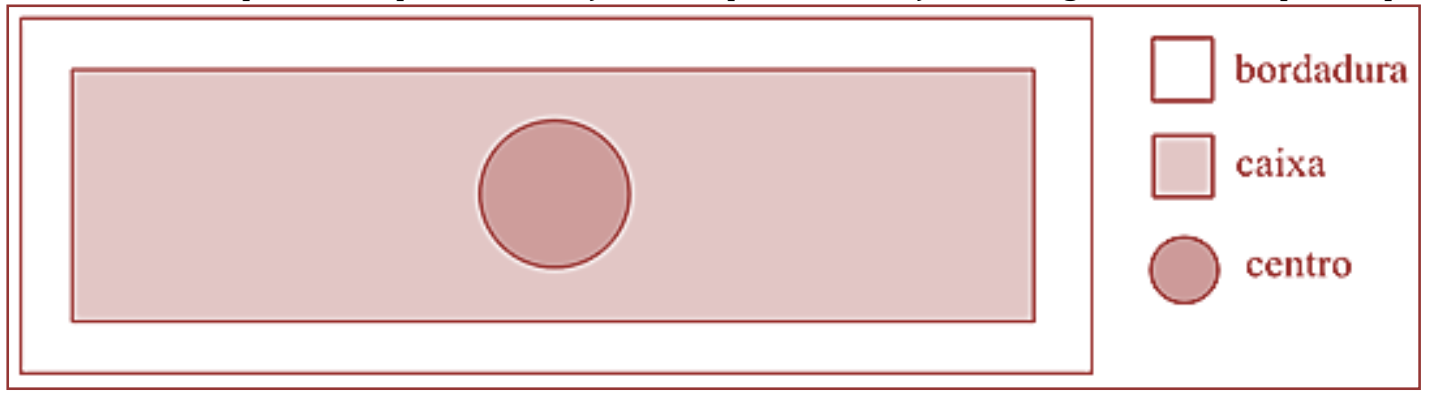

\section{RESULTADOS E DISCUSSÃO}

Todos os materiais apresentaram diferença de densidade (Tabela 1), como era esperado, pois foram selecionados com este propósito. 0 açaizeiro foi o material com a maior variação de densidade e o EPS o de menor variação. Certamente, esta diferença observada na variação dos dados está intimamente ligada à origem de ambos os materiais, enquanto o primeiro foi coletado na natureza sem qualquer tipo de seleção, o segundo provém de um processo industrial que visa propriedades uniformes da produção.

Tabela 1. Densidade Aparente a 12\% de umidade (para os materiais lignocelulósicos). Média \pm desvio padrão; Letras diferentes indicam diferença estatística no teste de Kruskal-Wallis $(\alpha=0,05)$

\begin{tabular}{|l|c|}
\multicolumn{1}{c}{ Tratamento } & $\rho_{12 \%}\left(\mathrm{~g} / \mathrm{cm}^{3}\right)$ \\
\hline Massaranduba & $1,09 \pm 0,02 \mathrm{a}$ \\
\hline Breu & $0,66 \pm 0,01 \mathrm{~b}$ \\
\hline Cedro & $0,55 \pm 0,07 \mathrm{c}$ \\
\hline Açaizeiro & $0,28 \pm 0,13 \mathrm{~d}$ \\
\hline EPS & $0,01 \pm 0,00 \mathrm{e}$ \\
\hline
\end{tabular}

O EPS apresentou as menores temperaturas entre todos os materiais, nas três zonas avaliadas. Este resultado era esperado não só pelo seu amplo uso como isolante térmico, mas também pela sua densidade e sua coloração extremamente clara. Nos materiais lignocelulósicos avaliados, de uma forma geral, quanto mais denso o material, maiores foram as temperaturas observadas na superfície exposta à radiação solar (Tabela 2). A exceção foi justamente o material proveniente da porção central do caule do açaizeiro. 
A Figura 2 traz a imagem térmica de um corpo de prova de cada material avaliado, demonstrando visualmente os resultados apresentados na Tabela 2.

Tendo como referência o EPS, o açaizeiro apresentou média de temperatura 97,65\% superior, seguido da massaranduba, 64,24\%, breu, 53,46\%, e cedro, 46,51\%, na zona caixa, todos foram estatisticamente diferentes entre si. Na zona centro, os resultados seguiram o mesmo padrão, o açaizeiro 87,65\% superior ao EPS, massaranduba $63,97 \%$, breu $58,94 \%$ e cedro $57,92 \%$, com a diferença de as últimas duas madeiras não apresentarem diferença entre si. Na bordadura, houve uma inversão entre açaizeiro e massaranduba, em que a última passou a ter as maiores médias de temperatura e a primeira ocupou o segundo lugar. Os valores foram mais próximos ao do EPS, sendo o açaizeiro 34,99\% superior, massaranduba 31,09\%, breu $29,19 \%$ e cedro $29,62 \%$.

Tabela 2. Temperatura dos tratamentos em diferentes zonas da superfície exposta à radiação solar.

\begin{tabular}{|l|c|c|c|}
\multicolumn{4}{c}{ Temperatura $\left({ }^{\circ} \mathrm{C}\right)$} \\
Tratamento & Caixa & Centro & Bordadura \\
\hline Massaranduba & $50,27 \pm 2,17 \mathrm{~b}$ & $50,46 \pm 2,34 \mathrm{~b}$ & $41,57 \pm 2,56 \mathrm{ab}$ \\
\hline Breu & $48,87 \pm 2,11 \mathrm{c}$ & $48,91 \pm 2,18 \mathrm{c}$ & $40,97 \pm 1,50 \mathrm{~b}$ \\
\hline Cedro & $48,42 \pm 2,26 \mathrm{c}$ & $48,60 \pm 2,25 \mathrm{c}$ & $41,11 \pm 2,33 \mathrm{~b}$ \\
\hline Açaizeiro & $58,07 \pm 4,08 \mathrm{a}$ & $57,75 \pm 4,65 \mathrm{a}$ & $42,81 \pm 2,50 \mathrm{a}$ \\
\hline EPS & $30,77 \pm 1,63 \mathrm{~d}$ & $30,77 \pm 1,56 \mathrm{~d}$ & $31,71 \pm 1,53 \mathrm{c}$ \\
\hline
\end{tabular}

Médias seguidas de letras diferentes indicam diferença significativa no teste Kruskal-Wallis $(\alpha=0,05)$

Figura 2. Imagem de uma linha de corpos de prova (A) e distribuição dos tratamentos no campo (B) indicando respostas térmicas de cada material avaliado

A

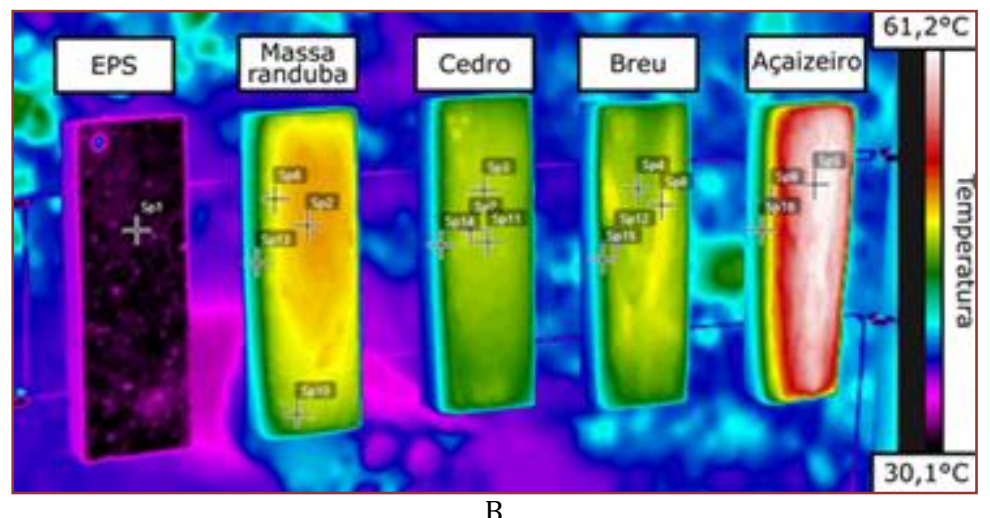

B

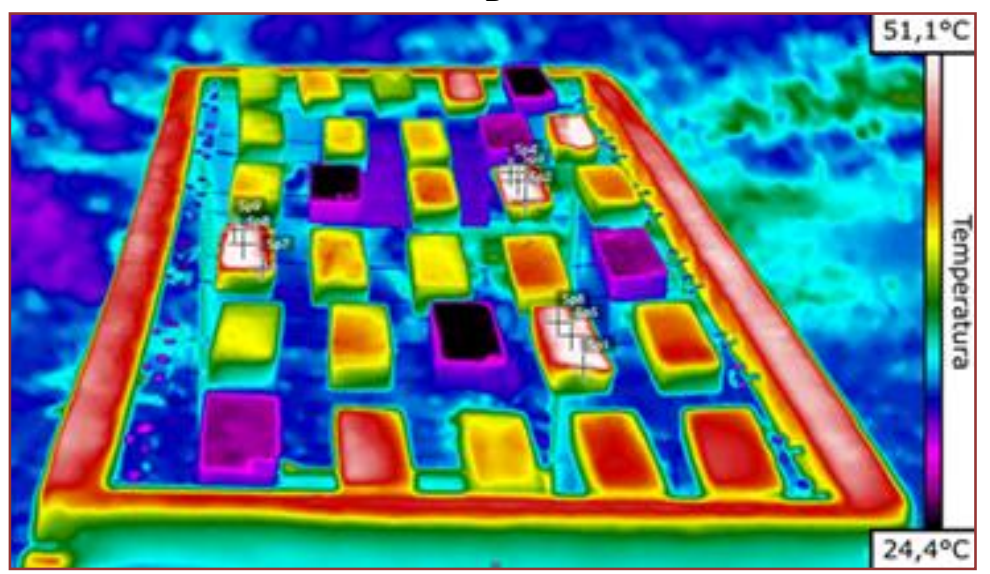


Ao se analisar a distribuição das temperaturas mínimas, médias e máximas em cada espécie, as zonas centro e caixa apresentaram um padrão (Figura 3). As três madeiras são próximas em valores, sendo que as mais densas possuem os maiores valores mínimos, médios e máximos, e a amplitude dos dados é bastante similar. Apesar de o EPS apresentar valores consideravelmente inferiores, a diferença entre mínimos, médios e máximos, bem como suas variações, são próximas às observadas na espécie massaranduba. $\mathrm{O}$ açaizeiro, por sua vez, além de seus valores serem superiores às madeiras mais densas que ele, possui maior amplitude, e maior diferença entre os mínimos, médios e máximos.

Figura 3. Temperaturas Mínima, Média e Máxima por tratamento e zonas da superfície exposta à radiação solar avaliadas

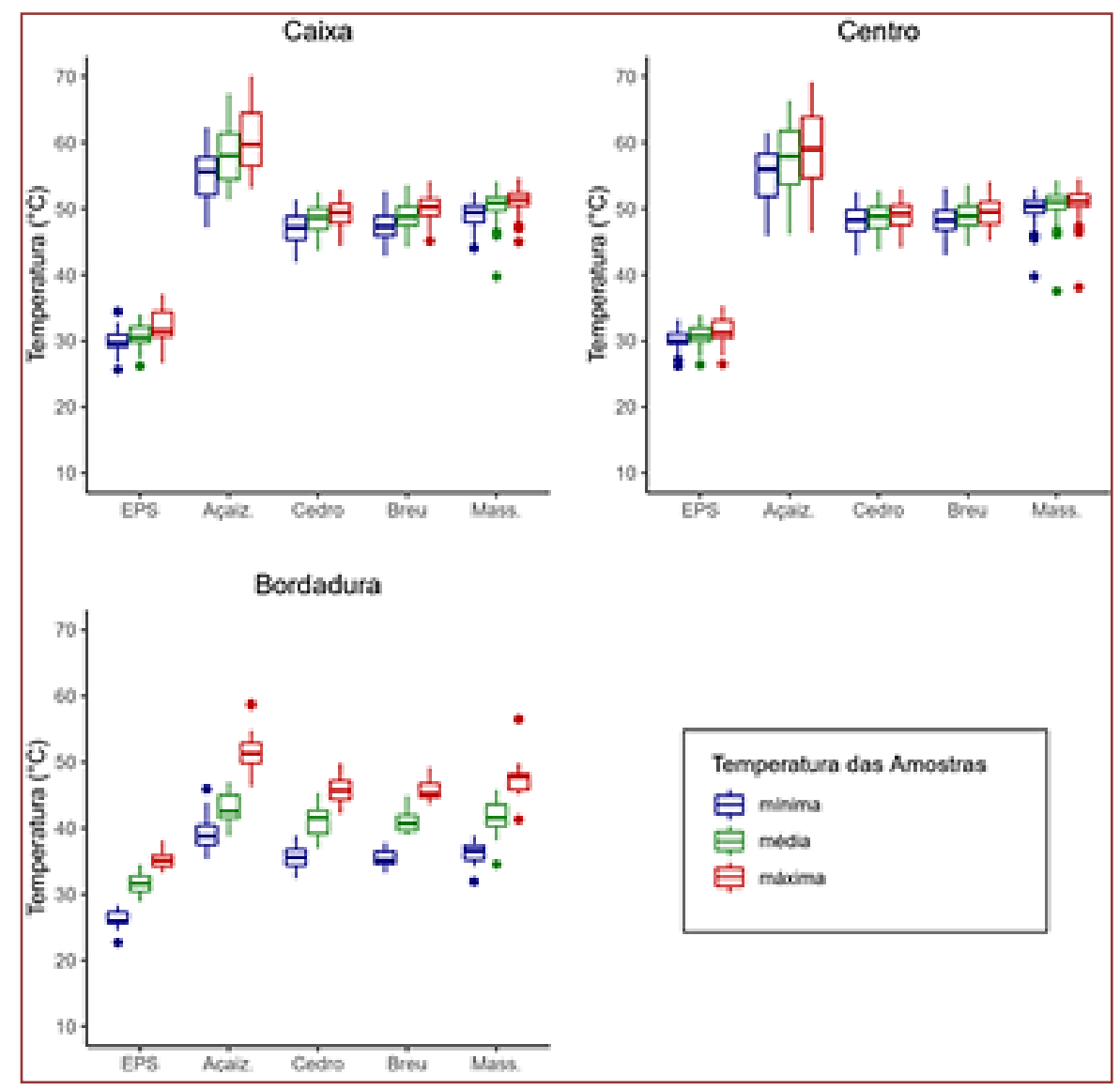

Na porção bordadura, o padrão foi distinto de centro e caixa. Além dos valores dos tratamentos estarem mais próximos entre si, especialmente em relação ao EPS, dentro de cada tratamento os valores mínimos e máximos estão mais distantes dos valores médios. As três madeiras avaliadas possuem valores mínimos e máximos virtualmente na mesma distância em relação aos médios. Já o EPS possui valores mínimos mais afastados dos valores médios do que dos valores máximos, enquanto no açaizeiro, os máximos são os valores mais distantes dos médios. A diferença de comportamento térmico, certamente está atrelada à capacidade de armazenar calor do açaizeiro e a de perder calor do EPS. Estas características dos materiais se tornam mais visíveis justamente na zona da bordadura (Figura 4), onde há maior superfície de contato com o ar ao seu redor. 
Figura 4. Imagem termográfica de uma das amostras de massaranduba (M. huberi) evidenciando sua bordadura com menor temperatura do que caixa e centro

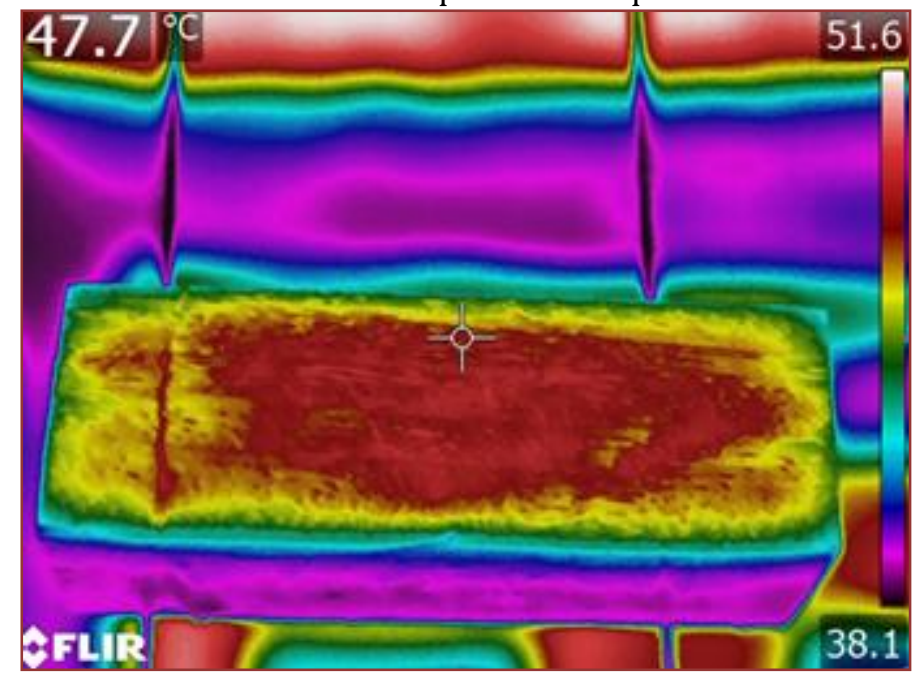

Uma característica importante do EPS para sua utilização como isolante térmico em edificações consiste em apresentar baixas temperaturas quando exposto ao calor. O EPS possui baixa condutividade térmica e, consequentemente, possui característica funcional para utilização com isolante térmico (SANTOS, 2008; OLIVEIRA et al., 2015; NAVROSKI et al., 2010). As espécies madeireiras analisadas, no entanto, apresentam alta densidade quando comparada ao EPS. Como a condutividade térmica da madeira é diretamente proporcional à sua densidade de massa (NOGUEIRA et al. 2004), a avaliação de madeiras de baixa densidade, como Simarouba amara (MARQUES et al. 2004) e Parkia multijuga (CAVALHO, 2009), de densidades 0,39 e 0,44 g.cm-3, respectivamente, podem retornar valores de temperatura mais próximos aos obtidos com o EPS. 0 caule do açaizeiro, apesar de ser também um material lignocelulósico, não seguiu o mesmo comportamento. Embora a zona central do caule do açaizeiro tenha baixa densidade, quando exposto à radiação solar, este material apresentou maior aquecimento do que madeiras de maiores densidades e coloração mais escura.

A presença de sílica na estrutura anatômica de palmeiras é comum (UHL e DRANSFILD, 1987), no formato de corpos silicosos dentro de células denominadas estegmata, adjacentes aos feixes fibro vasculares (SCHMITT et al., 1995). A função da sílica no organismo vegetal consiste em proteção mecânica contra predação e doenças, proteção do tecido quanto ao estresse hídrico e trocas de calor com meio ambiente (SILVA e POTIGUARA, 2009). A presença de sílica foi observada na estrutura interna do açaizeiro (Figura 5) e é, muito provavelmente, a razão da maior absorção de calor solar do açaizeiro quando comparado às madeiras avaliadas.

Também foram encontrados grânulos de amido nas células parenquimáticas do caule do açaizeiro (Figura 5), que possuem um padrão distinto dos corpos silicosos quando observados através de luz polarizada (CHEN et al., 2006). A grande quantidade de amido observada, provavelmente está relacionada à baixa durabilidade da porção central do caule do açaizeiro reportada em Balboni et al. (2018). No presente estudo, não foi observada degradação do material, pois os caules foram prontamente processados e colocados para secar. Esta estratégia pode viabilizar o uso da porção central do caule de açaizeiro, ainda que este não seja adequado para isolamento térmico. 
Figura 5. Corte longitudinal do material proveniente da porção central do caule do açaizeiro, figura com luz normal (A) e com luz polarizada (B), onde são apontados corpos silicosos (seta) e grânulos de amida

(cabeça de seta)

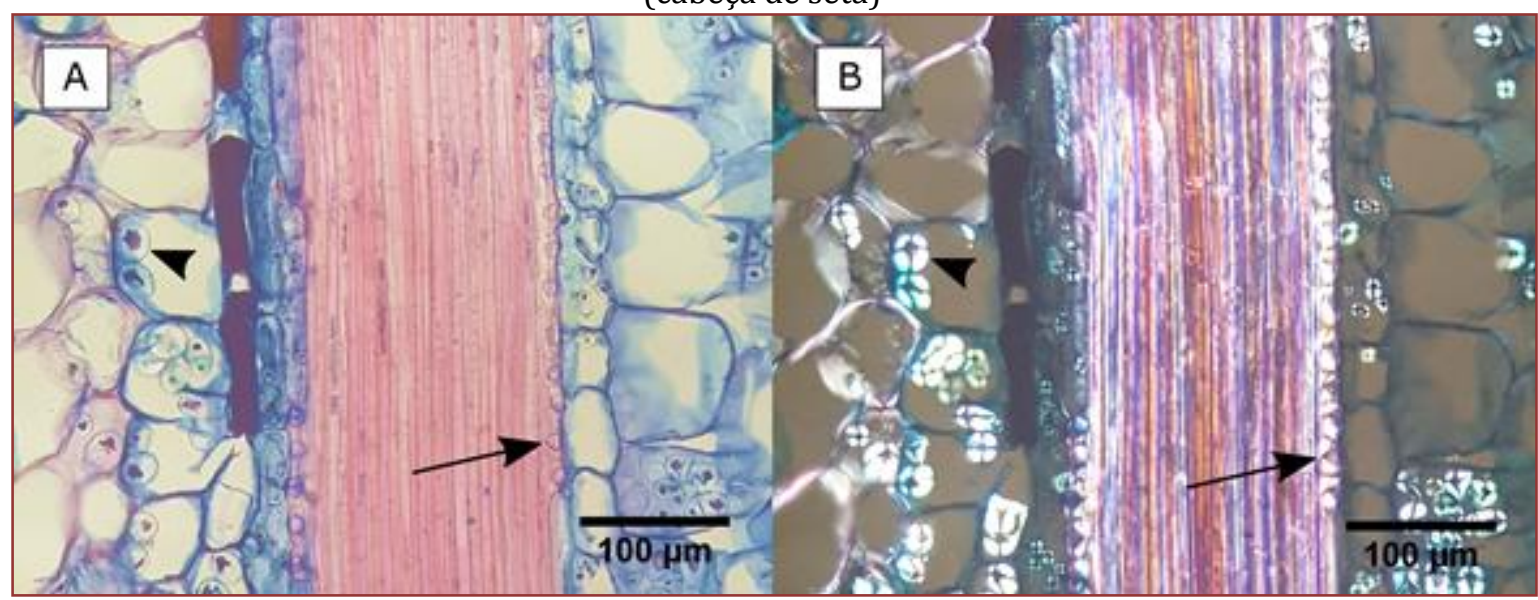

\section{CONCLUSÕES}

Apesar de ser um material lignocelulósico de baixa densidade, a porção central do caule de açaizeiro não se mostrou adequado como isolante. A presença de corpos silicosos nas células stegmata é a provável razão da alta absorção de calor nas amostras de caule de açaizeiro, ampliando-se o potencial bioeconômico dos caules em áreas de manejo de açaizais, principalmente os nativos em que os frutos de açaí participam na renda anual dos ribeirinhos nas áreas de alta ocorrência na Amazônia. Outras aplicações para este resíduo devem ser testadas considerando sua alta retenção de calor e sua atenuação térmica quando não exposto diretamente ao sol.

\section{AGRADECIMENTOS}

À Embrapa Amazônia Oriental, pelo auxílio com as imagens e equipamentos, e ao Laboratório de Tecnologia da Madeira-UFOPA, pelo fornecimento da madeira e do estipe de açaizeiro.

\section{REFERÊNCIAS}

[1] Ambiente $\quad$ Brasil. Isopor $\quad-\quad 0 \quad$ Impacto no Meio Ambiente. $\quad$ Disponível em http://ambientes.ambientebrasil.com.br/residuos/isopor/isopor_impacto_no_meio_ambiente. Acessado em: $28 / 04 / 2017$.

[2] Balboni, B.M.; de Sousa, J.T.R.; Ferreira, M.A.; Rodrigues, R.A.; Macedo, A.B. Residue of açaí berry (Euterpe oleracea) management as a source of lignocellulosic material. European Journal of Wood and Wood Products. ISSN 0018-3768. DOI 10.1007/s00107-019-01417-8.

[3] Calles-Arriaga, C.A.; López-Hernández, J.; Hernández-Ordoñez, M.; Echavarría-Solís, R.A.; Ovando-Medina, V.M. Thermal caracterization of microwave assisted foaming of expandable polystyrene. Ingeniería Investígation y Tecnología, v.17, n.1, p.15-21, 2016.

[4] Carvalho, C.H.R.; Motta, L.A.C. Study about concrete with recycled expanded polystyrene. Ibracon Structures and Materials Journal, v.12, n.6, p.1390-1407, 2019.

[5] Carvalho, P. E. R. Faveira-Benguê-Parkia multijuga. Embrapa Florestas-Comunicado Técnico (INFOTECA-E), 2009.

[6] Calbo, M.E.R.; Moraes J.A.P.V. de. Efeitos da deficiência de água em plantas de Euterpe oleracea (açaí). Revista brasil. Bot., v.23, n.3, p.225-230, 2000.

[7] Chen, Pei et al. Morphology and microstructure of maize starches with different amylose/amylopectin content. Starch-Stärke, v. 58, n. 12, p. 611-615, 2006.

[8] Gerlach, BotanischeMikrotechnik. Georg ThiemeVerlag, Stuttgart. 1984.

[9] Kraus, J. E., Arduin, M. Manual básico de métodos em morfologia vegetal. Rio de Janeiro: EDUR, p.198.1997 
[10] Marques, Marcia Helena B. et al. Efeito da secagem nas propriedades acústicas da madeira de marupá (Simarouba amara Aubl.). Floresta e Ambiente, v. 12, n. 2, p. 57-64, 2014.

[11] Mendes, J. U. L.; Marinho, G. S. Compósito isolante térmico biodegradável. Proceedings of the ENCIT, Caxambu - MG, Brazil - Paper, 2002.

[12] Neto, J.T.F.; Olveira, M.S.P.; Resende, M.D.V.; Rodrigues. J.C. Parâmetros genéticos e ganhos como a seleção de progênies de Euterpe oleracea na fase juvenil. Cerne, v.18, n.3, p.515-521, 2012.

[13] Navroski, M.C.; Lippert D.B; Camargo L.; Pereira M.O.; Haselein C.R. Avaliação do isolamento térmico de três diferentes materiais usados na construção e preenchimento de paredes externas. Ciência da Madeira, v.1, n.1, p.41-51, 2010.

[14] Nascimento W.M.O. do; Silva, W.R. da. Comportamento fisiológico de sementes de Açaí (Euterpe oleracea Mart.) submetidas à desidratação. Rev. Bras. Frutic, v.27, n.3, p.349-351, 2005.

[15] Nogueira M.C.J.A.; Moraes J.G.; Logdson L.; Nogueira J.S. Propriedade térmica: determinação em madeiras nativas do estado do Mato Grosso. In: Conferência latino-americana de construção sustentável, 1; Encontro Nacional de Tecnologia do Ambiente Construído, 10, São Paulo, 2004 ISBN 85-89478-08-4.

[16] Oliveira MSP, Carvalho JEU, Nascimento WMO, Müller CH. Cultivo do açaizeiro para produção de frutos (Cultivation of açaí palm tree for fruit production). Belém, Embrapa Amazônia Oriental, 2002, p 18

[17] Oliveira, W.L.; Xavier A.A.B.; Chaves P.M.F.; Silva L.O. Determinação do coeficiente de condutividade térmica de compósitos constituídos a partir de fibra de coco. In: Congresso Brasileiro de Gestão Ambiental, 5, Porto Alegre, 2015. p.1-10.

[18] Oliveira, M. do S. P. de; Carvalho, J. E. U. de; Nascimento, W. M. O. do. AÇAÍ (Euterpe oleracea Mart.). Embrapa Amazônia Oriental. Belém, PA - 2000.

[19] Samistraro, G.; Muniz G.I. de; Zamora P.P.; Cordeiro G.A. Previsão das propriedades físicas do papel kraft por espectroscopia no infravermelho próximo (nir) e regressão por mínimos quadrados parciais (pls). Quim. Nova, v.32, n.6, p. 1422-1425, 2009.

[20] Santos, R. D. Estudo Térmico e de Materiais de um compósito a base de gesso e EPS para a construção de casas populares. 2008, 92f. (Dissertação de Mestrado), Programa de Pós Graduação em Engenharia Mecânica, Universidade Federal do Rio Grande do Norte. Natal-RN. 2008.

[21] Silva R.J.F.; Potiguara R.C.V. Substâncias ergásticas foliares de espécies amazônicas de Oenocarpus Mari. (Arecaceae): caracterização histoquímica e ultra-estrutural. Acta Amazonica, v. 39, n.4, p.793-798, 2008.

[22] Schmitt U, Weiner G, Liese W (1995) The fine structure of the stegmata in Calamus axillaris during maturation. IAWA J 16(1):61-68

[23] Vital B.R. Métodos de determinação da densidade da madeira. Viçosa, MG: Sociedade de Investigações Florestais, 1984. 21p. (Boletim Técnico, 1).

[24] Uhl, N.W.; Dransfield, J. Genera palmarum: a classification of palms based on the work Harold E. Moore, Jr. Allen Press, Lawrence, Kansas. 1987. 610p. 


\section{Capítulo 12}

Uso de wetland com a macrófita aquática Salvinia sp no tratamento do efluente de parboilização de arroz

Edmilson Cesar Bortoletto

Felipe de Souza Silva

João Vitor Costa de Almeida

Resumo: 0 processo de parboilização do arroz gera grande volume de efluente, que pode causar efeitos negativos nos corpos hídricos e no solo, caso seja descartado sem o tratamento adequado. Diante disso, este trabalho teve como objetivo avaliar o uso da macrófita Salvinia sp no tratamento do efluente de parboilização do arroz em wetland construído. Nos ensaios em escala de bancada foi utilizado um recipiente com volume útil de $7 \mathrm{~L}$, com tempo de detenção hidráulica (TDH) de 3 e 6 dias, sendo mantida constante a vazão por um controlador digital. Cada ensaio foi realizado por um período de 15 dias, coletando-se as amostras do efluente na saída do reator em intervalos de 3 dias. No efluente bruto e nas amostras foram analisados os parâmetros Nitrogênio Total Kjeldahl (NTK), Sólidos Totais (ST) e potencial hidrogeniônico (pH). Os resultados máximos de remoção obtidos de NTK foram de 40\% para o TDH de 3 dias e de 49\% para o TDH de 6 dias. Em relação ao ST, o TDH de 6 dias apresentou uma remoção máxima de $30 \%$ enquanto para o TDH de 3 dias foi de $11 \%$. 0 pH nas amostras, para o TDH de 3 dias, variou entre 6,7 e 6,9 e para o TDH de 6 dias variou de 6,7 a 7,2. Os resultados obtidos indicam que a macrófita flutuante Salvinia sp em sistema wetland pode ser uma alternativa para melhorar o processo de tratamento do efluente de parboilização de arroz, diminuindo os possíveis impactos causados por este efluente.

Palavras-Chave: efluente, wetland, Salvínia sp, parboilização 


\section{INTRODUÇÃO}

A produção de arroz na safra 2019/2020 foi estimada em 11,2 milhões de toneladas, representando aumento de 6,7\% em relação à safra anterior (CONAB, 2020).

A parboilização é um processo hidrotérmico de beneficiamento do arroz, que inclui a gelatinização e a retrogradação do amido, obtendo grãos mais firmes, duráveis e resistentes a quebras, quando comparado ao arroz branco polido (AMATO e ELIAS, 2005), além de ser naturalmente mais nutritivo, pois nenhum composto químico é adicionado ao processo (ABIAP, 2013).

Apesar das vantagens nos valores nutricionais, segundo Queiroz e Koetz (1997), para cada quilograma de arroz parboilizado são gerados em torno de quatro litros de efluente, o que reflete numa grande perda de nitrogênio com o seu descarte em corpos hídricos. Além disso, Sayanthan e Thusyanty (2018) destacam que este efluente apresenta elevado teor de matéria orgânica e inorgânica.

A aplicação deste efluente no solo também deve ser avaliada com cautela. De acordo com Shrivastava et al. (2011), devido aos valores de pH do efluente de parboilização de arroz, entre 4,0 e 5,5, este efluente pode provocar efeitos adversos no solo e em águas subterrâneas.

Desta forma, é de fundamental importância o estudo de processos complementares de tratamento do efluente de parboilização, buscando reduzir os possíveis impactos do seu despejo em corpos hídricos e no solo.

0 uso de wetland pode ser uma alternativa para polimento deste efluente. Segundo Salati et. al. (2009), no wetland com macrófitas flutuantes, o princípio da depuração do efluente se dá devido à adsorção de partículas no sistema radicular, absorção de nutrientes e metais pelas plantas e pela ação de microrganismos presentes na rizosfera.

A macrófita aquática flutuante Salvinia $s p$ tem sido avaliada no tratamento de diversos tipos de efluentes, como por exemplo, de laticínio (Castro et al., 2017), de abatedouro avícola (Carvalho Filho e Bortoletto, 2016), têxtil (Pavithra e Kousar, 2016), apresentando boa eficiência.

A Salvinia $s p$ pertence à divisão Pteridophyta e família Salviniaceae, composta por plantas aquáticas flutuantes, cujas raízes não se fixam em nenhum tipo de substrato, sendo que sua sustentação se dá pela própria água, devido à sua maior densidade em relação ao ar e pela presença de aerênquima na planta (ESTEVES, 2011). Devido ao seu rápido crescimento em condições favoráveis, é importante realizar o manejo adequado da Salvinia sp a fim de evitar uma proliferação indesejada (GOMES, 2011).

Este trabalho teve como objetivo geral avaliar o uso da macrófita flutuante do gênero Salvinia $s p$, no tratamento do efluente de parboilização do arroz em wetland construído.

\section{MATERIAL E MÉTODOS}

Para o tratamento do efluente de parboilização do arroz foi utilizado um sistema de wetland em escala de bancada com a macrófita Salvinia sp. Os experimentos foram executados na Universidade Estadual de Maringá, Campus do Arenito, no município de Cidade Gaúcha - PR, localizado nas coordenadas

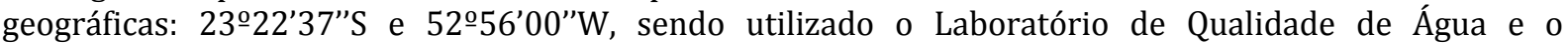
Laboratório de Química para os ensaios e análises.

\subsection{EFLUENTE}

O efluente utilizado foi coletado na saída do decantador de uma indústria de parboilização de arroz localizada na região Noroeste do Paraná. A coleta foi realizada para cada ensaio, a fim de evitar alterações em suas características físico-químicas com o tempo de armazenamento.

\subsection{PLANTA UTILIZADA NOS ENSAIOS EM WETLAND DE BANCADA}

Neste trabalho foi utilizada a macrófita Salvinia sp, representada na Figura 1, a qual foi cedida pelo Horto Florestal da Universidade Estadual de Maringá (Campus Sede), pertencente ao Centro de Ciências Biológicas. 
Figura 1. Macrófita Salvinia sp utilizada nos ensaios.

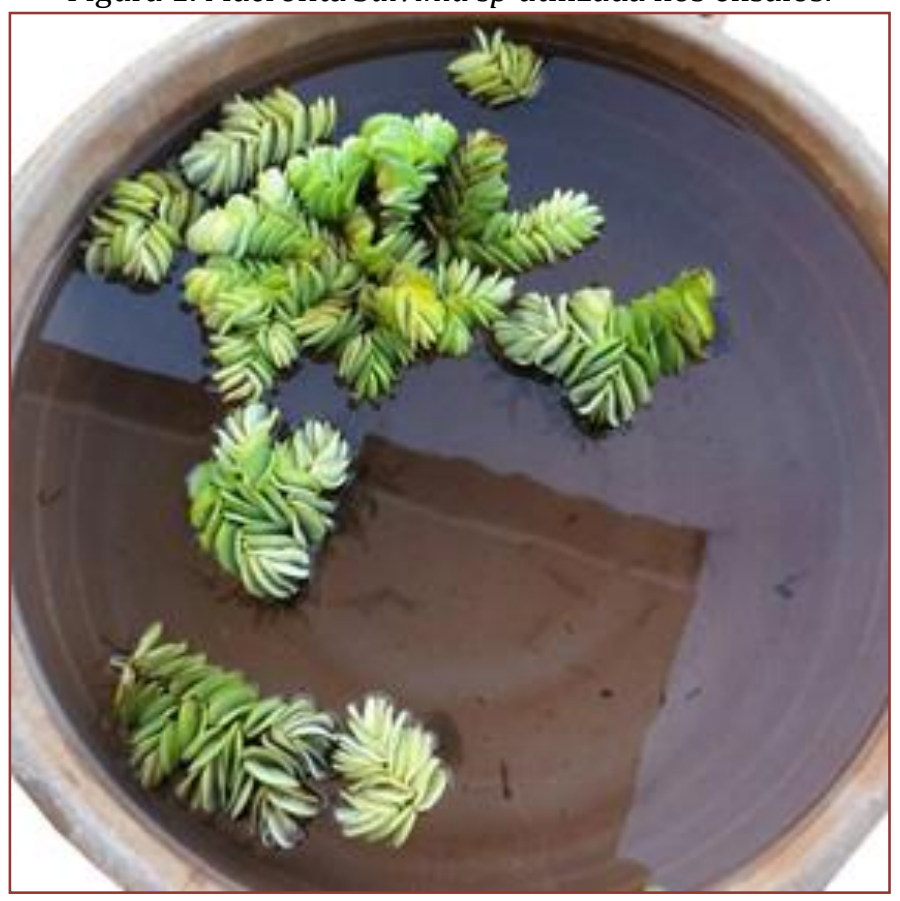

\subsection{MONTAGEM DO SISTEMA DE WETLAND EM ESCALA DE BANCADA COM A MACRÓFITA FLUTUANTE}

0 esquema proposto de wetland construído em escala de bancada para execução dos ensaios está apresentado na Figura 2. 0 sistema contém reservatório de efluente bruto, controlador de vazão digital, reator com macrófitas aquáticas e reservatório de efluente tratado.

Figura 2. Desenho esquemático do processo de tratamento do efluente em wetland.

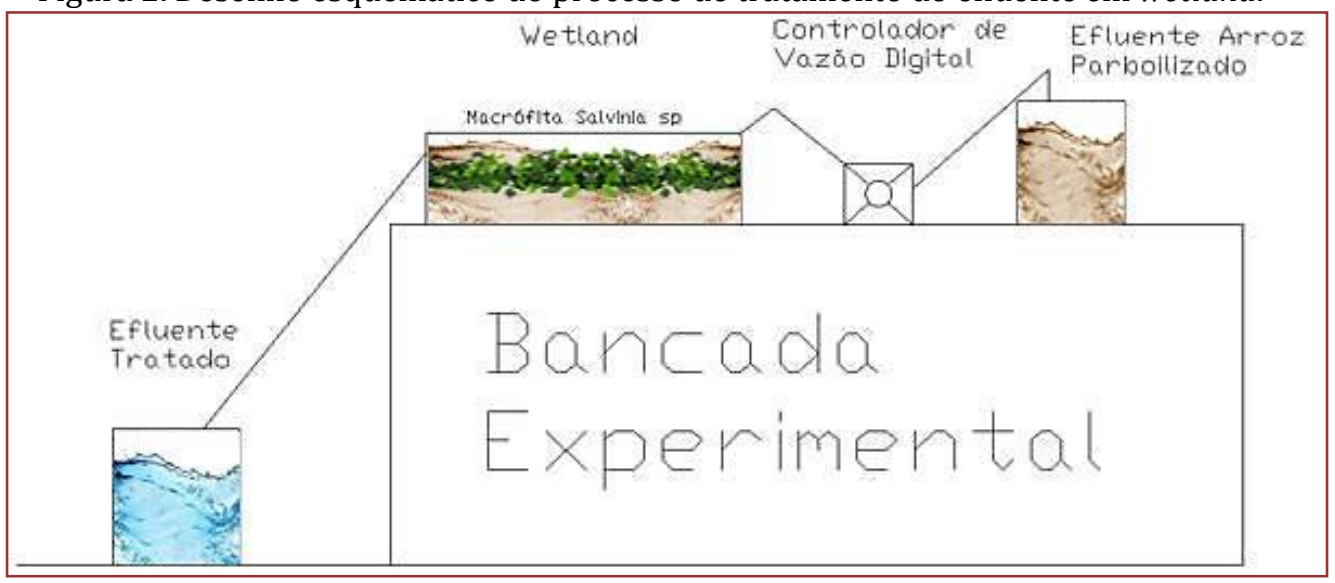

0 reator utilizado no processo de tratamento do efluente apresentava, em sua superfície, $55 \mathrm{~cm}$ de comprimento, $14 \mathrm{~cm}$ de largura, $9 \mathrm{~cm}$ de profundidade (Figura 3). Até o ponto de saída do efluente o volume era de 7,0 L, sendo utilizada a quantidade de plantas necessária para cobrir aproximadamente 30 \% da área superficial. 
Figura 3. Recipiente utilizado para montagem do wetland de bancada.

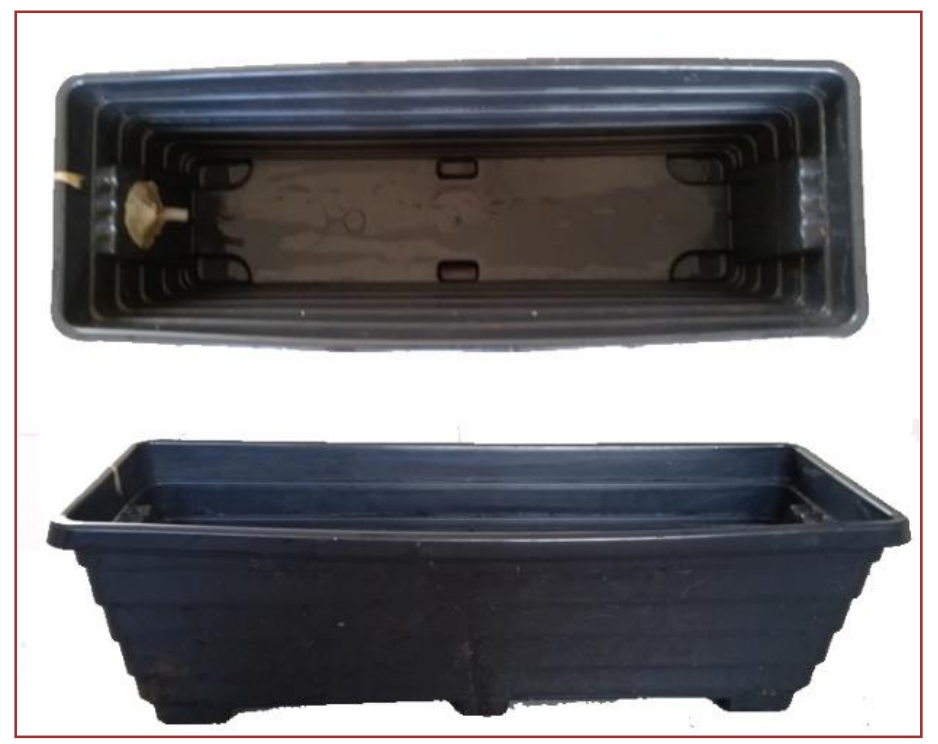

\subsection{TEMPO DE DETENÇÃO HIDRÁULICA (TDH)}

Foram efetuados dois ensaios, o primeiro com TDH de 3 dias que resultou numa vazão de aproximadamente 1,62 $\mathrm{mL} \mathrm{min}^{-1}$ no reator, e o segundo com TDH de 6 dias, resultando em uma vazão de $0,81 \mathrm{~mL} \mathrm{~min}^{-1}$. A vazão estabelecida foi mantida constante por um controlador de vazão digital Provitec DM 5000.

\subsection{COLETA DAS AMOSTRAS NOS ENSAIOS EM WETLAND}

As amostras de efluente tratado foram coletadas em intervalos de 3 dias. Cada ensaio teve um tempo de operação de 15 dias, obtendo-se assim, 5 amostras, as quais foram armazenadas sob refrigeração, para posterior análise no Laboratório de Qualidade de Água e o Laboratório de Química.

\subsection{PARÂMETROS AVALIADOS NO EFLUENTE}

Foram analisados, no efluente bruto e nas amostras coletadas no sistema wetland, o Nitrogênio Total Kjeldahl (NTK), Sólidos Totais (ST) e Potencial Hidrogeniônico (pH).

\section{NITROGÊNIO TOTAL KJELDAHL (NTK)}

Primeiramente foi efetuada a digestão da amostra com ácido sulfúrico concentrado. Em seguida a amostra foi destilada no destilador de nitrogênio, modelo MA-36, Marconi, e depois titulada com solução de $\mathrm{HCl} 0,1$ N. A concentração de NTK foi calculada pela equação (1) seguindo a metodologia APHA (2005).

$$
N T K=\frac{\left(V_{1}-V_{2}\right)}{V} \times N_{a} \times 14000
$$

Em que:

NTK : nitrogênio total Kjeldahl (mg/L);

$\mathrm{V} 1$ : volume da solução de $\mathrm{HCl}$ utilizado para titular a amostra $(\mathrm{mL})$;

V2 : volume da solução de $\mathrm{HCl}$ utilizado para titular o branco (mL);

$\mathrm{V}$ : volume da amostra $(\mathrm{mL})$;

$\mathrm{N}_{\mathrm{a}}$ : normalidade da solução de ácido utilizado na titulação;

A eficiência da remoção de NTK foi calculada a partir da diferença entre o valor encontrado nas amostras do efluente bruto e tratado. 


\section{SÓLIDOS TOTAIS (ST)}

Para a determinação da concentração de sólidos totais foi utilizado o método gravimétrico, descrito por APHA (2005). As cápsulas de porcelana foram submetidas a $550{ }^{\circ} \mathrm{C}$ durante 30 minutos, sendo obtido o peso $1\left(\mathrm{P}_{1}\right)$ após a mesma permanecer em dessecador até atingir temperatura constante. Posteriormente, foram adicionados $8 \mathrm{ml}$ da amostra nas cápsulas, sendo essas levadas à estufa na temperatura de $105{ }^{\circ} \mathrm{C}$ por um período de 24 horas. Em seguida as cápsulas foram colocadas em um dessecador até atingirem temperatura constante, sendo estas pesadas novamente obtendo-se o peso (P2).

0 teor de sólidos totais foi calculado por meio da equação 2 :

$$
S T=\frac{\left(P_{2}-P_{1}\right) \times 1000}{V}
$$

Em que:
ST: Sólidos totais $\left(\mathrm{mg} \cdot \mathrm{L}^{-1}\right)$;
$\mathrm{P}_{1}$ : Peso da cápsula, calcinado em mufla (g);
$\mathrm{P}_{2}$ : Peso da cápsula e amostra após estufa (g);
$\mathrm{V}$ : Volume da amostra (ml)

A eficiência da remoção de ST foi calculada a partir da diferença entre o valor encontrado nas amostras do efluente bruto e tratado.

\section{POTENCIAL HIDROGENIÔNICO (PH)}

Os valores de $\mathrm{pH}$ do efluente bruto e das amostras foram obtidos por leitura direta em pHmetro TEC-3MP, da marca TECNAL. Primeiramente efetuou-se a calibração do aparelho com padrões de pH 4,0 e 7,0, sendo posteriormente realizada a leitura.

\section{RESULTADOS E DISCUSSÃO}

\subsection{REMOÇÃO DE NITROGÊNIO TOTAL KJELDAHL (NTK)}

Nas Figuras 4 e 5 estão apresentados os valores da concentração de NTK, ao longo do tempo, para TDH de 3 e 6 dias, respectivamente. Na Figura 6 estão representadas as eficiências de remoção de NTK para os dois ensaios. 
Figura 4. Comportamento da concentração NTK, utilizando TDH de 3 dias.

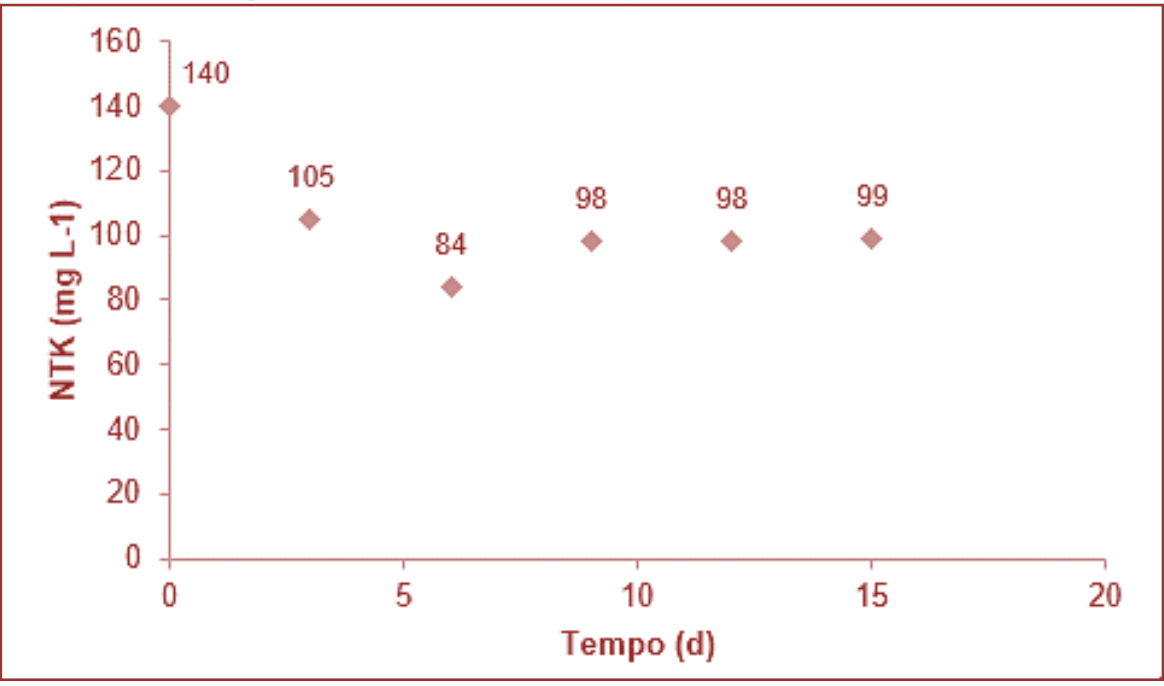

Figura 5. Comportamento da concentração NTK, utilizando TDH de 6 dias.

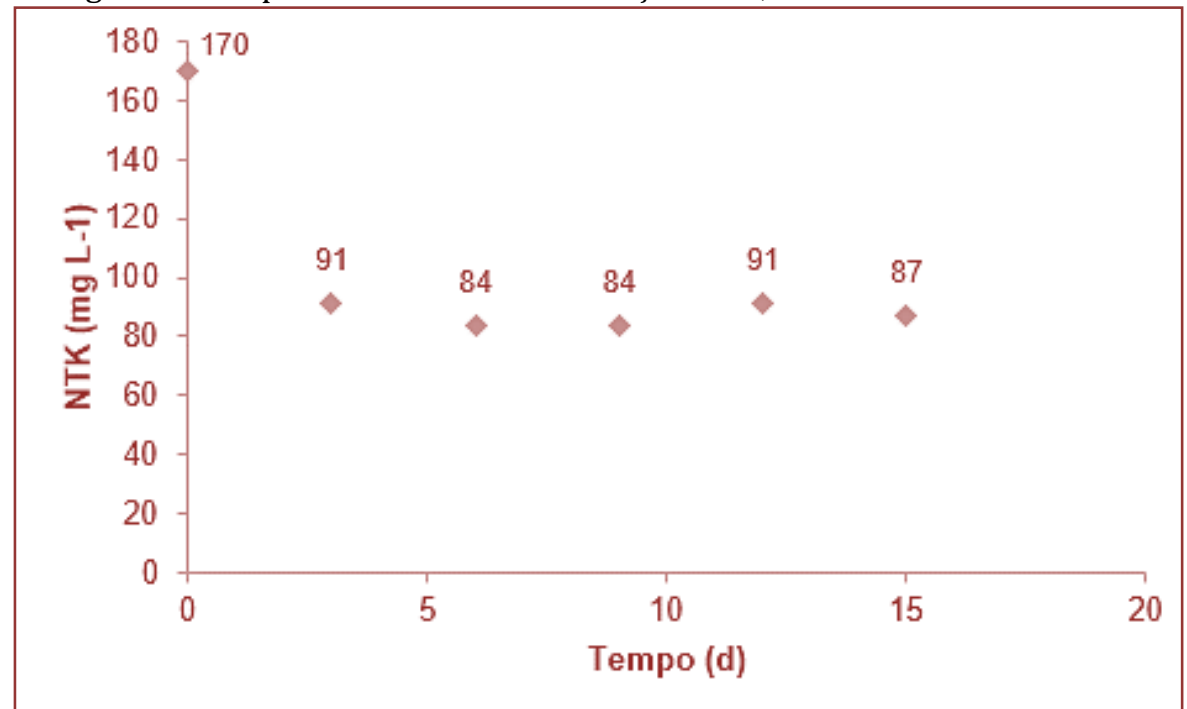

De acordo com as Figuras 4 e 5, verifica-se que o teor de NTK no efluente bruto (Eb) foi de $170 \mathrm{mg} / \mathrm{L}$ no ensaio com TDH de 6 dias e de $140 \mathrm{mg} / \mathrm{L}$ no ensaio com TDH de 3 dias. Essa diferença está relacionada à coleta efetuada em dias distintos, ocasionando esta mudança nas características físico-químicas do efluente. Ressalta-se também que as concentrações de NTK obtidas no efluente bruto estão próximas do valor máximo relatado por Lima (2003), de $141 \mathrm{mg} / \mathrm{L}$. 
Figura 6. Eficiência da remoção de NTK em função do tempo.

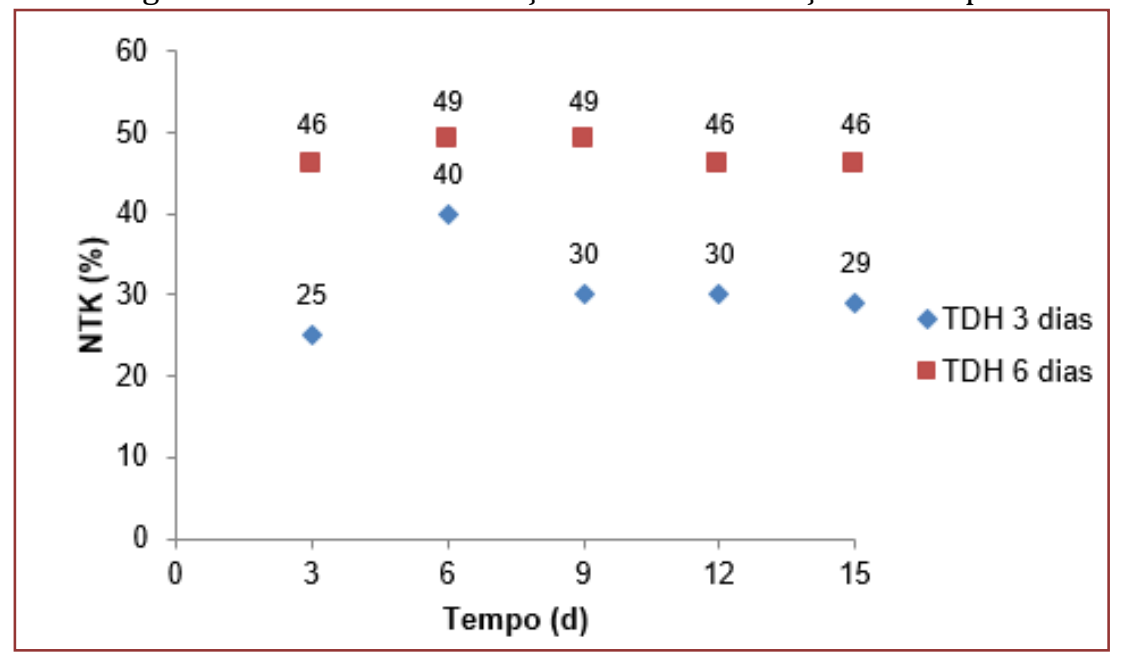

Para o ensaio usando TDH 3 dias, o efluente inicialmente estava a uma concentração de NTK de $140 \mathrm{mg} \mathrm{L-}$ 1 , sendo que após 6 dias obteve-se a maior taxa de remoção de NTK (40\%), atingindo $84 \mathrm{mg} \mathrm{L}^{-1}$ na amostra. No $9^{\circ}$ dia, observa-se uma queda na remoção de NTK, de 40 para 30\%, o que pode estar relacionado à baixa adaptação da planta ao efluente. Na Figura 7 é possível visualizar ao aspecto da planta após 9 dias de ensaio, verificando-se uma alteração significativa em sua coloração.

Figura 7. Salvinia sp após 9 dias de ensaio com TDH 3 dias.

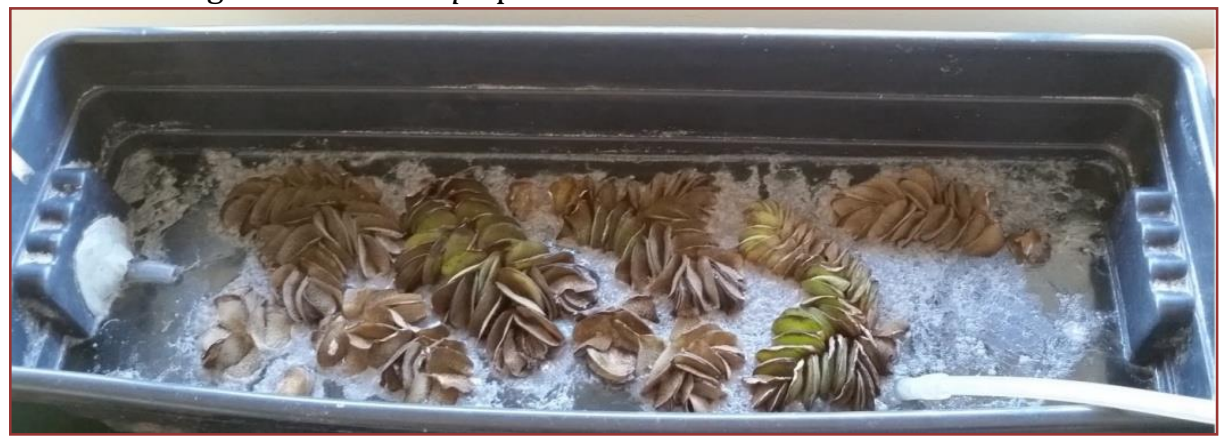

De acordo com as Figuras 5 e 6, utilizando TDH de 6 dias, o efluente inicialmente apresentou uma concentração de $170 \mathrm{mg} \mathrm{L}^{-1}$, e após 6 dias obteve-se a maior taxa de remoção (49\%), atingindo $84 \mathrm{mg} \mathrm{L}^{-1}$ de NTK, permanecendo constante até o $9^{\circ}$ dia. A partir do $12^{\circ}$ dia houve uma leve queda na taxa de remoção, de 49\% para 46\%. Verifica-se na Figura 8 que as plantas utilizadas no ensaio de TDH 6 dias demonstraram maior resistência ao efluente quando comparadas às plantas utilizadas com TDH 3 dias (Figura 7). Além da adaptação das plantas ao efluente, destaca-se também o uso de efluentes com características físico-químicas diferentes, que pode ter influenciado significativamente a eficiência do processo. 
Figura 8. Salvinia sp após 12 dias de ensaio com TDH 6 dias.

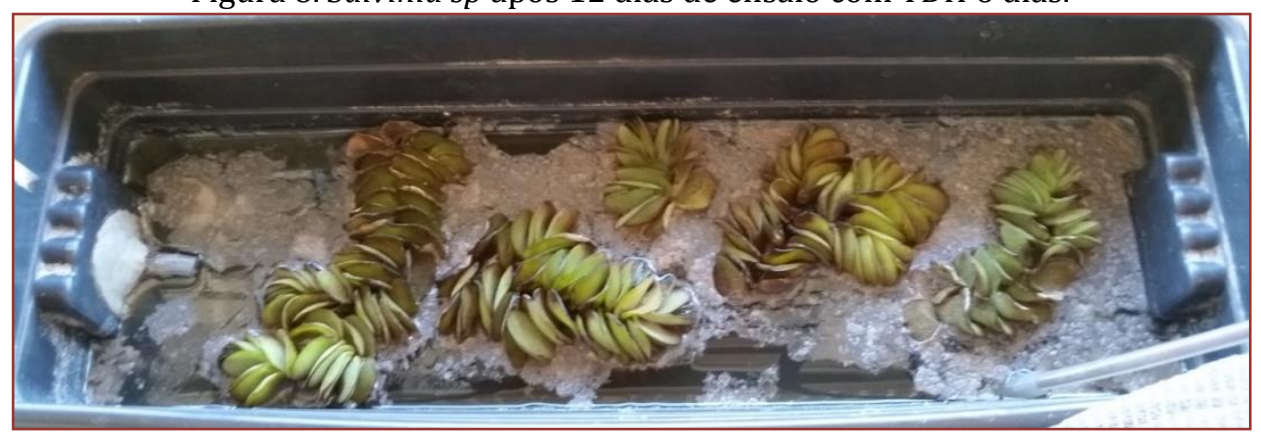

No experimento realizado por Carvalho Filho e Bortoletto (2016), utilizando wetland construído com Salvinia sp para tratamento do efluente de abatedouro avícola com $154 \mathrm{mg} \mathrm{L}^{-1}$ de NTK, atingiu-se remoção máxima de 68\%, operando o sistema com TDH de 12 dias. A menor remoção de NTK obtida no presente trabalho pode estar relacionada ao uso de TDH inferior, o que representa menor tempo de contato entre o efluente e as plantas do sistema.

Utilizando wetland construído com Salvinia $s p$ para tratamento de efluente sintético com TDH de 28 dias, Boschilia (2014) obteve elevada remoção de NTK, de 87 a 91\%. No entanto, o efluente sintético possuía apenas $23,5 \mathrm{mg} \mathrm{L}^{-1}$ de NTK, muito abaixo dos teores encontrados no efluente de parboilização do arroz. Além disso, o TDH estabelecido pelo referido autor foi bem superior aos utilizados neste trabalho, o que também pode ter contribuído para menor remoção de NTK do efluente de parboilização do arroz.

\subsection{REMOÇÃO DE SÓLIDOS TOTAIS (ST) NO EFLUENTE AO LONGO DO TEMPO}

Nas Figuras 9 e 10 estão apresentados os valores médios da concentração de ST.

Figura 9. Comportamento da concentração de ST, utilizando TDH 3 dias.

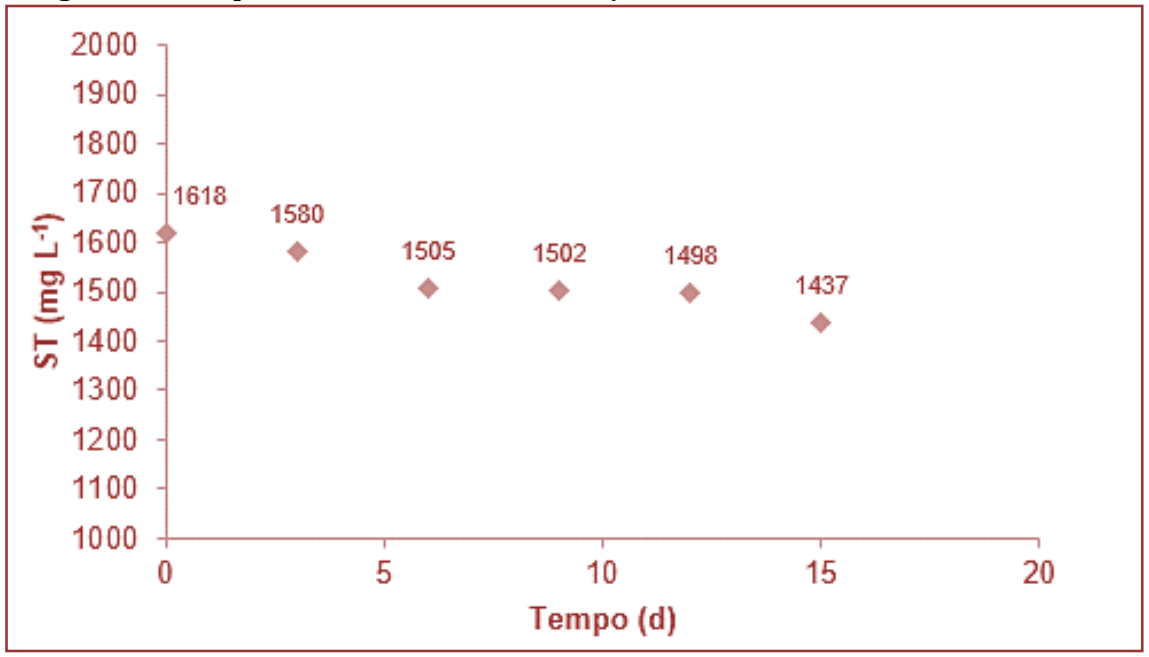


Figura 10. Comportamento da concentração de ST, utilizando TDH 6 dias.

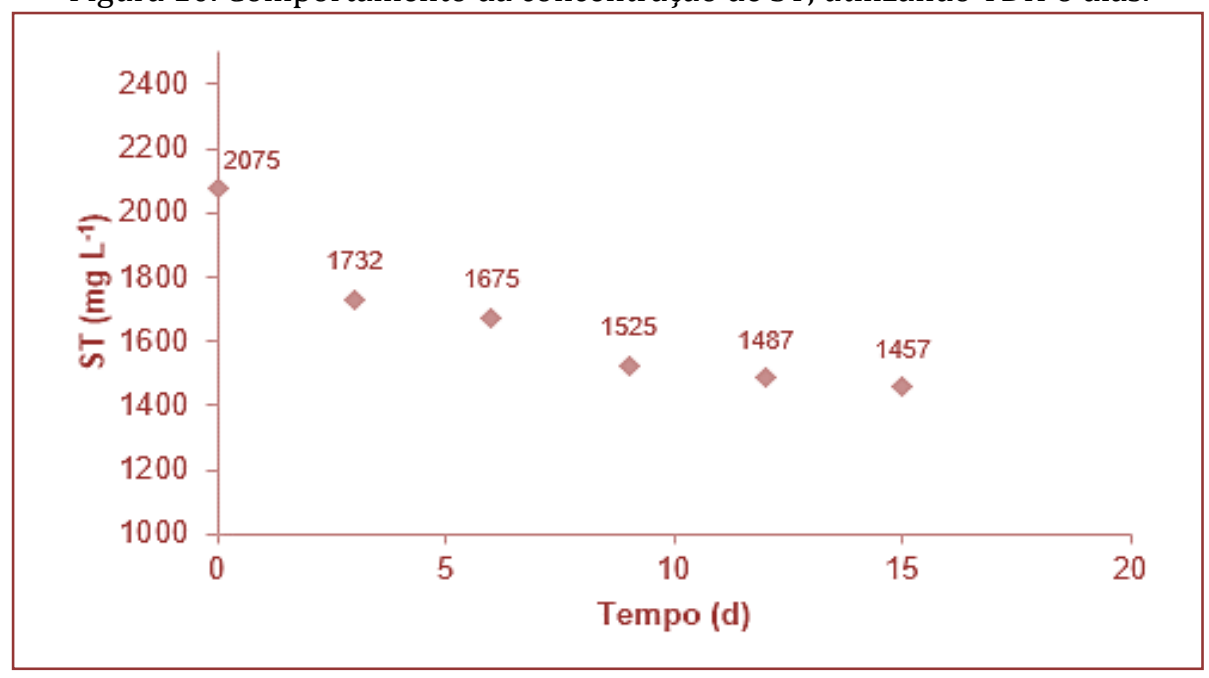

Nota-se nas Figuras 9 e 10 que a concentração de ST no efluente bruto (Eb), no ensaio com TDH de 6 dias, foi superior comparado ao ensaio com TDH de 3 dias, com uma diferença de $457 \mathrm{mg} \mathrm{L}^{-1}$ entre as amostras de Eb.

A Figura 11 mostra as eficiências de remoção de ST em função do tempo.

Figura 11. Eficiência de remoção de ST em função do tempo.

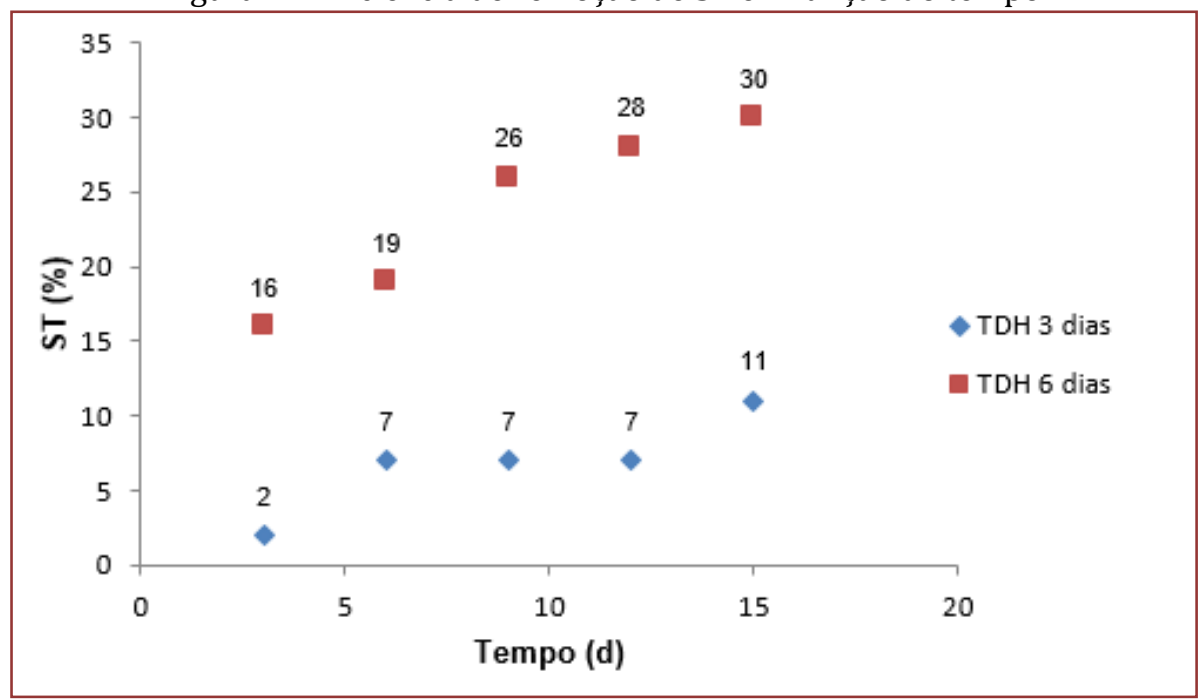

Conforme a Figura 11, no ensaio utilizando TDH de 3 dias, observa-se que houve uma remoção máxima de ST de $11 \%$ após 15 dias, e que entre o $6^{\circ}$ e o $12^{\circ}$ dia a remoção ficou constante, com $7 \%$. Observa-se que no ensaio utilizando TDH de 6 dias, houve uma remoção de ST máxima de 30\%, aumentando gradativamente do $3^{\circ}$ ao $15^{\circ}$ dia.

Dessa forma, o TDH de 6 dias foi mais eficiente na remoção de ST, o que provavelmente está relacionado ao aumento na sedimentação das partículas e maior absorção de sólidos dissolvidos. 


\subsection{COMPORTAMENTO DO POTENCIAL HIDROGENIÔNICO (PH) NO EFLUENTE AO LONGO DO TEMPO}

Na Tabela 1 estão apresentados os valores medidos de pH no efluente bruto e nas amostras em ambos os ensaios.

Tabela 1. Valores de pH nos efluentes bruto e tratado.

\begin{tabular}{|c|c|c|c|}
\hline Amostras & Tempo $(\mathrm{d})$ & $\mathrm{pH}(\mathrm{TDH} 3$ dias $)$ & $\mathrm{pH}(\mathrm{TDH} 6$ dias) \\
\hline $\mathrm{Eb}$ & 0 & 5,3 & 5,7 \\
\hline A1 & 3 & 6,7 & 6,7 \\
\hline A2 & 6 & 6,9 & 7,1 \\
\hline A3 & 9 & 6,8 & 7,1 \\
\hline A4 & 12 & 6,8 & 7,1 \\
\hline A5 & 15 & 6,8 & 7,2 \\
\hline
\end{tabular}

De acordo com a Tabela 1, em ambos os ensaios observou-se significativo aumento do pH na $1^{\mathrm{a}}$ amostra (A1) em relação ao pH do efluente bruto. A amostra A2 apresentou leve aumento no valor do pH, sendo que nas amostras seguintes este parâmetro permaneceu estável.

Os valores de pH encontrados para ambos os ensaios, entre 6,7 e 7,2, estão dentro do limite para que o efluente possa ser lançado nos corpos hídricos, que fica entre 5 e 9, segundo a Resolução no 430/11 do CONAMA (Conselho Nacional do Meio Ambiente). Esse aumento de pH no efluente tratado também pode diminuir os possíveis efeitos adversos no solo.

\section{CONCLUSÃO}

O sistema de wetland para tratamento do efluente de parboilização do arroz, utilizando a macrófita flutuante Salvinia $s p$, demonstrou considerável eficiência na remoção de NTK, atingindo 40 \% em TDH de 3 dias e 49\% em TDH de 6 dias. 0 descarte de efluente com menor concentração de NTK diminui os impactos causados nos corpos hídricos receptores.

Na remoção de ST o ensaio em TDH de 6 dias foi bem superior ao TDH de 3 dias, o que também contribui para diminuir o impacto no corpo hídrico, na medida em que diminui-se o aporte de sólidos.

0 pH do efluente tratado aumentou em relação ao efluente bruto, apresentando valores dentro do permitido em legislação para descarte em corpos receptores hídricos.

Os resultados obtidos nos ensaios sugerem maior eficiência no tratamento do efluente no TDH de 6 dias. Ressalta-se que os ensaios foram realizados com efluentes de coletas distintas, apresentando características físico-químicas diferentes, e que podem ter influenciado os resultados de remoção.

Diante dos resultados apresentados, verifica-se que o sistema wetland com a macrófita flutuante Salvinia $s p$ pode ser uma alternativa como processo complementar de tratamento do efluente de parboilização de arroz, reduzindo o aporte de nitrogênio e sólidos totais ao corpo hídrico. Além disso, destaca-se que o processo com plantas flutuantes, quando comparado a outros tipos de wetland, tem maior simplicidade operacional e menores custos de execução e monitoramento. No entanto, outros parâmetros devem ser analisados no efluente tratado, a fim de atender as legislações ambientais vigentes.

\section{REFERÊNCIAS}

[1] ABIAP - Associação Brasileira das Indústrias de Arroz Parboilizado. Arroz Parboilizado, 2013. Disponível em: www.abiap.com.br. Acesso em: 24/09/2020.

[2] AMATO, G.W.; ELIAS, M.C. A Parboilização do Arroz. 1a ed., Porto Alegre: Editora Ricardo Lenz Ziede, 2005. $160 \mathrm{p}$.

[3] APHA. Standard methods for the examination of water and wastewater, $21^{\text {th }}$. Washington, DC, New York: American Public Health Association, 2005.

[4] BOSCHILIA, O.M. Taxas de remoção de nitrogênio amoniacal, nitrato e NTK por Salvinia Herzogii de la Sota em wetland construído tipo lagoa. Trabalho de Conclusão de Curso. Universidade Tecnológica Federal do Paraná, 2014. 
[5] CARVALHO FILHO, R.; BORTOLETTO, E.C. Remoção de nitrogênio de efluente de abatedouro avícola utilizando wetland construído e macrófitas flutuantes. Centro Científico Conhecer, v. 13 n. 23, p. 1155-1164, 2016.

[6] CASTRO, G. M., SCHWANTES, D., GONÇALVES JÚNIOR, A.C., RICHART, A., VEIGA, T.G., ROSENBERGER, A.G. Treatment of dairy effluents in wetlands systems with floating aquatic macrophytes. Revista de Ciências Ambientais RCA, Canoas, v. 11, n. 2, 2017.

[7] CONAB (COMPANHIA NACIONAL DE ABASTECIMENTO). Monitoramento Agrícola: Acompanhamento da Safra Brasileira - Grãos, V. 7 - SAFRA 2019/20 - N. 12 - Décimo segundo levantamento, SETEMBRO, 2020. Disponível em https://www.conab.gov.br/info-agro/safras/graos. Acesso em: 06/10/2020.

[8] CONAMA no 430, Resolução (2011). Conselho Nacional do Meio Ambiente. Ministério do Meio Ambiente. Disponível em: http://www.mma.gov.br/port/conama/legiabre.cfm?codlegi=646. Acesso em: 24/09/2020.

[9] ESTEVES, F.A. Fundamentos de Limnologia. 3르ed./ Rio de Janeiro: Interciência, 826p, 2011.

[10] GOMES, M. A. C. Efeito da salinidade sobre a biomassa, fisiologia e morfologia de Salvinia auriculata Aubl. 2011, 90 f. Dissertação (Mestrado em Ecologia e Recursos naturais) - Centro de Biociências e Biotecnologia Universidade Estadual do Norte Fluminense Darcy Ribeiro, Rio de Janeiro, Goytacazes, 2011.

[11] LIMA, E.P.P. Pós-tratamento em reator com recheio de pedra calcária de efluentes da parboilização do arroz tratados em reator UASB. 2003. 42 p. Dissertação (mestrado em Ciência e Tecnologia Agroindustrial) - DCTA, Faem, Universidade Federal de Pelotas, Pelotas, 2003.

[12] PAVITHRA, M. e KOUSAR, H. Potential of Salvinia molesta for Removal of Sodium in Textile Wastewater. J Bioremediat Biodegrad,7:5, 2016.

[13] QUEIROZ, M. I.; KOETZ, P. R. Caracterização do efluente da parboilização do arroz. Revista Brasileira de Agrociência, v.3, n.3, p. $139-143,1997$.

[14] SALATI, E, SALATI FILHO, E, SALATI, E. UTILIZAÇÃo DE SISTEMAS DE WETLANDS CONSTRUÍDAS PARA TRATAMENTO DE ÁGUAS. Instituto Terramax - Consultoria e Projetos Ambientais LTDA, 2009. Disponível em: http://arquivos.ambiente.sp.gov.br/pactodasaguas/2011/12/sistema-wetlands.pdfAcesso em: 06/10/2020.

[15] SAYANTHAN, S.; THUSYANTHY, Y. Rice Parboiling and Effluent Treatment Models; a Review. International Journal of Research Studies in Agricultural Sciences (IJRSAS), V. 4, Issue 5, p. 17-23, 2018.

[16] SHRIVASTAVA, P.V., SONI, A.B., KUMAR, H. Treatment of rice mil effluents for pollution control. Jr. of Industrial Pollution Control, 27(1), p 19-22, 2011. 


\section{Capítulo 13}

Respuesta física y fisiológica del cultivo de morera (Morus alba) a dos condiciones de altitud en la cuenca del Rio Guacha en mediaciones del municipio de Belén (Boyacá) y el Encino (Santander) en Colombia

Henry Alexander Reyes Martinez.
Fabio Emilio Forero Ulloa

Marcelo Marinho Viana

Resumen: Con la finalidad de conocer y entender las caracteristicas fisiológica de la Morera (Morus alba) como especie potencial en la implementación de sistemas silvopastoriles en la cuenca del Rio Guacha en limites de Belén Boyacá y Encino Santander se realizo un seguimiento fisiológico de corta duración para observar la respuesta de la Morera con el Entorno donde se iba a establecer las fincas con los nuevos sistemas. Para ello, Las plantas se ubicaron en un vivero temporal a $2700 \mathrm{msnm}$ en la verada Canadá del encino Santander. Se utilizo un Diseño completamente al Azar (DCA) con dos tratamientos y tres repeticiones con un total de 6 U.E. El T1 se ubico en una finca a 2030 msnm con una precipitación máx. de $2400 \mathrm{~mm}$ y min. De $20 \mathrm{~mm}$. Con temperatura promedio de 18oC. El T2 se ubico en una Finca a $2730 \mathrm{msnm}$ con una precipitación máx. de $147 \mathrm{~mm}$ y min de $59 \mathrm{~mm}$ con Temperatura promedio de $14 \mathrm{oC}$. los muestreos destructivos se realizaron cada 30 días y se midió área foliar, peso en seco, peso en húmedo, Tasa De Asimilación Neta TAN, Tasa Absoluta de crecimiento TAC y Tasa Relativa de Crecimiento TRC. En vivero las estacas demoraron 6 meses debido a la no aplicación de enraizante lo que ocasiono la pérdida del 50\% del material y la no homogeneidad de las plantas. Los resultados mostraron que no existieron diferencias estadísticas entre tratamiento 1 y 2 . Sin embargo analizando los resultados de las tasas de crecimiento para el tratamiento 1 , este presenta mayores resultados al estrés climatológico como 18.43 gr, un peso fresco de 38.7.4 gr y un Área foliar de $545.29 \mathrm{~cm} 2$ en un tiempo de 120 días. . Se observa un lento pero positivo crecimiento de la morera a las dos altitudes mostrando una respuesta de un crecimiento morfológico debido a las condiciones climáticas. De acuerdo a los índices fisiológicos esta especie tiene un gran potencial para ser implementada en la Cuenca del Rio Guacha.

Palabras claves: Crecimiento, Morus alba. Tasa relativa de Crecimiento, sistemas silvopastoriles. 


\section{INTRODUCCIÓN}

Para implementar sistemas silvopastoriles y bancos de proteínas como alternativa en una región es necesario conocer las ventajas de ella para la alimentación bovina, conservación de suelo, reducción de la frontera agrícola, uso intensivo y racional del suelo, entre otros. La morera (Morus alba) tiene una gran producción de forrajes, con altas características organolépticas al igual que su consumo por parte del ganado con un contenido proteico de la planta entera de 14 a $22 \%$ de proteína cruda en base seca y digestibilidad de 70 a $80 \%$ (Boschini, 1998), además es una planta de fácil adaptación. Por ello la incorporación de leñosas perennes (arboles y arbustos) en los sistemas de producción ganaderos, como la región de la cuenca del rio guacha, es una estrategia que corresponde a las demandas de seguridad alimentaria de una población creciente, que tiene que ser mas compatible con el uso racional de los recursos naturales( Noda ,2007).

Se habla de adaptabilidad de esta planta forrajera en el trópico, pero no existe ninguna información científica que permita definir cuál es el límite máximo de altitud en el cual se puede desarrollar la Morera. Existen varios artículos científicos sobre fertilización, podas, densidades de siembra, pero ninguna que ayude a determinar la respuesta fisiológica en altitudes superiores de los $2000 \mathrm{msnm}$. Hay especies forrajeras que tienen gran potencial para esta región de la cuenca del Rio guacha pero no han sido estudiadas para su adaptabilidad como sistemas agroforestales o Bancos de proteína en esta region. Para la Morera (Morus alba) los autores basan sus experimentos en condiciones favorables con temperaturas entre 18 a $28 \stackrel{\circ}{\circ}$, precipitaciones anuales de $600 \mathrm{~mm}$ a $2500 \mathrm{~mm}$, alturas entre $1000-1700 \mathrm{msnm}$, horas sol de 9 a 13, (Suttie, 2010). Pero otros autores discuten que su adaptabilidad es tan grande que soporta los $4000 \mathrm{msnm}$ (Benavides, 1995) con buenas producciones, aumentando los tiempos en la época de podas por la producción fotosintética de la planta.

La región, centralizando la transformación de lechera en Belén, Boyacá con la producción de quesos de alta calidad siendo líder a nivel nacional con el queso tipo Pera, su producción de leche proviene de la región media y baja de la cuenca, siendo esta la principal actividad económica de la población rural, por lo que se hace necesario mejorar el sistema de producción a través de la implementación de sistemas silvopastoriles, bancos de proteínas o sistemas agroforestales que ayuden a mejorar la calidad de leche, la cantidad y disminuir sus costos ayudando a la conservación del medio ambiente , que en este caso sería la cuenca del Rio Guacha y que hace parte del último corredor de robles del país

El objetivo de este proyecto es conocer respuesta la física y fisiológica de la morera en dos altitudes (2032, $2734 \mathrm{msnm})$. Determinando area Foliar, Peso en seco, peso húmedo y tasas fisiológicas TAN, TAC y TRC y para la parte física del suelo Estabilidad Estrucutral y Densidad Aparente, con el fin de priorizar la conservación de los recursos naturales y mejorando de la producción lechera y cárnica de la zona de la cuenca del Rio Guacha

\section{MATERIALES Y METODOS}

Este experimento, se llevo a cabo en la cuenca del rio Guacha que está integrada a la zona de "Conservación del corredor de robles de Guantiva-La Rusia-Iguague" que se localizan en la cordillera oriental. Presenta características fisiográficas como relieve escarpado con presencia de fuertes pendientes. En cuanto a ordenes de suelos predomina suelos jóvenes como los inceptisoles y entisoles. El experimento se realizo en dos fincas. La primera ubicada (tratamiento 1) a $2030 \mathrm{msnm}$ en una área determinada como bosque subandino. La segunda finca (tratamiento 2) ubicada a de $2672 \mathrm{msnm}$ en una zona de bosque andino (Fundación Natura). La primera finca ubicada a $2030 \mathrm{msnm}$ tuvo una precipitación máx. $240 \mathrm{~mm}$ y mínima de $20 \mathrm{~mm}$, una temperatura promedio de $18^{\circ} \mathrm{C}$ con vegetación característica de clima medio. La segunda finca ubicada a $2673 \mathrm{msnm}$ y con características de clima frio presento una precipitación máx. de 147 y minina de $59 \mathrm{~mm}$ y una temperatura promedio de $14^{\circ} \mathrm{C}$ La altura fue tomada con GPS.

Tabla 1 Analisis químico del Abono compostado de Gallinaza.

\begin{tabular}{|c|c|c|c|c|c|c|c|c|c|c|c|c|c|}
\hline \multicolumn{14}{|c|}{$\begin{array}{l}\text { ANALISIS ABONO ORGANICO (GALLINAZA) } \\
\text { meq } 100 \mathrm{~g} \text { de suelo }-\mathrm{cmol}^{\mathrm{Kg}^{-}} 1\end{array}$} \\
\hline $\mathrm{pH}$ & $\begin{array}{l}\text { M.0 } \\
\%\end{array}$ & $\begin{array}{c}P \\
(\mathrm{ppm})\end{array}$ & $\mathrm{Al}$ & $\mathrm{Ca}$ & $\mathrm{Mg}$ & K & $\mathrm{Na}$ & CICE & $\mathrm{Fe}$ & $\mathrm{Mn}$ & $\mathrm{Cu}$ & $\mathrm{Zn}$ & $\begin{array}{c}\text { C.E } \\
(\mathrm{ds} / \mathrm{m})\end{array}$ \\
\hline 7,5 & 29,9 & 472 & 0 & 7,64 & 6,39 & 10,1 & 2,77 & 27 & 15,5 & 4,81 & 3,46 & 14,9 & 4,37 \\
\hline
\end{tabular}


El material vegetal fue traído de la Granja Tunguavita de la Universidad Pedagógica y tecnológica de Colombia y llevado al vivero del Experimento ubicado a $2700 \mathrm{msnm}$. Allí se sembró en bolsas de un kilo y se mantuvieron por 6 meses en vivero, A las estacas no se les hizo ningún tratamiento. Se realizo el trasplante en el mes de febrero a cada una de las fincas y se fertilizo con 400 gr de Gallinaza compostada por planta (ver Tabla 1). Cada 30 días se extrajeron muestras destructivas.

Se utilizo un diseño completamente al Azar con dos tratamientos y tres repeticiones con un total de 6 U. E. El tratamiento 1 se ubico a $2030 \mathrm{msnm}$ y el tratamiento 2 a $2730 \mathrm{msnm}$. Cada unidad experimental fue de 300 plantas con una densidad de siembra de $0.80 \mathrm{~m}$ x $0.80 \mathrm{~m}$ con áreas de $176 \mathrm{~m}^{2}$ por cada repetición con un total de $516 \mathrm{~m}^{2}$ por tratamiento de 900 plantas. El área total sembrada fue de $1252 \mathrm{~m}^{2}$ y 1800 plantas. Se define el tratamiento la altura de cada una de las fincas a $2030 \mathrm{msnm}$ y a $2673 \mathrm{msnm}$. Se hizo una aplicación 50 c.c de fertilizante foliar Crecer 500 a los dos tratamientos en los primeros 30 días. Para el análisis de datos se utilizo el programa SPSS versión 17 y se realizaron pruebas de Tukey para identificar diferencias significativas entre tratamientos.

El material vegetal, en este caso las estacas de morera fueron traídas de la Granja experimental Tunguavita de la UTPC de paipa Boyacá ubicada a $2525 \mathrm{msnm}$, con características de 20 a $30 \mathrm{~cm}$ de altura, entre tres y cuatro yemas y de 2 a $4 \mathrm{~cm}$ de grosor, no hubo una homogenización total.

Tabla 2. Tasas de crecimiento

\begin{tabular}{|l|c|c|c|c|}
\multicolumn{1}{c}{$\begin{array}{c}\text { Indice de Crecmiento } \\
\text { Tasa relativa de crecimeinto }\end{array}$} & Nombre & $\begin{array}{c}\text { Formulas de valor } \\
\text { instantaneo }\end{array}$ & $\begin{array}{c}\text { Formulas para valor } \\
\text { neto }\end{array}$ & unidades \\
\hline Tasa de asimilación neta & TAN & D(LNW/Dt) & LNW2-LNW1/T1-T2 & Peso.peso/tiempo \\
\hline Tasa absoluta de Crecimeinto & TAC & (1/AF).DW/DT) & $\begin{array}{c}\text { (W2-W1/T1- } \\
\text { T2).(LNAF2-AF1) }\end{array}$ & Peso.Area/tiempo \\
\hline
\end{tabular}

Para estos datos se utilizo la balanza digital ADAM PGW 2502e, un medidor de área foliar CL-202 área meter C10, INC y una mufla MEMMERT-UNB 500 donde las muestras estuvieron durante 48 horas a $80^{\circ} \mathrm{C}$.

Tabla 3. Analisis Fisico - químicos de suelos de las finca 1 y 2.

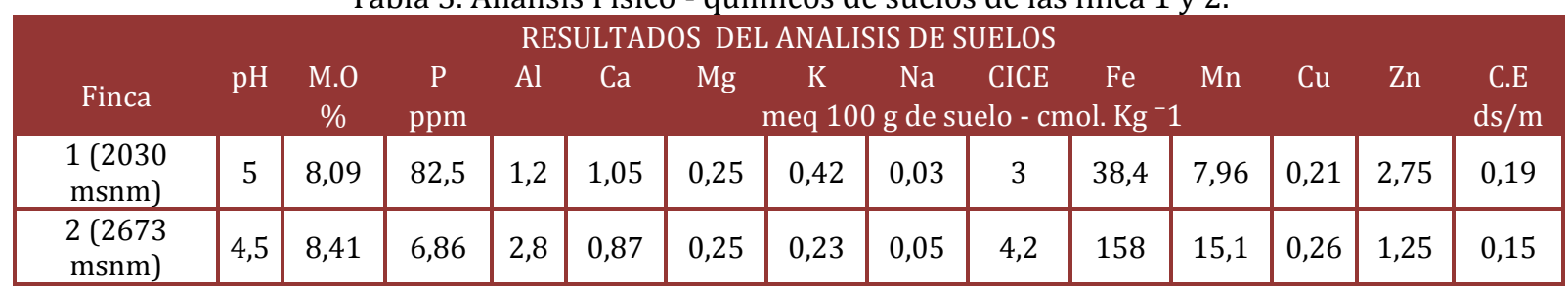

Fuente: Laboratorio de Suelos y aguas de la UPTC

Con estos datos se sacaron los datos para Tasa Absoluta De Crecimiento (TAC), Tasa Relativa de Crecimiento (TRC) y Tasa de asimilación neta (TAN).Para cada finca se realizo dos muestras de suelo. Una para determinar la disponibilidad de nutrientes del suelo y la segunda determinar la estabilidad estructural. Esta se hizo antes y después del experimento.

Para determinar la estabilidad estructural se utilizo el método del terrón y para determinar la densidad aparente se utilizo el método del tamizado , estandarizados para el Laboratorio de Suelos de la UPTC. Para estas pruebas se utilizo una muestra al inicio y al final del experimento, el cual tuvo una duración de 120 días. Las muestras de suelos fueron enviadas al laboratorio de suelos y aguas de la UPTC en Tunja Boyacá. Para los datos de Área Foliar, se utilizo un medidor de área foliar. Se extraían las hojas de los peciolos se colocaban en una superficie blanca en donde era pasado el escáner para conocer los datos. Para el fresco se colocaba la planta en la balanza y se sacaba el dato y para el peso seco de coloco en la mufla por 48 horas y se pesaban para sacar los datos. Los datos eran remplazados en las siguientes formulas: 


\section{RESULTADOS Y DISCUSION}

Los resultados de laboratorio de suelos mostrados en la tabla 6.3 muestran una similitud entre la Finca 1 y la Finca 2. Ambos Suelos presentan una fertilidad baja, son suelos fuertemente ácidos. Hay una diferencia en ppm de fosforo de 82.5 para la Finca 1 y de 8.41 para la Finca 2; de acuerdo a los estándares del laboratorio el porcentaje de M.O es mayor en la Finca 1.

Para la finca 1 mostro una estabilidad estructural de 2.28 ponderado medio que se mantuvo durante el experimento definiéndose como moderadamente estable. Una densidad Aparente de 1,09 grcm3 definido como suelo mineral.

Para la Finca 2 la estabilidad estructural también se mantuvo durante el experimento mostrando un resultado de 2,64 diámetro ponderado medio definiendo como moderadamente estable y una densidad aparente de 1,12 gr cm3 definida como un suelo mineral. Las dos muestran pendientes superior al $80 \%$.

Las observaciones que se hicieron para la estabilidad estructural durante los cuatro meses de estudio no mostraron algún efecto del cultivo hacia el suelo. La principal causa es que el tiempo de estudio es muy corto para obtener un resultado tangible como lo afirma Jaramillo,(2006) que las bondades de estos tipos de alternativas se cuantifican a largo plazo.

Las estacas tuvieron una respuesta positiva como se muestra en la tabla 4 , en donde las condiciones de vivero mostraron que las variables fisiológicas de Área Foliar, Peso Seco y Peso fresco al momento de la siembra eran optimas.. Según Cuellar(2010) en las condiciones de vivero hay una disminución de la luz afectando la fuente de calor y la fuente de energía generando cambios morfológicos y fisiológicos que se muestran en la planta siendo más suculenta (área foliar) y menos lignificada manteniendo un equilibrio alometrico en la acumulación de peso, pero un crecimiento radicular débil y que se expreso a los 30 días de trasplantadas en el campo con los datos negativos.

El hecho que las estacas estuvieran por tanto tiempo en vivero fue una desventaja para el experimento.. Esto se debió a varios factores. Las estacas pasaron de un vivero que estaba a $2525 \mathrm{msnm}$ a $2700 \mathrm{msnm}$ generando el primer estrés climatológico. Además, cuando fueron sembradas en cada chapola no se utilizo ningún enraizante hormonal lo que es imprescindible debido a su sistema radicular que es superficial y relativamente pobre (Enríquez, 2004).

Las estacas tuvieron características morfológicas optimas para el trasplante a campo pero no se presento una uniformidad del $100 \%$. Esto pudo deberse al tiempo de cosecha de las estacas y al lugar de la planta en donde fueron extraídas. La acumulación de carbohidratos en las estacas es probablemente la única fuente de energía para activar el proceso rizogenico (activación auxinas) señalando el almidón para la iniciación y desarrollo del primordio radical. (Enriquez,2004). Boschini (2002) afirma que las estacas de 112 días de edad y extraídas de la parte media y basal de la planta madre muestran un buen nivel de brotación y enraizamiento. Teniendo en cuenta los cambios agroecológicos de la región de estudio, al comparar estos resultados con las observación en vivero, aunque no estuvieran especificados en el experimento, explican uno, la pérdida del material en un 50\% como lo afirma García (2004) y dos el tiempo y la no uniformidad del material y que ayudan a explicar posteriormente los resultados del análisis de crecimiento de la morera.

Durante el periodo 0 días (plantas con las condiciones de vivero) mostrada en la figura 9.1 se observa que y los primeros 30 días la línea muestra una inclinación negativa que está relacionada con el estrés climatológico de la planta a la reubicación en las condiciones de vivero con características de baja intensidad de luz para la fotosíntesis, de riego controlado y condiciones de altitud de $2700 \mathrm{msnm}$ a unas condiciones de campo con una intensidad de luz directa mayor, comienzo del periodo seco y cambios en la temperatura promedio. Esta respuesta es definida por Tudela (1996) , como la acomodación de las plantas en un espacio corto de tiempo debido a varios fenómenos de adaptación provocada por situaciones medioambientales concretas, que en este caso se podría estimar en los primero 30 días aunque puede definirse hasta la primera época de poda de la planta, exististiendo otro periodo de tiempo entre los $60 \mathrm{y}$ 90 días en que el área foliar no tuvo aumento.

Blanco (1992) destaca que en épocas de poca lluvia existe un pobre crecimiento de la morera lo que concuerda con la época seca de febrero (Fundación Narura) y que según el IDEAM hubo un máx. de lluvias de $68 \mathrm{~mm}$ para ese mes. 
Tabla 4. Resultados de Área Foliar, Peso Seco y peso fresco de los tratamiento 1 y 2

\begin{tabular}{|c|c|c|c|c|}
\multicolumn{1}{|c}{ Variale } & $\begin{array}{c}\text { Tiempo } \\
\text { (Días) }\end{array}$ & A.F (cm2) & P.S (gr) & P.F (gr) \\
\hline Vivero & 0 & 180 & 11,34 & 26 \\
\hline T1 & 30 & 109,3 & 9,8 & 19,65 \\
\hline T1 & 60 & 433,2 & 11,19 & 36,5 \\
\hline T1 & 90 & 437,5 & 15,44 & 32,5 \\
\hline T1 & 120 & 545,29 & 18,43 & 38,5 \\
\hline T2 & 30 & 145,37 & 10,1 & 21,66 \\
\hline T2 & 60 & 284,36 & 13,14 & 31,39 \\
\hline T2 & 90 & 310,78 & 14,62 & 31,39 \\
\hline T2 & 120 & 510,92 & 14,73 & 34,64 \\
\hline
\end{tabular}

Adicionalmente esto puede estar relacionado con un efecto estacional, por ser la morera un árbol caducifolio (Penton, 2007).

Figura 1. Variación con el tiempo del Área Foliar (A.F) de Morera para T1 y T2

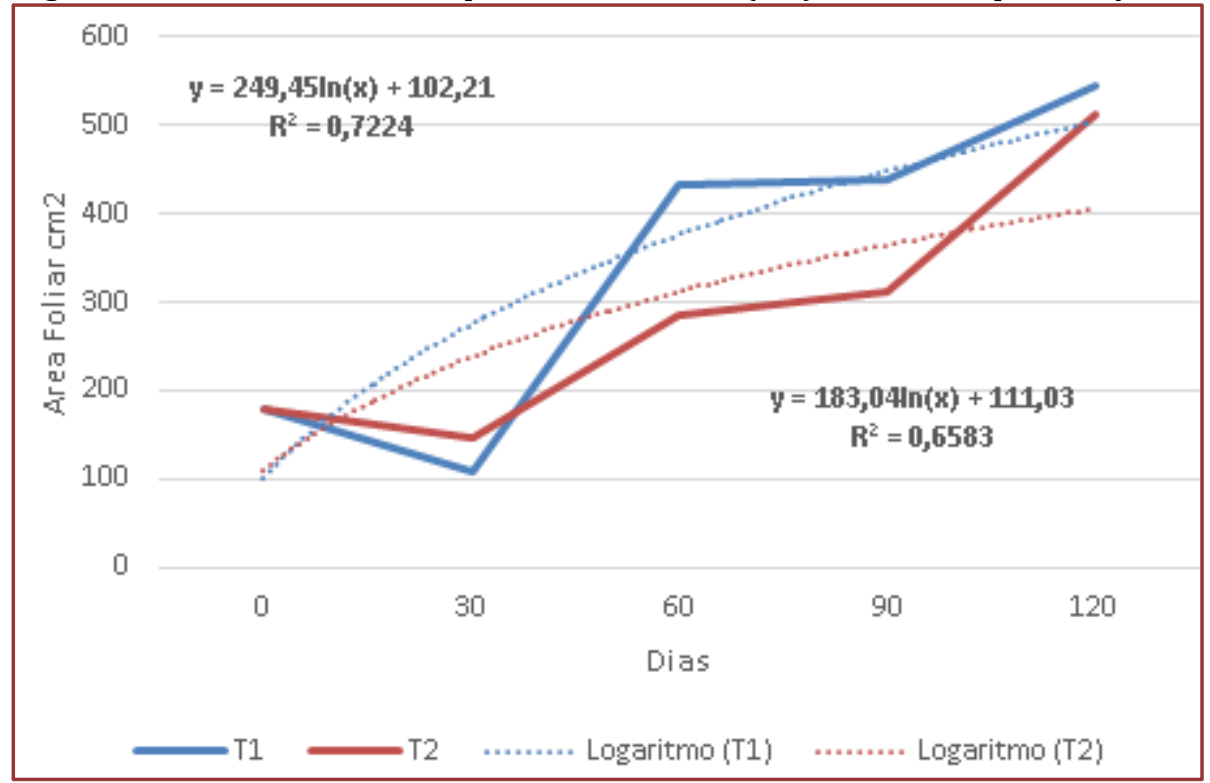

Durante décadas el análisis de crecimiento se ha convertido en una disciplina que relaciona la Eco fisiología y la Agronomía con sus conceptos, términos y herramientas de cálculo (Villar et al,2004) para determinar la velocidad de adaptación de una especie a características agroecológicas diferentes.

Por ello el área foliar tiene gran importancia en los estudios relacionados con su crecimiento y desarrollo, ya que en las hojas se sintetizan los carbohidratos que van a repartiesen en los diferentes órganos (Kozlowski, 1991). La figura 1. muestra un aumento positivo para los dos tratamientos en un periodo de tiempo de 120 días $\left(\mathrm{r}^{2}=0.72\right.$ y $\left.\mathrm{R}^{2}=0.6\right)$ y que se relacionan con el aumento de peso seco y peso fresco mostrado en la figura 2. De un peso Seco de $11.34 \mathrm{gr}$ en vivero a $18.43 \mathrm{gr}$ para T1 y $14.73 \mathrm{gr}$. Sin embargo para el T1 y T2 no existieron diferencias significativas durante los días 60, 90 y 120 días ( Pruebas de Tukey.) para las variables de Área Foliar, Peso seco y peso fresco comparadas con el factor tiempo. 
Figura 2. Variación con el tiempo peso seco (P.S) de Morera para T1 y T2

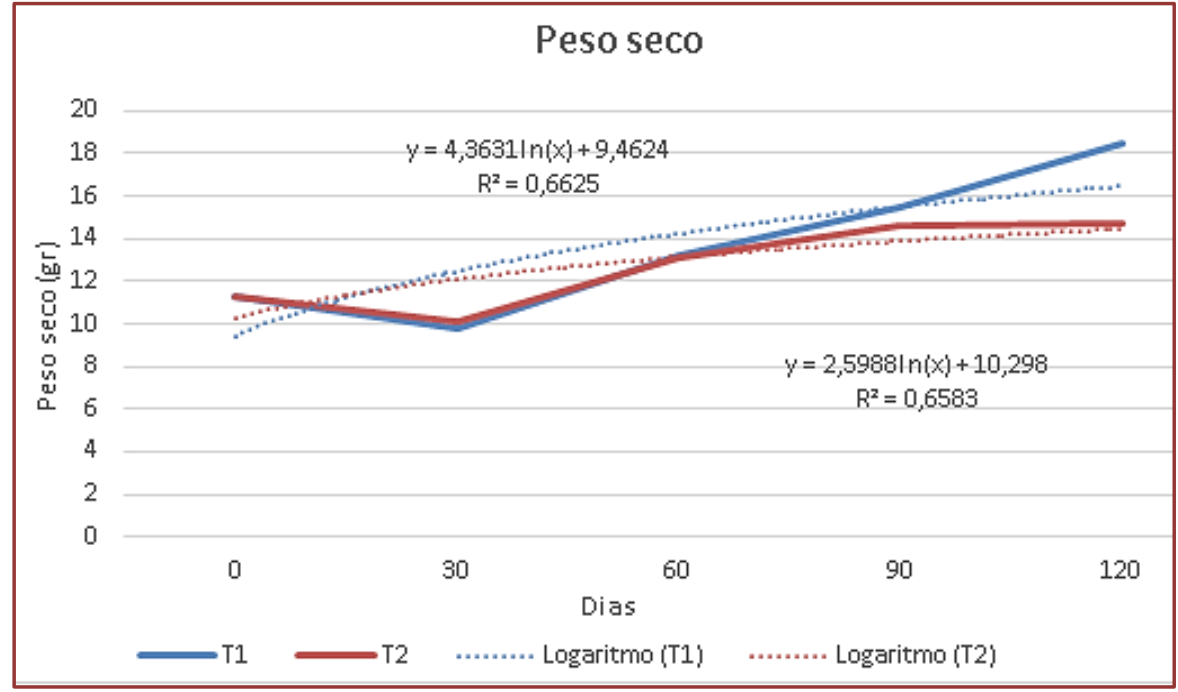

Figura 3. Variación de tiempo y peso fresco de Morera para cada tratamiento

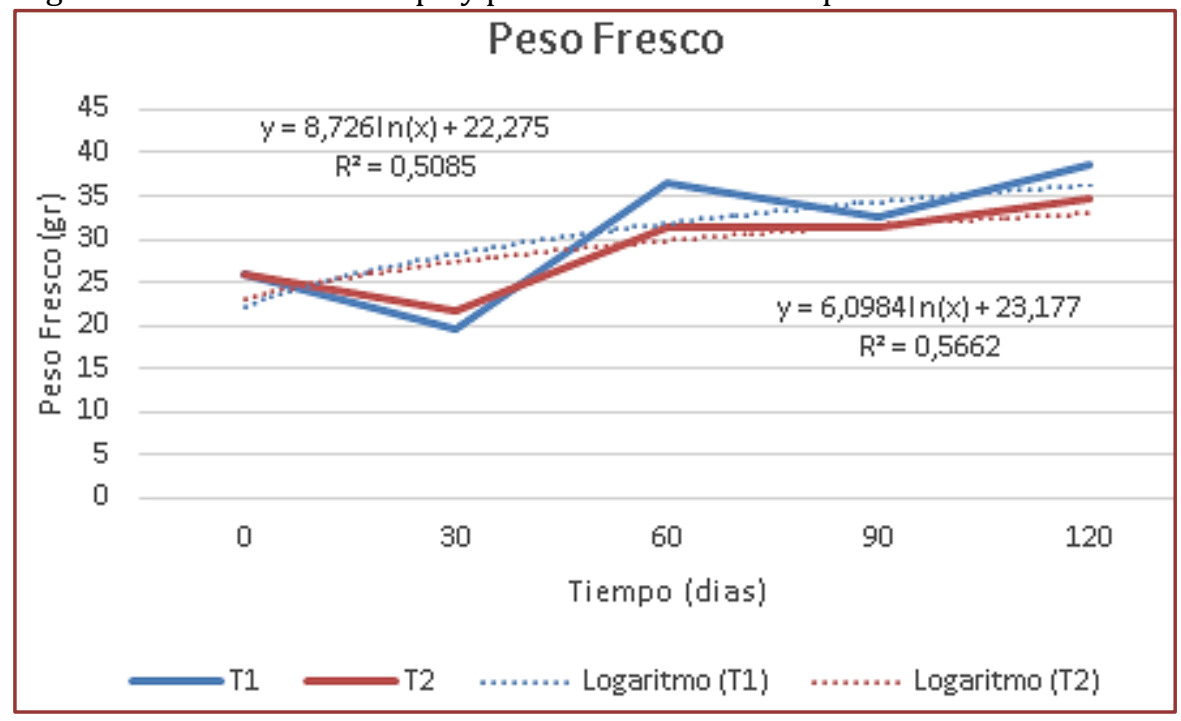

Las tasa relativa de crecimiento TRC y la tasa absoluta de crecimiento TAC son componentes morfológicos del crecimiento que evaluación la ganancia de masa seca en un determinado tiempo y el TAN es el componente fisiológico del crecimiento y es el resultado de la relación perdida y ganancia de la fotosíntesis y la respiración de las hojas, tallos y raíces (Poorter, 1990). Al realizar el ANAVA no se encontraron diferencias significativas en los tratamientos 1 y 2 para las tasas de crecimiento (TRC, TAC, TAN) con respecto a al factor tiempo mostrado en las figuras 4,5 y 6.

De acuerdo a esos resultados se realizo una correlación entre la TAC y la TAN para el tratamiento 1 y 2 dando como resultado un $\mathrm{R}^{2}=0.90$ y un $\mathrm{R}^{2}=0.82$ tendencia de la planta a tener un crecimiento morfológicos en ambos casos, pero es más evidente en el tratamiento 2 pues las condiciones son más adversas y la planta dedico más energía a ser tolerante al estrés climatológico de la montaña como la nubosidad, ocasionando que la baja luminosidad cobre mayor importancia en la morfología de la planta en donde existe complicaciones para aumentar la TAN al derivarse nitrógeno foliar para la captura de fotones (Villar Et al, 2004). 
Estos resultados pueden ser comparados con el estudio de Espinosa (1998), sobre efecto de sitio y fertilización sobre la producción y calidad de la morera en donde temperaturas bajas y mayores nubosidad ocasionaron un limitante crecimiento a la planta y la lignificación de esta.

Figura 4. Comparación de las TRC de T1 y T2 con la variación del tiempo

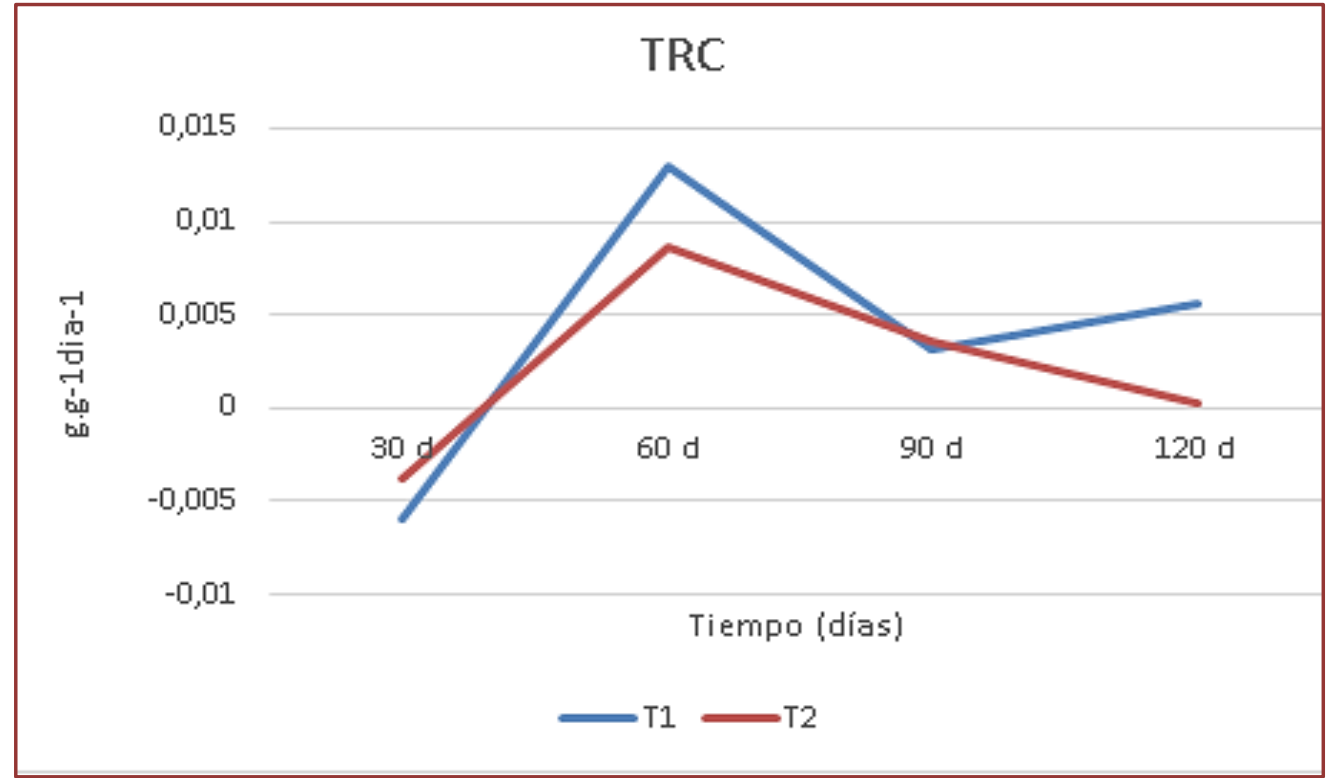

De acuerdo con Reich (1992) los arboles caducifolios presentan un tasa relativa de crecimiento de 50 mg g-1 dia $^{-1}$ que comparada con los resultados de los tratamientos 1 y 2 el resultado máximo fue de 12 $\mathrm{mg} \mathrm{g}^{-1} \mathrm{dia}^{-1}$ lo que es relativamente baja pero que responde a los estreses medioambientales a las que fueron expuestas, en el contenido de citoquininas (Tudela, 1996).

En un estudio que hizo Toral el al (1999) sobre la caracterización de la morera en condiciones de arboretum durante los primeros 60 días las plantas mostraron un crecimiento lento pero que no afecto el establecimiento rápido del cultivo.

Figura 5. Comparación de las TAC de T1 y T2 con la variación del tiempo

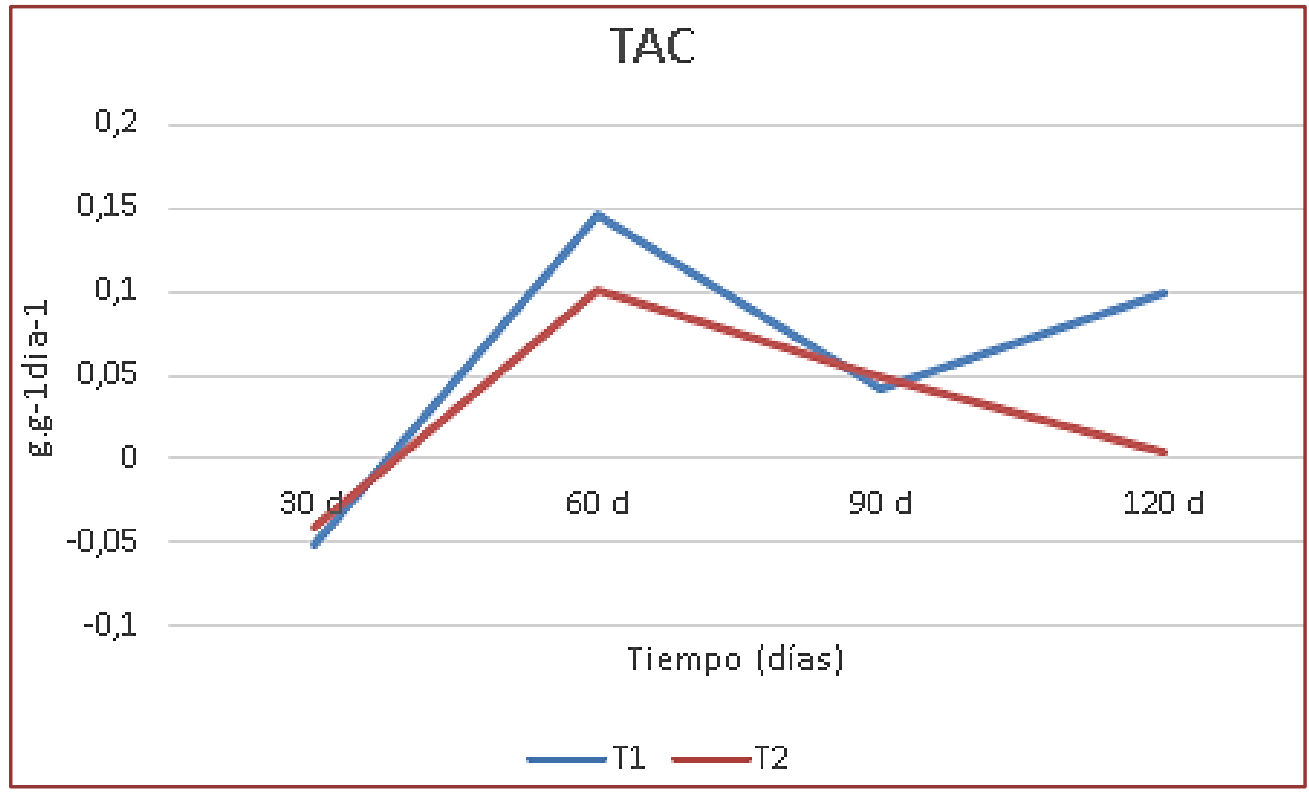


Figura 6. Comparación de las TAN de T1 y T2 con la variación del tiempo

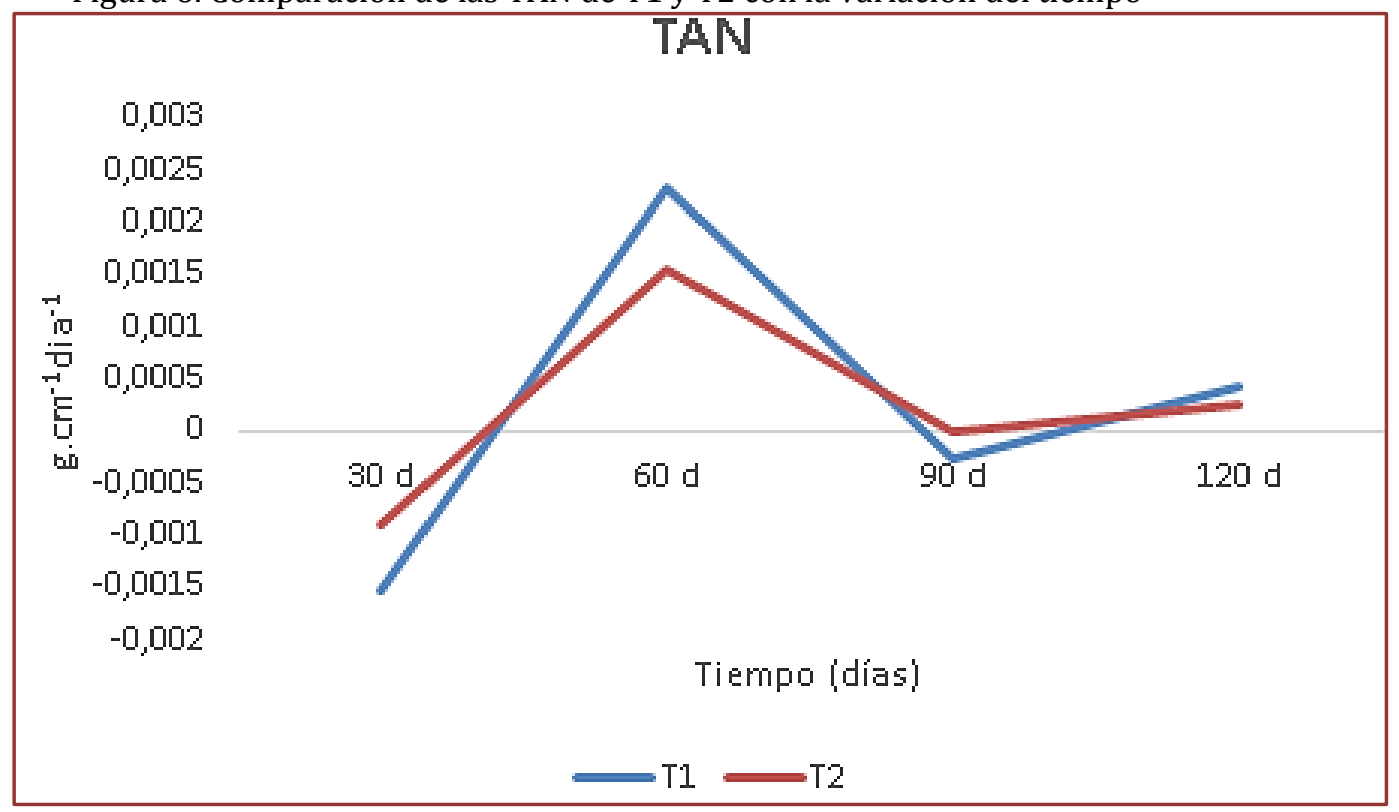

Se evidencio un positivo y lento crecimiento en los dos tratamientos, pero el Tratamiento 1 mostro mayores resultados en Área Foliar, Peso seco y peso freso básicos para la implementación de un sistema silvopastoril intensivo aunque no se encontraron diferencias estadisticas significativas entre tratamientos 1 y 2 para TAC, TAN y TRC, por lo que es necesario evaluar el tiempo de acomodación de 4 meses a un año.

Hay dos factores importantes que determinan la productividad de la morera, el clima y la fertilidad (Espinosa, 1999). Aunque el experimento no tuvo un objetivo especifico en la respuesta a la fertilidad se hace una observación a la aplicación de gallinaza compostada que se aplico (Tabla 1) , mostrando pocos resultados debido a dos cosas. La primera al bajo crecimiento radicular que mostro las plantas durante los 6 meses de vivero y la no aplicación de enraizante; y segundo al tiempo en que la raíz tardo en llegar al abono. La aplicación de 50 c.c de Crecer 500 respondió positivamente durante los primeros 30 días y se ve reflejado en los resultados de Área Foliar, peso fresco y peso seco en los dos tratamientos 1 y 2.

Es necesario continuar con mas estudios fisiológicos y de fertilización en la región para conocer más experiencias de este cultivo en la cuenca del rio Guacha y su adaptación.

\section{CONCLUSIONES}

De acuerdo a las tasas evaluadas para los dos tratamientos la Morera mostro un Crecimiento morfológico debido a las condiciones climatológicas de la región, donde la planta invirtio mas energía en defender la planta para su acomodación y adaptación.

Las plantas de morera sufren un proceso de acomodación debido al estrés climatológico, lo que ocasiono el lento pero positivo crecimiento. Aunque no se encontraron diferencias estadísticas entre los dos tratamientos debido al corto tiempo de estudio, es una planta que tiene gran potencial en la Región para ser implementada como alternativa forrajera para la región de la cuenca del Rio Guacha.

El corto tiempo de estudio no posibilito observar los cambios estructural del suelo con la implementación del cultivo de morera. Es necesario que este estudio tenga mayor tiempo donde exista un crecimiento prolongado superior al año para esta región. 


\section{LITERATURA CITADA}

[1] Benavides, J. 1995 Manejo y utilización de la morera (Morus alba) como forraje. En: Agroforesteria en las Américas, Año 2 No. 7. Costa Rica.

[2] Blanco, R. 1992. Distancia de siembra y altura de corte en la producción y calidad del follaje de morera (Morus sp.) en el parcelamiento Cuyuta, Escuitia, Guatemala. Tesis Lic. Zootec. Universidad de San Carlos. Guatemala. 150 p.

[3] Boschini, C., H, Dormond y A, Castro.1998. Producción de Biomasas de Morera (Morus alba) en la meseta central de Costa Rica. En: AGRONOMIA MESOAMERICANA vol. 9(2). 31-40p. Costa Rica.

[4] Boschini, C. 2002. Nutritional quality of mulberry cultivated for ruminant feeding. . In: Mulberry for animal production. Animal Production and Health Paper. FAO, Rome.

[5] Cuellar. N.D y J.M Arrieta. 2010. Evaluación de respuestas fisiológicas de la planta arbórea Hibiscus rosasinensis L, (Cayeno) en condiciones de campo y vivero. En: Corporación Colombiana de investigaciones Agropecuaria. 11(1), Colombia. $63 \mathrm{p}$.

[6] Enrique. E. 2004. Evaluación de tres factores de Enraizamiento en estacas de Morera (Morus alba). Memoria de titulo. Facultad de Ciencias Agronómicas.. Universidad de Chile. Santiago. 12 p.

[7] Espinosa, E y J. Benavides. 1998. Efecto de sitio y fertilización nitrogenada sobre lap producción y la calidad de la morera (Morus alba L.). En: livestock reserch for Rural Development.(en línea ) Vol. 10. N0 2 FAO.. http://www.lrrd.org/lrrd10/2/benav102.htm. Consultado: 24 de julio de 2012.

[8] Espinosa, E., J. Benavides y P. Ferreire. 1999. Efecto del sitio y fertilización nitrogenada sobre la producción y calidad del forraje de tres variedades de morera (Morus alba) En: Agroforesteria de las Américas (CATIE). 3(11-12). 24-27p

[9] Fundación Natura. Estrategias de desarrollo sostenible, Corredor de conservación Guantiva - La Rusia - Iguaque. Capitulo 2, pag 24.

[10] García. E. 2004. Evaluación Agronómica de la Morera (morus alba v. cubana) en un suelo ferralítico Ropo Típico. Tesis de Máster: Pastos y Forrajes. Universidad de Matanzas “Camilo Cienfuegos”. Cuba.

[11] Gardner F.P., R.B. Pearce y R R.L Mitchell. 1990. Physiology of crop plantas. Second Edition. Iowa State press, Ames. 327 p.

[12] Jaramillo. C. 2006. Evaluación Nutricional y Agronómica de Morus alba y Sambucus nigra L y su utilización en Alimentos de Rumiantes y Monogastricos. En: Revista de Investigación Universidad de la Salle. Vol. 6 (2). Colombia. 190 p.

[13] Kozlowski,T., P. Kramer y S. Pallarady. 1991. The physiological Ecology of Woody Plants. Academic Press. New York. SP.

[14] Penton,G. 2007 Comportamiento productivo de la morera sometida a dos alternativas de fertilización orgánica. En: Pastos y Forrajes , vol.30. No 4. Cuba.

[15] Poorter. H y C. Remkes. 1990. Leaf area ratio and net assimilation rate of 24 species differering in relative growth rate. Ecologya. 83 p.

[16] Noda, Yolai. Et al 2007. Efecto de dos frecuencias y alturas de corte en la producción de biomasa de morera. . En : Zootecnia Tropical vol. 25(4). 261.268p. Cuba.

[17] Reich, P. B., M. B. Walters, y D. S. Ellsworth. 1992. Leaf life-span in relation to leaf, plant, and stand characteristics among diverse ecosystems. Ecological Monographs 62: 365-392 p.

[18] Suttie, J.M. Morus alba 1. 2010. En: http://www.fao.org/ag/AGP/AGPC/doc/Gbase/data/pf000542.htm. Consulta: 22 de abril de 2010 .

[19] Toral. O., L. Simon y M. Yoayma. 2012.Caracterizacion de Morera en condiciones de Arboretum. En: http://www.fao.org/ag/AGa/AGAP/FRG/AFRIS/espanol/Document/Morera/morera11.htm. Consultado: 25 de julio de 2012.

[20] Tudela. D y F. Tadeo. 1996. Capitulo 27. Respuestas y Adaptaciones de las plantas al Estrés. En: Azcon-Bieto. J, Talom. M. 1996. Fisiología y bioquímica Vegetal. Primera Edición. McGRAW-HILL INTERAMERICANA..España. 537 p..

[21] Villar, R. et al. 2004. Capitulo 7. Tasas de Crecimiento en especies Leñosas: Aspectos funcionales e implicaciones ecológicas. En: Valladares, F. 2004. Ecología del bosque mediterráneo en un mundo cambiante... Ministerio de Medio Ambiente, EGRAF, S. A., Madrid. 191-227 p. 


\section{Capítulo 14}

\section{Tolerância à salinidade, crescimento e produção de manjericão sobre cultivo hidropônico}

\section{Luana Nascimento da Silva}

Odeane Viriato Maia

Luana da Silva Guedes

Luiz Paulo Campos Patrício

Resumo: 0 manjericão apresenta-se como uma planta de grande importância no Brasil devido aos seus múltiplos usos, entretanto estudos sobre a espécie ainda são escassos. Este trabalho foi realizado com o objetivo de avaliar o efeito de diferentes níveis de salinidade no crescimento e nutrição mineral. 0 experimento foi conduzido em casa de vegetação da Universidade Federal do Recôncavo da Bahia, em sistema de cultivo hidropônico. 0 delineamento utilizado foi o inteiramente casualizado $(5 \times 4)$ doses de cloreto de sódio $(0,20,40,60$ e 80 mM) na água de irrigação e quatro repetições. Foram avaliadas as seguintes variáveis: número de folhas, área foliar, volume de raiz, massa seca, altura, teor de clorofila e teor de óleo essencial .Verificou-se que a salinidade proporciona menores produções de massa seca da planta. 0 teor de óleo essencial e o teor de clorofila responderam de forma positiva para as maiores concentrações de cloreto de sódio em relação ao uso de solução nutritiva sem o incremento de salinidade.

Palavras Chave: Estresse salino, nutrição, crescimento. 


\section{INTRODUÇÃO}

0 manjericão (Ocimum basilicum L.) pertence à família Lamiaceae. 0 gênero Ocimum apresenta uma grande diversidade química, sendo considerada uma importante fonte de óleos essenciais de expressivo uso na medicina popular. (VIEIRA; SIMON, 2000). 0 metabolismo secundário produz os óleos essenciais e representa uma interface química entre as plantas e o ambiente circundante, portanto, sua síntese é frequentemente afetada por condições ambientais (NETO; LOPES;2007) tendo portanto um importante papel ecológico. 0 manjericão pode ser usado na indústria alimentícia, de cosmético e como espécie medicinal. As folhas frescas ou desidratadas também são amplamente utilizadas na culinária e como planta medicinal. (FERNANDES ,2014).

A alta concentração de sais é um dos principais problemas relacionados à qualidade da água de irrigação, sobretudo nas regiões áridas e semiáridas onde a alta temperatura e a baixa pluviosidade características de tais regiões, favorecem a salinização da água e do solo. No Brasil, a região nordeste devido às sucessões de estações chuvosas e secas que levam a diluição e concentração dos sais respectivamente e com regime de chuvas concentrado no verão e outono, destaca-se por apresentar elevado nível de salinização dos recursos hídricos e isso reduz o potencial de uso desses recursos para a irrigação. (SUASSUNA. 2002; FIOREZE, et al 2012).

De acordo com Silva et al. (2000), os efeitos da salinidade do solo sobre as plantas se resumem em: efeito osmótico provocado pela redução do potencial osmótico; desequilíbrio nutricional devido à inibição da absorção de outros cátions pelo sódio e o efeito tóxico dos íons de sódio.

A elevada concentração de sais na solução do solo resulta no aumento da pressão osmótica e redução dos potenciais osmótico e hídrico. Assim, a disponibilidade de água e nutrientes para a planta diminui, caracterizando o efeito osmótico. Os processos de absorção, transporte, assimilação e distribuição de nutrientes na planta, também são alterados devido a salinidade de acordo com Farias et al. (2009).

0 transporte e absorção de alguns nutrientes são comprometidos pelo excesso de sais, gerando assim um desequilíbrio nutricional, o que pode comprometer o desenvolvimento do vegetal (FERREIRA et al., 2001; CAVALCANTE et al., 2010).

O objetivo deste presente trabalho foi avaliar a produção de biomassa e os marcadores fisiológicos em Manjericão quando submetido à salinidade e contribuir com os dados literários quanto à tolerância à salinidade da espécie.

\section{MATERIAIS E MÉTODOS}

O experimento foi realizado em casa de vegetação do Centro de Ciências Agrárias, Ambientais e Biológicas - CCAAB no período de maio a julho de 2018,na Universidade Federal do Recôncavo da Bahia - UFRB, Campus de Cruz das Almas-BA, região que possui segundo Carvalho (2010) coordenadas geográficas de $39^{\circ} 06^{\prime} 26$ latitude sul e $12^{\circ} 40^{\prime} 39^{\prime \prime}$ longitude oeste, com altitude de 226 metros. E um clima que de acordo a classificação de Köppen é do tipo tropical quente e úmido. A precipitação média é de 1,224 mm por ano, a temperatura média anual é de $24,5^{\circ} \mathrm{C}$, e a umidade relativa do ar é de aproximadamente $82 \%$.

A espécie utilizada no experimento foi (Ocimum basilicum L.) cujas mudas foram produzidas em bandejas de polietileno de 50 células preenchidas com substrato constituído por fibra de coco, após 15 dias emergidas as plântulas foram transplantadas para os vasos. 0 experimento foi desenvolvido em vasos plásticos com capacidade de 1,5 L, utilizando-se solo como substrato.

O delineamento experimental foi inteiramente casualizado, composto de cinco tratamentos e quatro repetições, totalizando vinte unidades experimentais.

Foram testados cinco níveis de salinidade na água de irrigação $(0,20,40$ e 60 e $80 \mathrm{mM}$ de Nacl) que foram aplicados de forma manual, em quantidade suficiente para o bom desenvolvimento da planta, porém durante os cinco primeiros dias apenas solução nutritiva correspondente a $25 \%$ da solução padrão de Hoagland e Arnon (1950) foi aplicada e posteriormente uma solução correspondente a 75\% juntamente com as doses de salinidade . Após 60 dias com a aplicação dos tratamentos, as plantas foram avaliadas nos seguintes parâmetros: número de folhas, área foliar, volume de raiz, massa seca das folhas, caule e raízes, a altura foi medida com régua a partir do ápice da planta (gema terminal), as plantas foram separadas em folhas, caules e raízes e todo o material foi seco em estufa com circulação forçada de ar a $45{ }^{\circ} \mathrm{C}$, até biomassa constante, utilizando-se de uma balança analítica. 
O índice de clorofila a, b (ICF-índice de Clorofila Falker) foram analisados em três folhas por planta (terço médio, terço superior e inferior ) com um medidor eletrônico de clorofila Falker modelo CFL1030.

A extração do óleo essencial do manjericão foi realizada utilizando $16 \mathrm{~g}$ de folhas e caule devido a baixa produção de biomassa. 0 material foi secos à 45 graus e o óleo foi extraído por hidrodestilação no aparelho de Clevenger. 0 processo foi conduzido durante $2 \mathrm{~h}$, contadas a partir da condensação da primeira gota e o volume de óleo extraído foi verificado na coluna graduada do Clevenger. Com os dados de volume calculou-se o teor do óleo essencial. De acordo com metodologia descrita por Zenebon et al. (2008) , o teor corresponde a razão entre o volume de óleo essencial (ml) destilado pela massa seca (g) da amostra, multiplicada por 100. Os dados coletados foram submetidos a análise de regressão no programa Excel e os dados correspondentes ao teor de óleo foram comparados pelo teste de Tukey(5\%), utilizando o programa estatístico SISVAR 5.3®.

\section{RESULTADOS E DISCUSSÃO}

\subsection{MASSA SECA DE FOLHA, CAULE E RAIZ}

A variável massa seca da folha (MSF) apresentou um comportamento linear decrescente com incremento do cloreto de sódio a solução nutritiva e comparando-se o tratamento controle com o de $80 \mathrm{mM} \mathrm{de} \mathrm{Nacl}$, observou-se uma variação de 3,555g no controle para 2,8125g no tratamento de $80 \mathrm{mM}$, que representa uma redução de 0,00928g por incremento de tratamento salino. Menezes (2017) em estudos com manjericão, para mesma variável, com os mesmos níveis salinos, relatou uma redução de $0,027 \mathrm{~g}$ por incremento de Nacl. As variáveis massas seca da raiz (MSR) e massa seca o caule (MSC) também apresentaram variação com o aumento das doses de salinidade, a redução não foi linear. Os dados estimados para a (MSC) mínima e máxima foram respectivamente de 2,464g (0mM NaCl) e 2,281g $(80 \mathrm{mM}$ $\mathrm{Nacl}$ ) , e para (MSR) o valor mínimo estimado foi de 5,4175g e o máximo de 3,7545g .Deste modo as reduções estimadas foram de 7,43\%, 30,7\% e 21,36 \% para MSC , MSR e MSF respectivamente, supõe-se com os dados apresentados que a raiz foi mais sensível a salinidade do que a parte aérea. 0 abaixamento do potencial hídrico ocasionado pelo incremento de solutos diminui a turgidez dos estômatos ocasionando o fechamento dos poros estomáticos e reduzindo assim os ganhos com carbono na assimilação fotossintética (KERBAUY, 2012), logo a redução na matéria seca é reflexo desse ajustamento fisiológico.

Figura 1.Massa seca da folha de manjericão após 60 dias de cultivo. Os valores indicam médias de quatro repetições e os respectivos tratamentos $(0,20,40,60$ e $80 \mathrm{mMl})$

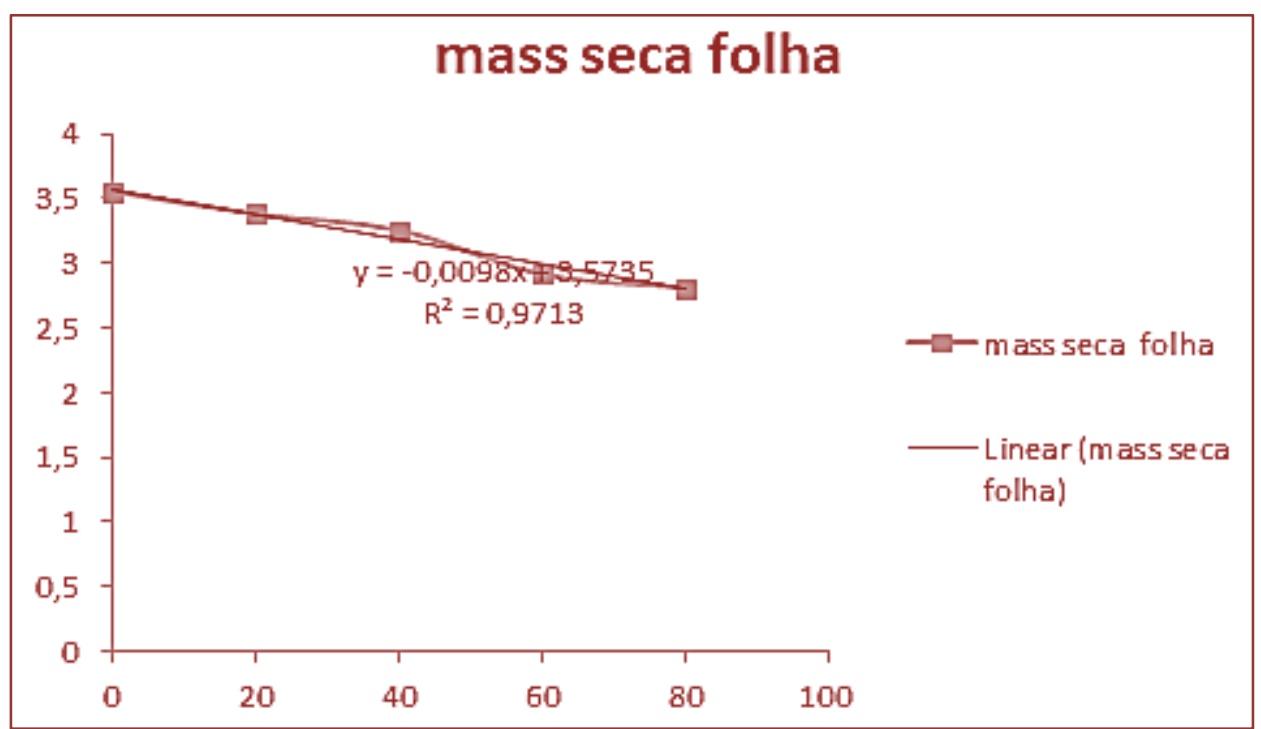


Figura 2. Massa seca do caule de manjericão após 60 dias de cultivo. Os valores indicam médias de quatro repetições e os respectivos tratamentos (níveis crescentes de Nacl 0,20,40,60,80 mM).

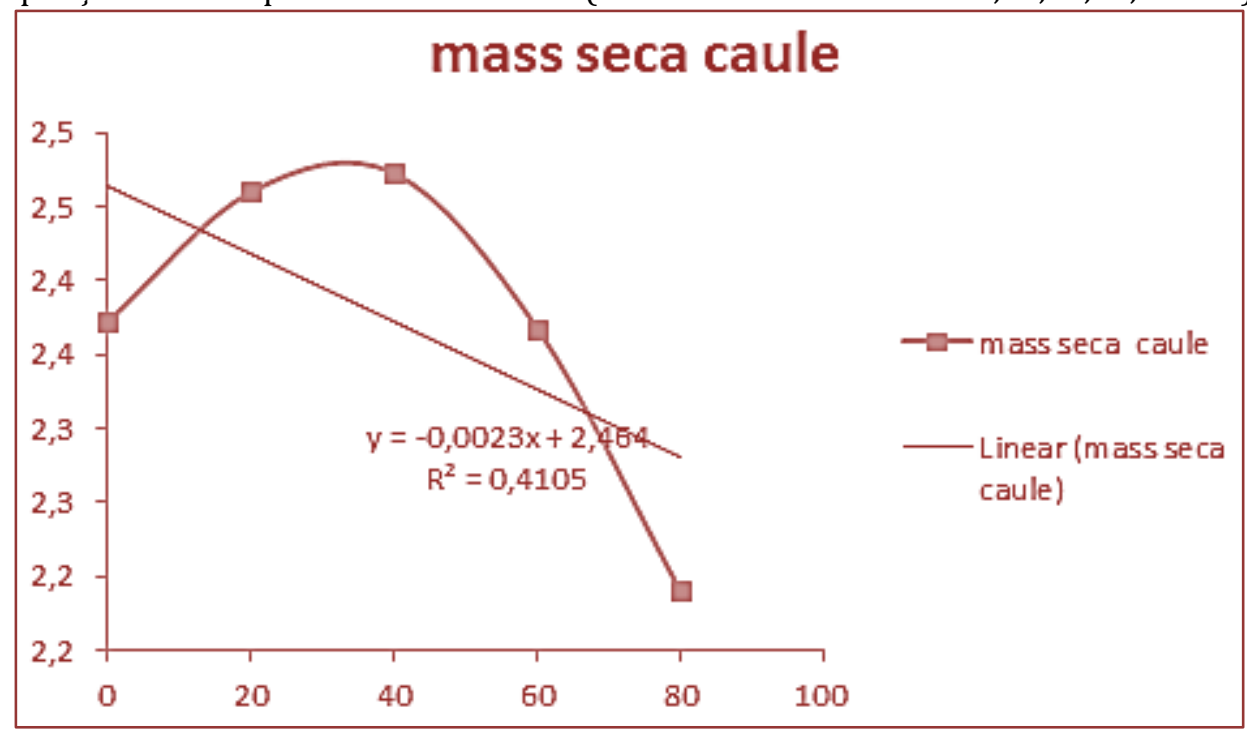

Figura 3. Massa seca da raiz de manjericão após 60 dias de cultivo. Os valores indicam médias de quatro repetições e os respectivos tratamentos (níveis crescentes de Nacl 0,20,40,60,80 mM).

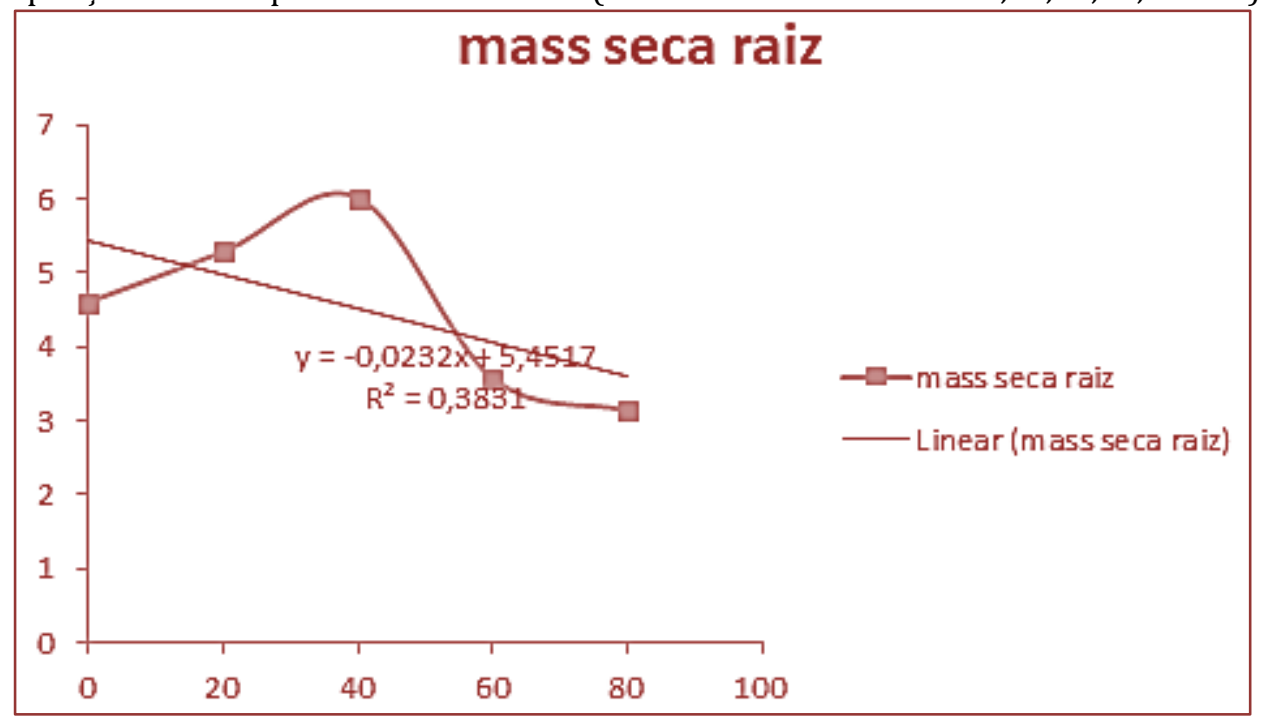

\subsection{ALTURA, DIÂMETRO DO CAULE VOLUME DE RAIZ}

A altura diminuiu $0,07625 \mathrm{~cm}$ por incremento de $\mathrm{mM} \mathrm{NaCl}$, variando de $51,5 \mathrm{~cm}$ no controle para $45,4 \mathrm{~cm}$ no tratamento de $80 \mathrm{mM}$.Além de sistemas hidropônicos como o realizado por L. S. Alves et al(2013) e por Menezes(2017), vários outros estudos apontam para a redução na altura das plantas, sob estresse salino, em variedades de manjericão quando cultivado em solo como relatado por Silva(2012).

0 diâmetro do caule apresentou redução de $51 \mathrm{~mm}$ para $47 \mathrm{~mm}$, reduzindo $0,05 \mathrm{~mm}$ por incremento de mM Nacl. 0 diâmetro do caule é uma variável importante, pois é responsável pelo suporte das plantas e se muito fino pode causar o tombamento da planta. 


\subsection{TEOR DE CLOROFILA E ÁREA FOLIAR}

Os teores de clorofila a e b apresentaram resultados semelhantes mediante o aumento das doses Nacl nos respectivos tratamentos, ambos não apresentaram um comportamento linear crescente. Para clorofila a não houve diferença quando comparados os valores correspondentes aos tratamentos máximo e mínimo, porém a maior dose foi responsável por um aumento significativo no teor do pigmento e no tratamento $60 \mathrm{mM}$ ocorreu uma significativa redução, indicando que esta dose não é suficiente para causar aumento no teor de clorofila. A concentração de clorofila b reduziu nas doses intermediárias (40 e $60 \mathrm{mM})$ e aumentou na dose máxima. Para ambas variáveis, não houve incremento nos teores quando comparados o tratamento controle e o máximo incremento de $\mathrm{mM} \mathrm{NaCl}$ em solução nutritiva. A área foliar apresentou um decréscimo de $8 \mathrm{~cm}^{-2}$, comparando-se as doses mínima e máxima. 0 aumento da concentração de clorofila por unidade de área evidencia-se nesse estudo, pois as doses que resultaram em um aumento no teor de clorofila correspondem a medidas de área foliar menores. Conforme Cosgrove (1993) o estresse salino decresce o crescimento foliar, devido a redução na elongação das células consequência da baixa absorção de água ocasionada pelo baixo potencial hídrico nas raízes , o que reduz a elongação foliar. 0 aumento da concentração de clorofila por unidade de área foliar pode estar associado a alterações morfológicas na folha em resposta a estresses ambientais, como a um aumento da espessura da folha devido redução da área foliar, ocasionada por salinidade. (PRESOTTO, et al.2013).

Figura 4. Clorofila b de plantas de manjericão após 50 dias de cultivo em solução nutritiva contendo níveis crescentes de Nacl. Os valores indicam médias de quatro repetições e os respectivos tratamentos $(0,20,40$ e $60 \mathrm{mMl}$ )

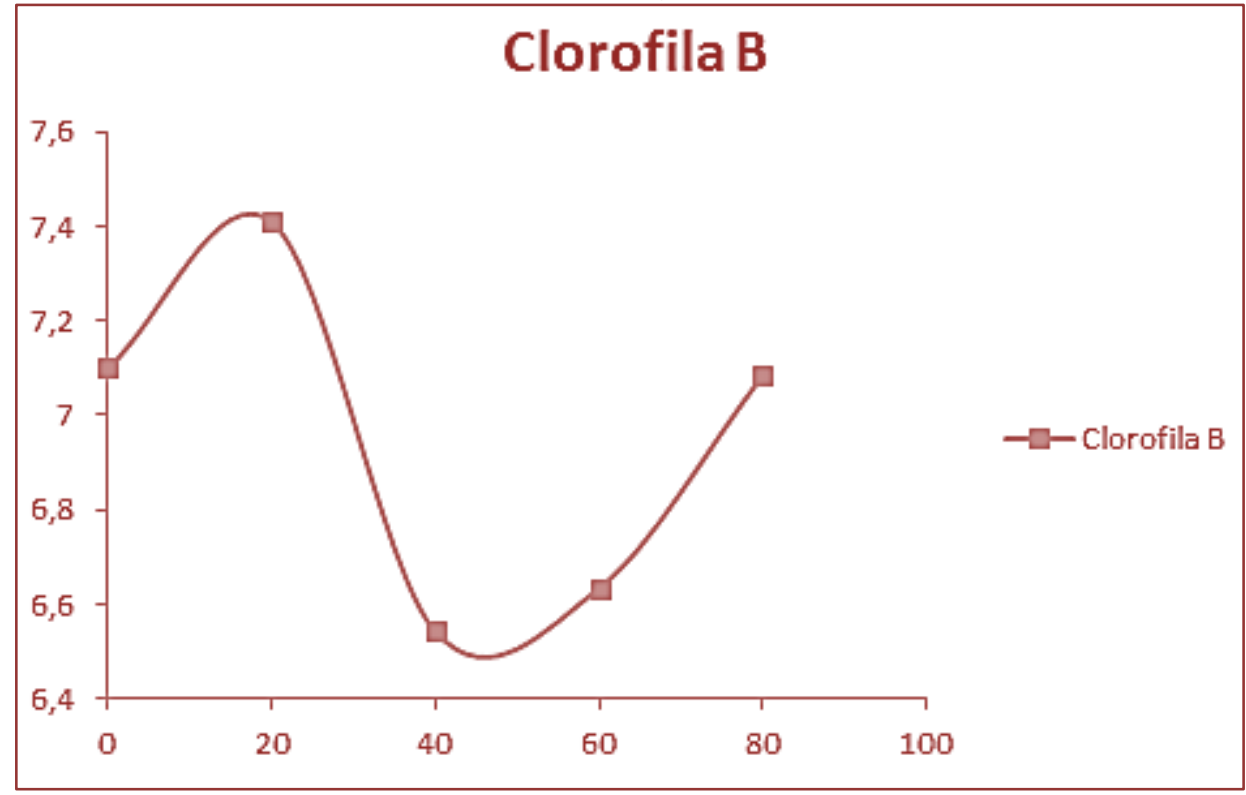


Figura 5. Área foliar de plantas de manjericão após 50 dias de cultivo em solução nutritiva contendo níveis crescentes de Nacl. Os valores indicam médias de quatro repetições e os respectivos tratamentos $(0,20,40$ e $60 \mathrm{mMl}$ )

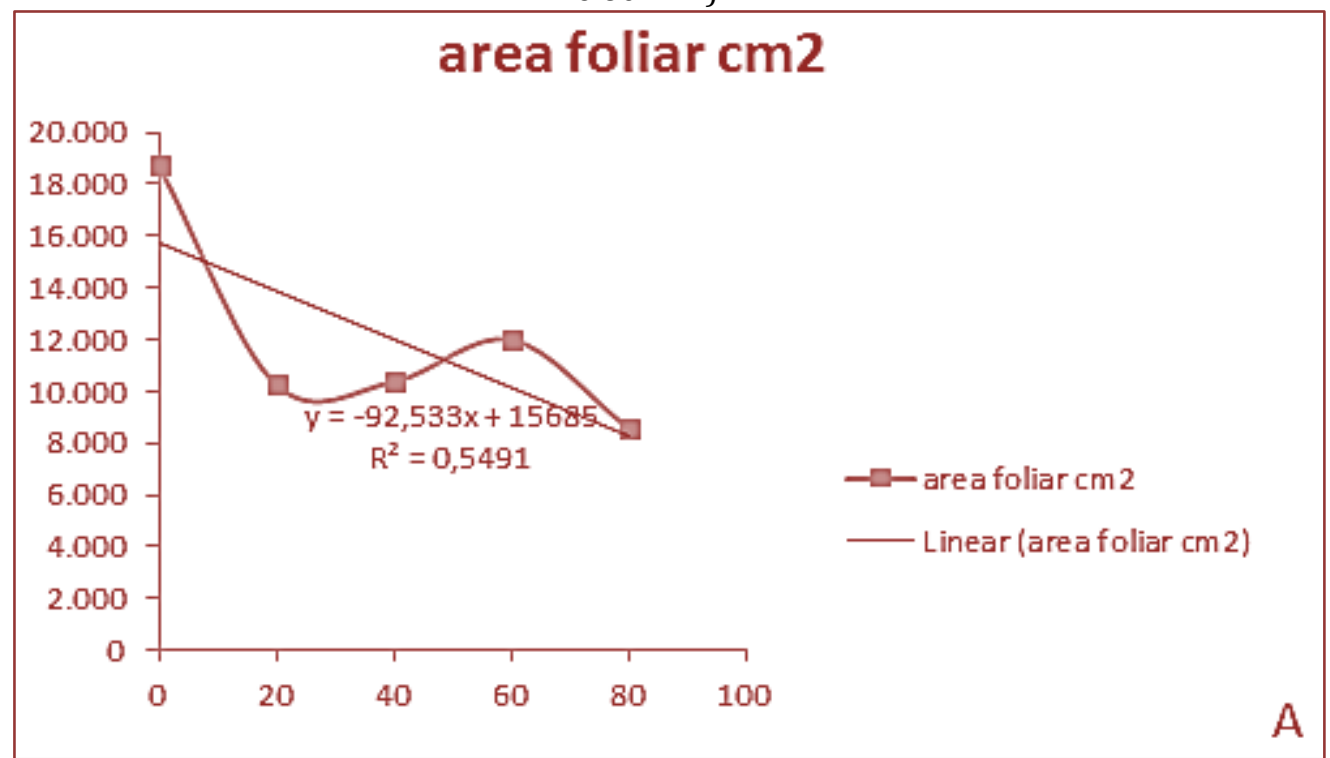

Figura 5. Clorofila a de plantas de manjericão após 50 dias de cultivo em solução nutritiva contendo níveis crescentes de Nacl. Os valores indicam médias de quatro repetições e os respectivos tratamentos $(0,20,40$ e $60 \mathrm{mMl}$ )

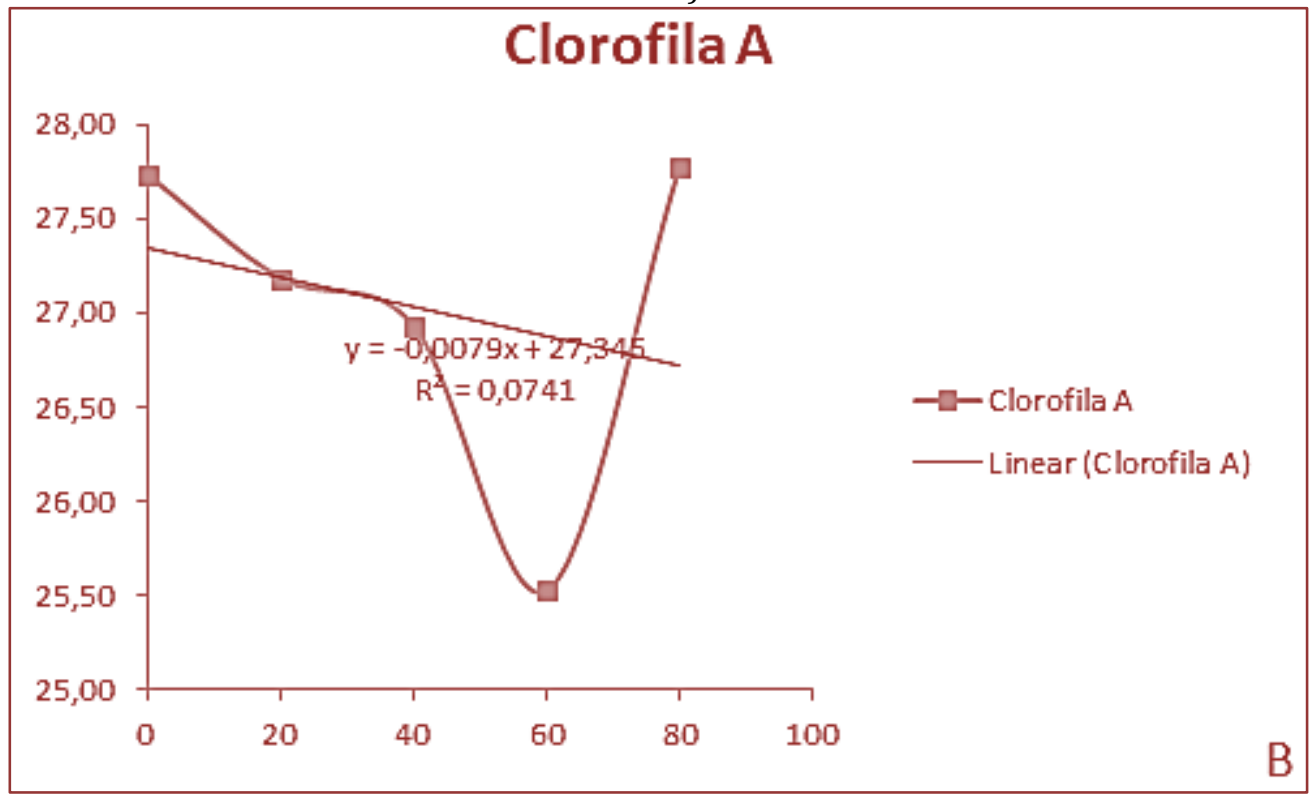




\section{TEOR DE ÓLEO ESSENCIAL}

Tabela 1. 0 teor de óleo essencial plantas de Ocimum basilicum L. cultivadas e submetidas a vários níveis de salinidade. Cruz das Almas, BA, 2018

\begin{tabular}{|c|c|}
\hline Tratamentos & Teor (óleo) \\
\hline T0 & $0,50 \mathrm{a}$ \\
\hline T20 & $0,52 \mathrm{a}$ \\
\hline T40 & $0,53 \mathrm{a}$ \\
\hline T60 & $0,57 \mathrm{~d}$ \\
\hline T80 & $0,70 \mathrm{e}$ \\
\hline \multicolumn{2}{|c|}{$\mathrm{CV}(\%)=12,72$} \\
\hline
\end{tabular}

*Médias seguidas por letras distintas na coluna diferem estatisticamente entre si pelo teste Tukey $(\mathrm{P}=0,05) .1 \% 5 \%$

Como descrito anteriormente, os óleos essenciais são produtos do metabolismo secundário das plantas e representam uma comunicação química com o ambiente externo, por isso fatores ambientais influenciam na síntese destes metabólitos. 0 aumento no teor de óleo pode ser diretamente relacionada ao estresse salino pois estudos como de Gobbo Neto e Lopes(2007) tem relacionado os óleos essenciais com a produção de metabólitos secundários como uma resposta da planta a algumas condições como de temperatura e índice pluviométrico que desfavorecem o crescimento. A produção de óleo essencial pelas plantas de manjericão é favorecida por condições de salinidade, como indicado no presente estudo. 0 trata.

Os dados podem estar diretamente relacionados com o substrato utilizado na condução do experimento, que pode ter favorecido a imobilização do sódio fator que reduz o efeito da salinidade na parte aérea e aumenta na raiz como verificado nos resultados de produção de fitomassa pois de acordo com Epstein e Bloom (2006) as raízes são órgãos em contato mais estreito com o ambiente nutricional da planta e por isso elas são especialmente propensas a serem afetadas por este ambiente.

O contrário do que foi verificado para clorofila, pois o aumento nos teores dessa variável relacionam-se com diferença de potencial hídrico existente entre a raiz e a parte devido a salinidade ,que ocasiona redução na absorção de água e diminui a elongação celular e por consequência a área foliar , assim aumentando as concentrações de clorofila no interior da células foliares.

\section{CONCLUSÕES}

A salinidade reduz a massa seca da planta de manjericão. 0 teor de clorofila e de óleo essencial da planta responde de forma positiva para o incremento de salinidade na solução nutritiva.

\section{REFERÊNCIAS}

[1] CALVACANTE, L.F., et al. Fontes e níveis da salinidade da água na formação de mudas de mamoeiro cv. Sunrise solo. Semina: Ciências Agrárias, Londrina, v. 31, suplemento 1, p. 1281-1290, 2010.

[2] COSGROVE, D.J. Water uptake by growing cells: an assessment of the controlling roles of wall relaxation, solute uptake and hydraulic conductance. International Journal of Plant Science, v. 154, p. 10-21, 1993.

[3] FARIAS, S. G. G. et. al. Estresse salino no crescimento inicial e nutrição mineral de Gliricídia (Gliricídia sepium (Jacq.) Kunt ex Steud) em solução nutritiva. Revista Brasileira de Ciência do Solo, v. 33, p. 1499-1505, 2009.

[4] FERNANDES,R.A. Crescimento de cultivares de manjericão (Ocimum basilicum L.) cultivadas em vasos.2014.Tese(Doutorado em Fitotecnia).Universidade Federal de Viçosa. Viçosa.

[5] FERREIRA, G.R., et al . Distribuição da matéria seca e composição química das raízes, caule e folhas de goiabeira submetida a estresse salino. Pesquisa agropecuária Brasileira , Brasília, v. 36, n. 1, p. 79-88, jan. 2001.

[6] FIOREZE, A.P., et al. A questão da água no nordeste. Brasília: Centro de Gestão e Estudos Estratégicos, 2012.

[7] L. S. Alves, et al. Crescimento, produção e eficiência do uso da água do manjericão sob estresse salino. IV INOVAGRI International Meeting, 2017. 
[8] MENEZES, R,V. Tolerância á salinidade em manjericão sob cultivo hidropônico.2017.111f.Tese(Doutorado em Engenharia Agrícola: Área de concentração agricultura irrigada e recursos hídricos )-Universidade Federal do Recôncavo da Bahia, Cruz das Almas,2017.

[9] NETO, G.L,LOPES, P, N. Plantas medicinais: fatores de influência no conteúdo de metabólitos secundários. Química nova, Ribeirão Preto, Vol. 30, No. 2, 374-381, 2007.

[10] Presotto,R.A, et al . Influência da salinidade no teor e índice de clorofila em três variedades de mamoneira. Congresso brasileiro de ciência do solo .4,p, 2013.

[11] SILVA, C. M. F. Avaliação de diferentes substratos na produção de biomassa e teor de óleo essencial de manjericão (Ocimum basilicum L.). 2012. 65 f. Dissertação (Mestrado em Ciências Agrárias: Área de Concentração em Fitotecnia) - Universidade Federal do Recôncavo da Bahia, Cruz das Almas, 2012.

[12] SILVA, F.A.M., et al. Efeito do estresse salino sobre a nutrição mineral e o crescimento de mudas de aroeira (Myracrodruon urundeuva) cultivadas em solução nutritiva. Cerne, V.6, N.1, P.052-059, 2000

[13] Vieira, R.F. \& Simon, J.E. Econ Bot (2000) 54: 207. https://doi.org/10.1007/BF02907824.

[14] ZENEBON, O.; PASCUET, N. S.; TIGLEA, P. Métodos físico-químicos para análise de alimentos. 4. ed.; versão digital. Brasília, DF: Ministério da Saúde, 2008, 1020 p. 


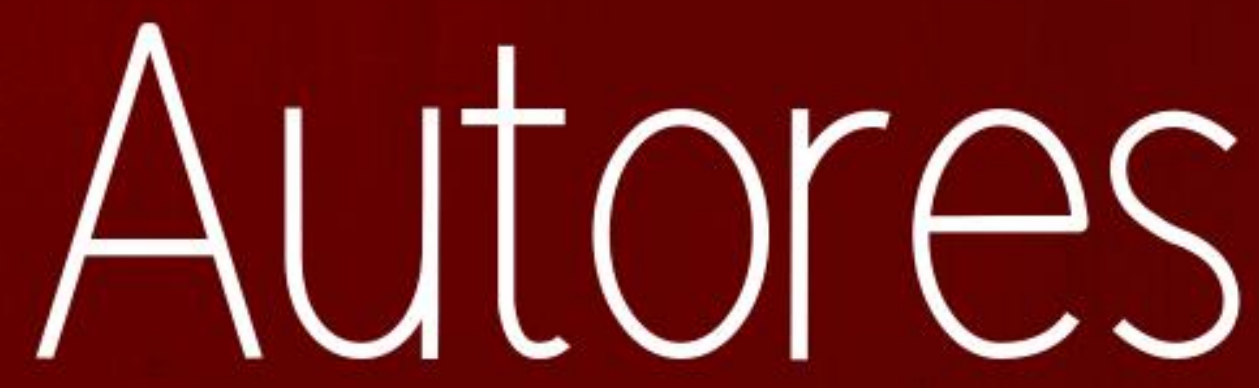




\section{EZEQUIEL REDIN (ORGANIZADOR)}

Professor Adjunto do Instituto de Ciências Agrárias da Universidade Federal dos Vales do Jequitinhonha e Mucuri (UFVJM) e Vice-Coordenador do Programa de Pós-Graduação Interdisciplinar em Estudos Rurais). Membro da Academia Centro Serra de Letras, ocupando a cadeira n. 21. Membro dos Comitês de avaliação da FAPERGS/RS, FAPESC/SC e FAPITEC/SE. Editor do Periódico Extensão Rural (Santa Maria). Tesoureiro da Associação Riograndense dos Tecnólogos (ARTECNOL). Formado na licenciatura do Programa Especial de Graduação de Formação Pedagógica de Professores (PEG/UFSM - 2012-2013). Formado no curso de Filosofia Licenciatura (UFSM - 2016-2019). Formado no Mestrado em Extensão Rural (2009-2011). Formado na Pós-graduação em Gestão Pública Municipal (2010-2011). Formado na Pós-graduação em Tecnologias de Informação e Comunicação aplicadas à Educação (UFSM - 2013-2014). Formado na Pós-graduação em Ensino de Sociologia no Ensino Médio (2014-2015). Formado na Pósgraduação em Ensino de Filosofia no Ensino Médio (2017-2018). Doutorado em Extensão Rural pelo Programa de Pós-graduação em Extensão Rural (2011-2015). Foi o criador da Pós-graduação Lato Sensu e Coordenador do Curso de Pós-graduação em Agronegócios da Faculdade Metodista de Santa Maria (2017-2018). Foi Coordenador do Curso de Administração (2018-2018). Foi Coordenador do Curso de Ciências Contábeis (2018-2018). Foi Assessor da Pós-graduação da Faculdade Metodista de Santa Maria (2017-2018).

\section{ADRIANA DIAS CARDOSO}

Possui graduação e mestrado em Agronomia pela Universidade Estadual do Sudoeste da Bahia (2004), e doutorado em Agronomia (Fitotecnia) pela Universidade Federal de Lavras, atuando principalmente nos seguintes temas: produção vegetal, olericultura, mandiocultura, nutrição de plantas e pós-colheita. Atualmente, leciona as disciplinas Melhoramento Vegetal e Fruticultura na UESB, com experiência na área de Fitotecnia.

\section{ALAN BERNARD OLIVEIRA DE SOUSA}

Engenheiro Agrônomo; Doutor em Ciências; Professor da Universidade Federal do Ceará - UFC, Fortaleza, Ceará.

\section{ALCEBÍADES REBOUÇAS SÃO JOSÉ}

Possui graduação em Agronomia pela Universidade Estadual do Sudoeste da Bahia -UESB, Mestrado em Fitotecnia pela Universidade de São Paulo-ESALQ e Doutorado em Agronomia (Produção Vegetal) pela Universidade Estadual Paulista Júlio de Mesquita Filho -Jaboticabal-SP. Pós-Doutorado, UNESP/FCA/Botucatu-SP no Departamento de Agricultura na área de Matologia. Atualmente é Professor Pleno da Universidade Estadual do Sudoeste da Bahia -UESB. Foi Diretor do Departamento de Fitotecnia e Zootecnia da UESB. Foi Coordenador do Programa de PósGraduação em Agronomia- Fitotecnia da UESB. Tem experiência na área de Agronomia, com ênfase em Manejo de Plantas Daninhas, Herbicidas, Produção de mudas, Floricultura e Paisagismo.

\section{ALDENIR FEITOSA DOS SANTOS}

Possui mestrado em Química e Biotecnologia pela Universidade Federal de Alagoas (1997) e doutorado em Química e Biotecnologia pela Universidade Federal de Alagoas (2005). Atualmente é coordenadora stricto sensu da coordenação de pesquisa e pós-graduação do Centro Universitário CESMAC. Também atua como professora e pesquisadora no Curso de Mestrado Profissional de Pesquisa em Saúde e no Curso de Medicina. É professora titular e pesquisadora do Curso de Licenciatura em Química da Universidade Estadual de Alagoas onde também coordena o Núcleo de química do PIBID/UNEAL . Tem experiência na área de fitoterapia e fitoquímica, com ênfase em química de compostos bioativos, atuando principalmente nos seguintes temas: atividade antioxidante, cicatrizante, moluscicida, cercaricida, antiesquistossomótica e hipoglicemiante de espécies vegetais, incluindo também seus resíduos. A pesquisa por composto naturais bioativos é sua principal área de atuação e dentro desta linha fez o pós-doutorado no Instituto de Química e 
Biotecnologia da UFAL, Laboratório de Pesquisa em Recursos Naturais - LPqRN, na área de produtos naturais com ação anti-HIV e antioxidante.

\section{ALEJANDRO ECHEVERRY TORO}

Bacharel em Engenharia agronomica pela Universidade de Caldas (Colombia) (2013-2019), Auxiliar de investigação e evaluador de rendimiento en campo no laboratorio de fitopatología da Universidade de Caldas (2016 - 2017) "Encuentro local de semilleros de investigación nodo caldas" - apresentação de poster na Universidade Catolica Luis Amigo ( Maio de 2018) profundização em nutrição e biología do solo (2017) (Universidade de Caldas-Colombia)

\section{ALESSANDRA SILVA BATISTA}

Engenheira Florestal pela Universidade Federal do Oeste do Pará (UFOPA), com pesquisas na área de Tecnologia da Madeira. Atualmente, é mestranda no Programa de Pós-graduação em Recursos Florestais da ESALQ/USP, com linha de pesquisas em aplicações de materiais lignocelulósicos da Amazônia, para produção de eco painéis visando diferentes usos.

\section{ALLAN HEMERSON DE MOURA}

Possui curso técnico em Agropecuária pelo Instituto Federal de Alagoas (IFAL), Engenheiro agrônomo formado pela Universidade Federal de Alagoas (UFAL). Atualmente mestrando em agronomia, na área de Produção Vegetal pela Universidade Federal de Alagoas (UFAL).

\section{AMANDA LIMA CUNHA}

Graduada em Licenciatura em Química pela Universidade Estadual de Alagoas - UNEAL, com experiência na área de pesquisa de Ensino de química e experimentação, atua na área de pesquisa de produtos naturais com ênfase no estudo de análise de atividade antioxidante e compostos bioativos.Mestrado Agricultura e Ambiente (PPGAA) - UFAL, com pesquisa intitulada "Caracterização química e fisiológica da espécie Raphanus sativus L. sob efeito de adubação orgânica, mineral e estresse hídrico. Integrante do Grupo de Pesquisa em Química - GRUPEQ.

\section{ANA IZABELLA FREIRE}

Possui graduação em Agronomia (2013) e mestrado em Genética e Melhoramento de Plantas pela Universidade Federal de Lavras - UFLA (2015). Doutora em Fitotecnia pela Universidade Federal de Viçosa - UFV (2019) Estagiária na empresa DUPONT DO BRASIL S.A - DIVISÃO PIONEER SEMENTES, atuando com produção de sementes de milho (2013). Tem experiência com ênfase em Produção de Sementes e Genética e Melhoramento de Plantas. Estágios de docência durante o mestrado e doutorado em disciplinas relacionadas a diversas áreas. Licenciada em Letras Português/Inglês pela Faculdade Alfa América. Docente no Centro Universitário UNA durante 2 semestres.

\section{ANA PAULA BRITO DE SOUZA}

Graduanda do curso de Engenharia Florestal pela Universidade Estadual da Região Tocantina do Maranhão - UEMASUL

\section{ANTONIO ANDRÉ CAVALCANTE NUNES}

Técnico em Apicultura pelo Instituto Federal de Educação, Ciência e Tecnologia do Rio Grande do Norte - IFRN. Graduando em Farmácia pela Universidade Federal do Rio Grande do Norte - UFRN. 


\section{ARIANA MOTA PEREIRA}

Engenheira agrônoma graduada pela Universidade Federal de Viçosa - MG, mestre em Fisiologia Vegetal pela Universidade Federal de Viçosa - MG, doutora em Fitotecnia pela Universidade Federal de Viçosa - MG e Pós-doutora em Fitotecnia pela Universidade Federal de Viçosa - MG com pesquisas com enfase em fisiologia vegetal, floricultura e horticultura.

\section{BRUNO MONTEIRO BALBONI}

Bacharel em Ciências Biológicas e Engenharia Florestal, ambos pela Universidade de São Paulo, com ênfase em Anatomia da Madeira e Propriedades Mecânicas da Madeira. Atualmente, é doutorando em Recursos Florestais na Universidade de São Paulo, onde desenvolve tese sobre Madeira Laminada Colada com Florestas Jovens de Eucalipto. Possui experiência em pesquisa com Tecnologia da Madeira na Amazônia, Austrália e Chile, e suas áreas de interesse são: produtos engenheirados de madeira, valorização de resíduos da indústria madeireira, florestas jovens, Eucalyptus.

\section{CEZAR DIAS CARDOSO JUNIOR}

Engenheiro Florestal, com Especialização em Geoprocessamento e Georreferenciamento, e Mestrando em Ciências Ambientais e Florestais na Universidade Federal Rural do Rio de Janeiro UFRRJ.

\section{CICERO TEIXEIRA SILVA COSTA}

Possui graduação em agronomia pela Universidade Federal de Alagoas (UFAL), mestrado em produção vegetal pela Universidade Federal de Alagoas (UFAL) e doutorado em irrigação e drenagem pela Universidade Estadual Paulista (UNESP). Atualmente é professor do Instituto Federal do Mato Grosso do Sul - Campus Navírai.

\section{DIEGO BRANDÃO}

Agrônomo; Doutor em Ciências, Departamento de Engenharia de Biossistemas, Escola Superior de Agricultura Luiz de Queiroz / Universidade de São Paulo, Piracicaba, SP.

\section{DIEGO LIMA AGUIAR}

Bacharel em Ciências Agrárias e em Engenharia Florestal pela Universidade Federal do Oeste do Pará e mestre em Recursos Florestais pela ESALQ/USP. Trabalhou com pesquisas dendrocronológicas e atualmente está desenvolvendo pesquisas na área de painéis de madeira.

\section{EDMILSON CESAR BORTOLETTO}

Professor Adjunto do Departamento de Engenharia Agrícola da Universidade Estadual de Maringá (UEM). Tem experiência em recursos hídricos, tratamento de efluentes, controle de poluição e utilização de águas residuárias na agricultura. Possui graduação em Engenharia Química pela UEM, com Mestrado e Doutorado em Engenharia Química (UEM).

\section{ERICA PRIULLI}

Nutricionista, Administradora de Empresas, especialista em Nutrição Clínica, tem experiência em gestão de Unidades de Alimentação e Nutrição de grande porte. Possui mestrado em Ciência e Tecnologia em Alimentos pela Universidade Federal do Tocantins (2020) quando atuou em pesquisa com frutos do cerrado e soja. 


\section{EUDOCIA CARLA DE ARAÚJO}

Mestre em Ciência e Tecnologia Ambiental pela Universidade Estadual da Paraiba, atuando nas áreas de Microbiologia, Bioquimica e Tratamento Biológico de águas Residuárias. Bacharela em Engenharia de Biotecnologia e Bioprocessos pela Universidade Federal de Campina Grande.

\section{FÁBIO EDUARDO NEMET}

Possui graduação em Engenharia de Produção e Licenciatura em Matemática. Especialista em Gestão de Logística e Docência do Ensino Superior. Atualmente atua como coordenador de PósGraduação da Faculdade Unopar de Palmas-TO.

\section{FABRÍCIO VIEIRA DUTRA}

Engenheiro Agrônomo, mestre em Agronomia pela Universidade Estadual do Sudoeste da Bahia. Participou do programa de Iniciação Científica no laboratório de Melhoramento e Produção Vegetal, com pesquisas relacionadas a cultura da Mandioca, pós-colheita, amido, variedades. Atuou como Monitor da disciplina Tecnologia e Produção de Sementes. Atualmente é doutorando do programa de pós-graduação em Agronomia da UESB, com a linha de pesquisa manejo e propagação de culturas.

\section{FELIPE DE SOUZA SILVA}

Engenheiro Agrícola pela Universidade Estadual de Maringá (UEM)

\section{FILIPE BITTENCOURT MACHADO DE SOUZA}

Graduado em Engenharia agronômica pela Universidade Federal de Lavras-MG no ano de 2009, mestre no programa de fitotecnia pela Universidade Federal de Lavras-MG no ano de 2012, na sub área de Fruticultura de clima subtropical sob orientação do prof. Dr. Rafael Pio e co-orientação do pesquisador Dr. Ângelo Alvarenga Albérico pela Universidade Federal de Lavras-MG. em Fitotecnia/Agronomia (2010-2012) pela Universidade Federal de Lavras (UFLA) sob a orientação do Prof. Dr. Rafael Pio, onde tive a oportunidade de pesquisar frutíferas de clima temperado em região subtropical. Posteriormente, iniciei o doutorado em Fitotecnia/Agronomia (2012-2016) pela Universidade Federal de Lavras (UFLA) sob orientação do Prof. Dr. Rafael Pio, durante este período realizei parte do doutorado na Clemson University (2014) sob orientação do PhD Gregory Reighard. Durante o doutorado também ministrei aulas para discentes da graduação com as matérias de Fruticultura Geral (GAG 108), Abacateiro e Goiabeira (GAG 110), Bananeira, Abacaxizeiro e Mangueira (GAG 115) e Videira, Pessegueiro e Figueira (GAG 143). Sucessivamente, continuei o aperfeiçoamento acadêmico por meio de pós-doutorado pelo departamento de Fitopatologia (2016) no laboratório de Microscopia Eletrônica pela Universidade Federal de Lavras (UFLA) sob orientação do Prof. Dr. Eduardo Alves, onde desempenhei e desenvolvi estudos voltados para anatomia, ecologia e fisiologia. Atualmente, faço pós-doutorado no programa de Desenvolvimento Sustentável pelo Instituto Tecnológico Vale (ITV) sob orientação do Prof. Dr. Antônio Furtini, neste contexto, realizo projetos voltados para a recuperação de áreas degradas pela mineração em Carajás (PA). Atualmente é professor titular do curso de agronomia do Centro Universitário Tocantinense Presidente Antônio Carlos (UNITPAC/Araguaína), onde ministra as disciplinas Fisiologia Vegetal, Gênese, Morfologia e Classificação do Solo e Zootecnia Geral.

\section{GABRIELA LEITE SILVA}

Graduanda de Engenharia Agronômica, pela Universidade Estadual do Sudoeste da Bahia, Campus Vitória da Conquista. Atualmente é Bolsista do Programa de Iniciação Científica pelo CNPq (Conselho Nacional de Desenvolvimento Científico e Tecnológico) no Laboratório de Química II/Bioquímica. Atuou como Bolsista no Programa de Iniciação Científica pela FAPESB (Fundação de Amparo à Pesquisa do Estado da Bahia) no Laboratório de Biotecnologia, onde desenvolveu pesquisas nos seguintes temas: eucalyptus spp, brs novaera, brachiaria, controle químico e infestação comunitária. 


\section{INGRID SOFIA VIEIRA DE MELO}

Possui graduação em nutrição pela Universidade Federal de Alagoas (2009) e graduação em Curso superior Tecnológico em alimentos pelo Instituto Federal de Educação Ciência e Tecnologia de Alagoas (IFAL/ 2007). Mestre em nutrição pela Universidade Federal de Alagoas, e Doutora em Biotecnologia pela Rede Nordeste de Biotecnologia (CAPES 5), área de concentração saúde. Atualmente é professora efetiva do IFAL, campus Satuba, em regime de dedicação exclusiva e pesquisadora bolsista de produtividade PQ-A pela mesma instituição. Membro do Comitê de Ética em Pesquisa envolvendo Seres humanos do Ifal (CEPSH).

\section{ISABELLA DA ROCHA SILVA}

Graduada em Engenharia de Biotecnologia e Bioprocessos, no Centro de Desenvolvimento Sustentável do Semiárido, Universidade Federal de Campina Grande (UFCG). Graduanda em Matemática, Universidade Estadual da Paraíba (UEPB).

\section{JEFERSON MIGUEL DIAS SANTOS}

Engenheiro agrônomo formado pela Universidade Federal de Alagoas (UFAL) com mestrado em Engenharia Agrícola pela Universidade Federal de Campina Grande (UFCG).

\section{JOÃO VICTOR LAURINDO DOS SANTOS}

Técnico em Agroindústria pelo IFAL. Atualmente é discente do curso de Nutrição da Faculdade Estácio de Alagoas.

\section{JOÃO VITOR COSTA DE ALMEIDA}

Engenheiro Agrícola pela Universidade Estadual de Maringá (UEM)

\section{JOHNATHAN ERICK FERNANDES GAMELEIRA}

Técnico em Apicultura pelo Instituto Federal de Educação, Ciência e Tecnologia do Rio Grande do Norte - IFRN.

\section{JONAS JULIERMERSON SILVA OTAVIANO}

Mestrado em andamento no curso de Engenharia Geológica pela Universidade de Aveiro Portugal; Graduado em Engenharia Florestal pela Universidade Estadual da Região Tocantina do Maranhão - UEMASUL; Foi bolsista do programa de estágio internacional pela Fundação de Amparo à Pesquisa e ao Desenvolvimento Científico e Tecnológico do Maranhão - FAPEMA em 2019; bolsista voluntário do programa de extensão PIBEXT/UEMASUL no período 2017/2018; Bolsista de apoio técnico e institucional BATI/UEMASUL na modalidade graduando entre 2017/2018. Bolsista de iniciação científica PIBIC/UEMA no período 2014/2015; Bolsista voluntário de iniciação científica PIBIC/UEMA entre 2013/2014.

\section{JORGE DINIZ DE OLIVEIRA}

Graduação em Química Industrial pela UFMA e Curso Emergencial de Licenciatura Plena Esquema I pelo CESI/UEMA. Mestrado em Química Inorgânica pela UFC e Doutorado em Química pela UNESPAraraquara-SP. Professor adjunto IV da UEMASUL-Imperatriz-MA lecionando Química dos Compostos de Coordenação e Química Ambiental. Coordenador do Laboratório de Química Ambiental da UEMASUL. Atua no Programa de Pós-Graduação Mestrado Agricultura e Ambiente da UEMA lecionando Química Agroambiental. Têm experiência na área de Química com ênfase em Química de Coordenação e Química Ambiental atuando nos seguintes temas: Metais Potencialmente Tóxicos em Ecossistemas Aquático e Terrestres, Fitorremediação de Metais em Solos Antropizados. 


\section{JOSE JAHIR MORALES MURILLO}

Técnico em administração de empresas pecuárias pelo Servicio Nacional de Aprendizaje (SENAColombia) (2010-2011) Profundización en sistemas de producción de cultivos de clima calidotemplado-frio granja, Montelindo sector Malteria - Manizales y granja tesorito SantaguedaCaldas(universidad de caldas) 2018 - periodo 1 Bacharel em Engenharia agronomica pela Universidade de Caldas (Colombia) (2013-2019), Auxiliar de investigação e evaluador de rendimiento en campo no laboratorio de fitopatología da Universidade de Caldas (2016 - 2017) "Encuentro local de semilleros de investigación nodo caldas" - apresentação de poster na Universidade Catolica Luis Amigo ( Maio de 2018) Estagio no laboratorio Interação inseto- planta, Departamento de Entomología da Universidade Federal de Viçosa, Estágio no laboratorio de acarologia, Departamento de Entomologia da Universidade Federal de Viçosa Mestrando em Entomologia na Universidade Federal de Viçosa

\section{JOSE RENATO GUIMARAES}

Doutorando em Engenharia Química pela Universidade Federal de São Carlos (UFSCar) e Mestre em Engenharia Química pela mesma instituição (UFSCar, 2019). Graduado em Engenharia de Biotecnologia e Bioprocessos pela Universidade Federal de Campina Grande (UFCG, 2016). Tem experiência nas áreas de prospecção e produção de metabólitos (biossufactante, quitinase e quitosanase) a partir de fungos filamentosos do semiárido brasileiro e na produção de bioetanol via co-cultivo de fungos (projeto submetido para depósito). Atualmente desenvolve pesquisa na área de Engenharia Bioquímica, com ênfase em imobilização de enzimas de interesse industrial para síntese de produtos com valor agregado.

\section{KARLA T. M. GOLLNER-REIS}

Professora e pesquisadora, aposentada, do Instituto Federal de Alagoas.

\section{LEKSON RODRIGUES SANTOS}

Engenheiro agrônomo formado pela Universidade Federal de Alagoas (UFAL) com mestrado em Agronomia - Produção Vegetal (UFAL).

\section{LUANA DA SILVA GUEDES}

Graduanda em Engenharia Florestal pela Universidade Federal do Recôncavo da Bahia. Tem experiência na área de Recursos Florestais e Engenharia Florestal, com ênfase em Silvicultura.

\section{LUANA NASCIMENTO DA SILVA}

Graduanda em Engenharia Agronômica pela Universidade Federal do Recôncavo da Bahia.Tem experiência na áreas de Fitopatologia, Solos e Melhoramento Vegetal.

\section{LUCAS RODOLFO INÁCIO DA SILVA}

Mestre em Engenharia Química pela Universidade Federal de Santa Catarina (UFSC), Graduado em Engenharia de Biotecnologia e Bioprocessos pela Universidade Federal de Campina Grande (UFCG/CDSA). Tem experiência em Bioprocessos, Biotecnologia, Microbiologia Industrial, Fitossanidade, Gestão da Qualidade e Enzimologia. Atua principalmente nos seguintes temas: gestão da qualidade, controle alternativo de doenças em cultivos, produção de celulases a partir de resíduos agroindustriais, prospecção de enzimas amilolíticas, valorização de biomassas, fermentação em estado sólido e microbiologia industrial. 


\section{LUCIETA GUERREIRO MARTORANO}

Concluiu o doutorado na Universidade Federal do Rio Grande do Sul e mestrado na ESALQ/USP em Piracicaba. Trabalha na Embrapa há 30 anos, onde tem desenvolvido atividades como liderança de projetos de pesquisa em âmbito nacional e internacional, Tem colaborando como professora permanente de programas de pós-graduação. Suas parcerias científicas vêm fortalecendo sua produção científica, inclusive sendo uma das pesquisadoras com bolsa de produtividade do CNPq.

\section{LUISA VÁSQUEZ RAMÍREZ}

Maestría/Magister Universidade de Caldas (Colombia) Mestrado em Fitopatología Enerode2015 - de EFECTO DE BACTERIAS PROMOTORAS DE CRECIMIENTO VEGETAL EN EL CONTROL DE LA MARCHITEZ VASCULAR (Fusarium oxysporum f.sp. lycopersici) DEL TOMATE (Solanum lycopersicum L.) Bacharel em Engenharia agronomica pela Universidade de Caldas (Colombia) (Janeiro de1999 - Abrilde 2008) Efecto de extractos vegetales sobre huevos y larvas de Meloidogyne spp. Cursos de corta duração "Sociedad Colombiana De Fitomejoramiento Y Producción De Cultivos" Resistencia a Factores Bióticos y Abióticos (Junho de 2010 - Junho de 2010) Universidad de los Andes Biología (Agostode2011 - Agostode 2011)

\section{LUIZ PAULO CAMPOS PATRÍCIO}

Graduando em Engenharia Agronômica pela Universidade Federal do Recôncavo da Bahia. Tem experiência na área de Recursos genétocos vegetais e Morfologia de solos

\section{MAGALE KARINE DIEL RAMBO}

Possui graduação em Química Licenciatura pela Universidade Federal de Santa Maria (2007), mestrado em Química pela Universidade Federal de Santa Maria (2009) e doutorado em Química pela Universidade Estadual de Campinas (2013). Realizou estágio no grupo Carbolea da Universidade de Limerick (UL), Irlanda, participando do projeto DIBANET (www.dibanet.org) entre a Comunidade Européia e a América Latina. Atualmente é pesquisadora de produtividade pela Universidade Federal do Tocantins (UFT) e Professora do Curso de Engenharia Ambiental e do Programa de Pós-Graduação em Ciências Ambientais da UFT . Tem experiência na área de Química Analítica, com ênfase em Química Analítica Ambiental, Biocombustíveis, Biorrefinarias e Quimiometria.

\section{MARCELINO GEVILBERGUE VIANA}

Biólogo com doutorado em Biotecnologia pela Universidade Federal do Rio Grande do Norte UFRN. Atualmente é professor temporário no curso de Enfermagem da Universidade Regional do Cariri - URCA. Tenha ampla experiência em Microbiologia e Microbiologia Ambiental com ênfase em Biofilmes microbianos e Biocidas naturais bem como em Química Verde.

\section{MARCELO AUGUSTO DA SILVA SOARES}

Engenheiro agrônomo formado pela Universidade Federal de Alagoas (UFAL) pós-graduado em Engenharia de Segurança do Trabalho (UNIFAL) com mestrado em Agronomia - Produção Vegetal (UFAL) e atualmente doutorando em Agronomia na área de concentração em Produção Vegetal (UFAL).

\section{MARCELO MARINHO VIANA}

Possui graduação em Engenharia Agronômica pela Universidade Estadual do Maranhão/Campus Paulo VI (2014), Mestre em Agroecologia pela Universidade Estadual do Maranhão (2017). Atualmente discente no Programa de Pós-Graduação em Agroecologia/Universidade Estadual do Maranhão, nível Doutorado. Tem experiência na área de agronomia, com ênfase na linha de pesquisa sobre sistemas de produção agroecológicos: Nutrição de plantas, Eficiência do uso do 
nitrogênio, Fisiologia do crescimento vegetal, Bactérias endofíticas, Promoção de Crescimento Vegetal, Fixação Biológica de Nitrogênio em não-leguminosas.

\section{MARIA LÚCIA DA SILVA CORDEIRO}

Possui graduação em Engenharia de Biotecnologia e Bioprocessos pela Universidade Federal de Campina Grande (2015), tendo atuado principalmente nas áreas de Microbiologia, Fitopatologia e Biotecnologia Ambiental. Mestre em Bioquímica pela Universidade Federal do Rio Grande do Norte (2018), com experiência em estudos de atividade farmacológica e caracterização fitoquímica de plantas medicinais.

\section{MARIA ZILDERLANIA ALVES}

Possui graduação em Engenharia Agronômica pela Universidade Federal Rural do Semi-Árido (2000). Mestrado em Agronomia: Fitotecnia pela Universidade Federal Rural do Semi-Árido (2003). Doutora em Fitopatologia pela Universidade Federal Rural de Pernambuco (2009). Atualmente é professora Associada I da Universidade Federal Rural de Pernambuco, com lotação na Unidade Acadêmica de Serra Talhada. Atua na área de Epidemiologia em doenças pós colheita, Manejo fitossanitário e microbiologia geral; e áreas afins como Grandes Cultivos e Metodologia da Pesquisa Cientifica.

\section{MARIANA COSTA RAMPAZZO}

Engenheira Agrônoma, Mestra em Agronomia pela Universidade Estadual do Sudoeste da Bahia. Foi Bolsista de Iniciação Científica (CNPq/PIBIC - 2013 a 2016) no Laboratório de Melhoramento vegetal, participando de pesquisas referentes à cultura da mandioca. Durante o mestrado (20172018) desenvolveu o trabalho de interferência de plantas daninhas no feijão-caupi (Vigna unguiculata (L.) Walp), vinculado ao laboratório de Biotecnologia. Atualmente é discente do Doutorado do Programa de Pós-Graduação em Agronomia da Universidade Estadual do Sudoeste da Bahia, com pesquisa em desenvolvimento sobre manejos de materiais de plantio de mandioca.

\section{MICHELLE DE OLIVEIRA GUIMARÃES-BRASIL}

Possui graduação em Agronomia pela Universidade Federal do Ceará (2008), mestrado (2011) e doutorado (2015) em Zootecnia, com área de concentração em Abelhas e Polinização, pela Universidade Federal do Ceará (UFC). Tem experiência na área de Agronomia, atuando nas áreas de Apicultura, Meliponicultura, Abelhas Solitárias e Polinização de Culturas Agrícolas. Atualmente é professora do Instituto Federal de Educação, Ciência e Tecnologia do Rio Grande do Norte no Campus de Pau dos Ferros.

\section{MONIZY DA COSTA SILVA}

Professora de Química da rede estadual do Estado de Alagoas. Doutoranda em Química e Biotecnologia, pela Universidade Federal de Alagoas- UFAL. Mestre em Química e Biotecnologia, com ênfase em Bioquímica de macromoléculas (UFAL). Trabalho com purificação e caracterização de proteínas com utilizações biotecnológicas (utilizações em setores industriais e na área da saúde). Especialista em Bioquímica e Biologia Molecular pela Faculdade de Ensino Regional- FERA. Graduada em Química-Licenciatura pela Universidade Estadual de Alagoas- UNEAL.

\section{NAAMA AGUIAR MOREIRA}

Graduanda do curso de Engenharia Florestal pela Universidade Estadual da Região Tocantina do Maranhão - UEMASUL 


\section{NELSON CEBALLO AGUIRRE}

Doctorado UNIVERSIDAD DE CALDAS Doctorado en Ciencias Agrarias Juliode2009 - Diciembrede 2012 EVALUACIÓN AGRONÓMICA, MOLECULAR E INTERACCIÓN GENOTIPO AMBIENTE DE INTRODUCCIONES DE TOMATE TIPO CEREZA Pregrado/Universitario UNIVERSIDAD DE CALDAS Ingeniero Agronomo Agostode1998 - Agostode 2004 Optimización de la micropropagación del plátano Dominico Hartón Mussa balbisiana colla genoma AABB Formación Complementaria Cursos de corta duración UNIVERSIDAD DE CALDAS Diplomado En Competencias de La Educación Superior Enerode2006 - de 2006 Cursos de corta duración UNIVERSIDAD DE CALDAS Diplomado En Competencias de La Educación Superior Enerode2005 - de 2005 Cursos de corta duración UNIVERSIDAD DE CALDAS Diseño experimental Enerode2006 - de 2006 Cursos de corta duración UNIVERSIDAD DE CALDAS Diseño experimental Enerode2001 - de 2001 Cursos de corta duración Centro Auxiliar De Servicios Docentes Operador de Sistemas Enerode 1998 - de 1998 Cursos de corta duración UNIVERSIDAD DE CALDAS Hidraulica Enerode2005 - de 2005 Cursos de corta duración UNIVERSIDAD DE CALDAS Hidraulica Enerode2005 - de 2005 Cursos de corta duración Manejo integrado del tomate (L.esculentum) en el e Enerode2005 - de 2005 Cursos de corta duración UNIVERSIDAD DE CALDAS Hidraulica Enerode2001 - de 2001

\section{ODEANE VIRIATO MAIA}

Possui graduação em Agroecologia pela Universidade Federal do Recôncavo da Bahia (2018). Tem experiência na área de Agronomia com base sustentável, com ênfase em manejo e conservação do solo, além de atuar como facilitador de abertura de mercado para agricultores familiares através das diretrizes que regem a agroecologia

\section{OSVALDO NOGUEIRA DE SOUSA NETO}

Engenheiro Agrônomo; Doutor em Ciências; Professor do Magistério Superior, Departamento de Engenharias, Universidade Federal Rural do Semi-Árido - UFERSA, Angicos, RN.

\section{PATRICIA OLIVEIRA VELLANO}

Possui graduação em Farmacêutica bioquímica pelo Instituto Unificado de Ensino Superior Objetivo (1994).Pós graduada em Farmácia Hospitalar e Farmácia clinica e mestre em Ciência e Tecnologia de Alimentos pela Universidade Federal do Tocantins. Exerci o cargo de professora no UNITPAC sendo responsáveis pelas cadeiras de estagio supervisionado I, II e III do curso de Farmácia Generalista. Tutora do curso de Farmácia UNOPAR. Farmacêutica Hospitalar do Hospital Regional de Araguaína.

\section{PEDRO RAMUALYSON FERNANDES SAMPAIO}

Agrônomo; Doutor em Ciências, Departamento de Engenharia de Biossistemas, Escola Superior de Agricultura Luiz de Queiroz / Universidade de São Paulo, Piracicaba, SP.

\section{POLYANA MORAIS DE MELO}

Mestre em Ciência e Tecnologia de Alimentos, atuando na linha de pesquisa de Biotecnologia aplicado a Indústria de Alimentos pela Universidade Federal do Tocantins (Atualmente). Especialização em Engenharia de Segurança do Trabalho pela Instituição Galileo (2016). Graduação em Engenharia de Alimentos pela Universidade Federal do Maranhão (2016). Bolsista do PET( Programa de Educação Tutorial ) - Conexões de Saberes (2012) e bolsista do PIBIC no grupo de pesquisa NUPFARQ (Núcleo de Ciências Farmacêuticas e Química Analítica Aplicada), atuando como pesquisadora no desenvolvimento e validação de métodos analíticos para a determinação de espécies químicas de interesse farmacêutico, agroindustrial, ambiental, tecnológico e alimentício, com ênfase em Controle de Qualidade Físico-Químico de Medicamentos e Alimentos (2015). 


\section{RAFAEL DE AGUIAR RODRIGUES}

Formado em Engenharia Florestal Pela Universidade Federal do Oeste do Pará (UFOPA), tem com principal linha de pesquisa a anatomia da madeira, suas bases biológicas e sua relação com as propriedades tecnológicas da madeira. Tem exercido atividades de consultoria em caracterização tecnológica e identificação de madeiras amazônicas em parceria como o Laboratório de Tecnologia da madeira da UFOPA. Atualmente é pós graduando na ESALQ/USP, com o tema de mestrado "Colagem de painéis MLC com madeiras amazônicas e sua viabilidade frente à madeira sólida".

\section{RANOEL JOSÉ DE SOUSA GONÇALVES}

Engenheiro Agrônomo pela Universidade Federal Rural do Semi-Árido - UFERSA. Mestre em Genética e Melhoramento de Plantas pela Universidade Federal de Lavras - UFLA, onde atuou nos seguintes temas: Melhoramento de plantas e Genética quantitativa com ênfase no Melhoramento Genético do feijoeiro (Phaseolus vulgaris). Doutor em Genética e Melhoramento de Plantas -UFLA. Atuando na área de Melhoramento Genético de hortaliças. Atualmente é Professor Associado da Universidade Federal de Campina Grande, com lotação na Unidade Acadêmica de Tecnologia do Desenvolvimento (UATEC), Campus Sume-PB.

\section{RENATA RANIELLY PEDROZA CRUZ}

Engenheira Agrônoma pela Universidade Federal da Paraíba - UFPB, Campus Areia e Mestre em Fitotecnia pela Universidade Federal de Viçosa - UFV. Atuação na área de ecologia, com trabalhos na área de ecofisiologia de plantas cultivadas e nativas; e atualmente, tem trabalhado na área de fisiologia e pós-colheita de hortaliças.

\section{RENNAN DA SILVA DE SOUSA MOREIRA}

Graduando do curso de Engenharia florestal, na universidade Estadual da Região Tocantina do Maranhão - UEMASUL. Bolsista no projeto AVALIAÇÃO DO ESTADO NUTRICIONAL DO BABAÇU PARA O ESTADO DO MARANHÃO " foi contemplado no EDITAL FAPEMA № 028/2018 - IECT BABAÇU - BESTI2 - BOLSA DE ESTÁGIO EM INOVAÇÃO 2, sob a orientação do Prof.(a) Dra. ANATERCIA FERREIRA ALVES, da Fundação de Amparo à Pesquisa e ao Desenvolvimento Científico e Tecnológico do Maranhão - FAPEMA, no período de 01/01/2019 até 30/12/2019. Voluntário no projeto de pesquisa universal /FAPEMA, edital 03/2016, intitulado "Estrutura da comunidade entomofaunística (Himenópteros solitários, Dipteros Necrófagos, odonatas, Heteropteras e coleopteras) em diferentes sistemas de pastagens no oeste maranhense: Implicações para a conservação e Biodiversidade", no período de janeiro a junho de 2018.

\section{RICARDO BARBOSA GOMES DE MORAIS}

Engenheiro agrônomo formado pela Universidade Federal de Alagoas (UFAL) com mestrado em Energia de Biomassa (UFAL).

\section{RITA DE CÁSSIA SANTOS NUNES}

Possui graduação em Agronomia e mestrado em Zootecnia, ambos pela Universidade Estadual do Sudoeste da Bahia . Atualmente é Analista Universitária na Universidade Estadual do Sudoeste da Bahia. Tem experiência na área de Fitotecnia pela atuação nas atividades de pesquisa e gestão de campo com as quais trabalha na instituição, e em Zootecnia, pelas atividades desenvolvidas em Comportamento Reprodutivo Animal.

\section{SERGIO NASCIMENTO DUARTE}

Engenheiro Agrônomo, Mestre em Irrigação e Drenagem pela ESALQ/USP (1989) e Doutor em Engenharia Agrícola pela UFV (1996). Atualmente é Prof. Associado 2 do Depto. de Engenharia de Biossistemas na ESALQ/USP, em Piracicaba - SP. 


\section{TIMÓTEO HERCULINO DA SILVA BARROS}

Engenheiro Agrônomo; Doutor em Ciências, Departamento de Engenharia de Biossistemas, Escola Superior de Agricultura Luiz de Queiroz / Universidade de São Paulo, Piracicaba, SP.

\section{VIVIANE AMARAL TOLEDO COELHO}

Possui graduação em Ciências Biológicas pelo Centro de Ensino Superior de Juiz de Fora (2006), mestrado em Ciência do Solo pela Universidade Federal de Lavras (2011) e doutorado em Ciência do Solo pela Universidade Federal de Lavras (2015) com parte dele realizado na University of Queensland, na Austrália. Atualmente é professora de Ciências da Natureza e Educação Integral de educação básica da Escola Estadual Conde Afonso Celso, professora de Ciências, Educação para Cidadania e Projeto de Vida na Escola Estadual Conde Afonso Celso e professora da Faculdade ALFA em vários Cursos.

\section{YACENIA MORILLO CORONADO}

Ingeniera Agrónoma, con doctorado en Mejoramiento Genético de Plantas de la Universidad Nacional de Colombia, Sede Palmira. Ha trabajado como docente en la Universidad Francisco de Paula Santander, la Universidad de los Llanos y en la Universidad de Caldas en el área de Fitomejoramiento y Biotecnología Vegetal. Actualmente es Investigador Ph.D., del Centro de Investigación Palmira de la Corporación Colombiana de Investigación Agropecuaria - AGROSAVIA. Ha participado en diversos trabajos de investigación en el área de Biología Molecular, sobre todo en el uso de marcadores moleculares para estudios de diversidad genética en cultivos como mora, cítricos, palma de aceite, cacao, tomate, entre otros. Ha liderado proyectos de investigación y dirigido tesis de grado a nivel de pregrado y posgrado en el área de mejoramiento genético y producción de cultivos.

\section{YARA KARLA DE SALLES NEMET}

Possui graduação em Biomedicina, licenciatura em Química, especialista em Saúde Pública pela Universidade Federal do Tocantins (UFT), e Mestre em Ciência e Tecnologia de Alimentos pela UFT. Atua como biomédica no HEMOCENTRO COORDENADOR DE PALMAS no setor de sorologia. Já atuei como preceptora de Estágio Supervisionado do Curso Técnico de Hemoterapia na Escola Tocantinense do Sistema Único de Saúde (ETSUS) e como professora do Ensino Fundamental. 
